\title{
Systematic studies in Cyperus section Pinnati (Cyperaceae)
}

\author{
Karen L. Wilson
}

\begin{abstract}
Wilson, Karen L. (National Herbarium of New South Wales, Sydney, NSW Australia 2000) 1991. Systematic studies in Cyperus section Pinnati (Cyperaceae). Telopea 4(3): 361-496. The limits of Cyperus section Pinnati Kük. are extended to include thirty-two species (with ten subspecies). C. astartodes, C. blakeanus, C. centralis, C. cracens, C. crispulus, C. fucosus, C. hesperius, C. isabellinus, C. latzii, C. orgadophilus and C. secubans are described as new species. New subspecies are described in C. cunninghamii (subsp. cheradicus and subsp. uniflorus), C. microcephalus (subsp. chersophilus and subsp. saxicola), and C. betchei (subsp. commiscens), while C. gunnii subsp. novaehollandiae is proposed as a new combination. Two keys (one dichotomous bracketed, one multientry) to the species are provided. Gross morphology, vegetative and nut epidermal anatomy, and phytochemical features are discussed. and used to distinguish species within the Section and also to distinguish this Section within Cyperus sens. lat. The unusual leaf anatomy (Metcalfe's Mariscus A-type) is shared with species in the related sections Glutinosi, Thunbergiani and Turgiduli. This is the only Section endemic to Australasia: the species are mostly confined to Australia but three extend to southern New Guinea and a few species have been recorded as naturalised in New Zealand and Europe. Section Pinnati is of phytogeographic interest since it is probably most closely related to section Glutinosi of the Americas and the islands of the eastern Pacific and Caribbean.
\end{abstract}

\section{Contents}

Introduction $\quad 362$

Materials 363

Definition and discussion of characters 363

$\begin{array}{ll}\text { Vegetative characters } & 363\end{array}$

Inflorescence characters $\quad 367$

SEM study of the nut epidermis $\quad 372$

$\begin{array}{ll}\text { Vegetative anatomy } & 378\end{array}$

$\begin{array}{ll}\text { Phytochemistry } & 389\end{array}$

Photosynthetic types $\quad 391$

Distribution and ecology 391

Distribution $\quad 391$

Ecology $\quad 392$

Taxonomy $\quad 393$

Taxonomic history $\quad 393$

Relationships $\quad 396$

Formal taxonomy $\quad 400$

$\begin{array}{ll}\text { Keys to species } & 401\end{array}$

Description of species $\quad 412$

$\begin{array}{ll}\text { Excluded name } & 488\end{array}$

$\begin{array}{ll}\text { Acknowledgments } & 488\end{array}$

$\begin{array}{ll}\text { References } & 489\end{array}$

Index $\quad 493$ 
'This section was erected by Kükenthal to include a most difficult series of endemic Australian forms. Though placed by the author in the subgenus Mariscus the first three species enumerated (C. angustatus $\mathrm{R}$. Br., C. dactylotes Benth., and C. gilesii Benth.) are typical Eucyperus in structure, while most of the other species combine the characters of both subgenera as described above for C. subulatus. Kükenthal's arrangement of the forms and his key to them is very unsatisfactory, and what follows can be regarded merely as some contribution towards a better understanding of this most difficult group.' - Blake (1940: 42)

\section{Introduction}

Cyperus sens. lat. includes most (about 700) of the species in tribe Cypereae. Taken in this broad sense, the genus shows considerable variation and numerous attempts have been made to subdivide it, whether recognising the subdivisions at subgeneric level (e.g. Kükenthal 1935-36, Haines \& Lye 1983, Tucker 1983) or as distinct genera (e.g. Raynal 1973). Taxa traditionally recognised include Cyperus L. sens. strict., Kyllinga Rottb., Mariscus Gaertn., Pycreus P. Beauv., Remirea Aubl. and Torulinium Desv. Characters used to distinguish these subdivisions have included type of dispersal unit (individual flowers, or whole spikelet, or corky segments of rachilla plus associated flower); number of style branches; nut shape and orientation; the number of flowers per spikelet. Récent treatments have also used Kranz versus non-Kranz vegetative anatomy (taken as an indicator of $\mathrm{C}_{4}$ photosynthesis) to distinguish subgroups.

My interest in Cyperus section Pinnati began about twelve years ago when, in collaboration with L.A.S. Johnson, I began a critical examination of generic limits in tribe Cypereae. Results of that study have not been published because we were not satisfied with the placement of various problem groups of species, including section Pinnati. This Section and a few others, especially sections Glutinosi and Laxiglumi, blur the boundaries between Cyperus sens. strict. and Mariscus. I believe that these traditional groups should be re-classified on the basis of Kranz/non-Kranz anatomy and other characters such as the arrangement of spikelets in the partial inflorescences either digitately or spicately, to give two main groups (either as genera or subgenera): Cyperus sens. strict. (including Mariscus) and Anosporum (the $\mathrm{C}_{3}$ species; at subgeneric level, this would be known as subgen. Anosporum (Nees) C.B. Clarke (Goetghebeur 1989)).

Sect. Pinnati is the only group in Cyperus sens. lat. endemic to Australasia. It is of phytogeographic interest since it is probably most closely related to the mainly American section Glutinosi (found in North, Central and South America, and islands of the eastern Pacific and Caribbean). Kükenthal (1935-36) erected the section Pinnati for a group of ten Australian species, based on various characters, including short rhizomes, narrow or absent rachilla wings, hemispherical and rather loose partial inflorescences (clusters of spikelets), persistent glumes, and glumes more or less remote and spreading so as to give a pinnate appearance to mature spikelets. Some of the taxonomic problems and confusion in section Pinnati are alluded to by Blake in the quotation above and by Domin (1915: 443-444).

Only limited material was available for earlier taxonomic studies. The few temperate species were mostly well-collected and well-defined by this century. However, the main concentrations of species are in the arid zone and the tropical monsoonal region with alternating wet and dry seasons ('wet/dry tropics') where extensive field work has become possible only recently. In the present study, gross morphological and 
anatomical characters are used to re-define the Section. It is extended to include six species placed by Kükenthal in other Sections, as well as three species described by Blake $(1940,1947 a)$, two by Wilson (1980), and eleven new species proposed here. Ten subspecies are recognised, in species where variation is geographically related.

It should be noted that, unless otherwise indicated, sectional names used here are as given in Kükenthal (1935-36) to facilitate reference to that work, which is the most recent complete revision of Cyperus sens. lat. Some names are not the earliest available (see below).

\section{Materials}

The study is largely based on the herbarium collections held at NSW, which have been greatly augmented in recent years by exchange specimens from other herbaria and individual collectors, notably Mr A.C. Beauglehole of Victoria (his herbarium is cited as ' $\mathrm{ACB}$ ').

Specimens in other herbaria have been examined in situ or on loan, through the courtesy of the curators of: AD, B, BM, BRI, C, CANB, CGE, CHR, DBN, DNA, E, G, HO, JCT, K, KIEL, L, MEL, MO, NE, NT, NY, P, PERTH, PRE, SYD, TCD, UNSW, US. No more than twenty specimens per taxon have been cited: in some cases, I have seen over 100 specimens of a taxon, in others only about ten. A complete list is in the library of the Royal Botanic Gardens; requests for copies should be addressed to the Librarian. Collectors' names are given as surnames only, except for types and where there might be confusion ('Wilson' refers to the author).

Field studies have been very important in understanding habitat differences and the morphological variation within a species, data often very inadequately represented on herbarium specimens. I have undertaken extensive fieldwork in eastern, central and northern parts of Australia, but I have not visited the Pilbara and western Kimberley of Western Australia, or Cape York, Queensland.

\section{Definition and discussion of characters}

\section{Vegetative characters}

\section{Habit}

The majority of species in section Pinnati are tufted, some rooted shallowly, others deeply. A few of these tufted species are annuals or short-lived perennials (e.g. C. gilesii and C. rigidellus), while others are obviously perennial, forming big tussocks (e.g. C. alterniflorus and C. gunnii). Some seem to be facultatively annual, depending on environmental factors, especially availability of moisture and occurrence of fire (e.g. C. dactylotes, $C$. holoschoenus and C. latzii). Growth and habitat conditions are such that the morphology of these species can vary widely over time or between microhabitats within the same population, to the extent that two 'varieties' (as previously recognised) can be found on the one plant (see, for example, Blake's comments under C. fulous).

Bulbously thickened culm-bases occur in C. orgadophilus, C. sexflorus and C. sporobolus; the bases are somewhat bulbously thickened in C. blakeanus and C. centralis, rarely so in C. fulvus. Unlike the majority of species of Cyperaceae, these six occur in dry-land habitats where soil water would be low for much of the year and fires would be relatively frequent and regular (at least in the tropical savannas in which the first 
three species grow, and perhaps also in the arid and semi-arid regions in which the last three species are found).

Large tussock-forming and bulbous-based species frequently produce surculi (defined by Haines and Lye (1983) as new shoots, formed in the axils of lower leaves, that break through the leaf sheath to become extravaginal and then grow horizontally for a short distance before growing vertically). These allow limited vegetative spread. The difference between surculi and short rhizomes is one of degree rather than any fundamental distinction. The larger tufted or tussocky species could be termed either very shortly rhizomatous or surculose, but I have described them as tufted or tussocky on the understanding that such species mostly produce surculi to achieve the large tuft or tussock form.

The only distinctly rhizomatous species is C. angustatus, which has a long, delicate rhizome. The rhizomes are frequently broken off in herbarium specimens but remnants can usually be found amongst the fibrous roots. C. lhotskyanus is usually shortly rhizomatous or long-surculose, but occasionally tufted. Solitary culms broken off just above the root-level are also an indicator of these two species: if these plants are ripped from the soil rather than carefully dug up, the culms usually break off at ground level. In the more tufted species, at least portion of the root system remains with the culm. In the field, this is a useful characteristic for distinguishing C. Ihotskyanus and C. gunnii, which often grow together.

A few species are characteristically viscid, particularly $C$. ixiocarpus and C. cunninghamii, which are viscid about the spikelets and along the leaves and culms when they are carrying mature inflorescences. C. viscidulus is less copiously viscid, and only so about the spikelets. $C$. rigidellus and $C$. fulous occasionally have viscid spikelets, while C. alterniflorus may have viscid leaf bases. Rarely, some other species are viscid. I observed no obvious glands or other secretory regions, externally or microscopically in my (limited) sectioning of spikelets, like those reported by Burbidge (1946) in Triodia pungens and by Dell \& McComb (1978) in various groups (mainly dicots and gymnosperms).

\section{Culms}

The overall height (i.e. culm plus inflorescence length) of the plant is given in the descriptions. A range is given for each taxon but it is frequently possible to find stunted individuals that fall below that range if one collects from a habitat extreme, say, the dry-land margin of a river-bank or a particularly shallow soil-pocket on a rocky outcrop. Culm diameter has been measured about halfway between apex and base. The culm cross-sectional shape varies from trigonous to terete or triquetrous, even within a species. The culm is more or less solid and without aerial nodes, hence the clustering of leaves at the base.

The culm surface is smooth in many species, but it is scabrous, at least near the apex, in some, hotably C. microcephalus subsp. microcephalus, C. portae-tartari and C. perangustus. Others, such as $C$. fulvus and C. gunnii, have the culms occasionally scabrous.

The colour of the culms and other vegetative parts is a useful distinguishing feature in the field but virtually useless in the herbarium as all species fade greatly on drying. Since I have not observed all species in the field, notes on colour of vegetative parts are incomplete. Many species are yellowish green, corresponding to the darker tones of colour numbers 143 and 144 ('Grass Green' and 'Lettuce Green') of the Royal Horticultural Society colour chart. The range of colours is not great but can be useful in some cases, e.g. in distinguishing $C$. carinatus (blue-green) from $C$. holoschoenus (yellow-green). 


\section{Leaves}

Most species have more or less evenly suberect spreading leaves. However, they are recurved at maturity in, for example, $C$. sporobolus and are strongly curled to circinnate towards the apex in C. crispulus, C. rigidellus, C. secubans and C. microcephalus subspp. chersophilus and saxicola (and occasionally so in C. fulous).

Leaf laminas (and less commonly the sheaths) may be septate-nodulose, i.e. they have short transverse internal septa. This is most obvious in the more robust species and is generally only observable in dried specimens, when the tissues have shrunk around the septa.

Leaf length is too variable to be diagnostically useful. Leaves range from about half the length of the culms to somewhat exceeding them.

Leaf lamina width and shape in cross-section were examined at a point about halfway between the apex and the top of the sheath. Leaves all taper to a point and become triangular in cross-section near the apex. Most species have a scabrous midrib abaxially near the apex, even those that become canaliculate lower down the leaf. Developmental stage is important since the leaves in most species are more or less crescentiform when immature. Hence, these characters have been examined on the most mature complete leaf (i.e., fully elongated but not senescent) on a specimen.

Cross-sectional shape of the lamina varies considerably between species (see also page 379). Shape is strongly influenced by the degree of development of the midrib and the presence or absence adaxially of bulliform cells (most easily observed microscopically in cross-section). Many species have no obvious midrib except near the apex and are canaliculate (corresponding to the anatomical term 'crescentiform'). Leaf shape in cross-section is often at least slightly asymmetrical, more markedly so in those leaves without obvious midrib. In other species there is an obvious midrib on the abaxial surface of the lamina, often developed into a keel, and these leaves have been termed 'flat' or 'carinate' depending on the degree of lateral folding of the leaf. Anatomically, both terms are included in 'V-shaped'. When obvious abaxially, the midrib is mostly smooth at the halfway point, but it is scabrous in some species (e.g. C. alterniflorus, C. microcephalus subsp. microcephalus, C. oxycarpus, C. portae-tartari), and may be scabrous near the apex in all species. The abaxial surface is occasionally more generally scabrous, whether or not there is an obvious midrib (e.g. in C. cunninghamii).

A hypodermis is present beneath the adaxial epidermis in all species. This is reflected in the texture of the adaxial surface, which is often somewhat 'spongy' and is uniformly smooth and whitish in most species, with the outlines of the large epidermal cells seen as a reticulate pattern with a hand lens. The leaves of many species are relatively thick (e.g. C. ixiocarpus); others have thin and grass-like leaves (e.g. C. isabellinus). Some species have lateral nerves visible adaxially, e.g. C. alterniflorus, C. isabellinus, $C$. Ihotskyanus and $C$. portae-tartari. These nerves may be caused by prominent vascular bundles or by small sclerenchyma strands beneath the adaxial epidermis. In contrast, small bundles may occasionally be present without producing visible nerves (e.g. in C. carinatus and C. microcephalus subsp. saxicola).

The leaves (and inflorescence bracts) of all species have colourless, usually minute, silicified projections from marginal cells (and often from the midrib of the abaxial surface as well). Metcalfe (1971) calls such projections prickles or prickle hairs. These prickles are denser and more obvious towards the apex of the leaf or bract. Towards the base of the lamina they are much sparser or even absent. In C. holoschoenus, for example, there are often no prickles except in the uppermost quarter of the leaf. My standard examination point for this character was the uppermost quarter to third of 
the leaf. Being nearly transparent, the prickles are best viewed with a dissecting microscope against a dark background. The prickles are here characterised (Figure 1) in terms of:

(i) density. This takes into account the regularity of spacing as well as actual distance between prickles. The impression of density is influenced by the length and direction of the prickles (see (iii) and (iv) below). The categories used are: dense, when the spacing between prickles is $\leq 0.5 \mathrm{~mm}$ and fairly regular - in general, the distance between prickles in this category is no more than one and a half times the length of the prickles; sparse, when the spacing is generally $0.6-1.5 \mathrm{~mm}$, although it may be as low as $0.1 \mathrm{~mm}$ in irregularly spaced specimens; very sparse, spacing greater than $1.5 \mathrm{~mm}$.

(ii) regularity: regularly or irregularly spaced.

(iii) length: very short, less than $0.05 \mathrm{~mm}$ long - only seen in C. hesperius, C. microcephalus, $C$. crispulus and $C$. viscidulus; short, $0.05-0.1 \mathrm{~mm}$ long - all taxa may have prickles in this category; long, more than $0.1 \mathrm{~mm}$ long - the longest prickles, about 0.7 $\mathrm{mm}$, were found in specimens of $C$. fulvus.

(iv) direction: antrorse, that is, directed towards the leaf or bract apex; erect, at 90 degrees to the margin; retrorse, directed towards the base of the leaf or bract; flabellate, aculeate or papillate prickles clustered in a fan-shape, that is, spreading in two dimensions.

(v) form: aculeate, prickles acutely pointed; or papillate, prickles obtuse-topped or rounded at the apex.

Taxa have a characteristic form of prickle, although there is some variation within C. alterniflorus, $C$. carinatus and C. fulvus. Most species have antrorsely aculeate prickles, which differ in density, length and regularity. Some have papillate prickles, either simple and erect, as in C. gilesii and C. rigidellus, or flabellate as in many

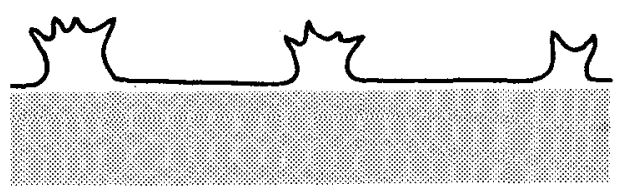

a

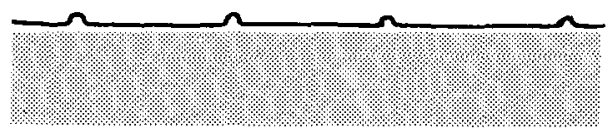

b

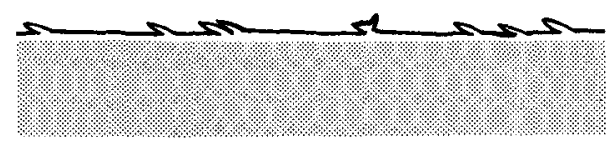

C

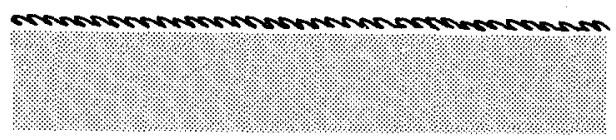

d

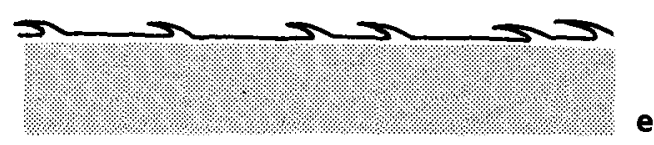

Figure 1. Marginal prickles on leaves and bracts (apex of leaf or bract to the left), X 20. a, Flabellate; b, papillate; $\mathbf{c}$, mixed types, as seen in C. lhotskyanus; d, antrorsely aculeate (dense and short in this example); $\mathbf{e}$, antrorsely aculeate (sparse and long). 
specimens of $C$. fulvus. A few species have mixed types of prickles on the same leaf: C. carinatus has both papillate and aculeate prickles; C. blakeanus, C. latzii and C. lhotskyanus have simple aculeate prickles (a mixture of antrorse, erect and retrorse) as well as flabellate aculeate prickles.

Leaf sheaths are generally closed in species of Cyperaceae but in this group of species, as in many others, mature outer sheaths tend to rip open as more leaves, and ultimately an inflorescence-bearing culm, are produced within them from the basal meristem. The length of the closed portion of the sheath may be as little as $1 \mathrm{~cm}$, in C. clarus and C. fulvus, or as much as $7 \mathrm{~cm}$, in C. gunnii. The sheath includes a thinnertextured, often more or less hyaline, zone opposite the lamina, extending the length of the sheath and about one third of its circumference. This thin fragile zone is only obvious in young leaves and is readily torn as the plant grows.

The thicker-textured portion of the sheath is longitudinally striate and/or septatenodulose in some species, whereas in others the surface is smooth and shining. These features are recorded for all species. Sheath texture varies from similar to that of the leaf lamina to thin and membranous. The general texture has not been included in most descriptions. Similarly, the texture of the sheath margins (i.e. the remnants of the torn zone) is not generally mentioned. They are most prominent in C. cunninghamii, which has broad white membranous margins. Sheath colour is reasonably consistent for a species, although the sheaths of plants in standing water tend to become dark brown or black. The colour of the internal (adaxial) surface of the sheath is generally similar to the external surface.

The number of photosynthesising leaves (that is, excluding old dried-up leaves) associated with each culm varies between about four and ten. Each species seems to have a characteristic range (e.g. C. alterniflorus, C. gunnii and C. Ihotskyanus have 4-6 leaves per culm, C. fulvus has 8-10, C. clarus has 5-9).

\section{Inflorescence characters}

As is often the case, the relative constancy intraspecifically of features of the inflorescence and flowers makes them the major source of diagnostic and descriptive characters.

The inflorescence in Cyperus has been called an anthela (Kükenthal 1935-36), which is a variant of the corymb, differing from that in having the main axis shorter than the laterals, and with lateral axes of unequal length, thereby forming a funnel-shaped inflorescence as found in certain Rosaceae (Krasan 1864, Troll 1964). However, it is inappropriate to use the term anthela in this case since the inflorescence in Cyperus has the main axis ending not in a flower (as is found in corymbs) but in an open spikelet, that is, it is blastotelic and anauxotelic in Briggs \& Johnson's terminology (Briggs \& Johnson 1979) or polytelic in Troll's terminology (Troll 1964, Weberling 1989). Troll (1964: 63) had recognised this and foreshadowed his intention to introduce the term anthelodium for the 'spirrenartigen Infloreszenzen der Juncaceen und gewisser Cyperaceen' but never did so.

Whatever the appropriate name may be, the inflorescence in all species of section Pinnati is basically funnel-shaped in form, the longest branches being the lowest. At the base of each branch (above the subtending bract) is a tubular prophyll, the form of which varies little. Other features dealt with below are of more interest diagnostically. 


\section{Involucral bracts}

At the base of the inflorescence in Cyperus there is usually an apparent whorl of leaflike elongate involucral bracts. It is not a true whorl but rather a closely packed ascending sequence of involucral bracts, each bract subtending an inflorescence branch ('ray' of many authors). This is more obvious in species of Cyperus section Tunicati (e.g. C. bulbosus Vahl) in which the bracts are widely separated. Rarely, widely spaced bracts are present in species of section Pinnati, for example one specimen of $C$. blakeanus (Wilson 3573) has the lowest bract and branch separated by about $2 \mathrm{~cm}$ from the rest of the inflorescence. Anatomically and morphologically, the bracts appear homologous with the leaf lamina.

In section Pinnati, each species has a more or less constant number of involucral bracts that exceed the inflorescence and are held either erect or spreading. The majority of species have 2-4 such bracts but some species have only 1 or 2 (e.g. C. angustatus, C. cracens and C. crispulus) while a few have more (up to 8 in C. portaetartari). In absolute terms, these bracts can be as long as $65 \mathrm{~cm}$ (in C. gunnii); relatively, they can be longer than the length of the culms, notably in C. microcephalus subsp. saxicola. The marginal prickles may be more densely packed than on the leaves.

Occasionally the small leafy bracts at the base of the individual spikelet clusters are obvious and reflexed, giving a characteristic appearance to those species (especially C. perangustus and C. sporobolus).

\section{Inflorescence branching}

The inflorescence is termed simple, compound or decompound depending on the order of branching present. Thus, where the spikelets are clustered at the apex of the primary branches the inflorescence is described as simple; where the primary branches bear a set of secondary branches that have the spikelets clustered at their apices, the inflorescence is compound. Inflorescences are termed small-compound if they have only a few short secondary branches, mostly no more than $2 \mathrm{~cm}$ long and always much shorter than the primary branches. Higher orders of branching occur: the maximum is quaternary branching in $C$. portae-tartari. Rarely, the inflorescence is reduced to a superficially head-like cluster (e.g. in C. rigidellus) but even then short branches are always present. Species generally exhibit one order of branching, but luxuriant or depauperate specimens of a species may have one order more or less than is usual.

The size of the inflorescence is described quantitatively in terms of the number and length of primary branches over $1 \mathrm{~cm}$ in length. In some cases there are also some shorter branches crowded together below the terminal spikelet but the congestion is too great for easy counting.

The parenchymatic swelling found at the base of branches and individual spikelets in Cyperus spp. appears to have the same function as a pulvinus or grass lodicules (Holm 1904) in spreading the relevant part relative to the axis (always permanently in this case). In sect. Pinnati, the branches and spikelets usually abscise just below the swelling, although they occasionally abscise just above it (e.g. in C. cracens and C. perangustus), leaving it as a rounded knob on the branch. This latter situation is also found in species traditionally referred to Mariscus (whether as genus or subgenus), such as C. conicus (R. Br.) Boeck., C. cyperoides (L.) Kuntze, C. aggregatus (Willd.) Endlicher and C. javanicus Houtt. Anatomical sections show an abscission layer of small thin-walled cells.

\section{Dispersal units}

At maturity, dispersal of propagules in section Pinnati takes place in one of three ways: (i) the glumes and nuts fall (together or separately), leaving the persistent rachilla; OR 
(ii) the whole spikelet falls as a unit, with or without the subtending bract and prophyll; OR

(iii) the ultimate branch falls as a unit with its terminal cluster of spikelets.

Glumes and nuts will fall together (whether in modes (i), (ii) or (iii)) if one or more of the following features is present: broad rachilla wings, broad and inrolled glume margins, viscid spikelets. Mode (i) has been considered characteristic of Cyperus sens. str., Pycreus and Anosporum, and (ii) characteristic of Mariscus, Kyllinga and Remirea. I have observed (iii) in only one other Section of the Cyperus alliance: section Decidui (with one species, C. deciduus Boeck.). [That Section was placed in subgenus Mariscus by Kükenthal but it has non-Kranz anatomy and belongs in Anosporum, whether that is treated as a genus or subgenus.]

In section Pinnati, twenty-three species exhibit more than one of these modes, the most common combination being (i) and (ii). All three modes are found in C. microcephalus, while nine species, including C. hesperius, C. sporobolus and C. fulvus, show only the first mode. This variation is rivalled in sections Laxiglumi and Glutinosi, but other exceptions to the traditional generalisations are not uncommon in subgenera Cyperus and Mariscus (sensu Kükenthal).

\section{Spikelet clusters}

In section Pinnati, spikelets are arranged in clusters at the apex of the ultimate inflorescence branches, mostly subdigitately but in some species shortly spicately. Where the arrangement is spicate (e.g. in C. cunninghamii, C. blakeanus, C. fulvus and C. perangustus), the spikelets are still relatively close-packed compared to the distantly spicate arrangement in other Sections of Cyperus (e.g. Exaltati, Rotundi, Thunbergiani).

The number of spikelets per cluster varies but species have been subjectively characterised as having 'dense' or 'loose' clusters when mature. This impression is dependent on spikelet width and maturity as well as number. The number of spikelets per cluster ranges from 1-7 in C. portae-tartari to $10->15$ in C. fulvus. When there are more than about 15 spikelets, they are clustered too densely for easy counting.

Diameter of the clusters can vary within a species, depending on growth conditions, but species generally have a characteristic combination of cluster shape and size. Shape is determined by the angle at which spikelets are held relative to the branch. Crowding can affect the angle in dense clusters but this is not the sole determinant since as few as three spikelets in a loose cluster will be spread widely. Clusters are usually hemispherical or globose in shape (rarely ovoid in C. blakeanus, C. cunninghamii, $C$. orgadophilus and C. sporobolus).

\section{Spikelets}

Spikelet shape in Cyperus is determined by the arrangement of glumes on the rachilla (which varies in the extent to which it zigzags), by the degree of lateral folding and flattening of the glumes, and by the number and crowding of glumes. Strongly laterally compressed glumes produce a compressed or flattened spikelet, rounded glumes a terete spikelet. In outline, these spikelets are respectively more or less oblong (tapering somewhat to the immature flowers at the apex) or linear. Spikelets with few glumes tend to be narrow-ovate in outline. Theoretically, the number of flowers in (and hence length of) the spikelet is unlimited, but in practice each species has a characteristic range. Unusual growth conditions may stunt or increase spikelets maturing in the following season, as discussed by Raynal (1971) for African species.

In section Pinnati, the glumes are nearly always arranged distichously on the spikelet rachilla. However, C. blakeanus occasionally exhibits spirodistichy (see, for example, Latz 3961). Spirodistichy is a twisted or distorted variant (because of crowding) of the 
distichous condition (Snow 1955), found also in Cyperus michelianus (L.) Delile and C. hamulosus M. Bieb. Rarely, spikelets are also somewhat twisted in crowded clusters in C. oxycarpus. Glumes are at least somewhat laterally compressed relative to their midrib in all species except $C$. cunninghamii, in some forms of which the glumes are rounded in cross-section, producing a terete, linear spikelet.

Spikelet size is here described in terms of the number of flowers per mature spikelet and the length and width of mature spikelets. Variation is generally not great in section Pinnati, although a few specimens (e.g. a specimen of C. fulvus, Pedersen N185 from the Burnett District of Queensland, and a specimen of $C$. alterniflorus, Milthorpe $\mathcal{E}$ Cunningham 5175 from Wanaaring, N.S.W.) have a very different facies from the usual because of long spikelets.

In section Pinnati, the rachilla is generally thin and flattened, with the flowers inserted on the two flat faces, but in a few taxa, notably C. microcephalus, C. hesperius and C. sporobolus, it becomes thickened at maturity (the lateral faces are then about 0.1$0.25 \mathrm{~mm}$ wide). The rachilla is straight or may become slightly zigzag because of pressure from the maturing nuts.

The margins of the flattened faces of the rachilla have a broad or narrow hyaline, non-vascular, discontinuous wing in most species. The base of a wing is inserted on the rachilla within the base of a glume and is not physically joined to that glume. However, the upper end (relative to the spikelet axis) of the wing joins the glume developmentally next above, i.e. on the opposite face of the rachilla. The join is NOT always with the lower margin of that upper glume as may appear at first glance and as has been stated in the past. In at least some specimens the join can be seen under the dissecting microscope to be instead along a line a fraction of a millimetre within the margin (e.g. in specimens of $C$. cracens and C. sexflorus). I have seen this also in species in other Sections, such as C. conicus (R. Br.) Boeck. and C. decompositus (R. Br.) F. Muell. in sect. Turgiduli, and C. leiocaulon Benth. (sect. Strigosi). Traditionally the wing has been explained as a basal outgrowth from the glume inserted above it on the rachilla. However, this would not seem to hold, at least for those cases in which the wing does not meet the margin of that glume. Occam's Razor suggests that it is more likely that the wing in all species is an outgrowth from the rachilla. These wings may help enclose the nut; $C$. cunninghamii is an extreme example of this. In the descriptions, the wings are classed as broad if $0.10-0.25 \mathrm{~mm}$ wide, and absent to narrow if less than $0.10 \mathrm{~mm}$ wide. Care is needed in checking for the presence of these wings because they are fragile and may be torn off when removing the glumes, especially when the spikelet is viscid as in C. ixiocarpus or C. viscidulus.

The density of glumes distichously arranged along the rachilla, coupled with the length of the glumes, is characteristic for a taxon. The point of attachment of a glume is clearly defined on the rachilla by a scar. This provides a ready means of measuring glume density: the interval between two adjacent scars on the same flattened face of the rachilla (referred to here as glume spacing). This measure has only rarely been used in the family (Denton 1978, Wilson 1981a), but is very useful diagnostically and gives a precise idea of frequency of glumes along the rachilla. It is clearly defined even on bare rachillas by the attachment scars and hence easy to measure. Glume spacing ranges from as low as $0.5 \mathrm{~mm}$ in specimens of C. holoschoenus to as high as $4.7 \mathrm{~mm}$ in C. cunninghamii. Each species has a characteristic range although there is minor intraspecific variation.

As flowers mature, glumes are generally spread farther from the rachilla. This is obviously mechanically influenced by the swelling of the ovary to form the mature nut in many cases, but in some cases the glumes remain close to the rachilla at maturity (or even enclosing the rachilla as in C. cunninghamii subsp. uniflorus). The 
degree of spreading of the glumes is generally slightly exaggerated in the drawings of spikelets in this paper, that is, the rachilla is mostly not so visible. Spikelet width is measured across the flat face of a mature spikelet between two imaginary lines drawn parallel to the rachilla through the glume apices.

\section{Glumes}

Features of the glumes important in species recognition in section Pinnati include: glume shape, size, nervation, colour, and apex and margin details, also glume spacing. As mentioned before, the glumes are at least somewhat compressed laterally producing laterally flattened spikelets, except in C. cunninghamii, in which they are often round in cross-section, enclosing the nut and forming a terete spikelet.

Since glumes are usually flattened and most readily viewed laterally, most of their features are described as seen in side view: shape, width, lateral nerve number, angle of the mucro. Thus, glume width refers to the distance from the midrib to the margin (measured at the broadest point of the glume). Lateral nerves are so generally 2-4 per side that this feature is of limited diagnostic value.

The midrib is produced in a mucro, generally short, which may continue the line of the midrib (and then termed straight) or may be excurved, or rarely incurved (in C. orgadophilus and C. sporobolus). Measurements are given both for mucro length and for glume length including mucro since many species have such a short mucro that it can be difficult to accurately measure the mucro separately. The midrib itself may be straight or curved as seen in side view. It is straight (or only slightly curved) in most taxa, but in some it is markedly curved so as to give a convex appearance to the glume mid-region, as in C. holoschoenus, C. sporobolus and C. cracens. The midrib is also markedly curved in C. cunninghamii subsp. cunninghamii and $C$. ixiocarpus but in a concave fashion.

The midrib is always at least slightly thicker in texture than the sides of the glume but it is markedly so in C. latzii and C. ixiocarpus. The midrib is smooth in all species except $C$. cracens and $C$. portae-tartari, in which it may occasionally bear prominent prickles reminiscent of those found in the American section Glutinosi and also in C. renschii Boeck. (sect. Diffusi). Occasionally, the midrib in C. holoschoenus is scabrous towards the apex.

Glume (and therefore spikelet) colour is useful diagnostically, despite the occasional exception because of abnormal growing conditions. The midrib in all species is initially green, eventually becoming dull brown with maturity. The body of the glume may be stramineous, bright yellow, golden brown or red-brown. In some species, description is complicated by the presence of yellow or red-brown blotches on a pallid background, which may alter with maturity to a more even coloration.

The actual margins of glumes usually differ in texture from the main body of the sides. Most species have hyaline or pallid, thin-membranous margins. The degree of inrolling of the margins (as well as width of rachilla wings) determines whether the nut is clasped by the subtending glume and therefore falls with it as in, for example, C. carinatus and C. cunninghamii, or whether the mature nut falls separately from the glume as in $C$. angustatus and $C$. crispulus. Nuts in species with viscid spikelets may also fall with the glume; in C. ixiocarpus, for example, the rachilla is mostly narrowly winged and the glume margins are not inrolled, but viscid secretions ensure that nut and glume fall together. 


\section{Stamens}

In section Pinnati, stamens are uniformly three in all flowers examined, although Domin (1915) reported two in C. cunninghamii (q.v.). As in the rest of the family, anthers are basifixed and introrse, opening by a longitudinal slit. They are borne on thin, strap-like, free filaments that elongate greatly at anthesis. Anther colour ranges from yellowish to reddish, varying with degree of maturity. In some species, such as C. microcephalus, the connective is produced in a fragile, reddish apical appendage. Because of the likelihood of at least portion of the appendage being broken off, separate measurements are given for mature anther and appendage length.

\section{Styles}

In section Pinnati, as in much of Cyperus sens. lat., styles are 3-fid, with the branched portion mostly as long as the unbranched portion. Differences are not diagnostically useful.

\section{Nuts}

Nut shape, size, colour, apex and surface tend to be species-specific and hence are given in detail in the descriptions. As with the glumes, the nut outline and apex are described in two-dimensional terms, qualified by trigonous or triquetrous, and with an indication of whether faces are flat, concave or convex to give a composite picture of nut shape. In most species, the nut is occasionally slightly asymmetrical because of pressure from the rachilla and/or glume during growth. This has not been mentioned in descriptions.

Nut diameter and length, in absolute terms and relative to glume length, are given in the descriptions. In most species the nut is shorter than the glume, but in some, e.g. $C$. angustatus and C. crispulus, the nut exceeds the glume and is a prominent feature of the mature spikelet. Mature nut colour ranges from pale yellowish brown to redbrown or black.

The nut surface as seen under the dissecting microscope is described in the following terms:

shining, if the surface has an even smooth gloss; glistening, if the surface reflects light so that it appears to twinkle; tuberculate, with small widely spaced elevations; colliculate, with broad rounded elevations completely covering the surface; foveate, pitted; smooth and reticulate-areolate, the surface more or less smooth or flat (at least at low magnifications), with the cell outlines obvious as a network of fine lines.

These surface conditions depend on the size of the silica body within the epidermal cells and the curvature of the outer periclinal walls of the cells (see below for details).

The last feature mentioned in descriptions is whether the nut falls as a unit with the glume or separately from it. As mentioned above, they may fall as a unit because of inrolled glume margins, broad rachilla wings, or viscidity of the spikelet.

\section{SEM study of the nut epidermis}

\section{Introduction}

The achene or nut found in most species of Cyperaceae is small and relatively uniform, offering few easily observable macro-morphological surface features. Earlier studies have concentrated on anatomical features of the pericarp visible by light microscopy, particularly the silica bodies in the epidermal cells and the mesocarp layers of sclerenchymatous fibres (Menu 1908, Marek 1958). Federowicz (1962) used plastic replicas of the surface in studying North American Cyperus species. 
The earliest SEM study of nuts in this family was of North American species of Scirpus sens. lat. and related genera by Schuyler (1971). He pointed out that more interesting features were visible if one stripped off the outer periclinal walls of the epidermal cells (in an ultrasonic cleaner or by using an acetolysis mixture) to expose the anticlinal walls and silica body (if present) on the inner periclinal wall. Studies have found little variability within a species or subspecies (e.g. Toivonen \& Timonen 1976, Piperno 1989).

The only study published on a group of Cyperus species is of the $\mathrm{C}_{3}$ section Luzulae (Denton 1983). Numerous species of Cyperus sens. lat. have been examined by Wilson and Johnson (unpubl.) as part of their study of generic limits in tribe Cypereae. As in other genera, the most significant features taxonomically have been found to be: size and shape of cells; shape and sculpturing of silica bodies; number of anticlinal walls per cell; and presence or absence of buttresses connecting the silica body to the anticlinal cell walls.

Silica is commonly deposited in cells of grasses and sedges, in a hydrated amorphous form polymerised from monosilicic acid, which is absorbed by the roots from soil solution (Raven 1983). The deposits may form either discrete bodies or thin layers conforming to the shape of the cell-walls. The bodies are usually called silica bodies or aggregates (Sangster \& Parry 1981) or phytoliths (Piperno 1989). Their surface detail can be seen with the SEM after treatment to remove the outer periclinal cellwalls (e.g. Le Cohu 1973, Gordon-Gray et al. 1978).

In the Cyperaceae, the discrete bodies have a flattish base of an area corresponding to that of the inner periclinal cell-wall, with one or more relatively large, more or less conical bodies seated on that base and projecting into the lumen of the cell. The bodies may show various secondary sculpturing. Development of the bodies in Cyperus has not yet been investigated but Ragonese et al. (1984) describe similar silica bodies in Rhynchospora as beginning as a basal pad on the inner periclinal wall and 'growing' in a more or less conical shape into the lumen as more silica is deposited. There is greater interspecific variation in form in fruits than is found in vegetative parts (see below).

\section{Methods}

\section{Survey of section Pinnati}

Mature nuts were examined intact, or were soaked in an acetolysis mixture (9:2 acetic anhydride : sulphuric acid) for 1-6 hours, after which the outer periclinal walls either floated off as a complete layer or could be gently removed with forceps. The nuts were then stored in absolute alcohol until wanted for examination with the light or scanning electron microscopes. For SEM examination, they were air-dried for a few minutes before mounting on stubs. Most samples were gold-coated before being observed and photographed in the SEM. Two machines were used: a Cambridge Stereoscan S4-10 at the University of New South Wales and an ISI-40 at the Royal Botanic Gardens (the latter had lower resolution than the former).

The standard observation point was about midway along the length of the nut.

\section{Features of epidermal layer}

Features that were observed in the species of this Section include: nut surface; cell shape and size as seen in surface view; sinuosity and thickness of anticlinal walls; and silica body shape, including apex shape, and secondary ornamentation of the body and base.

Nut surface. Four patterns were found: (i) outer periclinal wall convex or inflated, and silica bodies not as tall as the anticlinal walls, (ii) periclinal wall flat and the surface 

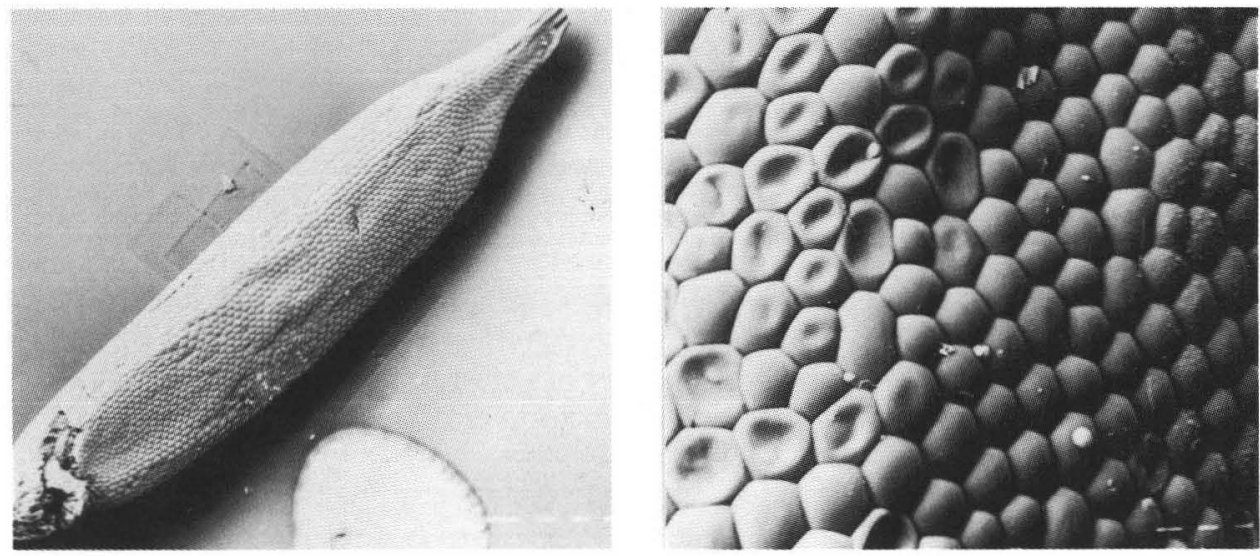

a

b

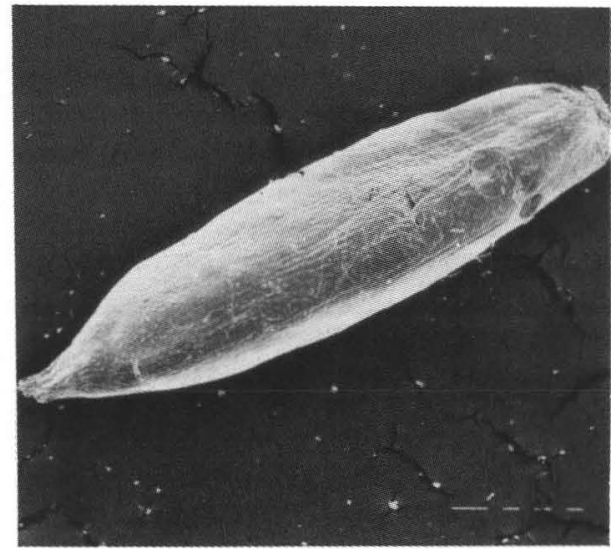

C

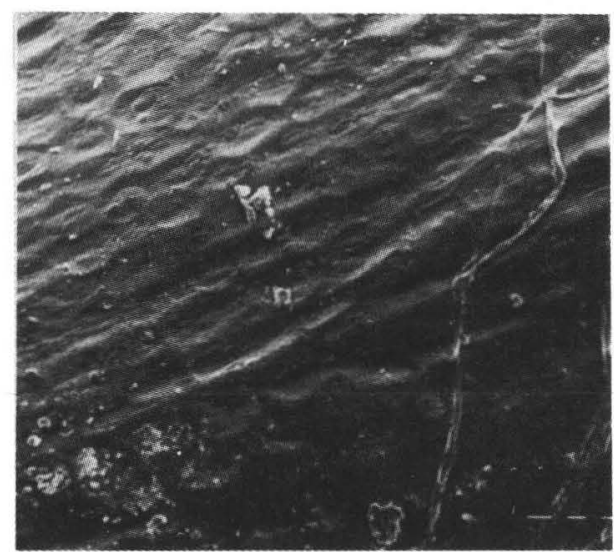

d
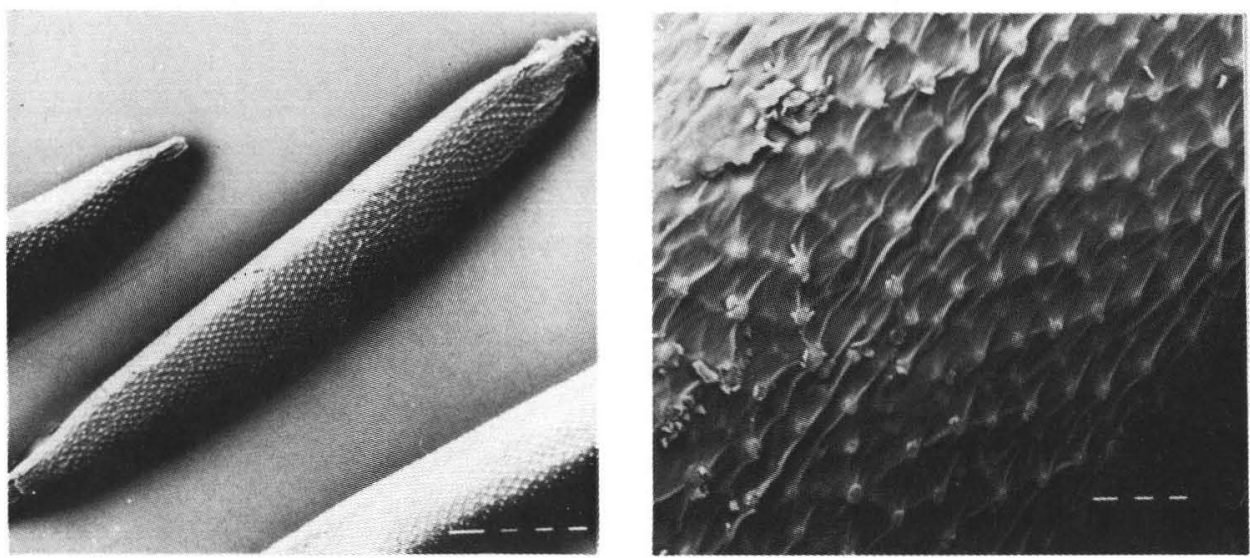

f

Figure 2. Nut surface types in species of section Pinnati. a, b, Colliculate surface of $C$. betchei subsp. commiscens (note some cells with concave outer periclinal walls: a presumed artifact); c, d, more or less smooth, reticulate-areolate surface of $C$. holoschoenus (smooth as seen under dissecting microscope); $\mathbf{e}, \mathbf{f}$, tuberculate surface of $C$. cunninghamii subsp. uniflorus. Scale: a, $\mathrm{X}$ 35, b, X 270 (from Latz 7090); c, X 37, d, X 250 (Wilson 5331); e, X 37, f, X 260 (Dunlop 5842). [Scale bar (left-most bar on micrographs from the ISI-40 SEM) $=100 \mu \mathrm{m}$ when followed by three dashes; $=10 \mu \mathrm{m}$ when followed by two dashes.] 
nearly smooth (mostly with slightly uneven surface), silica bodies not as tall as the anticlinal walls, (iii) periclinal wall collapsed but draped over a silica body that is taller than the anticlinal walls, and (iv) periclinal wall sunken within the anticlinal walls of each cell without a tall silica body to support them.

These four patterns correlate with the surface morphology as seen with the dissecting microscope. Pattern (i) corresponds to the surface description colliculate (Figure 2a, b), pattern (ii) to smooth and areolate-reticulate (Figure $2 \mathrm{c}, \mathrm{d}$ ), pattern (iii) to tuberculate (Figure $2 \mathrm{e}, \mathrm{f}$ ), and (iv) to foveate (Figure $3 \mathrm{a}, \mathrm{b}$ ). Nuts with convex outer periclinal walls (that is, a colliculate surface) sometimes had a few walls collapsed but this appeared to be an artifact of observation in a vacuum; it did not correspond to the foveate or tuberculate surfaces found in other species.

The full extent of variation within species is not known since no more than four samples per species were examined. There was some intraspecific variation, particularly between having convex or more or less flat outer periclinal walls, so that these cannot be regarded as fully resolved characters yet. Some of the variation seen may be due to the different resolutions of the SEMs used; this was not investigated.

Cell shape. Most species have isodiametric epidermal cells (Figure 3c) as seen in surface view. Although predominantly 6 -sided, the cells on any nut can vary from 4- to 7 -sided, with a tendency to more elongated cells at the extremities of the nut. In a few species, e.g. C. crispulus and C. cunninghamii, the cells are usually elongated along the longitudinal axis of the nut (Figure 3d). Most taxa were uniform in their cell shape. However, there was some variation between samples of $C$. rigidellus, a species that is morphologically variable.

Cell size. Cell size (as seen in surface view) is rarely uniform on any one nut: generally a range of sizes is present. Largest are the elongate cells of $C$. cunninghamii and C. dactylotes, which range from $25 \mu \mathrm{m}$ to $50 \mu \mathrm{m}$ along their long axis (c. $10-15 \mu \mathrm{m}$ across the short axis). The largest isodiametric cells are found in C. isabellinus (30-50 $\mu \mathrm{m})$. The smallest cells are found in C. oxycarpus $(12-20 \mu \mathrm{m})$.

Sinuosity and thickness of anticlinal walls. A few taxa have markedly sinuate anticlinal walls, e.g. C. oxycarpus and C. holoschoenus (Figure 3c). Some, such as C. perangustus, have slightly sinuate walls (as seen at about 300X), but more than half the taxa have straight anticlinal walls. A few species show variation in this character (e.g. C. portaetartari, C. holoschoenus and C. lhotskyanus). These walls are generally thin, but are somewhat thickened in C. latzii, C. viscidulus and C. clarus (Figure 3e).

Silica bodies. All taxa have silica bodies in the epidermal cells, as in the vegetative parts. Each cell has one main central body per cell, more or less conical and with its base covering the inner periclinal wall. The lateral faces of the central body range from concave to plane. This, allied with the truncate, broadly acute or concave apex, produces bodies that can be likened to mesas (Figure 3f), cones (Figure 4a) and volcanoes (Figure $4 \mathrm{~b}$ ). In the mesa-like bodies, the lateral faces tend to narrow towards the middle and then spread near the apex (i.e. the body often has a 'waist').

Most taxa have a central body that is small in basal area relative to the cell lumen, with concave or plane faces sloping down to the more or less flat base, so that the erect body is obviously isolated on the cell's inner periclinal wall (Figure 3d). However, in a few taxa, e.g. C. perangustus (Figure 4c, d), the central body is large and covers the entire periclinal wall.

The apex of the body ranges from broadly acute (Figure $4 \mathrm{a}$ ) to truncate (Figure $3 \mathrm{f}$ ), concave (Figure $4 \mathrm{~b}$ ) or even coronate with several to numerous linear processes diverging from the small-circular apex (Figure 4c, d). In most taxa the apex is truncate, often with a 


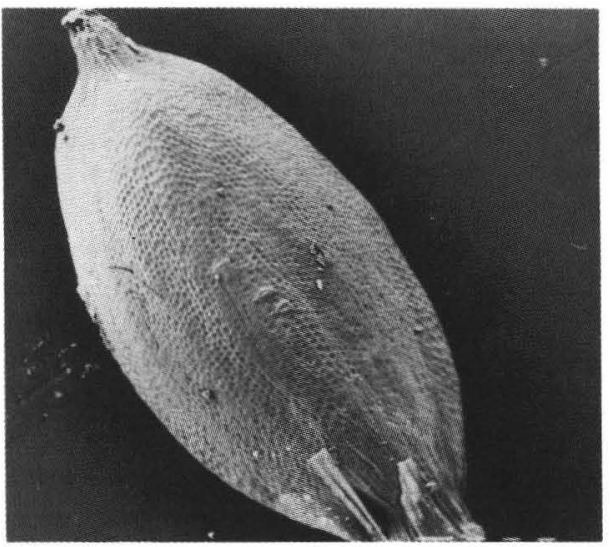

a

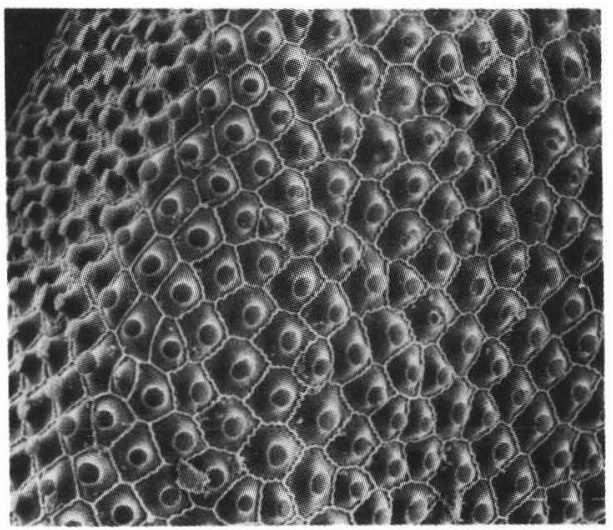

C

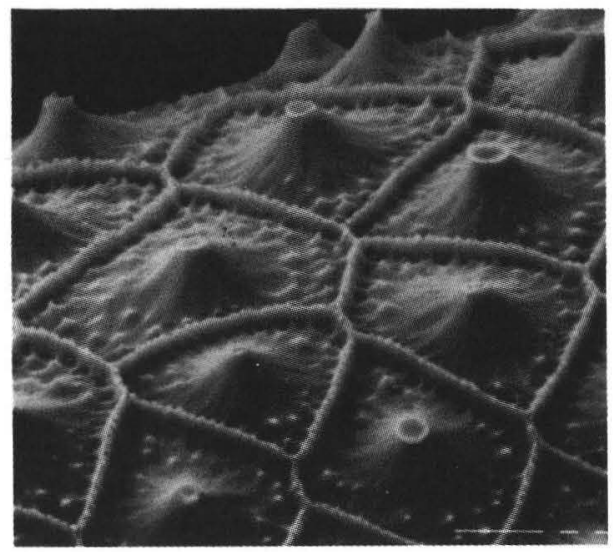

e

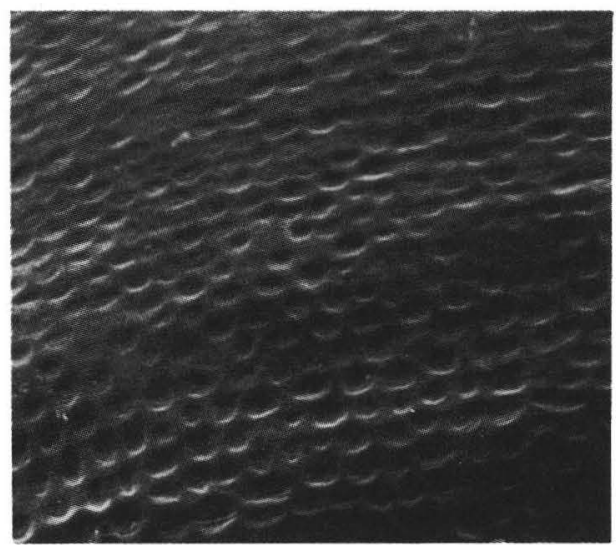

b

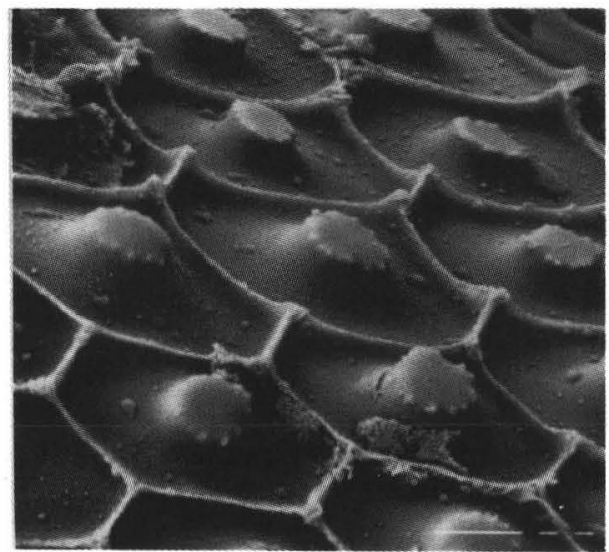

d

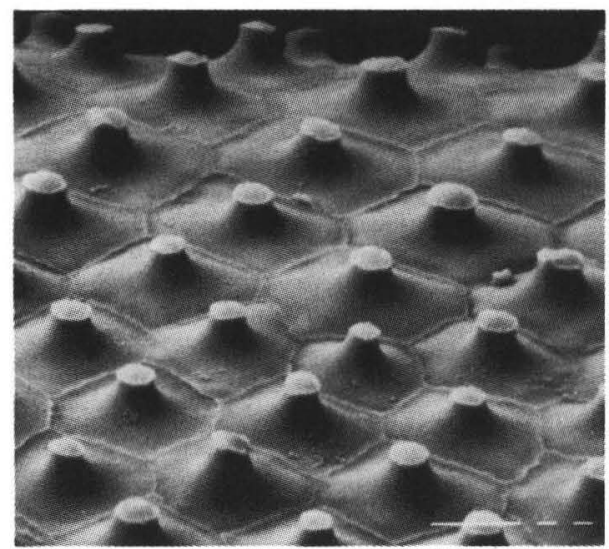

f

Figure 3. Nut surface types (cont.). $\mathbf{a}, \mathbf{b}$, Foveate surface of $C$. viscidulus.

Features of nut epidermal cells, as seen with outer periclinal cell-wall removed. c, Isodiametric cells with sinuate anticlinal walls, C. holoschoenus; d, elongated cells with straight anticlinal walls and central silica body that is small in area compared to the cell lumen and has a fringed apex, C. cunninghamii subsp. cheradicus; e, cells with thickened walls and buttresses, C. clarus; $\mathbf{f}$, mesalike silica body with broad flattened apex, C. dactylotes. Scale: a, X 35, b, X 180 (Beauglehole 47687); c, X 200 (Wilson 5331); d, X 920 (Wilson 5495); e, X 1750 (Wilson 4326); f, X 920 (Latz 5126). [Scale bar (left-most bar on micrographs from the ISI-40 SEM) $=10 \mu \mathrm{m}$ when followed by two dashes.] 


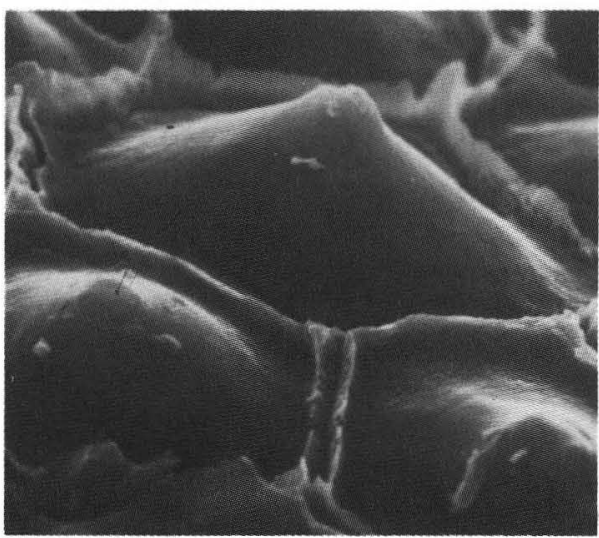

a

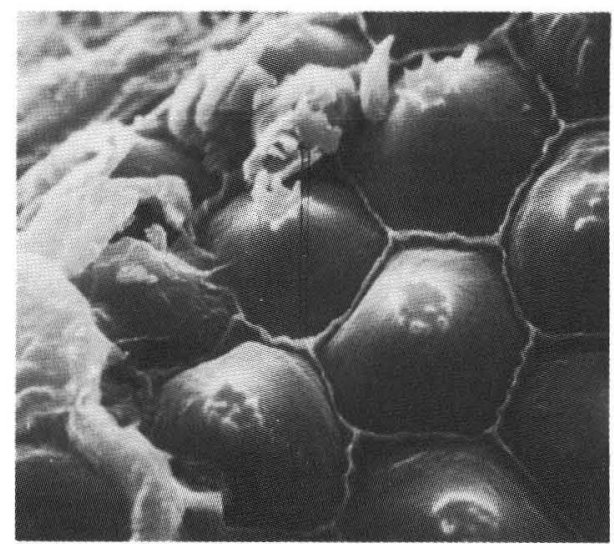

C

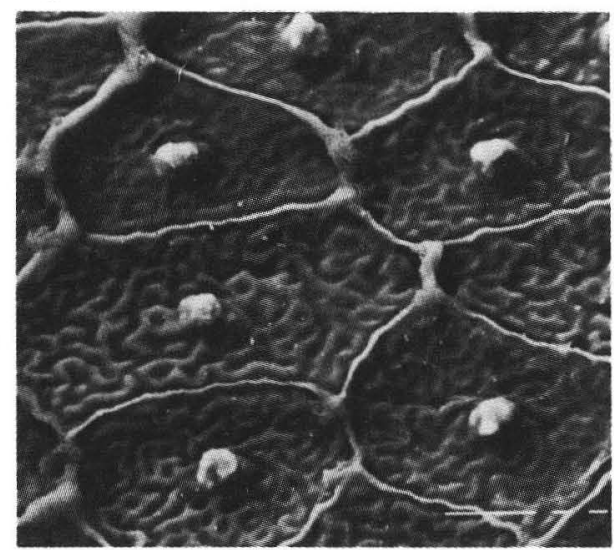

e

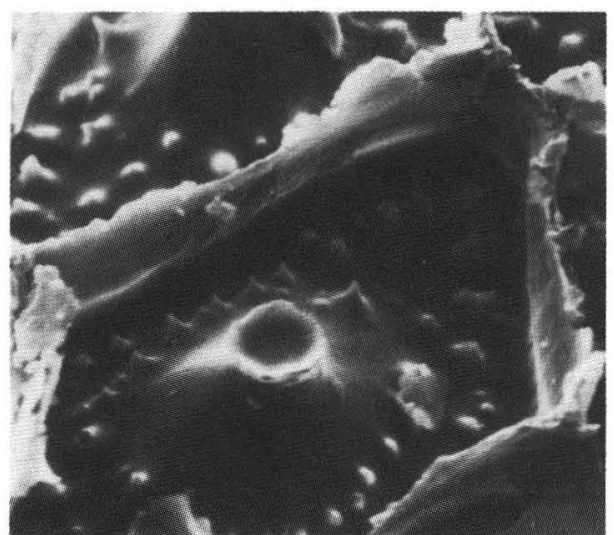

b

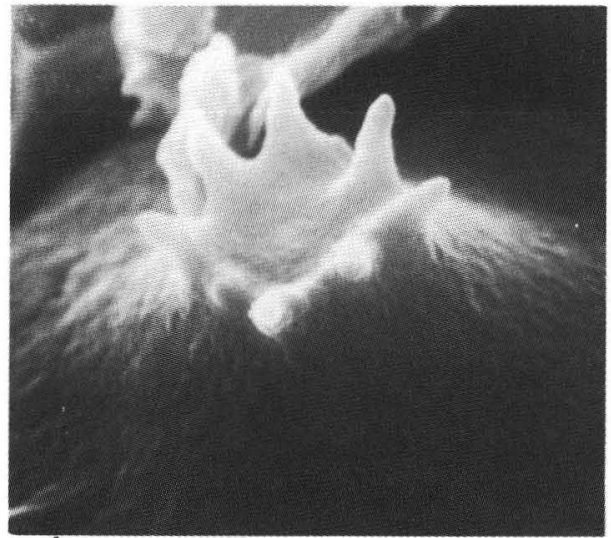

d

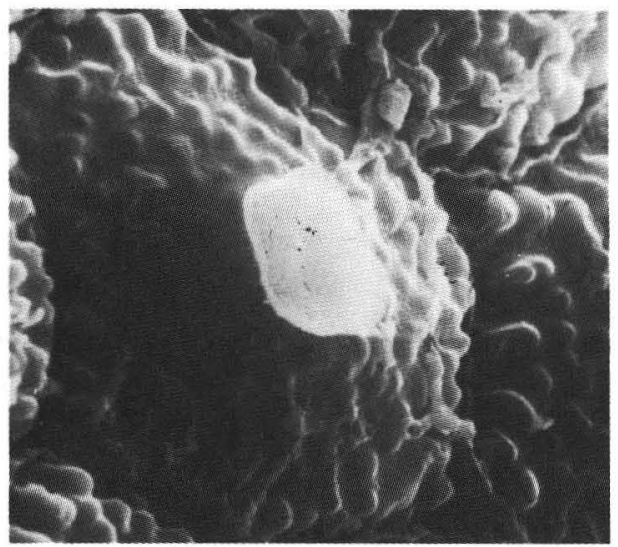

f

Figure 4. Features of nut epidermal cells, as seen with outer periclinal cell-wall removed. a, Conical silica body with broadly acute apex and smooth surface, C. lhotskyanus; b, volcano-shaped silica body with concave apex and with tuberculate secondary ornamentation, $C$. fulvus; $\mathbf{c}, \mathbf{d}$, large silica body filling cell lumen, with coronate apex, C. perangustus; e, small central silica body with rugose secondary ornamentation on base, $C$. centralis; $\mathbf{f}$, large body with flat apex (obscured by charging) and papillate secondary and tertiary ornamentation, C. ixiocarpus. Scale: a, X 4000 (Beauglehole 49697); b, X 3900 (Coveny 3916); c, X 1900, d, X 9000 (Blake 11304); e, X 940 (Latz 2134); $\mathrm{f}, \mathrm{X} 3900$ (Latz 6698). [Scale bar (left-most bar on micrographs from the ISI-40 SEM) $=10 \mu \mathrm{m}$ when followed by two dashes; $=1 \mu \mathrm{m}$ when followed by one dash.] 
fringe of minute processes spreading laterally (e.g. in C. cunninghamii subsp. cheradicus (Figure 3d)).

Secondary ornamentation was mostly observed at about 200-600X magnification. There was some evidence of further ornamentation being visible at even higher magnifications, such as the 'papillae on papillae' in C. ixiocarpus (Figure 4f). The surface of the silica body and its base varies from smooth (Figure 4a) to rugose (Figure 4e), papillate (Figure $4 \mathrm{f}$ ) or tuberculate (Figure $4 \mathrm{~b}$ ). Smooth surfaces are most common but secondary sculpturing is found in some taxa, often only on the base. Smooth central bodies with a rugose base are found in a few species, such as C. crispulus and C. microcephalus, and with a tuberculate base in C. fulvus (Figure $4 \mathrm{~b}$ ). Only C. viscidulus and C. clarus (Figure 3e) show what Denton (1983) terms buttresses: strong ridges connecting the anticlinal walls and the basal part of the silica body.

\section{Discussion}

The nut characters discussed above show promise of being useful taxonomically at the species level, as Denton (1983) found with Cyperus section Luzulae, or in delimiting subgroups of related species, e.g. C. fulvus, C. gilesii and C. clarus. However, the full extent of intraspecific and developmental variation needs to be determined before these characters can be used with confidence in this group. Coronate apices, for example, may be an elaboration of the fringed flattish type; both can certainly be found in the same taxon (e.g. C. carinatus) although not on the same nut. Similarly, conical bodies are only found in species of which other specimens have mesa-type bodies and hence may only represent an early stage of development of the body.

\section{Vegetative anatomy}

\section{Materials and methods}

Fresh leaf and culm material was used for sectioning whenever available, but mostly samples from dried herbarium specimens were used, after boiling up in water with a few drops of detergent. Most sections were cut by hand with a razor blade, a few were done on rotary or sledge microtomes. Some sections were stained with toluidine blue, but most were not stained as the main interest lay in the tissue patterns and these were readily visible without staining. As part of the general survey of Cyperus sens. lat., sections (mainly of leaves) had been cut previously for many species and these were useful for comparative purposes. Metcalfe's (1971) anatomical survey of the family Cyperaceae provided a good basis for terminology and comparison. Druyts-Voets' survey (1970) of Cyperus species (mainly those in subgenus Cyperus sensu Kükenthal) was also useful.

Culm sections were cut about halfway along the length of the culm. Leaf sections were cut about halfway between the lamina base and the apex. Multiple sectioning of a few species established that species are generally consistent in their anatomical patterns as long as comparably mature samples are chosen. If, however, one compares an immature with a more mature leaf, there may be differences. For example, a senescent and an immature leaf from the same tuft of a specimen of $C$. orgadophilus were sectioned and showed differences in outline and in development of bulliform cells and adaxial subepidermal sclerenchyma strands. For most species, only one or two sections (from mature leaves and culms) were cut. Features were tabulated for all taxa, as well as for a few other species of Cyperus for comparison (Tables 1, 2). Representative sections were drawn using Metcalfe's (1971) conventions for shading of tissues. 


\section{Features common to culms and leaves}

Epidermal cells are smaller over sclerenchyma strands in both leaves and culms, and mostly contain silica bodies, which are conical as seen in cross-section, with the base resting on the inner periclinal wall. This is in contrast to the variety of shapes seen in silica bodies in nut epidermal cells (page 373). The number of silica bodies per cell varies from one to four, all in a single row so far as seen.

Stomates are found only on the abaxial surface of the leaf. Mature stomates are paracytic in Metcalfe's terminology (brachyparacytic, Dilcher 1974), i.e. with the guard cells each laterally in contact with one subsidiary cell but the polar regions of the stomates in contact with the ordinary epidermal cells. The cuticle varies little and hence is not described.

Vascular bundles are collateral, and chlorenchyma is radiate around the bundles. This is characteristic of the anatomy termed Kranz (see, e.g. Brown 1975), which is correlated with the $\mathrm{C}_{4}$ type of photosynthesis (see page 391 for further discussion).

The distinctive arrangement of vascular bundles and associated bundle sheaths and radiate chlorenchyma around large air-cavities in both leaves and culms is of Metcalfe's Mariscus A-anatomy type or modifications thereof (Figures 5-7). This arrangement is also found in species of sections Glutinosi, Thunbergiani and Turgiduli. There are small commissural (cross-connecting) vascular strands in the air-cavities in some crosssections, apparently linking up to six of the vascular strands around an air-cavity.

\section{Leaf T.S.}

The leaves are dorsiventral, that is, all vascular bundles have the same orientation, and the adaxial epidermis is distinguishable from the abaxial epidermis. The leaves of all species are triangular if sectioned near the apex, and broadly U-shaped or crescentiform towards the sheath region (Figure 5).

Outline of leaf cross-sections. The outline at the halfway point ranges from broadly $V$ shaped (Figure 5c) to thickly crescentiform (Figure 6a), which correlates with the prominence of the midrib. It is often slightly asymmetrical, especially in the species with more crescentiform cross-sections (e.g. C. blakeanus and C. secubans).

The outline is generally smooth, but is somewhat uneven in various species, which correlates variously with raised or sunken stomates (e.g. C. astartodes, C. secubans) or position of sclerenchyma strands (e.g. C. carinatus, C. cunninghamii, C. holoschoenus) or unevenly thickened cuticle (C. crispulus). All species have marginal prickle hairs, which may or may not be seen in a T.S.; these have not been tabulated but are included in each species' description. Some species (especially C. microcephalus and C. portaetartari) may occasionally be scabrous on the abaxial surface as well.

Epidermis. The cells of the adaxial epidermal layer range from only slightly larger than to twice as large as those of the abaxial layer (which accords with Metcalfe's definition of A-anatomy). In most of the species, the adaxial cells are about twice as large but they are nearly the same size in some specimens of $C$. gunnii and C. alterniflorus. In all taxa the epidermal cells are smaller over sclerenchyma strands.

Bulliform cells. These are present in the midrib region of the adaxial epidermis in about two-thirds of the cross-sections. In general, species characteristically either possess or lack bulliform cells, but in some species (e.g. C. betchei and C. fulvus) both conditions occur, as suggested by Metcalfe (1971). In at least some species there is variation with stage of growth: they were absent from a young leaf of $C$. orgadophilus (Wilson 5373) but present in a fully elongated leaf from the same plant. In a specimen 
Table 1. Anatomical features of leaves, as seen in cross-section, of species in Cyperus sect. Pinnati. Examples from various other Sections are included for comparison.

Species

1

45

6

7

8

10

Sect. Pinnati

cunninghamii

$\begin{array}{lllllllllll}\text { ssp. cunninghamii } & \mathrm{C} & + & -/+ & -/ 1 & \mathrm{na} /+ & 1-6 & 2 & \mathrm{~cd} & 2 & - \\ \text { ssp. cheradicus } & \mathrm{dV} & + & - & - & \mathrm{na} & 3 & 2 & \mathrm{c} & - & -\end{array}$

ssp. cheradicus

(young leaf)

ssp. cheradicus

(old leaf)

ssp. uniflorus

astartodes

hesperius

microcephalus

ssp. chersophilus

ssp. saxicola

crispulus

sexflorus

portae-tartari

cracens

sporobolus

orgadophilus

(young leaf)

orgadophilus

(old leaf)

blakeanus

angustatus

ixiocarpus

viscidulus

carinatus

holoschoenus

oxycarpus

betchei

ssp. betchei

ssp. commiscens

dactylotes

fucosus

gunnii

ssp. gunnii

ssp. novae-

hollandiae

alterniflorus

Ihotskyanus

centralis

secubans

isabellinus

rigidellus

clarus

fulvus

perangustus

gilesii

latzii

$\begin{array}{llllllllll}v & + & + & 1 & + & 1 & 2 & \mathrm{c} & 2 & + \\ v & + & + & 2 & - & 1-2 & 2-3 & \mathrm{~cd} & 2 & + \\ v & + & +/- & 1-2 /- & -/ n a & 2 & 1-2 & \mathrm{c} & 2 & + \\ \mathrm{c} v & + & - & 1 & + & 1 & 2 & \mathrm{c} & 2 & - \\ \mathrm{c} v & + & - & - & \text { na } & 2-8 & 1-2 & \mathrm{cb} & 2 & +\end{array}$

$\begin{array}{llllllllll}\mathrm{v} & + & +/- & 1-3 & - & 1-3 & 1 & \mathrm{cb} & 2 & ++ \\ \mathrm{ac} & + & +/- & -11-2 & \mathrm{na} /+ & 1-2 & 1-2 & \mathrm{cb} & 1 & -/+ \\ \mathrm{ac} & + & -/+ & -/ 1 & \mathrm{a} /+ & 1-5 & 1 & \mathrm{cb} & -11-2 & - \\ \mathrm{ac} & + & -/+ & - & \mathrm{na} & 1-9 & 2-3 & \mathrm{~cd} & 1-2 & - \\ \mathrm{v} & + & - & 1 & + & 1 & 1-2 & \mathrm{bc} & 2-3 & + \\ \mathrm{v} & + & - & 1-2 & +/- & 1-2 & 2 & \mathrm{cb} & 2-3 & +/++ \\ \mathrm{ac} & + & +/- & - & \mathrm{na} & 1-4 & 2-3 & \mathrm{c} & 2 & -/+ \\ \mathrm{ac} & + & - & - & \mathrm{na} & 2-4 & 2 & \mathrm{c} & 2 & +/\end{array}$

ac

$$
\mathrm{v}
$$

ac

ac

ac +

c

v

$v$

c

$+$

- na $1-3 \quad 3 \quad$ cd $2+$

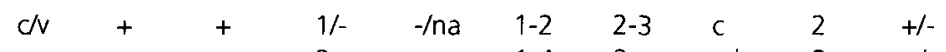

$v+\quad+\quad 2-\begin{array}{lllllll}1-4 & 2 & \mathrm{~cd} & 3 & +\end{array}$

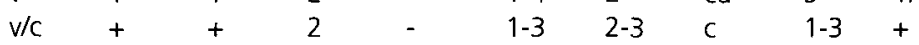

c + - $\quad-$ na $1-4 \quad 2-3$ d $2 \begin{array}{lllll} & \end{array}$

$v+\quad+\quad-/ 2 \quad n a /+\quad 1-3 \quad 3-4$ cd $1-3 \quad+/-$

$\begin{array}{llllllllll}v & + & + & 2 & -/+ & 2-3 & 3 & \mathrm{c} & 4 & ++ \\ v & + & + & 1-2 & - & 2-3 & 3-4 & \mathrm{c} & 2-4 & ++ \\ \mathrm{c} v & + & + & 1 & +/ & 1-4 & 3-4 & \mathrm{~cd} & 2-3 & - \\ \mathrm{v} / \mathrm{c} & + & + & 1 & - & 1-2 & 2 & \mathrm{~cd} & 2 & +- \\ \mathrm{ac} & + & - & - & \text { na } & 3-11 & 2-3 & \mathrm{c} & (2) & - \\ \mathrm{v} & + & + & 1 & - & 1 & 2 & \mathrm{cb} & 2 & + \\ \mathrm{c} & + & - & 1-2 & - & 1-2 & 2 & \mathrm{cbd} & 1-2 & -/+ \\ v & + & - & 1-2 & - & 1 & 1-2 & \mathrm{cb} & 1-2 & + \\ v & + & +/- & 1 /- & -/ n a & 1-2 & 2-3 & \mathrm{cbd} & 1-2 & + \\ v & + & + & 1 & -- & 1 & 2 & \mathrm{~b} & 2 & ++ \\ v & + & - & 1-2 & - & 1 & 1 & \mathrm{bd} & 2 & +- \\ v & + & - & 1 /- & + \text { /na } & 1 & 2 & \mathrm{c} & 2 & +\end{array}$ 


$\begin{array}{lllllllllll}\text { Species } & 1 & 2 & 3 & 4 & 5 & 6 & 7 & 8 & 9 & 10\end{array}$

\section{Sect. Glutinosi}

elegans

oxylepis

rubiginosus

trachysanthos

$\begin{array}{llllllllll}v ? c & + & -/+ & - & \text { na } & 4-7 & 2-4 & d & -/ 2 & - \\ c & + & + & - & \text { na } & 4-6 & 2-3 & d & -12 & - \\ v & + & +/- & -/ 1 & \text { na/ }+ & 1-2 & 1-2 & \text { bd } & 2 & + \\ c & + & - & - & \text { na } & 3-7 & 2-3 & d & 3 & -\end{array}$

\section{Sect. Subquadrangulares}

tenuiculmis

Sect. Thunbergiani

lucidus

\section{v}

$$
+
$$

$+1-$

$S$

$3++$

Sect. Turgiduli

conicus

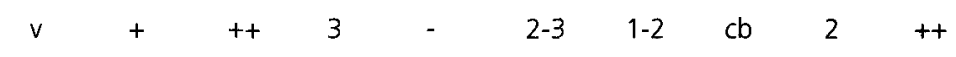

Column 1. Shape in outline: a, asymmetrical; c, crescentiform; $v, v$-shaped.

Column 2. Epidermal cells over sclerenchyma strands: + , smaller; - , same size as other epidermal cells.

Column 3. Sclerenchyma strands: +, present immediately beneath adaxial epidermis; -, absent from that position.

Column 4. Number of layers of bulliform cells.

Column 5. Bulliform cells: +, raised relative to adjoining epidermal cells; -, level; - -, depressed.

Column 6. Number of layers of hypodermal cells.

Column 7. Number of vascular bundles per girder.

Column 8. Arrangement of vascular bundles (i) around air-cavities: $c$, completely encircling cavities; $b$, abaxial layer incomplete; $d$, adaxial layer incomplete; (ii) in single row: $s$.

Column 9. Number of sclerenchyma strands associated with midrib.

Column 10. Midrib: +, obvious anatomically; -, not obvious. 
Table 2. Anatomical features of culms, as seen in cross-section, in species of Cyperus sect. Pinnati. Examples from various other Sections are included for comparison.

\begin{tabular}{lllllllll} 
Species & 1 & 2 & 3 & 4 & 5 & 6 & 7 \\
\hline
\end{tabular}

Sect. Pinnati

cunninghamii

\begin{tabular}{|c|c|c|c|c|c|c|}
\hline ssp. cunninghamii & $\operatorname{tg}$ & $f / r$ & + & $\mathrm{t}, \mathrm{bt}$ & - & + \\
\hline ssp. cheradicus & $\operatorname{tg}$ & $f$ & + & $t, 0$ & - & + \\
\hline ssp. uniflorus & $\operatorname{tg}$ & $f / r$ & + & $50, b t$ & - & + \\
\hline astartodes & $\operatorname{tg}$ & $f$ & + & $\mathrm{tt}$ & - & + \\
\hline $\begin{array}{l}\text { hesperius } \\
\text { microcephalus }\end{array}$ & $\operatorname{tg}$ & $f$ & + & $\mathrm{t}$ & $-/+$ & - \\
\hline ssp. microcephalus & $\operatorname{tg}$ & $\mathrm{f} / \mathrm{s}$ & + & tt & $+1-$ & + \\
\hline ssp. chersophilus & $\operatorname{tg}$ & $f$ & + & $t$ & - & + \\
\hline ssp. saxicola & $t$ & $f$ & + & $t, b t$ & - & - \\
\hline crispulus & $\operatorname{tg}$ & $f$ & + & $\mathrm{tt}$ & - & - \\
\hline sexflorus & $\operatorname{tg}$ & $f$ & + & $\mathrm{tt}, \mathrm{t}$ & - & + \\
\hline portae-tartari & g & $f / r$ & + & t, so & $+/-$ & + \\
\hline cracens & gt & $f$ & + & $\mathrm{t}, \mathrm{bt}$ & - & + \\
\hline sporobolus & $\operatorname{tg}$ & $f$ & + & $t, b t$ & - & + \\
\hline orgadophilus & $\operatorname{tg}$ & $f$ & + & $\mathrm{t}$ & - & + \\
\hline blakeanus & gt & $f$ & + & bt & - & + \\
\hline angustatus & $\operatorname{tg}$ & $f$ & + & 0 & - & + \\
\hline ixiocarpus & $\mathrm{t}$ & $f$ & + & $\mathrm{tt}, \mathrm{t}$ & - & + \\
\hline viscidulus & gt & $f$ & + & $t$ & - & + \\
\hline carinatus & gt & $f$ & + & bt & - & + \\
\hline holoschoenus & gt & $f$ & $+/-$ & 0 & - & + \\
\hline $\begin{array}{l}\text { oxycarpus } \\
\text { betchei }\end{array}$ & g & $f$ & + & $\mathrm{tt}$ & $+1-$ & + \\
\hline ssp. betchei & gt & $f$ & + & $\mathrm{tt}$ & - & + \\
\hline ssp. commiscens & gt & $f / s$ & + & 0 & - & + \\
\hline dactylotes & $\operatorname{tg}$ & $\mathrm{f} / \mathrm{s}$ & + & 0 & - & + \\
\hline $\begin{array}{l}\text { fucosus } \\
\text { gunnii }\end{array}$ & $\mathrm{t}$ & $f$ & + & 0 & - & + \\
\hline ssp. gunnii & gt & $f$ & + & $t$ & - & + \\
\hline $\begin{array}{l}\text { 5sp. novae- } \\
\text { hollandiae }\end{array}$ & qg & $f$ & + & $b t, t$ & - & + \\
\hline alterniflorus & qg & $f$ & $+1-$ & $0, \mathrm{tt}$ & - & + \\
\hline Ihotskyanus & gt & $f$ & + & $\mathrm{tt}, \mathrm{t}, \mathrm{o}$ & $+1-$ & + \\
\hline centralis & $\mathrm{gq}$ & $f$ & + & $\mathrm{t}$ & - & + \\
\hline secubans & $\mathrm{t}$ & $f / r$ & + & $b t, t$ & - & + \\
\hline isabellinus & gt & $f$ & + & $t$ & - & + \\
\hline rigidellus & qgt & $f$ & + & $b t, t$ & - & + \\
\hline clarus & qg & f & + & $b t, t$ & $+1-$ & + \\
\hline fulvus & gqt & $f / r$ & $+/-$ & $\mathrm{t}, \mathrm{bt}$ & $-1+$ & + \\
\hline perangustus & qg & $f$ & + & $\mathrm{t}, \mathrm{tt}$ & $+1-$ & + \\
\hline gilesii & $\mathrm{gq}$ & $f$ & + & $b t, t$ & - & $-/+$ \\
\hline latzii & gt & $f$ & + & t & - & + \\
\hline
\end{tabular}

Sect. Glutinosi

elegans

oxylepis

tg $f+t, t+\frac{t}{f}+\frac{t}{c}$

Sect. Subquadrangulares

tenuiculmis

g

f t- to 


$\begin{array}{llllllll}\text { Species } & 1 & 2 & 3 & 4 & 5 & 6 & 7\end{array}$

\section{Sect. Thunbergiani}

lucidus

q f $\quad+$ so,t $-\quad+\quad$ c

Sect. Turgiduli

conicus

$\mathrm{t} f / \mathrm{s}+\mathrm{o}, \mathrm{tt}+\mathrm{t}+\mathrm{c}$

Column 1. Shape in outline: $g$, trigonous; $q$, triquetrous; $t$, terete.

Column 2. Stomates relative to adjacent epidermal cells: $f$, flush; $r$, raised; s, sunken.

Column 3. Epidermal cells over sclerenchyma strands: +, smaller; - , same size as other epidermal cells.

Column 4. Shape of sclerenchyma strands: o, oblong I: to, transversely oblong =; so, short-oblong ,; $\mathrm{t}$, triangular $\mathbf{\Lambda}$ : tt, tall-triangular $\mathbf{\Lambda}$; bt, broad-triangular

Column 5. Sclerenchyma strands: +, all about the same size; -, various sizes in the one section.

Column 6. Large peripheral air-cavities: + , present; -, absent.

Column 7. Vascular bundles in central ground tissue: 0 , only in outer $1 / 2-2 / 3 ; C$, throughout central ground tissue. 
of C. cunninghamii subsp. cheradicus (Wilson 4894) they were raised above the surface in a young leaf but flush with the surface in a senescent leaf from the same plant. A second layer of bulliform cells was found in about one-third of the samples (e.g. in C. alterniflorus, C. carinatus and C. portae-tartari); a third layer was found in one section of C. microcephalus ssp. microcephalus. The bulliform cells are generally level with the rest of the adaxial epidermis (Figure $6 \mathrm{~h}-\mathrm{j}$ ) but they are raised in a few species (C. astartodes, C. microcephalus subsp. chersophilus (Figure 6e, g) and C. sexflorus) and, as mentioned above, their level differed in young and mature leaves of a plant of C. cunninghamii subsp. cheradicus. In C. perangustus, the bulliform cells are unusual in being sunken relative to the surrounding epidermal cells.

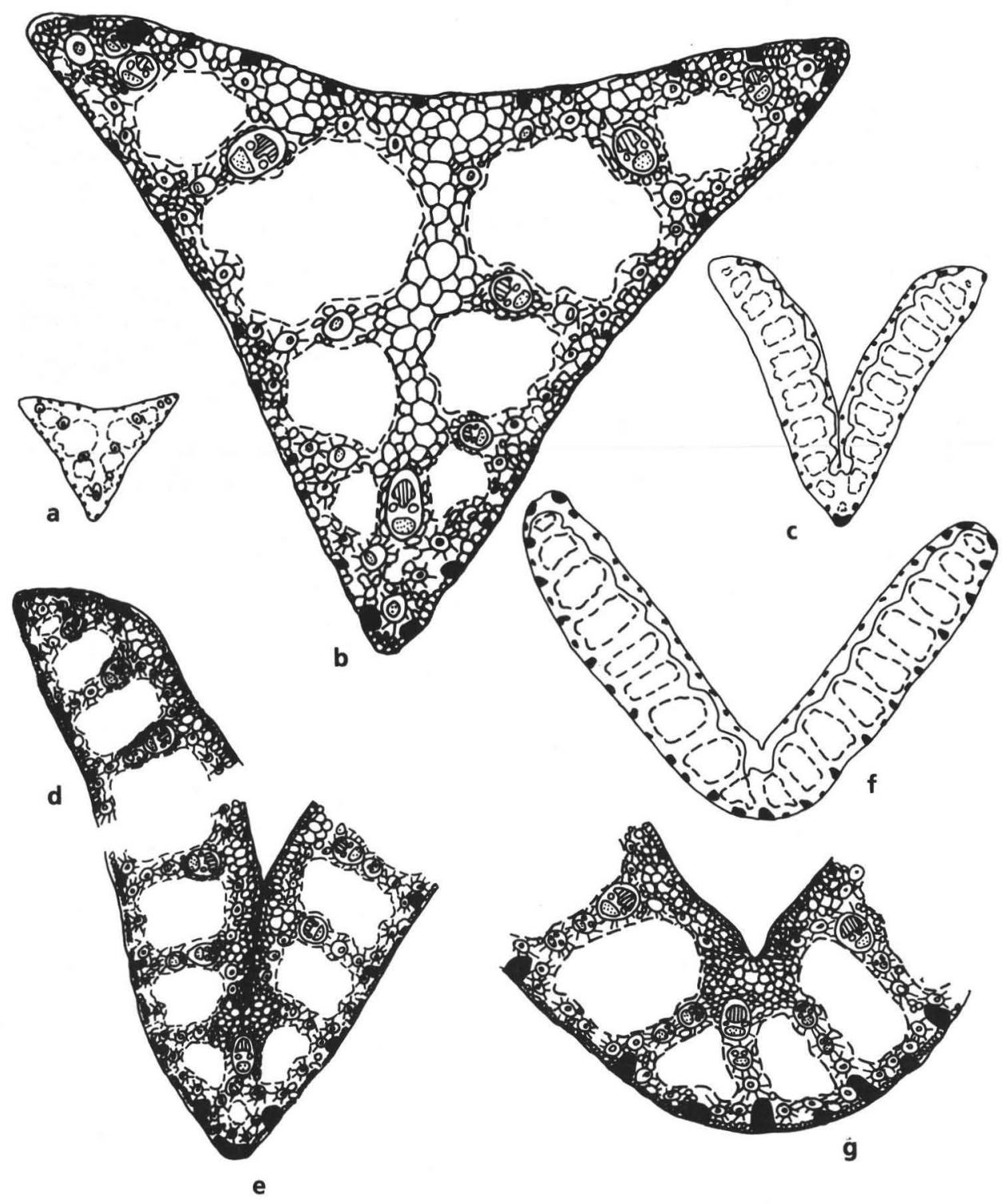

Figure 5. T.S. leaf Cyperus gunnii. a, b, Near apex; $\mathbf{c}, \mathbf{d}$, e, at halfway point; $\mathbf{f}$, $g$, near junction of lamina and sheath. Scale: a, c, f, X 35; b, X 175; d, e, g, X 90 (from Wilson 4422). 
Hypodermis. A hypodermis is always present beneath the adaxial epidermis, occasionally as only one somewhat discontinuous layer (e.g. in C. rigidellus), but usually as one to three continuous layers of thin-walled, translucent parenchymatous cells, and occasionally up to eleven layers deep in the midrib region (Figure 6a).

Sclerenchyma. All sclerenchyma is in the form of strands in Metcalfe's terminology: that is, the columns of sclerenchyma adjacent to the epidermis do not join up with the vascular bundles. There are no sclerenchyma girders (complete columns connecting the vascular bundles to one or both epidermis(es)) such as are common in other genera of Cyperaceae. In other species of Cyperus with air-cavities below the layer of

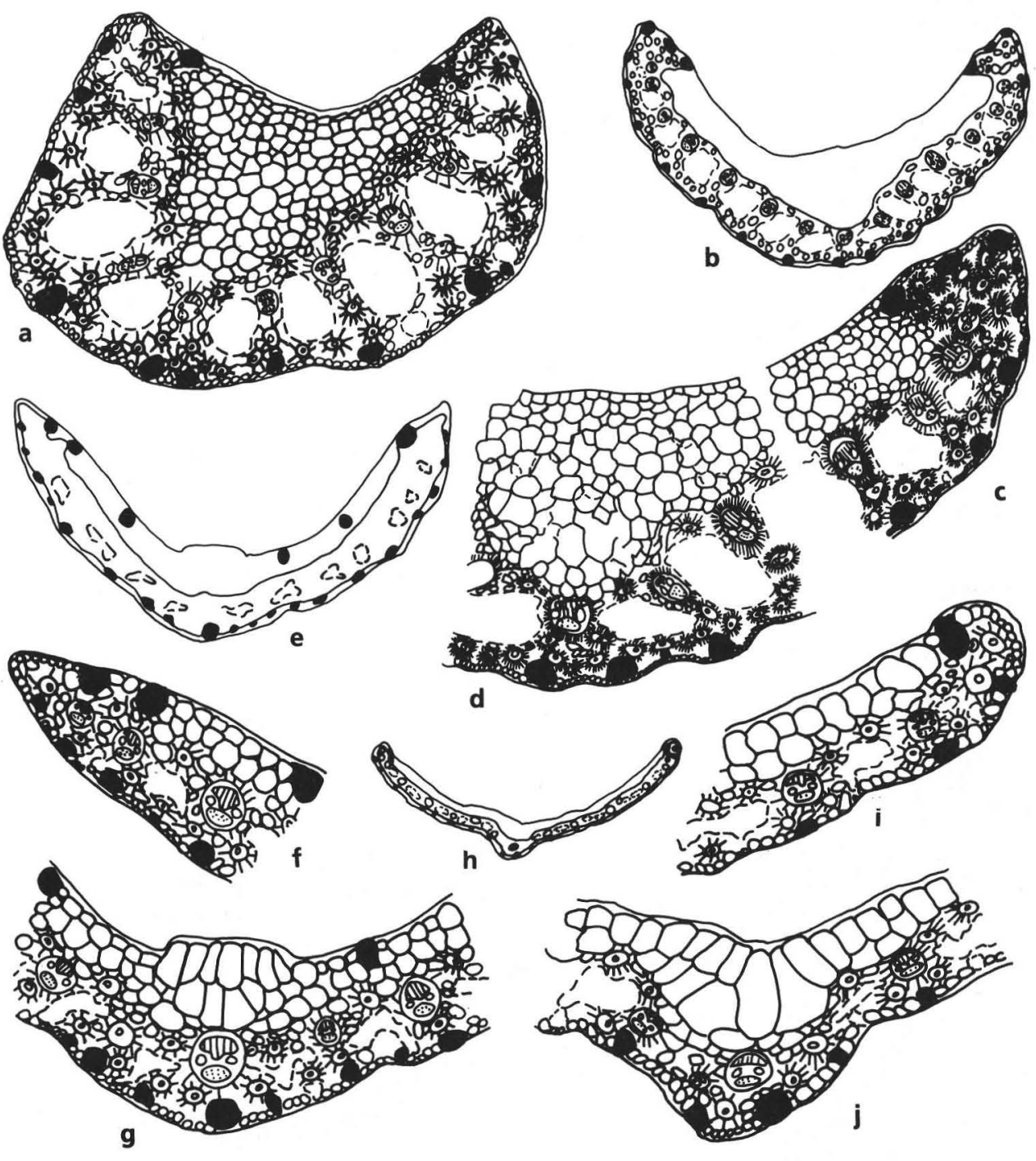

Figure 6. T.S. leaf lamina at halfway point. a, Cyperus secubans; b-d, C. ixiocarpus; e-g, C. microcephalus subsp. chersophilus; $\mathbf{h}-\mathbf{j}$, C. gilesii. Scale: a, X 90 (from Coveny 8812). b, X 35; c, d, X 90 (Latz 1255). e, X 90; f, g, X 175 (Wilson 4891). h, X 35; i, j, X 175 (Milthorpe \& Cunningham 1725). 
vascular bundles, mechanical strength is maintained by having very large vascular bundles at regular intervals spanning the width of the leaf or by having parenchymatous girders. Their place is taken in section Pinnati by 'girders' of vascular bundles.

Small sclerenchyma strands are always present near the margins of the adaxial surface, at the extremes of the chlorenchymatous tissue. As well, small sclerenchyma strands may be present immediately below the adaxial epidermis in the hypodermal layer (Figure 5). These strands are found in some species with narrow leaves but are more common in species with broader leaves (e.g. C. alterniflorus, C. betchei, C. carinatus, C. gunnii) although they are not always present then (absent from C. astartodes, C. ixiocarpus (Figure $6 \mathrm{~b}-\mathrm{d}$ ) and C. holoschoenus).

Larger strands (which are still relatively small compared to those found in other species of Cyperus) are always present adjacent to the abaxial epidermis. They regularly occur below the vascular bundle girders, and generally there are one or two strands between these as well. One to four strands are associated with the midrib region.

Midrib. This is clearly defined, both anatomically and in gross morphology, in only about half the species. However, in most species the midrib region can be recognised anatomically by a combination of at least two of the following characteristics: presence of a definite keel abaxially, bulliform cells adaxially, a forked vascular bundle girder and more numerous layers of hypodermis. This region is frequently markedly eccentric in crescentiform leaves (Figures 6a, 7a).

The midrib has associated with it a modified vascular bundle girder. This may take various forms, generally based on an inverted $Y$ shape formed by forking of the basal part of a girder abaxial to the largest (uppermost) vascular bundle in that girder. This forked vascular bundle girder is present even in thickly crescentiform leaves in which the midrib is not obvious in the outline. Often there is a secondary fork, e.g. in C. crispulus, C. cunninghamii, C. ixiocarpus (Figure 6b-d), C. lhotskyanus and C. sporobolus. In C. holoschoenus, there are two forked vascular bundle girders associated with the midrib as well as three sclerenchyma strands.

In Cyperus generally, the midrib has associated with it one extensive abaxial V-shaped sclerenchyma strand that follows the outline of the abaxial surface and often helps to form a definite keel. In section Pinnati, however, the midrib generally has one to four smaller sclerenchyma strands (not elongated laterally) associated with the forked vascular bundle girder. When there are two or four strands, the direct association with the girder is obvious. When there is one strand, it appears to be a result of two coalescing (as occurs in other Sections of Cyperus). When there are three strands, the eccentricity of the midrib is often further exaggerated: the central strand (between the forks of the vascular bundle girder) is smaller and one of the laterals becomes dominant, marked by a change in angle at that point of the abaxial outline and occasionally by scabrous epidermal outgrowths.

Vascular bundles. The arrangement of vascular bundles in leaf sheaths and blades of most species fits Metcalfe's Mariscus A-anatomy. Vascular bundle 'girders', i.e. the columns of vascular bundles lateral to an air-cavity, provide mechanical support for the leaf.

The vascular bundles are in two sizes in all leaves: one large vascular bundle sits at the top of each vascular bundle girder, while the majority of vascular bundles are markedly smaller and are found (one to three of them) abaxial to the large vascular bundle in each girder as well as along the adaxial and abaxial sides of the air-cavities. They form continous or discontinuous abaxial or adaxial layers, depending on whether the outermost ring of chlorenchymatous cells touches that of the next, or is separated from it by one or more colourless parenchymatous cells. 
Metcalfe characterised his Mariscus A-anatomy as having continuous layers of vascular bundles around the air-cavities. However, most species in section Pinnati occasionally show slight modifications of that, with the vascular bundles forming incomplete adaxial or abaxial layers around the air-cavities or with air-cavities being very small. The abaxial layer may be discontinuous in, for example, C. fulvus, C. clarus, C. isabellinus and C. perangustus, while it is the adaxial layer that is discontinuous in C. cunninghamii, C. fucosus, C. holoschoenus and C. oxycarpus. In C. gilesii (Figure $6 \mathrm{~h}-\mathrm{j}$ ), C. hesperius, C. rigidellus and C. viscidulus, both (or either) of the layers may be discontinuous. Some crescentiform leaves are small and the vascular bundles are so crowded that the pattern is not clear (there may be very few and/or very small air-cavities present). This latter condition corresponds to Metcalfe's Mariscus $\mathrm{C}$-anatomy, which is A-anatomy with air-cavities absent or very reduced. In such species (e.g. C. crispulus) at least a few small air-cavities are always present (Figure 7a, b).
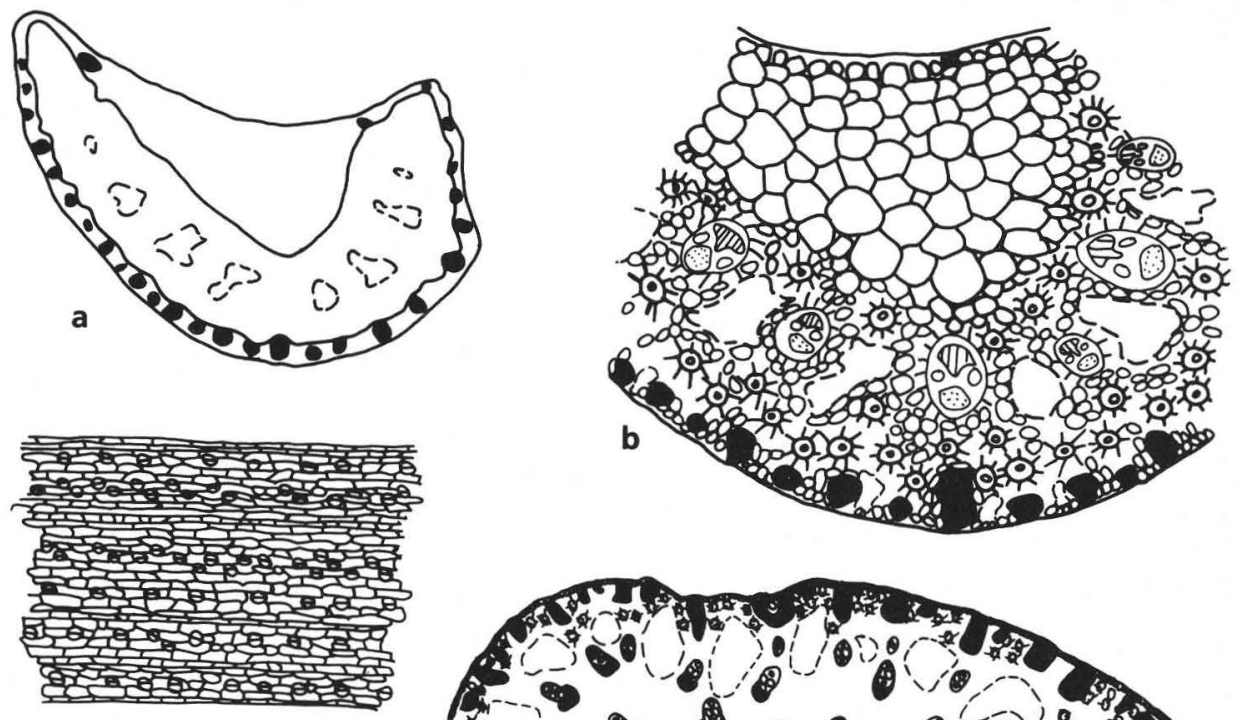

\section{c}
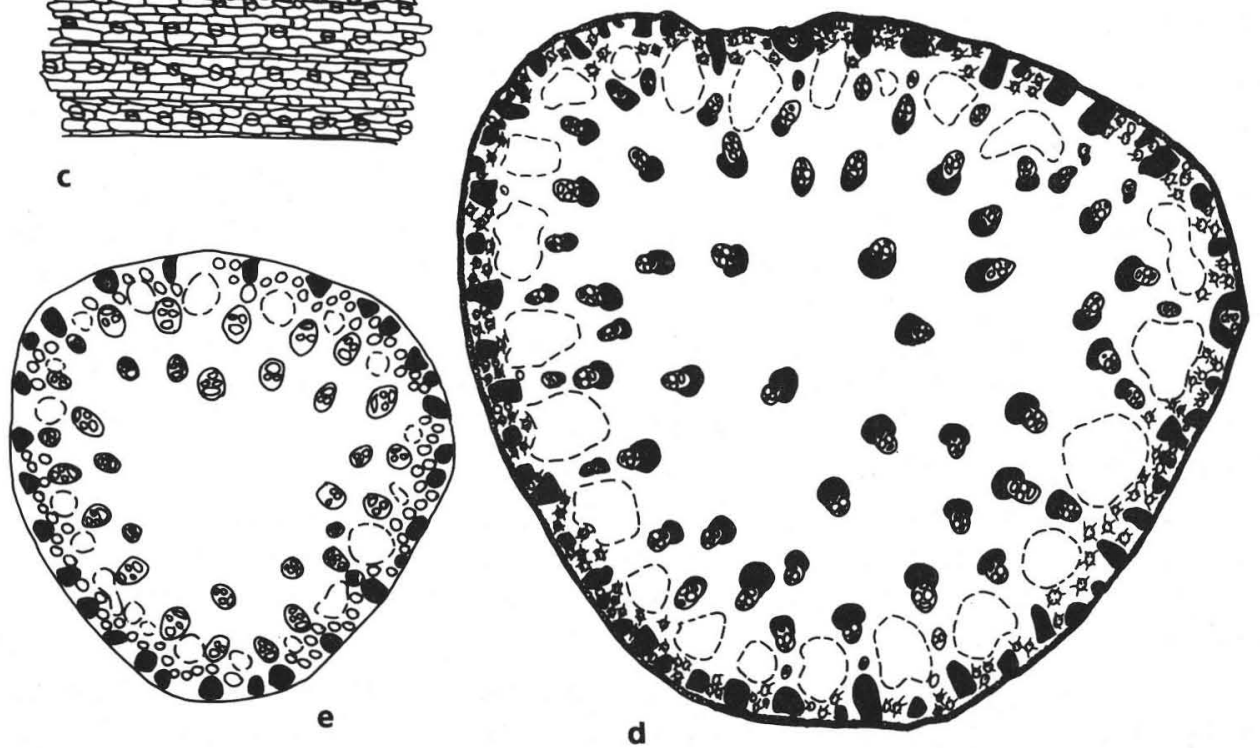

Figure 7. a, b, T.S. leaf Cyperus crispulus. c, abaxial surface of leaf C. cunninghamii subsp. cheradicus. d, T.S. culm C. lhotskyanus. e, T.S. culm C. hesperius. Scale: a, X 90; b, X 175 (from Wilson 5303). c, X 125 (Wilson 5454). d, X 25 (Wilson 5877). e, X 35 (Beauglehole 11352). 


\section{Surface view of leaf}

The leaf surface in Cyperus generally provides few characters of taxonomic use (Metcalfe 1971). In section Pinnati there is no significant variation between taxa. Epidermal cells are elongated longitudinally (that is, along the length of the leaf) and stomates occur in more or less regular longitudinal bands between the vascular strands and associated subepidermal sclerenchyma strands (Figure 7c). Silica bodies are present in some epidermal cells over sclerenchyma strands; these bodies are conical as seen in T.S. and circular as seen in surface view.

\section{Culm T.S.}

The outline is trigonous, triquetrous or terete, generally smooth, but sometimes uneven because of differential sizes of epidermal cells (C. carinatus) or scabrous epidermal outgrowths, especially near the apex (e.g. C. microcephalus and C. portaetartari). Some variation in outline may be due to the condition of the sectioned material or the technique used.

Generally, the stomates are flush with the cuticle surface. In a few species they may be slightly raised (e.g. C. cunninghamii, C. portae-tartari) or sunken (e.g. C. betchei, C. microcephalus) relative to the surface but some samples of such species have flush stomates.

The outer third of the culm has an arrangement of vascular bundles and air-cavities that I interpret as the A-anatomy of the leaf modified to conform with culm morphology (see figs. 7d, e). See also drawings of culm T.S. for C. elegans L. of section Glutinosi (Druyts-Voets 1970, her Figure 5A) and C. compactus Retz. of section Thunbergiani (Govindarajalu 1974, Figure 8D). Small-growing species have a crowded arrangement that, as with the leaves, can be interpreted as a compressed version of that found in larger species. The number of vascular bundles in a vascular bundle girder is comparable to that seen in leaves, although often one more or less (e.g. up to five per culm girder but only three or four per leaf girder in C. gunnii). Peripheral air-cavities are always present, although they are very small in some of the species with culms of small diameter, especially C. crispulus, C. gilesii, C. hesperius and C. microcephalus subsp. saxicola.

As in most Cyperus spp., the central tissue is composed of large, thin-walled parenchymatous cells that are isodiametric in cross-section but elongated longitudinally. Some species have central air-cavities (e.g. C. betchei and C. cunninghamii), apparently due to breakdown of the central ground tissue. Such cavities occur at times in all species.

All species in section Pinnati have at least a few vascular bundles scattered in the central ground tissue, generally only in the outer portion (Figure 7e). However, some species have vascular bundles scattered throughout the central ground tissue (e.g. C. lhotskyanus (Figure 7d), C. alterniflorus, C. gunnii and C. portae-tartari). The outer vascular bundles in the modified A-arrangement are a mixture of small and large as in the leaves; closer to the centre the vascular bundles are more or less evenly large in size.

Sclerenchyma is in the form of oblong, transversely oblong (i.e. relative to the culm epidermis), short-oblong, triangular, tall-triangular or broad-triangular subepidermal strands. Often these are quite rounded adaxially. As in the leaves, there are no sclerenchymatous girders. The adaxial caps on the vascular bundles are often large, especially in C. alterniflorus, C. lhotskyanus, C. oxycarpus and C. portae-tartari. Some variation in size of subepidermal strands (that is, within any one cross-section) was observed in all sections examined. 


\section{Discussion}

All species in section Pinnati (as defined here) possess A-anatomy, under my definition of the type, which is less strict than that of Metcalfe (1971). I regard the type's essential features as being (i) more than one vascular bundle per girder (except in very small leaves), (ii) presence of adaxial and abaxial layers of small vascular bundles around the air-cavities, and (iii) adaxial epidermal cells of similar size (1-2X) to the abaxial. Incompleteness of the adaxial and abaxial layers of small vascular bundles and size of air-cavities seem of less importance, considering the intraspecific variation seen in sect. Pinnati and in species in other Sections, such as C. oxylepis and C. trachysanthos of sect. Glutinosi. The physiological significance of this unusual type of anatomy is not clear: it may be related to photosynthetic efficiency (see page 391).

A-anatomy is found only in sections Pinnati, Glutinosi, Thunbergiani and Turgiduli p.p. (see further detail on page 398 et seq.). The other, and by far the most common, anatomical arrangement in Cyperus sens. lat. (not found in sect. Pinnati) of vascular bundles in a single lateral row, and with the adaxial epidermal cells much larger than the abaxial cells, was termed B-anatomy by Metcalfe. He used the term C-anatomy to describe a modification of A-anatomy in which air-cavities are much reduced or absent but I would regard this as fitting within the range of A-anatomy.

Study of many species in Cyperus sens. lat. suggests that A-anatomy is advanced, in line with morphological features of such species, compared to the B-anatomy and its variants found in most Cyperus spp. with Kranz anatomy. Anatomical variants are known (Wilson and Johnson unpubl.) that may represent intermediate stages or parallel developments, for example, some Pycreus species have the adaxial and abaxial epidermal cells more or less the same size (a feature of A-anatomy) although the anatomy is otherwise of the B-type.

The distinctive A-anatomy is useful in distinguishing species belonging to sections Pinnati, Glutinosi, Turgiduli and Thunbergiani from the rest of Cyperus. Morphological features must then be used to distinguish between these Sections. Whether this anatomy is a synapomorphy for these groups or represents parallel developments is not clear.

In various other monocot groups, such as Juncus sect. Genuini (Edgar 1964, Johnson ined.) and Mesomelaena (Wilson 1981b), anatomical features are distinctive for a species or for small groups of closely related species. In sect. Pinnati, features are indeed generally consistent within a species, given samples of comparable age and relative position (cf. the differences between immature and mature leaves of $C$. orgadophilus, Table 2). However, interspecific variation is not sufficiently great to be useful in identification at or below the specific level in this Section.

\section{Phytochemistry}

\section{Introduction}

Secondary metabolites are amongst the biochemical characters that have been used in plant taxonomic studies (Harborne \& Turner 1984). Formerly thought to be waste products, secondary metabolites are now considered to have a functional role in defense, pollination, energy storage and fruit dispersal (Levin 1976, Cronquist 1977), although these roles are not yet fully understood (Gershenzon \& Mabry 1983). One taxonomically interesting group is the pigments, including betalains, quinonoids, carotenoids and flavonoids (anthocyanins, and yellow and colourless flavonoids). Of these, the flavonoids have been much used, mostly at lower levels of classification. Their general usefulness at higher taxonomic levels is uncertain, although comparison of flavonoids at familial level do show differences (see, for example, Williams \& 
Harborne (1975) and Gornall et al. (1979)). Disagreement remains over homologies and degree of advancement of particular flavonoid types. Harborne (1980) says there is a single biosynthetic pathway for any flavonoid in any species, but others disagree: Stuessy \& Crawford (1983) suggest that Harborne is correct only so far as the basic steps are concerned and that the later steps may be variously regulated. Gornall \& Bohm (1978) point to a secondary trend to reduction in complexity, that is, 'simple' flavonoids may be primitive or very advanced.

\section{Flavonoids in section Pinnati}

Flavonoids in the leaves and inflorescences of most species of section Pinnati were surveyed by Harborne et al. (1982, 1985), a total of 36 samples representing 28 species and subspecies. One species of the American section Glutinosi, C. oxylepis Nees, was analysed for comparison (Harborne and Williams unpubl.).

Generally, the flavonoids in section Pinnati conform to the pattern found in Cyperus sens. lat. except that:

(i) the aurone mariscetin is much more common (in 12 species; only found in seven other species of Cyperus);

(ii) the flavonol-derived quercetin and kaempferol methyl ethers are more common than in Cyperus generally (in leaves; none was found in inflorescences); and

(iii) $7,3^{\prime}, 4^{\prime}$-trihydroxyflavones were found in four species (only found in three other species of Cyperus).

Flavonol methyl ethers are mostly known elsewhere from bud exudates and leaf wax deposits and are relatively rare in the monocots (Wollenweber \& Dietz 1981). Correlation with exudates is not certain in this case, since two of the most viscid species in section Pinnati (C. ixiocarpus and C. viscidulus) were not found to contain flavonol methyl ethers. The exudates in species of sect. Pinnati have yet to be characterised (they are soluble in absolute alcohol but not in water).

The widespread occurrence of aurones (especially in inflorescences) is the most distinctive flavonoid feature of the family Cyperaceae, the most common aurone being aureusidin. In Cyperus sens. lat., three other aurones have been found: mariscetin, leptosidin, and an uncharacterised aurone in the South American species $C$. reflexus Vahl. Section Pinnati is distinctive in the genus in having mariscetin in twelve species. Mariscetin is otherwise only known in eight species, scattered in seven Sections (Harborne et al. 1982). Of these eight species, three are confined to Australia, four are more widespread and one, C. oxylepis in section Glutinosi, is confined to South America. The close morphological similarity between species of the sections Pinnati and Glutinosi suggests that it would be of interest to analyse other species of the latter for flavonoids.

\section{Quinones}

Quinone pigments are widespread in living organisms but individual compounds tend to have a restricted distribution, which may make them useful taxonomically (Mathis 1966). Allan et al. (1969, 1978) surveyed the roots and rhizomes of 107 Australian species in 29 genera of Cyperaceae. Quinones were restricted in their sample to about half the species of Cyperus sens. lat. (including Remirea and the three species sampled in sect. Pinnati), as well as one species of Fimbristylis and Schoenoplectus articulatus (as Scirpus articulatus). Within Cyperus, they sampled widely and found eleven types of quinone. The single quinone found in sect. Pinnati also occurred in species of other Sections. Unfortunately, as with certain other studies, the significance of these results is not clear because the vouchers could not be located with certainty in the herbarium of the Botany Department, James Cook University. 


\section{Photosynthetic types}

Besides my anatomical study of all species in sect. Pinnati, about twelve species (the number is uncertain owing to doubtful identifications of some vouchers) have been examined either biochemically or anatomically by others (Raynal \& Lerman ined., Carolin et al. 1977, Takeda et al. 1985). These studies confirm that all species in this Section possess the $\mathrm{C}_{4}$ type of photosynthesis, as do numerous other groups within Cyperus sens. lat. This type is characterised anatomically as Kranz anatomy of the chlorocyperoid type (that is, with two sheathing layers around the vascular bundles: the outer a mestome sheath, the inner a bundle sheath of Kranz cells) and biochemically as NADP-ME type (Raynal 1972, 1973; Carolin et al. 1977, Ueno et al. 1988).

The $\mathrm{C}_{4}$ pathway is strongly correlated with a set of environmental conditions different from those associated with the $C_{3}$ pathway (Ray \& Black 1979): high light intensity (non-saturating light growth curves), high temperatures, and cold-sensitivity. Tolerance of salinity, low nitrogen levels and probably also efficiency of water use are other features of $\mathrm{C}_{4}$ plants. All these conditions are generally found in the hotter and drier parts of the world.

Takeda et al. (1985) found that $C_{4}$ species of Australian Cyperaceae favoured the tropical and subtropical savannas of northern Australia and hot dry areas with summer rainfall, whereas $C_{3}$ species were more common in cooler regions with a winter rainfall maximum, a situation grossly similar to that found by Hattersley (1983) in Australian grasses. Species of section Pinnati are, indeed, most common in northern and central Australia (Figure 8) and uncommon in the southern winter-rainfall regions of Australia. Features such as efficient water use have no doubt been important in allowing such species as C. cunninghamii, C. microcephalus and C. crispulus to grow in dry, rocky habitats where the other most common herbaceous plants (in terms of numbers of individuals) are the $\mathrm{C}_{4}$ hummock grasses, species of Plectrachne and Triodia.

The photosynthetic significance of Metcalfe's A-anatomy found in vegetative parts of species of section Pinnati is not known. However, a function may be postulated similar to that suggested for grasses by Hattersley (1984). In $\mathrm{C}_{4}$ grasses, the specialised Kranz chlorenchymatous cells (the photosynthetic carbon reduction or PCR tissue) around the vascular bundles are separated from air cavities by a ring of radially arranged mesophyll (primary carbon assimilation or PCA tissue). It is thought that this arrangement helps maintain high $\mathrm{CO}_{2}$ levels in the PCR tissue and thereby improves photosynthetic efficiency. A comparable study has not been done for Cyperus. However,it is postulated that A-anatomy may give maximum exposure of PCA tissue to the intercellular air-cavities while limiting contact between those cavities and PCR tissue, thereby ensuring maximum gas exchange while maintaining a high $\mathrm{CO}_{2}$ content in the PCR tissue. This remains to be tested.

\section{Distribution and ecology}

\section{Distribution}

Most species in sect. Pinnati are endemic to Australia, with only three also recorded sporadically in southern New Guinea. C. gunnii subsp. gunnii has been collected once in the Bay of Islands region of the North Island of New Zealand, in about the same latitude as Sydney. Healy \& Edgar (1980) regard this occurrence as adventive. A few casual introductions have been identified amongst the numerous wool-alien species in continental Europe and England (Probst 1949 - specimens identified by Kükenthal; 
Ryves 1976). Generally these wool-aliens do not persist in Europe and their occurrence is of curiosity value only.

Within Australia, sect. Pinnati is widespread (Figure 8) in summer-rainfall regions and south-eastern Australia. There are no species in the extreme south-west of Western Australia, the Nullarbor region, rain forests and alpine regions. The few records for Cape York Peninsula probably reflect lack of collecting rather than absence. Concentrations of species are found in the Pilbara, northern and central Australia, and subtropical eastern Australia (Queensland and the northern half of New South Wales) where there is a wide range of habitats. The Pilbara is regarded as a phytogeographic refugium at the south-western limit of the summer rainfall zone and with a relatively high number of endemic taxa in its flora (Burbidge 1959, 1960). C. hesperius is the only species of sect. Pinnati endemic to the Pilbara. The map does not adequately represent the range of species found in the Pilbara: ten species occur there, but have been collected only sporadically, hence the low numbers of species per grid-square.

\section{Ecology}

The warmer and more arid regions have more species of sect. Pinnati than the cooler and/or high rainfall areas: only $C$. gunnii subsp. gunnii is found in Tasmania.

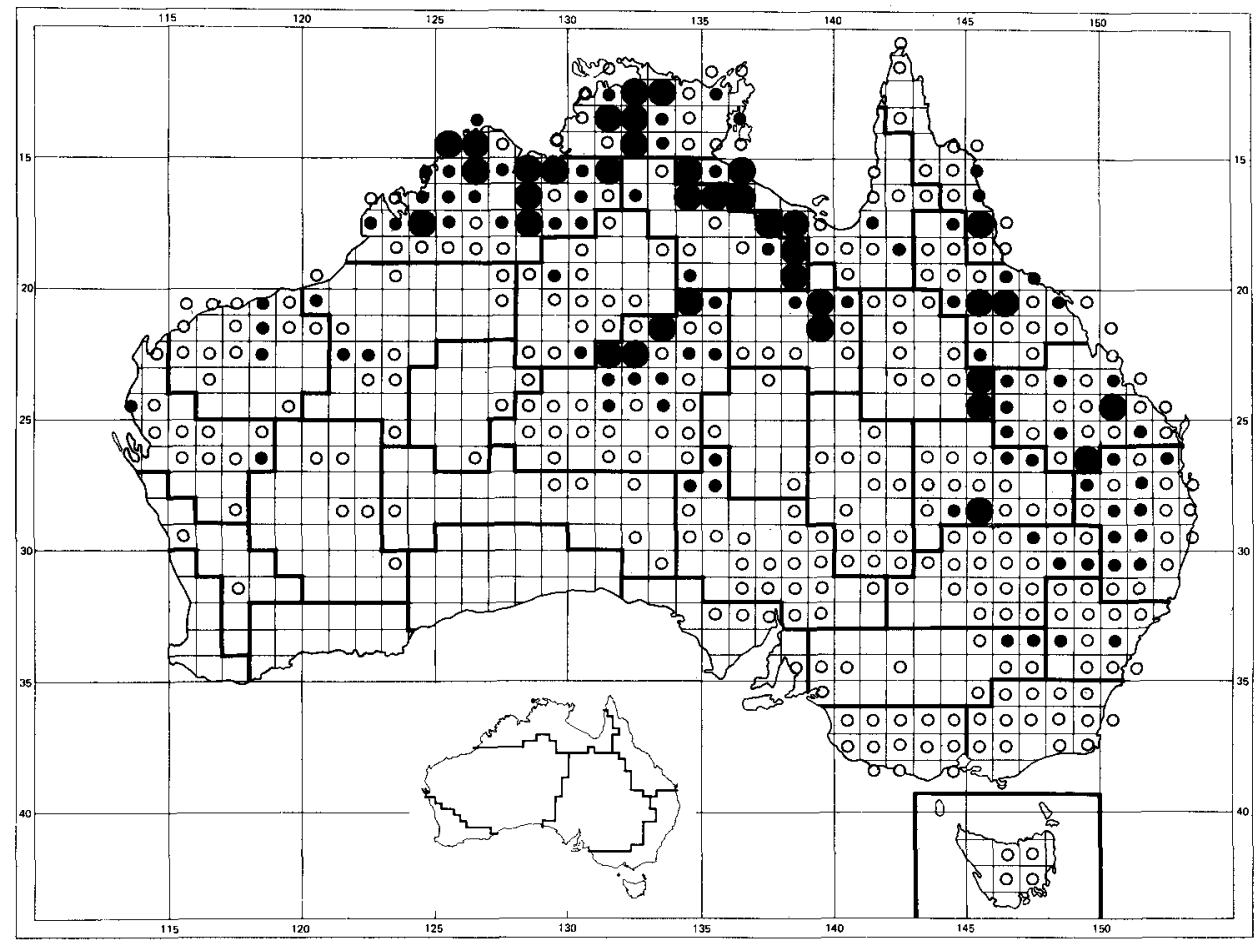

Figure 8. Number of taxa (species and subspecies) of section Pinnati recorded for each degree gridsquare. The groupings emphasize the concentration of taxa in the Pilbara, northern and central Australia and subtropical eastern Australia. Small open circle: 1-2 taxa per grid-square; small closed circle: 3-4 taxa; big closed circle: 5-12 taxa. Base map shows natural regions of Barlow (1986). 
Only C. gunnii subsp. novae-hollandiae grows in more or less permanently wet situations, on the margins of Melaleuca quinquenervia swamps. Other taxa grow in association with more ephemeral waters or in dryland habitats. C. centralis, C. ixiocarpus and C. cunninghamii subsp. cheradicus grow, often forming robust tussocks, in the sandy or stony beds or on the lower banks of inland streams, where they would be inundated only relatively briefly. Taxa such as C. gunnii subsp. gunnii, C. viscidulus and C. alterniflorus are similarly found on the banks of streams and billabongs, often in slightly wetter situations. The banks of man-made water supplies (roadside drains, ground tanks, gravel pits, etc.) are colonised by C. oxycarpus, C. holoschoenus, C. dactylotes, $C$. betchei and C. gunnii.

The various forms of $C$. microcephalus are all associated with dry rocky habitats: subsp. microcephalus on scree slopes below rock-faces and amongst boulders, subsp. chersophilus with hummock grasses on rocky hillsides, and subsp. saxicola in crevices on rock-faces and rocky outcrops. Other taxa in dry rocky habitats are C. cunninghamii (except subsp. cheradicus), C. crispulus and C. astartodes. C. secubans is found on rocky outcrops in the Nandewar Range of eastern N.S.W. but usually along seepage lines.

Woodland and grassland species tend to be drought-evading, i.e. the plants are capable of dying back to a basal tussock in the dry season and later shooting again. C. orgadophilus, C. sexflorus and C. sporobolus have definite underground bulbous bases, which may enable these species to survive the frequent fires of their tropical open forest habitat. The bases of C. blakeanus are somewhat bulbous: fire and seasonal water shortages are also features of the open woodland and shrubland habitats of this species. In eastern Australia, C. fulvus and C. perangustus are in forest or woodland habitats. $C$. clarus is restricted to grasslands or open woodlands on deep clay soils. C. isabellinus is similarly restricted to clay soils, in this case the gilgaied cracking clays associated with brigalow scrub.

C. gilesii, C. rigidellus and C. isabellinus are the only usually annual species (they may also be short-lived perennials) and they are found in the more arid and southerly inland regions. These species are capable of growing in a wide range of habitats, but usually associated with ephemeral puddles of water.

Cyperus fulvus (a woodland species) and C. angustatus and C. holoschoenus (both found in seasonally swampy sites) have been collected a few times in the southern lowlands of New Guinea. Webb \& Tracey (in Walker 1972) suggest that the open sclerophyll formations of New Guinea represent a recent colonisation from Australia. Similar distribution patterns across Torres Strait are found in other families (Walker 1972), as well as in other species of Cyperaceae, e.g. Cyperus aquatilis, Fimbristylis furva and F. recta.

\section{Taxonomy}

\section{Taxonomic history}

The first species in this group were described by Robert Brown (1810) from material he collected at Shoalwater Bay (C. alterniflorus), on the East Coast of Queensland (no more specific locality given: $C$. fulvus), from North Island in the Sir Edward Pellew Group in the Gulf of Carpentaria ( $C$. holoschoenus and C. microcephalus), from Morgans Island in Blue Mud Bay (C. sporobolus), in the Gulf of Carpentaria (no more specific locality given: $C$. sexflorus), and on the North Coast (probably Arnhem Bay or neighbouring islands: $C$. angustatus and $C$. carinatus). It is surprising that Brown did not 
name the species subsequently published as C. gunnii by Hooker (1858). Brown apparently did collect a specimen of it at Port Jackson and gave it the manuscript name of $C$. scaber (Bentham 1878) but did not publish it. This would be the specimen cited by Kükenthal (1935-36) under C. gunnii as 'Port Jackson, R. Brown 5924!' but it cannot be found now in $\mathrm{BM}$ or $\mathrm{K}$.

The majority of species occur in tropical or inland Australia so it is understandable that relatively few specimens were collected or species described after Brown's visit until well into this century. Confusion and misapplication of names has been common, as will be evident from the synonymies and notes for each species.

Poiret (1817) and Sprengel (1824) listed the species described by Brown but added no new taxa. Kunth (1837) described $C$. sieberi (= C. fulvus). Nees (in Lehmann 1846) misapplied the name $C$. carinatus to a specimen of $C$. congestus Vahl, apparently an introduction from southern Africa to Western Australia in the early days of that colony. He presumably did not have access to Drummond's Third Collection of specimens, which were not despatched to Hooker until August 1844 (Erickson 1969: 168). This collection included a specimen of $C$. alterniflorus, the only species of sect. Pinnati found in south-western Western Australia (and then only on the north-eastern fringe of that region). C. alterniflorus had been described by Brown from Queensland, at the opposite end of its distribution. This western specimen, Drummond Coll. III no. 335, was the basis of Steudel's C. pictus (1854). Steudel apparently had not seen material of any of Brown's species since he included them in his section of 'Species quoad sectiones priores partim omnino dubiae'.

Hooker (1858) described C. gunnii, the only species found in Tasmania. Boeckeler described several new species from specimens sent to him by Mueller and Amalie Dietrich: C. novae-hollandiae (1870; now regarded as a subspecies of C. gunnii), C. ochroleucus $(1875 ;=C$. fulvus) and C. lhotskyanus (1884). These species and previously described species of this group (C. sieberi, C. angustatus, C. carinatus, C. gunnii) were scattered amongst four of his nomenclaturally informal and rather uncritical groups in Section Eucyperus. Assessment of Boeckeler's species is difficult since (i) he cited specimens only in very general terms, and (ii) only part of his herbarium (in B) survived the bombing of World War II.

Despite having material available to him in MEL of several new taxa that were subsequently described by others, Mueller described only one new species and one variety in this group (C. ixiocarpus, Mueller 1886; C. umbellatus var. fasciculigerus, Mueller in Tate 1896).

Bentham (1878) made a good synthesis of available literature and specimens in his 'Flora Australiensis' treatment. He described C. dactylotes, C. gilesii, and C. gracilis var.? rigidella (p.p. $=$ C. rigidellus). In his synoptic key to Cyperus, most of the species now included in section Pinnati were put in his informal group Fulvi, the rest in the informal Lucidi with several other species. As with Boeckeler's groupings, Bentham's were of unspecified rank (and indeed not all species were placed in groups) and hence are of no significance nomenclaturally.

Moore and Betche (1893) formally established C. gunnii as a variety of C. lucidus, a species in sect. Thunbergiani. In this they were following Mueller (1874).

C.B. Clarke (1884), in his paper on the Cyperus species of India, was the first to consistently use sectional names in Cyperus that are nomenclaturally acceptable today. The only species of sect. Pinnati mentioned in that paper was $C$. sieberi $[=$ C. fulvus], which he placed doubtfully (following Boeckeler) in sect. Glomerati. Clarke concentrated on the African and Indian species of Cyperaceae and paid relatively little attention to Australian species, at least in print (the specimens in $\mathrm{K}$ are exten- 
sively annotated). Two extracts from his massive manuscript monograph of the family were published posthumously. The 'Illustrations' (Clarke 1909) included only C. fulvus of sect. Pinnati (as Mariscus fulvus). In the 'New Genera and Species of Cyperaceae' (Clarke 1908) were described C. laetus (= C. fulvus), Mariscus cunninghamii, $M$. rutilans ( $=$ C. lhotskyanus) and $M$. rigidellus (based on $C$. gracilis var. ? rigidella Benth.). In addition, combinations under Mariscus were made for $C$. alterniflorus, C. gunnii, C. fulvus, C. angustatus, $C$. holoschoenus and C. carinatus. Clarke placed the species currently put in sect. Pinnati in four different sections (with other species) in Cyperus sens. strict and Mariscus. This was the first time that species of this section had been treated as belonging in the segregate genus Mariscus. Unfortunately, being a mere extract from his monograph, the work included no discussion of relationships or morphology.

Domin (1915) also recognised the segregate genus Mariscus, describing Mariscus xerophilus and $M$. aridicola, and making the combination $M$. fasciculigerus (all three names are synonyms of $C$. cunninghamii). He reduced $C$. novae-hollandiae to varietal rank under $M$. gunnii and described several varieties in the variable species $M$. fulvus. He obligingly provided alternative names under Cyperus for his new species - a practice since outlawed by the International Code of Botanical Nomenclature - 'im Sinne der Merzahl der australischer Botaniker, welche die Gattung Mariscus nicht anerkennen'. The segregate genus Mariscus is still generally not accepted, and not only by Australian botanists.

The period 1916-1931 saw a series of largely uncritical regional Flora treatments. Maiden and Betche (1916) made the combination under Cyperus for Mariscus rutilans; Fitzgerald (1918) described C. holoschoenus var. viscidus (= C. astartodes); Black (1924) described C. clelandii $(=C$. dactylotes) and made the combination under Cyperus (1929) for $M$. rigidellus; Gardner (1930) made the combination under Cyperus for M. cunninghamii.

Kükenthal (1931) described C. subpinnatus and its variety subrigidellus, both of which are here regarded as belonging to C. rigidellus. In his impressive revision (1935-36) of the genus Cyperus sens. lat. he set up the section Pinnati in subgenus Mariscus to include many of the species here placed in this Section. However, a few species here considered as belonging to sect. Pinnati were placed by him in sections Thunbergiani and Turgiduli (with other species). He described no new species but made several new varieties under C. fulvus, as well as making combinations in Cyperus for Domin's varieties under Mariscus. In addition, he reduced C. sexflorus and C. microcephalus to varietal rank under $C$. sporobolus.

Sectional names used in this paper are those of Kükenthal (1935-36), to enable ready reference to his work, since it is the only recent revision of Cyperus sens. lat. The limits of Sections as I currently recognise them often differ somewhat from Kükenthal's; these deviations are mentioned where relevant, e.g. on page 398 et seq. Some of Kükenthal's names should be replaced by earlier sectional names if the current International Code of Botanical Nomenclature is strictly followed. However, this is a part of the Code that I feel should be amended in line with the proposal by Johnson, Briggs \& Blaxell (1981). Despite its rejection at the Berlin International Congress, this proposal would save much time currently wasted in searching old and obscure publications for sectional names.

Kükenthal's last contribution to the species under consideration was the description (1940a) of a robust specimen of $C$. holoschoenus from New Guinea as var. fuscisquamatus. Blake (1940) elevated C. betchei to specific rank, synonymised C. clelandii with $C$. dactylotes and $C$. ochroleucus with $C$. fulvus, and described two new species, C. clarus and C. oxycarpus. Further contributions were on the South Australian species 
(Blake 1943), on C. ixiocarpus and C. cunninghamii (1947a), and on the few New Guinea records $(1947 \mathrm{~b}, 1954)$. As well as providing an amplified description of C. ixiocarpus, Blake set up sect. Ixiocarpi to accommodate this species. The only nomenclaturally significant point in recent Flora treatments is the selection (without discussion) of C. angustatus as the lectotype of sect. Pinnati by Kern (1974). Wilson (1980) described C. portae-tartari and C. viscidulus.

\section{Relationships}

\section{Relationships within sect. Pinnati}

Section Pinnati is characterised by a combination of subdigitate or shortly spicate arrangement of spikelets in clusters, the A-type vegetative anatomy (Metcalfe 1971) or modifications thereof, and the variety of dispersal units even within a species (from individual flowers to whole partial inflorescences). In addition, quinone types and the frequency of the aurone mariscetin may be distinctive. It should, however, be remembered that mariscetin has also been found in sect. Glutinosi (and sporadically in other Sections) and that A-anatomy is also found in sections Glutinosi (=Viscosi), Thunbergiani and Turgiduli (= Pennati). The mainly American sect. Glutinosi is the group probably most closely related to sect. Pinnati; the other two sections are less close. Confirmation (or otherwise) of the monophyly of the Section must wait until other parts of the genus are thoroughly reviewed.

Putative relationships within the Section, based on morphology and vegetative anatomy, are reflected in the species order used in the taxonomic treatment (as far as this is possible in a linear sequence). There are several groups of species that share character states, with a few other species not particularly close to any one group but nevertheless apparently more closely related to species of this Section than to those of other Sections.

Species 1-11 (C. cunninghamii to C. blakeanus) form one loose group of species in the wet/dry tropics to arid-zone. These are mostly small slender species, shallowly rooted, with leaves mostly not obviously septate-nodulose. They have more or less shining, stramineous to dark brown glumes (rarely dark red-brown and then not as shining as in C. gunnii and its allies), with the midrib straight to excurved as seen in side view, and with thick lateral nerves. Unlike most other species of sect. Pinnati, nearly all those in this group have the nut falling separately from the glume, notable exceptions being C. cunninghamii with its mostly inrolled glumes and C. crispulus with its often viscid spikelets. The anthers tend to be short in this group but with a long apical appendage. Species 2-6 (C. astartodes to $C$. sexflorus) form a more closely related subgroup, with glumes of similar shape, and red-brown to black (mostly tuberculate) nuts that generally are as long as or exceed the glumes. C. portae-tartari (sp. 7) resembles these species (especially C. microcephalus subsp. microcephalus) in glume shape and general habit, but differs in having a broader nut and often having prickles on the glume midrib. In these latter characters it resembles $C$. cracens and is assigned with that species to a second subgroup that also includes $C$. orgadophilus and $C$. sporobolus, all sharing a similar glume shape and similarly dense, small spikelet clusters. These subgroups are neither exclusive nor necessarily indivisible further: for example, C. cunninghamii does not fit in either subgroup described above, because of its often terete and viscid spikelets with very broad rachilla wings and large glume spacing, but it does share other character states with C. astartodes and C. hesperius in the first subgroup. Similarly, $C$. microcephalus, $C$. hesperius and $C$. crispulus share the unusual character state of a thickened rachilla. $C$. orgadophilus, $C$. sexflorus and $C$. sporobolus have markedly bulbous bases but differ in many other characters. 
Species 12, C. angustatus, stands out as the only species in the Section with an elongated, slender rhizome. It is a slender perennial of the wet/dry tropics. It is similar to $C$. microcephalus in glume shape and has nuts relatively long compared to the glume (and generally falling separately from the glume), but the soft texture of the rather dull glumes and the pale, smooth nut resemble those of $C$. carinatus and its allies, or to some extent those of $C$. perangustus.

Species 13, 14 (C. ixiocarpus and C. viscidulus) are perennials of the arid zone to wet/ dry tropical region, but they are more robust than spp. 1-11, tend to be deeply rooted, have more or less strongly septate-nodulose leaves, and usually occur in habitats at least seasonally wetter. Their spikelets are usually strongly viscid, so that the nut falls with the glume even though the glume margins are not inrolled. Glumes are stramineous, not very shining (when not viscid), broad, with thick nerves close to the midrib. Nuts are broad-obovate to elliptic and dark red-brown to black in both species, but differ in surface texture.

Species 15-17 (C. carinatus to C. oxycarpus) are robust wet/dry tropical species and, like species 13 and 14, are found in wetter habitats. They form big shallow-rooted tussocks and tend to have strongly septate-nodulose leaves ( $C$. oxycarpus less so). Although septate-nodulose, the leaf bases are relatively smooth and shining. Inflorescences are big and open, with long branches, small spikelet clusters and shortish spikelets. The glumes are pallid to stramineous, often blotched with yellow or red, dull, incurved or straight along the midrib as seen in side view and are of a soft texture compared to, say, C. gunnii or C. cunninghamii. Nuts are pale yellow-brown to pale red-brown, very narrow-elliptic to narrow-ovate, with a smooth or colliculate surface. The nut of $C$. carinatus is very similar to that of $C$. orgadophilus.

Species 18-20 (C. betchei, $C$. dactylotes and C. fucosus) are also robust, more or less deeply rooted and septate-nodulose perennials, often with shining leaf bases. They are found in seasonally wet habitats in the tropical to subtropical and arid zones. They differ from spp. 15-17 in their glumes, which are firmer textured and shining, bright yellow to dull red-brown in colour, straight to incurved, with moderately thick nerves. Anthers range from short to long, with a short appendage. Nuts are yellowbrown, narrow-elliptic to narrow-ovate, with a smooth or colliculate surface.

Species 21-24 (C. gunnii to C. centralis) constitute a group of temperate to arid zone perennials (except for $C$. gunnii subsp. novae-hollandiae, which is restricted to the tropical east coast). They are mostly deep-rooted and tall (except $C$. lhotskyanus) with striate, dull leaf bases and septate-nodulose leaves. Their glumes are generally bright or deep red-brown, strongly shining, more or less firm-textured, with fine nerves. Anthers are longish, with a short appendage. The nuts are generally pale, slender, with a smooth or colliculate surface (tuberculate in C. alterniflorus).

Species 25 C. secubans, a small perennial from the Nandewar Range, has glumes similar to the preceding group, but resembles the following group in vegetative features.

Species 26-31 (C. isabellinus to C. gilesii) are a group of smallish, subtropical to aridzone annuals or short-lived perennials of drier habitats. Leaf margins bear erect, blunt prickles or a mixture of types but not regularly antrorsely aculeate prickles. Leaf bases are striate and dull. Glumes have an incurved or straight midrib in outline, and are generally yellow to golden-brown (stramineous with red-brown blotches in C. rigidellus), shining, moderately firm-textured, with thick nerves and often with a long and excurved mucro. Rachilla wings are very narrow. Anther appendages are short. Species 26 and 27 (C. isabellinus and C. rigidellus) form a subgroup characterised by the pale yellowish, narrow-obovate to narrow-elliptic nut, which is generally smooth or colliculate (occasionally tuberculate in C. rigidellus). Species 28-30 (C. clarus to 
C. perangustus) form another subgroup, being similar in gross appearance and glume shape. $C$. fulvus and $C$. perangustus also have in common the spicate clustering of spikelets and the smooth to colliculate nut. C. clarus and C. fulvus have obovate nuts, C. perangustus narrow-obovate. C. gilesii shares the general group characteristics but is unique in its long, narrow glumes and very narrow-elliptic nut with red-brown to black, mostly tuberculate, surface.

Species 32, C. latzii, is another species that does not fit into any of the subgroups yet still has the general characters of sect. Pinnati. It is a smallish short-lived perennial of drier (but still seasonally wet) tropical savanna habitats, characterised by very excurved, variably red-brown to yellow-blotched, glistening glumes with a much-thickened midrib and very thick nerves close to the midrib. Its red-brown nut is of the fairly widespread narrow-elliptic to narrow-obovate shape, and is variably smooth to colliculate or foveate. Its glumes show some resemblance to those of C. blakeanus.

Relationships with other Sections in Cyperus sens. lat.

Kükenthal (1935-36), in erecting sect. Pinnati, in subgenus Mariscus, commented: 'Species inter Laxiglumos et Thunbergianos quasi intermediae'. He accordingly put sect. Pinnati between sections Thunbergiani and Laxiglumi in his sequence, and placed in sects. Thunbergiani and Turgiduli (= Pennati) several species that are here included in sect. Pinnati. Although sections Pinnati and Thunbergiani are related, I believe that sect. Pinnati is phylogenetically closest to sect. Glutinosi, which Kükenthal (erroneously in my opinion) placed distant from these Sections, in his subgenus Eucyperus. As long ago as 1874 the intermediate position of such species between Cyperus and Mariscus was recognised by Mueller: 'C. Holoschoenus a Cyperis genuinis transitum ad eos sectionis Marisci efficit' (1874: 268). The above-mentioned Sections bridge the traditional boundaries of Cyperus sens. strict. and Mariscus.

Brief notes follow on the various Sections that have been suggested as allies of sect. Pinnati, outlining their features and differences from sect. Pinnati. Most need more detailed revisionary study. Deviations in delimitation and nomenclature from Kükenthal (1935-36) are indicated.

Sect. Glutinosi Boeck. ex Kük. (= sect. Viscosi C.B. Clarke on priority). A Section of about six species in North, Central and South America, extending to eastern Pacific and Caribbean islands. I exclude C. constanzae Urban and C. gardneri Nees from this Section: they have $\mathrm{C}_{3}$ (non-Kranz) leaf anatomy and are more appropriately placed in sect. Diffusi. C. elegans L., C. rubiginosus Hook. f. (placed by Kükenthal in sect. Turgiduli), and C. trachysanthos Hook. \& Arn. are all very close; they may be better treated as subspecies as done by Eliasson (1965) for C. rubiginosus. C. lacunosus Griseb. and C. oxylepis Nees ex Steud. are more distinctive. C. oxylepis is very similar in glume shape to long-glumed specimens of $C$. rigidellus although differing in other details.

The Section was placed in his subgenus Eucyperus by Kükenthal but it is very close to sect. Pinnati in anatomy and morphology (and flavonoids too probably, although only one species of Glutinosi has been analysed (Harborne \& Williams pers. comm.)). All species of sect. Glutinosi in my restricted sense have A-type anatomy or variants thereof. I sectioned samples of all species; C. elegans was also sectioned by DruytsVoets (1970), who illustrated the culm T.S. (her Figure 5A). Samples of C. lacunosus, C. trachysanthos and C. elegans (Druyts-Voets 1970) showed strict A-anatomy in leaf T.S. However, I found in other samples of C. elegans that the anatomy resembled Aanatomy minus the adaxial layer of small vascular bundles. This was also the situation in C. oxylepis. In small leaves of C. rubiginosus, I found the abaxial layer absent. All these variations correspond to modifications of A-anatomy rather than to B-anatomy since the other characteristics of A-anatomy are still present (adaxial epidermal 
cells of similar size to the abaxial cells and the major vascular bundles forming girders).

The similarity of species of sections Glutinosi and Pinnati was recognised last century (Brown 1810: 215; Mueller 1886: 56). The best summary of the diffences between these two Sections is provided by Blake (1947a) in discussing the affinities of $C$. ixiocarpus:

The affinities of this attractive and distinctive plant are obscure. Mueller suggested a position near the Tropical American C. viscosus Sw. (= C. elegans L.), probably on account of the viscid spikelets, but it differs from this species and its immediate allies (sect. Glutinosi Boeck.) in that it is the spikelets and not the vegetative parts which are viscid, the foliage is less evidently septate-nodulose, the spikelets are not densely capitate, the glumes are more distant, thinner, not bisulcate and have few nerves, the anthers are not crested, and the style is not thickened at the base...' He continued '...The nearest affinity I can suggest [for C. ixiocarpus] is C. zollingeri Steud. [ $=$ C. tenuiculmis Boeck. of section Subquadrangulares of subgenus Eucyperus].'

Sect. Subquadrangulares Kük. (= sect. Subimbricati C.B. Clarke by priority). As suggested by Blake (1947a), this Section in subgenus Eucyperus of Kükenthal's treatment does show some gross resemblance to C. ixiocarpus and to sect. Laxiglumi (see below). However, there are many differences. The Section includes twelve species, mostly in Africa but some, such as C. sphacelatus Rottb. and C. tenuiculmis Boeck., in other tropical regions. Its characteristics are: B-type anatomy (C. sphacelatus examined by Metcalfe (1971); four other species examined by me), spikelets in clearly spicate partial inflorescences, dispersal units the individual flowers, glumes generally broad-elliptic and broadly obtuse. Mature spikelets tend to have a characteristic 'thickened' appearance because of the broad nuts.

Sect. Laxiglumi (C.B. Clarke) Kük. This Section (= sect. Pseudomariscus C.B. Clarke by priority) in subgenus Mariscus of Kükenthal's treatment includes about 28 species from North, Central and South America, with one African species (C. turrillii Kük.). The other African species that Kükenthal included in it (C. baoulensis (Chevalier) Kük.) belongs, in my opinion, in sect. Subquadrangulares of subgenus Eucyperus (see above). I have not seen material of the Himalayan species $C$. sikkimensis Kük., included in sect. Laxiglumi by Kükenthal, but it is phytogeographically unlikely that the species belongs in this Section.

The species of this Section are morphologically similar; Marcks (1974) made a detailed study of the few species of this Section occurring in Wisconsin. The group is characterised by B-type anatomy ( 13 species sectioned by me), spikelets in spicate or subdigitate partial inflorescences, inflorescences small and often reduced to a few more or less capitate clusters, rachilla not or narrowly winged, glumes often relatively very broad, and dispersal units individual flowers as often as whole spikelets. Generally the species are slender perennials with slender surculi or rhizomes, their culms may be slenderly bulbous-based, and their leaves are not septate-nodulose.

Sect. Thunbergiani (C.B. Clarke) Kük. Placed in subgenus Mariscus in Kükenthal's treatment. In it, he put 24 species, mainly from subtropical regions, including C. gunnii, C. cunninghamii, C. aridicola and C. xerophilus (the latter two with the comment 'Nicht gesehen'). The Section as constituted by Kükenthal is anatomically and morphologically mixed. I would include only the species with A-anatomy in this Section (excluding, of course, those species mentioned above, which belong to sect. Pinnati). However, relationships with species in sections Phleoidei and Strigosi need to be considered before proposing a formal re-organisation.

The species of sect. Thunbergiani with A-anatomy (e.g. C. compactus Retz., C. lucidus R. Br., C. ustulatus A. Rich.) differ from those of sect. Pinnati in having long-spicate 
partial inflorescences, and spikelets with broadly winged rachillas (to $5 \mathrm{~mm}$ wide). The dispersal unit is generally the whole spikelet. The plants are mostly very robust, and the leaves are very strongly septate-nodulose, with stout prickles on the margins.

Sect. Turgiduli (C.B. Clarke) Kük. (= sect. Pennati Kunth on priority). This section in subgenus Mariscus in Kükenthal's treatment includes about eleven species from all parts of the tropics (in Australia: C. javanicus Houtt., C. decompositus (R. Br.) F. Muell., C. tetracarpus Boeck. and C. conicus (R. Br.) Boeck.). Kükenthal also included C. rubiginosus (which belongs to sect. Glutinosi), C. holoschoenus (sect. Pinnati) and C. ochroleucus (= C. fulvus). Removing those species, the residual sect. Turgiduli includes species with both A-type anatomy (C. conicus, C. decompositus, C. laeteflorens (C.B. Clarke) Kük., C. javanicus (anatomy illustrated by Govindarajalu 1974) and C. ligularis L. (Metcalfe (1971) as M. rufus)) and B-type anatomy (C. andersonii Boeck., C. hillebrandii Boeck., C. mutisii (H.B.K.) Griseb. and C. seemanianus Boeck.). Despite this, the residual Section seems morphologically fairly homogeneous. It is characterised by $2-$ 3-flowered spikelets in long-spicate partial inflorescences, rachilla often broadly winged, and the dispersal unit always whole spikelets. In these features, it is much closer to what has been called typical Mariscus than the above-mentioned Sections.

\section{Formal taxonomy}

\section{Cyperus section Pinnati}

Cyperus section Pinnati Kük. (1936: 451); Blake (1940: 42), as 'Pinnatae'. Lectotype (Kern 1974): C. angustatus R. Br.

Cyperus section Glomerati C.B. Clarke (1884: 142), p.p. min.

Cyperus section Multiflori C.B. Clarke (1908: 103), as 'Multiflorae', p.p. min.

Cyperus section Ixiocarpi Blake (1947a: 37). Holotype: C. ixiocarpus F. Muell.

[Fulvi Bentham (1878: 255); under Cyerus, no formal status given]

[Lucidi Bentham (1878: 256), p.p.; under Cyperus, no formal status given]

Erect herbaceous annuals or perennials, tufted or occasionally rhizomatous, occasionally viscid. Leaves \pm grasslike, often septate-nodulose, with Mariscus A-type Kranz anatomy. Inflorescence commonly compound; basal inflorescence (involucral) bracts leaf-like, of varying lengths, 1-8 longer than the inflorescence. Spikelets arranged in subdigitate or shortly spicate clusters at the apex of ultimate inflorescence branches, with flowers arranged distichously along the often hyaline-winged rachilla; on senescence, spikelet falling as a unit, or rachilla persistent after glumes have fallen individually, or occasionally units of ultimate branch plus spikelets falling. Stamens 3. Style 3-fid. Nut trigonous or occasionally triquetrous.

Thirty-two species, widespread in Australia with a few species extending to New Guinea and introduced in New Zealand and Europe. The conservation status of these species is satisfactory except for the most geographically restricted species, $\mathrm{C}$. secubans. This is only known from the Nandewar Range (but within Mt Kaputar National Park), and falls into category 2RC in the classification of Leigh et al. (1984).

The species are outbreeding so far as known; flowers are protogynous. Specimens are often found with half-mature nuts as well as pre-anthetic anthers in the same flower. C. cunninghamii subsp. uniflorus might be expected to be chasmogamous with its tightly rolled fertile glume completely enclosing the upper part of the spikelet but at least some specimens (e.g. Hartley 14786, Wilson 4964) have the stamens and/or stigmas exserted from the apex of the glume. Wind is thought to be the pollinating agent (as in most members of the Cyperaceae). 


\section{Keys to species}

Practical keys for identifying sedges are notoriously difficult to produce because of the microscopic nature of most of the distinctive characters of these plants. Such keys are generally understood to be useful only in identifying complete, well-grown specimens. In section Pinnati, the variation is such that a conventional dichotomous key is both very lengthy and inconclusive for some specimens. For these reasons, a multientry key is presented as well. The main advantage of such a key is that one can use whatever characters are available on the specimen, in whatever order one wishes; this is particularly valuable in trying to identify incomplete specimens. Both keys are based on specimens more or less typical for the species, i.e. rare conditions or extreme measurements are generally not covered.

\section{Multi-entry key}

Characters are defined and discussed on pp. 363-391. If characters have only two states, only the less common state is detailed here (the more common state is given in parentheses). All character states are detailed where there are more than two. The numbers refer to the species (as given in the taxonomic section) and letters to their subspecies. Letters are only listed if the subspecies vary in that character. Bold italicised species numbers indicate that those species display only one state of that character, species numbers in plain type indicate species showing more than one state of that character. A species number in parentheses indicates that this state is much less common than the other(s) under which this species is listed.

To use this key, choose one character, check the state found in the specimen and then list all the taxa (numbers and letters) in which that state occurs. Repeat for another character, compare that list with the previous list, and delete any numbers not in common. Parentheses should be noted too: if the taxon number is in parentheses (i.e. uncommon) for several characters, then the specimen is less likely to belong to that taxon than to others listed without parentheses. Continue thus until left with a single number (species) or, given the variation within species in this Section, with several numbers. In either case, the specimen should be compared with the relevant description(s) and illustrations to confirm the identification. Immature or stunted specimens may not key out.

The most reliable (least variable) characters are those of the glumes, nuts, rachilla and leaf marginal prickles. It is advisable to start with these characters. If a distinctive character state is present (such as bulbous culm-bases, scabrous glume midrib, or papillate or flabellate leaf marginal prickles) then that will shorten the search.

A listing of species according to the broad regions in which they are known to occur will enable those users who are sure of the geographical provenance of their specimen (or who wish to produce regional keys) to further restrict their search.

1. Annual or short-lived perennial (vs. perennial): 72627283132

2. Shortly but distinctly rhizomatous (vs. tufted, often forming big tussocks by surculi): 1223

3. Bulbous culm-base (vs. non-bulbous): 691011 (24) (29)

4. Viscid spikelets and/or vegetative parts (vs. non-viscid): 1258131422252729 30

5. Plant height (culm plus inflorescence length)

a. $<55 \mathrm{~cm}: 1$ (2) 3 4abc 5789101112131517 18a 1922232425262728293031 
b. $55-100 \mathrm{~cm}$ : 12 4a $67891012131415161718 \mathrm{ab} 19202122232428$ (29) 30

c. $>100 \mathrm{~cm}$ : $141618 \mathrm{~b} 212224$

6. Culm diameter (halfway along culm)

a. <1.3 mm: 1ac 34 abc 567891011122023242526272829303132

b. $1.3-2.4 \mathrm{~mm}$ : 1abc 234 ab 67891011121415161718202122232426 (27) 28

29303132

c. >2.4 mm: (1a) 2 4a 711 (12) 1314151618192021222324 (29)

7. Culms scabrous, at least above (vs. smooth throughout their length): 12 4ab 678 11122122242527282930

8. Leaf shape in cross-section (halfway along lamina)

a. Canaliculate: 1234 abc $56891011121314151618 a 192021242527$

b. Flattened: 12 4ab $67912141718 \mathrm{ab} 19212324262829303132$

c. Carinate: 79141517 (19) 2021222324272829303132

9. Leaf midrib obvious on lower surface (vs. not obvious): 12 (3) 4ab 679111415 $1718 a b 19202122232426272829303132$

10. Leaves and bracts strongly curly (vs. straight or only slightly curved): 1c $4 b c 525$ 27 (28) (29)

11. Leaf width (halfway along lamina)

a. <1.7 mm: 1ac 34 abc 589101112202425272931

b. $1.7-4.5 \mathrm{~mm}$ : $1 \mathrm{a} b \mathrm{c} 234 \mathrm{ab} 6789101112131415161718192021 a 22232426$ 272829303132

c. $>4.5 \mathrm{~mm}$ : (1a) 2 4a 7 (9) (10) $1316181921 b 222829$

12. Leaf lamina septate-nodulose (vs. not septate-nodulose): 12 4a 78910111314 15161718192021222324262829303132

13. Leaf sheaths obviously septate-nodulose (vs. not septate-nodulose): 4a 671516 1718192021222324262830

14. Leaf sheaths smooth and shining (vs. striate and dull): $123567811161718 b$ 1920212231

15. Leaf sheath colour

a. Stramineous to yellow: Iab $234 \mathrm{a} 7812131417192024262930$

b. Pink to pale orange-brown: 1abc 234 abc 5791011151618 (19) 2125272831 32

c. Red-brown to black: 56812131415161718202122232426272932

16. Leaf margins (in uppermost third to quarter of lamina)

(i) Teeth density

a. Dense (<0.05-0.5 mm apart, \pm regularly spaced): 1abc $2346791415181921 \mathrm{ab}$ 2223242628293032

b. Sparse (0.6-1.5 mm apart, irregularly or regularly spaced): 1abc 256789101112 131415161718192021 a 2223242526272829303132

c. Very sparse (>1.5 mm apart, \pm irregularly spaced): 1ac 2510111316202729

(ii) Teeth irregularly spaced (vs. regular): 1ac $27910111213151718 a 20212324$ 2728293132

(iii) Teeth length

a. Very short (<0.05 mm long): 34514 
b. Short $(0.05-0.10 \mathrm{~mm}$ long): all species and subspecies.

c. Long (>0.10 mm long): $11218 a 21 b 22242627282930$

(iv) Teeth shape

a. Aculeate: $12456789101112131415161718 a b 19202122232426282930$ 3132

b. Papillate: $2351011141518 b$ (22) 2527 (28) 3132

(v) Teeth direction (relative to apex)

a. Antrorse: $123456789101112131415161718 a b 192021222324262829$ 30 (32)

b. Erect: 23591113141518 b 20 (22) 23252728293132

c. Retrorse: 21028

d. Flabellate: 101123252932

\section{Inflorescence: order of branching}

a. Simple: 1a 34 bc 91011121517 21a (22) 2324252627282931 (32)

b. Small-compound: 1ab 3 4ac 5891011121517 18a 20 21ab (22) 232426293032

c. Compound: labc 2 4a $5678131415161718 \mathrm{ab} 192021 \mathrm{ab} 222332$

d. Decompound: 2 4a 57 (13) 14192022

18. Primary inflorescence branches

(i) Number

a. More than 11 (vs. no more than 11): 1ac $24 a$ (c) $56713141518 b 1920$ 21b (23) 2426

(ii) Length

a. >10 cm (vs. no more than $10 \mathrm{~cm}$ ): (1a) 23 4a 7 (12) $1314151618 \mathrm{~b} 1920212223$ 26

19. Number of leafy inflorescence bracts exceeding inflorescence

a. 0-1: 4b 568101214 (15) (16) (18a) 20 (23) 25 (26) 27 (28) (29) 31

b. 2: 1abc 2 (3) 4bc 568910111213141516 (17) 18ab 192021222324252627 2829303132

c. 3-4: 1abc $234 \mathrm{abc} 7910111314151617$ 18ab 192122 (23) 2426272829 (30) 31 32

d. 5 or more: (1a) $24 a 79$ (11) 17 (19) (29) (30)

20. Spikelet clusters

(i) Shape

a. Ovoid: $1 \boldsymbol{b} 9101130$

b. Globose: 1ac78 814161719 21a 22232526272829303132

c. Hemispherical (more or less so - often with very few spikelets): 1c 23456789 $101112131415161718192021 \mathrm{ab} 222324262729303132$

(ii) Spikelets arranged spicately in the clusters (vs. subdigitately arranged): 1a 611 $18 \mathrm{~b} 21 \mathrm{~b} 22242930$

(iii) Diameter

a. <1.2 cm: 1abc $24 a(b) c 567891011$ (12) 14151617 (19) (20) 21a(b) (22) (23) 24 25 (26) (27) 32

b. 1.2-2.5 cm: 1ab 23 4ab 56 (7) 910111213141517 18(a)b 192021 ab 22232425 26272829303132

c. $>2.5 \mathrm{~cm}: 23$ 4b $6121318 \mathrm{ab} 1920$ 21(a)b 22 (23) 262728293031

21. Spikelet

(i) Shape in cross-section

a. Terete (vs. laterally compressed): $1 \mathrm{ac}$ 


\section{(ii) Length}

a. <6 mm: 1ac 4ac 56789101114151617 (18a) 192224273032

b. 6-20 mm: 1ab 23 4abc 567 (8) (9) (10) (11) 1213141517 18ab 192021222324 2526272829303132

c. $>20 \mathrm{~mm}: 3$ 4b 1213 18ab (19) (20) (21) (22) (23) 26 (27) (29) 31

(iii) Width (from glume apex to glume apex)

a. $<1.2 \mathrm{~mm}$ : 1ac $4 \mathrm{a} 521 \mathrm{~b}$

b. 1.2-2.5 mm: 1ab $234 \mathrm{abc} 56789101112141516$ (17) 18ab $192021 a \mathrm{~b} 22$ (23) 24

(25) 26 (27) 2930 (31) 32

c. $>2.5 \mathrm{~mm}$ : $1 \mathrm{~b} 4 \mathrm{~b} 89111315161718 \mathrm{~b} 222324252728293132$

(iv) Number of fertile flowers per spikelet

a. <6: 1abc 2 (3) 4abc 567891011 (14) (15) 1617 (21b) 242530

b. 6-20: 1ab 23 4abc 56791011121314151617181920 21ab 222324252627 2829303132

c. >20: (2) 3 4ab 121314 (15) 18 (19) (20) 21ab (22) (23) (26) (27) (29) (30) 31

\section{Rachilla}

(i) Wing broad, i.e. 0.1-0.25 mm wide (vs. absent or narrow): 14 ac 5 (6) 7891011

1213 18ab 21a 2223262728293031

(ii) Thick in side view, i.e. at least $1.0 \mathrm{~mm}$ thick (vs. thin): $34 a b c 5$ (6) 9 (11) 14 (15) (32)

(iii) Glume spacing (i.e. distance between adjacent glume bases on same face of rachilla)

a. <1.4 mm: (2) 4567 (8) 1011121415161718 b 1920 21a 2223 (24) 2527282931 32

b. 1.4-2.1 mm: (1a) 23456 (7) 8910 (11) 12 (14) 18ab 21ab 2223242526272829 3031 (32)

c. $>2.1 \mathrm{~mm}: 1 \mathrm{ab} 13$ 18a $21 \mathrm{a} 2427$

\section{Glume}

(i) Length of mucro

a. $<0.25 \mathrm{~mm}$ : 1abc $234 a \mathrm{bc} 56789101112131415161718 a b 19202122232425$

2627293032

b. $0.25-0.45 \mathrm{~mm}$ : 1a 34 bc $7891318 \mathrm{~b} 2223242627282931$

c. $>0.45 \mathrm{~mm}$ : (7) 89131823 (26) 28 (29) 31

(ii) Shape of mucro

a. Excurved: $1 \mathrm{a} 4 \mathrm{~b} 78918 \mathrm{a} 202223272831$

b. Straight: 1abc $234 a b c 5679101112131415161718 \mathrm{ab} 192021$ (22) 232425 2627 (28) 293032

c. Incurved: 910

(iii) Overall length of glume (including mucro)

a. $<2.2 \mathrm{~mm}$ : 4 abc 56789101112141516 (18b) 1920 21ab (22) 27293032

b. 2.2-3.0 mm: 123 4b 8910111213 (14) $151718 \mathrm{ab} 192021 \mathrm{ab} 22232425$ (26) 27

2829 (30) (31) 32

c. $>3.0 \mathrm{~mm}: 14 \mathrm{~b} 18 \mathrm{ab} 21 \mathrm{a} 22232426272831$

(iv) Width of glume in side view (i.e. from midrib to lateral margin)

a. <0.7 mm wide: 1ac $234 a b c 5679101112131415161718192021 a b 242829$ 303132

b. $0.7-0.9$ mm wide: $1 \mathrm{a} b$ (4b) 6789101113141517181921 a 22232425262728 29303132

c. $>0.9$ mm wide: 1a 8911222324252728 (29) 32

(v) Shape of glume (as seen if flattened out)

a. Obovate to elliptic (i.e. broadest in uppermost third to half): 1234 ac 56781011 
1213141516181920212223242526272829303132

b. Ovate (i.e. broadest in lowermost third): 3 4abc 6789111213141516171819 202324252627283132

(vi) Midrib scabrous (vs. smooth): (1) 7 (8) 16

(vii) Glume margins inrolled and clasping nut (vs. not inrolled and thereby not clasping nut, unless viscid): 1ac $235151718 \mathrm{ab} 192021222324252627282930$ 31

\section{(viii) Colour of glume}

a. Stramineous to dark golden-brown: 1234568910111213141516171819 (20)

21(a)b 2224262829303132

b. Stramineous to golden with red-brown blotches: 62729

c. Red-brown to dark red-brown: 2345678910111216 (18) (19) 20 21ab 222324 25273132

\section{Anther}

(i) Length (excluding appendage)

a. <1.2 mm: 1abc 23456789101213141516171819202122262728293031 32

b. $1.2-1.5 \mathrm{~mm}$ : 1abc (2) 1113 (17) 18212223242526 (27) (29)

c. $>1.5 \mathrm{~mm}$ : 1b 1122232425

(ii) Length of apical appendage

a. <0.15 mm: 1a 2 (4c) (5) 810111213141516171819202122232425262728 293031

b. $0.15-0.35 \mathrm{~mm}$ : 1abc 23 4abc 5678910111416 (24) 32

c. $>0.35 \mathrm{~mm}$ : 1c 3 4abc 6832

25. Nut

(i) Length

a. <1.6 mm: (2) 345781011 (12) $1416192021 \mathrm{a} 27293032$

b. 1.6-2.3 mm: 1abc $2345689101112131415161718 a b 192021 \mathrm{ab} 22232425$

262728293132

c. $>2.3 \mathrm{~mm}$ : $1 \mathrm{ab} 18 \mathrm{~b}$ (23) 262731

(ii) Diameter

a. <0.6 mm: 1ac 23 4abc 5679101112151617181920 21ab 222427303132

b. $0.6-0.8 \mathrm{~mm}$ : 1ab 4a 67891011121415 (16) 21a 2223242526272829 (30) (32)

c. $>0.8 \mathrm{~mm}: 8913(29)$

(iii) Shape (in outline)

a. Obovate: 4a 5678910111213141518 b 192223252627293032

b. Elliptic or linear: 1234 abc $5691012131415161718 a b 1920212223242526$

2728293132

c. Ovate: $1234 \mathrm{a} 17$

(iv) Faces

a. Concave: 4a 678911131416172728

b. Flat: 1abc 234 abc 67910111214151617181920212223242526272829

303132

c. Convex: 1ab 515212426272930

(v) Surface texture

a. Tuberculate (i.e. with small widely spaced elevations): 1abc $234 a c 567891013$ 2022272831

b. Colliculate (with broad, rounded elevations completely covering the surface): $34 \mathrm{~b}$ $56101314151618 a b 19212324252627293032$

c. Smooth and reticulate-areolate: 1a 2 4bc $11121415161718(a) b 192021232425$ 26 (29) 303132

d. Foveate (pitted): 1a 4b 1419202426303132 
(vi) Surface more or less evenly shining (vs. glistening or dull): $4 a b c 589101112$ 1314151617182123242526293032

\section{(vii) Colour}

a. Pale yellow-brown to dark golden-brown: 10111215161718192021232425 262729

b. Pale to dark red-brown: 12345691011121314151621222425303132

c. Grey to black: 1345 (6) 78913142831

(viii) Nut falling separately from glume (vs. falling clasped by glume): 1b 34567 8910111216 (23) 27283032

\section{Regions of occurrence}

a. Queensland: 1ab 4ac 671011121315161718192021 ab 22262728293031

b. New South Wales: 18a 19 21a 22232527282931

c. Victoria: 21 a 2327

d. Tasmania: $21 \mathrm{a}$

e. South Australia: 19 21a 2223242731

f. Northern Territory: $12456789101112131415161718 b 2024273132$

g. Western Australia: $12345681011131415161718 b 22242732$

h. New Guinea: 121629

i. New Zealand: 21a

\section{Bracketed dichotomous key}

The number in brackets after certain leads (e.g. after lead 5) refers back to the previous lead in that path.

1 Culm bases bulbous 2

1 Culm bases not bulbous (or rarely somewhat bulbous, in young plants) $\quad \ldots . .6$

2 Anthers $0.4-1.0 \mathrm{~mm}$ long 3

2 Anthers $1.2-2.3 \mathrm{~mm}$ long

3 Inflorescence compound; spikelets few in loose clusters 6. C. sexflorus

3 Inflorescence simple or small-compound; spikelets numerous in dense clusters

4 Rachilla thickened, broadly winged, wings $0.1-0.2 \mathrm{~mm}$ wide; glume spacing $1.5-$ $2.1 \mathrm{~mm}$; glumes broad-ovate with mucro $0.2-0.5 \mathrm{~mm}$ long; nut very dark red-brown to black

9. C. sporobolus

4 Rachilla not thickened, usually narrowly winged, wings to $0.1 \mathrm{~mm}$ wide; glume spacing $0.7-1.5 \mathrm{~mm}$; glumes elliptic with mucro $<0.1-0.2 \mathrm{~mm}$ long; nut pale yellow-brown to pale red-brown

10. C. orgadophilus

5 Nut obovate; glume margins not inrolled

11. C. blakeanus

5 Nut very narrow-elliptic; glume margins inrolled and clasping the nut

24. C. centralis

6 (1) Spikelets with 1 fertile flower, more or less terete

1. C. cunninghamii

6 Spikelets with 2-50 fertile flowers, more or less laterally compressed $\quad$............ 7

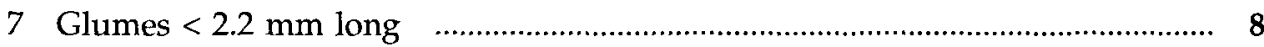

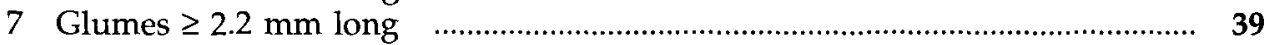

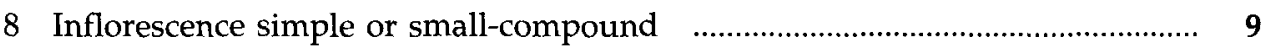

9 Inflorescence compound to decompound …................................................... 25

9 Plant with long slender rhizome

12. C. angustatus

9 Plants tufted or forming tussocks by short surculi 


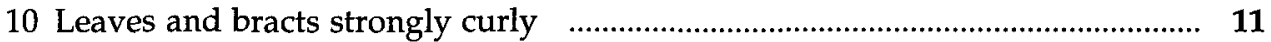

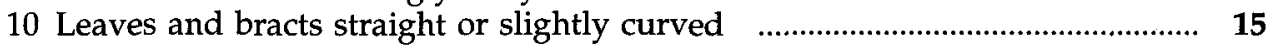

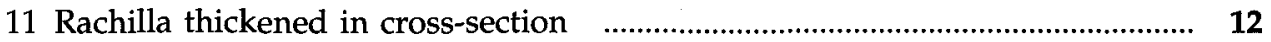

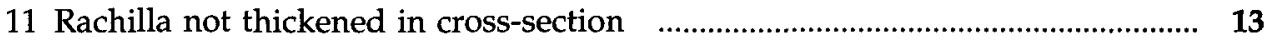

12 Leaf marginal prickles dense, antrorsely aculeate ............. 4. C. microcephalus

12 Leaf marginal prickles sparse to very sparse, mixed: antrorse to erect, aculeate to papillate

5. C. crispulus

13 Mature nut very dark red-brown to black

5. C. crispulus

13 Mature nut pale brown

14 Spikelets in subdigitate clusters; leaf sheaths pinkish to purplish red

14 Spikelets in shortly spicate clusters; leaf sheaths yellowish with red-brown blotches

29. C. fulvus

15 (10) Rachilla thickened in cross-section

4. C. microcephalus

15 Rachilla not thickened in cross-section

16 Glume margins more or less strongly inrolled and clasping nut so that nut and glume fall together

16 Glume margins not or only slightly inrolled so that nut and glume usually fall separately

17 Nut surface tuberculate or foveate

17 Nut surface colliculate or smooth and reticulate-areolate

18 Anthers $0.3-0.7 \mathrm{~mm}$ long; leaf marginal prickles short and very sparsely and irregularly spaced

20. C. fucosus

18 Anthers 1.1-1.8 mm long; leaf marginal prickles long and usually densely and regularly spaced

22. C. alterniflorus

19 Leaf sheaths pinkish to dark red-purple; glume spacing $0.7-1.2 \mathrm{~mm}$

15. C. carinatus

19 Leaf sheaths stramineous (with or without red-brown blotches) to orange- or grey-brown; glume spacing 1.2-2.2 mm

20 Nut very narrow-elliptic to narrow-elliptic

21. C. gunnii

20 Nut obovate to narrow-obovate or broad-elliptic 21

21 Nut $1.5-2.0 \mathrm{~mm}$ long, $0.6-0.9 \mathrm{~mm}$ diam.; leaf marginal prickles irregularly spaced, mixed flabellate to erect or antrorsely aculeate; spikelets $2-3.5 \mathrm{~mm}$ wide in side view; glumes $0.6-1 \mathrm{~mm}$ wide in side view

29. C. fulvus

21 Nut $1.3-1.5 \mathrm{~mm}$ long, $0.5-0.6 \mathrm{~mm}$ diam.; leaf marginal prickles regularly spaced, strongly antrorsely aculeate; spikelets $1.5-2 \mathrm{~mm}$ wide in side view; glumes $0.5-0.7$ $\mathrm{mm}$ wide in side view

30. C. perangustus

22 (16) Anthers 1.2-2.0 $\mathrm{mm}$ long

11. C. blakeanus

22 Anthers $0.3-1.1 \mathrm{~mm}$ long

23 Glumes broad-elliptic to broad-ovate, with mucro $0.2-0.6 \mathrm{~mm}$ long; nut broadobovate to obovate, black, $0.7-1.3 \mathrm{~mm}$ diam.

8. C. cracens

23 Glumes narrow-ovate to elliptic, with mucro $0.1-0.2 \mathrm{~mm}$ long; nut narrowobovate to narrow-elliptic, red-brown, $0.4-0.6 \mathrm{~mm}$ diam.

24 Culms scabrous; spikelet clusters spicate; leaf marginal prickles long antrorsely aculeate

30. C. perangustus

24 Culms smooth; spikelet clusters subdigitate; leaf marginal prickles short, mixed 
25 (8) Leaves and bracts strongly curly

25 Leaves and bracts straight or only slightly curved

5. C. crispulus

26 Anthers $<1.2 \mathrm{~mm}$ long 26

26 Anthers $1.2-1.8 \mathrm{~mm}$ long 27

27 Mucro excurved (occasionally \pm straight in C. portae-tartari), $0.2-0.6 \mathrm{~mm}$ long; glumes occasionally with antrorse prickles on midrib 28

27 Mucro straight, $\leq 0.2 \mathrm{~mm}$ long; glumes smooth (rarely minutely scabrous in C. holoschoenus)

28 Inflorescence narrow, slender, with 1-2 long involucral bracts; glumes $0.8-1.1 \mathrm{~mm}$ wide in side view; leaves canaliculate in cross-section, midrib not obvious

8. C. cracens

28 Inflorescence about as broad as long, with $3-8$ long bracts; glumes $0.5-0.7 \mathrm{~mm}$ wide in side view; leaves $\mathrm{V}$-shaped, midrib obvious abaxially and scabrous

7. C. portae-tartari

29 Nut tuberculate

4. C. microcephalus

29 Nut smooth and reticulate-areolate or colliculate or foveate 30

30 Nut falling with glume 31

30 Nut falling separately from glume 35

31 Mature spikelets viscid; nut dark red-brown to black

31 Mature spikelets not viscid; nut yellow-brown to pale red-brown

14. C. viscidulus

32 Glumes stramineous or yellowish with broad white-membranous margins

15. C. carinatus

32 Glumes yellow or red with margins of a similar colour and texture or narrowhyaline

33 Glume spacing $0.9-1.3 \mathrm{~mm}$; anthers $0.3-0.7 \mathrm{~mm}$ long 34

33 Glume spacing 1.3-2.2 $\mathrm{mm}$; anthers $0.7-1.5 \mathrm{~mm}$ long 35

34 Glumes bright yellow to dark golden-brown (rarely red-brown), 1.3-2.1 mm long, with acute apex; involucral bracts (2-)3-5; leaf margins with prickles regularly spaced

19. C. dactylotes

34 Glumes dull red-brown or occasionally stramineous, $1.8-2.8 \mathrm{~mm}$ long, with apex retuse to broad-acute; involucral bracts 1-2; leaf margins with prickles irregularly spaced

20. C. fucosus

35 Leaf marginal prickles antrorsely aculeate; leaf sheaths striate but shining 21. C. gunnii

35 Leaf marginal prickles mixed antrorse to erect, aculeate to papillate; leaf sheaths smooth and shining

18. C. betchei

36 (30) Glume spacing $0.5-0.9 \mathrm{~mm}$; spikelets 2-5 mm long, 2-6-flowered; leaf marginal prickles antrorsely aculeate

16. C. holoschoenus

36 Glume spacing 1.0-1.5 mm; spikelets 5-17 mm long, 6-20-flowered; leaf marginal prickles erect to flabellate, aculeate to papillate

32. C. latzii

37 (26) Nut tuberculate, red-brown

22. C. alterniflorus

37 Nut smooth to colliculate, yellow-brown 38

38 Leaf marginal prickles antrorsely aculeate; leaf sheaths striate but shining

21. C. gunnii

38 Leaf marginal prickles mixed antrorse to erect, aculeate to papillate; leaf sheaths smooth and shining

18. C. betchei 


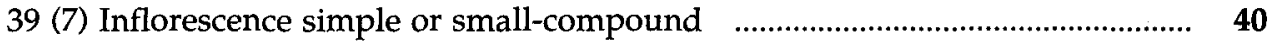

39 Inflorescence compound to decompound ………….................................. 77

40 Plants with long, slender rhizome ..................................................................... 41

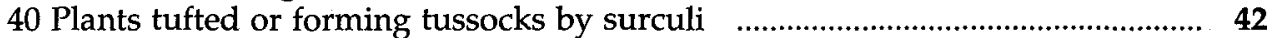

41 Glumes $1.6-2.3 \mathrm{~mm}$ long, c. $0.5 \mathrm{~mm}$ wide in side view …...... 12. C. angustatus

41 Glumes $2.6-4.0 \mathrm{~mm}$ long, $0.8-1.0 \mathrm{~mm}$ wide in side view ... 23. C. lhotskyanus

42 Leaves and bracts strongly curly ..................................................................... 43

42 Leaves and bracts straight or slightly curved ……......................................... 48

43 Rachilla thickened

4. C. microcephalus

43 Rachilla not thickened ................................................................................... 44

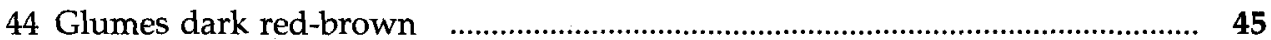

44 Glumes stramineous to golden brown, sometimes with red-brown blotches $\mathbf{4 6}$

45 Anthers 1.3-1.6 mm long; glume mucro $\leq 0.1 \mathrm{~mm}$ long; leaf marginal prickles mixed erect to flabellate, papillate or aculeate, regularly spaced 25 . C. secubans

45 Anthers $0.3-1.2 \mathrm{~mm}$ long; glume mucro $0.1-0.4 \mathrm{~mm}$ long; leaf marginal prickles erect, papillate, irregularly spaced …………........................... 27. C. rigidellus

46 Glumes evenly yellow to golden brown, with mucro $0.3-0.8 \mathrm{~mm}$ long (usually excurved); nut [tuberculate, grey to black …………………......... 28. C. clarus

46 Glumes stramineous to golden brown and with dull red-brown blotches, with straight mucro 0.1-0.3 mm long; nut pale yellow-brown

47 Leaf marginal prickles erect, papillate; spikelets arranged subdigitately in clusters; nut tuberculate or small-colliculate ………………….............. 27. C. rigidellus

47 Leaf marginal prickles either mixed strongly flabellate to erect aculeate or antrorsely aculeate; spikelets arranged spicately in clusters; nut colliculate to smooth and reticulate-areolate

29. C. fulvus

48 (42) Rachilla thickened as seen in side view

3. C. hesperius

48 Rachilla thin

49 Glume margins more or less strongly inrolled and clasping nut so that nut and glume fall together ................................................................................. 50

49 Glume margins not or only slightly inrolled; nut and glume usually falling separately 62

50 Nut red-brown to black, tuberculate (occasionally smooth in C. cunninghamii and C. gilesii)

50 Nut yellow-brown to dark golden-brown (occasionally pale red-brown in C. gunnii and C. centralis), smooth to colliculate or foveate

51 Glume spacing $2.0-4.7 \mathrm{~mm}$

1. C. cunninghamii

51 Glume spacing $1.0-1.9 \mathrm{~mm}$

52 Anthers 1.1-1.8 mm long [nut red-brown, narrow-elliptic to narrow-obovate]

22. C. alterniflorus

52 Anthers $0.3-0.8 \mathrm{~mm}$ long

53 Nut very narrow-elliptic, red-brown to blackish; glumes very narrow-elliptic to narrow-ovate

31. C. gilesii

53 Nut obovate, grey to black; glumes elliptic to ovate

28. C. clarus

54 (50) Leaf margins antrorsely aculeate, more or less regularly spaced ….......... 55

54 Leaf margins mixed aculeate to papillate, antrorse to erect and flabellate, more or less irregularly spaced 
55 Spikelet clusters dense; leaves exceeding or as long as culms; culms $2-4 \mathrm{~mm}$ diam. 21. C. gunnii

55 Spikelet clusters loose; leaves shorter than to as long as culms; culms 1-2.7 mm diam.

56 Anthers 1.3-2.3 mm long; rachilla not or very narrowly winged 24. C. centralis

56 Anthers $0.7-1.4 \mathrm{~mm}$ long; rachilla narrowly to broadly winged 57

57 Tussock-forming perennial

18. C. betchei

57 Tufted annual or short-lived perennial 26. C. isabellinus

58 (54) Anthers 0.3-1.2 mm long

58 Anthers 1.3-2.0 mm long

59 Nut obovate to elliptic, $0.6-1 \mathrm{~mm}$ diam.; glume spacing $1.2-2.0 \mathrm{~mm} \quad 29$. C. fulvus

59 Nut very narrow-elliptic to narrow-obovate, $0.4-0.7 \mathrm{~mm}$ diam.; glume spacing $0.7-$ $1.3 \mathrm{~mm}$

60 Leaf midrib obvious abaxially; glumes stramineous to yellow with broad white membranous margins; spikelet clusters dense

15. C. carinatus

60 Leaf midrib not obvious; glumes dull red-brown or pallid with narrow hyaline margins; spikelet clusters loose

20. C. fucosus

61 (58) Leaves V-shaped in cross-section, with midrib obvious abaxially, marginal prickles mixed antrorse to erect and flabellate, aculeate, irregularly spaced; plants not viscid

23. C. lhotskyanus

61 Leaves canaliculate, with midrib not obvious, marginal prickles erect to flabellate, papillate, regularly spaced; plants often viscid

25. C. secubans

62 (49) Anthers less than $1.2 \mathrm{~mm}$ long

62 Anthers $1.2-2.0 \mathrm{~mm}$ long (rarely anthers $1.1 \mathrm{~mm}$ long in C. cunninghamii subsp. cheradicus and C. alterniflorus)

63 Leaf marginal prickles regularly antrorsely aculeate

63 Leaf marginal prickles mixed, irregularly or regularly spaced

64 Nut 0.8-1.3 mm diam., obovate to broad-obovate, tuberculate, black 8. C. cracens

64 Nut $0.3-0.7 \mathrm{~mm}$ diam., very narrow-elliptic to narrow-ovate, colliculate to smooth, yellow-brown to dark golden-brown (occasionally pale red-brown)

65 Glume spacing $0.7-1.2 \mathrm{~mm}$; spikelets $2.5-3.5 \mathrm{~mm}$ wide in side view; glumes stramineous, long-acute and densely arranged to give a striking chevron effect

65 Glume spacing 1.2-2.3 mm (if $<1.5 \mathrm{~mm}$, then glumes dark red-brown); spikelets 1-2.5 $\mathrm{m}$ wide in side view; glumes broad-acute to obtuse

66 Spikelet clusters dense, with numerous spikelets; leaves longer than to as long as culms; glumes dark red-brown or stramineous

21. C. gunnii

66 Spikelet clusters loose, with no more than 10 spikelets; leaves shorter than to as long as culms; glumes yellowish to dark golden-brown

67 Culms smooth; glume spacing $1.6-2.3 \mathrm{~mm}$; rachilla wings $0.1-0.25 \mathrm{~mm}$ wide; anthers 0.8-1.4 mm long; nut 1.9-2.2 mm long

18. C. betchei

67 Culms scabrous; glume spacing $1.4-1.7 \mathrm{~mm}$; rachilla wings $0.05-0.1 \mathrm{~mm}$ wide; anthers $0.3-0.7 \mathrm{~mm}$ long; nut $1.3-1.5 \mathrm{~mm}$ long

30. C. perangustus

68 (63) Nut obovate, grey to black, $0.6-0.8 \mathrm{~mm}$ diam.; glume mucro $0.3-0.8 \mathrm{~mm}$ long, more or less excurved

28. C. clarus

68 Nut very narrow-elliptic to narrow-ovate, yellow-brown to dark red-brown (occasionally black in $C$. hesperius); glume mucro $\leq 0.3 \mathrm{~mm}$ long, mostly straight 
69 Tall but slender perennial, 65-90 cm high; anther appendage $\leq 0.1 \mathrm{~mm}$ long 69 Short perennial, $30-50 \mathrm{~cm}$ high; anther appendage $0.2-0.5 \mathrm{~mm}$ long 20. C. fucosus

70 Glume spacing $1.5-1.8 \mathrm{~mm}$; rachilla thick in side view; inflorescence clusters $2-5$ $\mathrm{cm}$ diam.; spikelets c. $2 \mathrm{~mm}$ wide in side view

3. C. hesperius

70 Glume spacing $1.0-1.5 \mathrm{~mm}$; rachilla thin; inflorescence clusters $1-2 \mathrm{~cm}$ diam.; spikelets $2-4 \mathrm{~mm}$ wide in side view

32. C. latzii

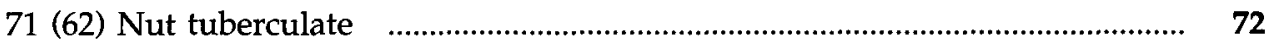

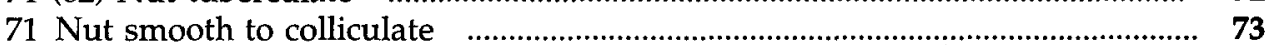

72 Glume spacing $2.2-3.5 \mathrm{~mm}$

72 Glume spacing $1.0-1.9 \mathrm{~mm}$

1. C. cunninghamii

22. C. alterniflorus

73 Leaf marginal prickles more or less regularly antrorsely aculeate 74

73 Leaf marginal prickles mixed aculeate to papillate, antrorse to erect and flabellate, irregularly or regularly spaced

74 Spikelet clusters dense; leaves longer than to as long as culms; glumes dark redbrown or stramineous

21. C. gunnii

74 Spikelet clusters loose; leaves shorter than to as long as culms; glumes yellowish to dark golden-brown

18. C. betchei

75 Leaves V-shaped in cross-section, leaf bases dark purplish red

23. C. Ihotskyanus

75 Leaves canaliculate in cross-section; leaf bases pale brown, occasionally with redbrown blotches

76 Leaf marginal prickles irregularly spaced, aculeate to papillate, antrorse to erect; glumes yellowish with red-brown blotches or evenly red-brown, narrow-ovate with long-acute apex; spikelets mostly 3-5 mm long

11. C. blakeanus

76 Leaf marginal prickles regularly spaced, papillate, erect to flabellate; glumes dark red-brown, obovate to elliptic with retuse to broad-acute apex; spikelets 7-9 mm long

25. C. secubans

77 (39) Nut broad-obovate to obovate (occasionally narrow-elliptic in C. ixiocarpus), black, $0.8-1.3 \mathrm{~mm}$ diam

77 Nut very narrow-elliptic to narrow-obovate, yellow-brown to red-brown (occasionally black in C. cunninghamii but then very narrow-elliptic to narrowovate), $0.3-0.7 \mathrm{~mm}$ diam. (rarely to $1 \mathrm{~mm}$ diam. in C. lhotskyanus)

79

78 Glume spacing $1.3-1.8 \mathrm{~mm}$

8. C. cracens

78 Glume spacing $2.2-2.7 \mathrm{~mm}$

13. C. ixiocarpus

79 Leaf marginal prickles regularly antrorsely aculeate

79 Leaf marginal prickles more or less irregularly mixed

80 Nut pale red-brown to black, tuberculate or occasionally smooth or foveate

80 Nut pale yellow-brown to dark golden-brown, colliculate or smooth

81 Glume spacing $2.0-4.7 \mathrm{~mm}$; glumes stramineous to golden-brown

81 Glume spacing 1.0-1.9 mm; glumes red-brown to golden-brown

1. C. cunninghamii

22. C. alterniflorus

82 Glume spacing 0.7-1.2 mm; glumes stramineous, long-acute and densely arranged to give a striking chevron effect

17. C. oxycarpus

82 Glume spacing $1.2-2.3 \mathrm{~mm}$ (if $<1.5 \mathrm{~mm}$, then glumes dark red-brown); glumes broad-acute to obtuse 
83 Spikelet clusters dense; leaves longer than to as long as culms; glumes dark redbrown or stramineous …................................................................ 21. C. gunnii

83 Spikelet clusters loose; leaves shorter than to as long as culms; glumes yellowish to dark golden-brown

18. C. betchei

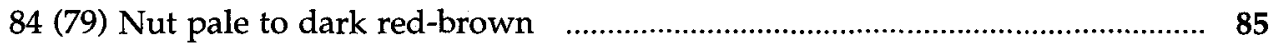

84 Nut pale yellow-brown to dark golden-brown .................................................. 86

85 Tall perennial 50-100 $\mathrm{cm}$ high, culms 2-5 mm diam., leaves 3.5-11 mm wide; glume spacing 1.3-2.1 mm; nut falling with glume ............................ 2. C. astartodes

85 Short annual or perennial 30-50 cm high, culms 1-2 mm diam., leaves $2-4 \mathrm{~mm}$ wide;

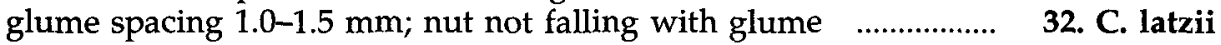

86 Anthers 1.3-1.7 $\mathrm{mm}$ long; slender perennial with long surculi, forming small tufts 23. C. lhotskyanus

86 Anthers $0.4-1.3 \mathrm{~mm}$ long; robust perennials forming large tussocks 87

87 Glumes with broad white-membranous margins

15. C. carinatus

87 Glumes with margins of similar texture to rest of glume or narrow-hyaline $\quad \mathbf{8 8}$

88 Glume spacing $1.3-2.0 \mathrm{~mm}$; anthers $0.7-1.3 \mathrm{~mm}$ long; leaf midrib usually obvious abaxially

18. C. betchei

88 Glume spacing $0.9-1.3 \mathrm{~mm}$; anthers $0.3-0.7 \mathrm{~mm}$ long; leaf midrib usually not obvious

89 Glumes bright yellow to dark golden-brown (rarely red-brown), 1.3-2.1 mm long, with acute apex; involucral bracts (2-)3-5; leaf margins with prickles regularly spaced

19. C. dactylotes

89 Glumes dull red-brown or occasionally stramineous, $1.8-2.8 \mathrm{~mm}$ long, with apex retuse to broad-acute; involucral bracts 1-2; leaf margins with prickles irregularly spaced

20. C. fucosus

\section{Description of species}

\section{Cyperus cunninghamii (C.B. Clarke) C. Gardner Gardner (1930: 12)}

More or less slender perennial, tufted, $30-70(-100) \mathrm{cm}$ high, often viscid towards base of plant and spikelets. Culms trigonous to terete, smooth or scabrous, $1-2(-3.5) \mathrm{mm}$ diam. Leaves occasionally thickened, canaliculate or occasionally flat in big specimens, septate-nodulose in big specimens, shorter than to exceeding culms, to $3(-8) \mathrm{mm}$ wide, pale to mid-yellow green, somewhat shining; midrib mostly not obvious abaxially except near apex but the abaxial surface of the leaf may be scabrous in big specimens; marginal prickles dense to very sparse, regularly or irregularly spaced (0.2-2.0 mm apart), long to short, $0.05-0.25 \mathrm{~mm}$ long, antrorse, aculeate; leaf sheaths not septate-nodulose, \pm shining, papery textured, stramineous to pinkish to orangebrown, with wide white-membranous margins. Inflorescence simple to compound, 215 primary branches 3-18 cm long; bracts erect or spreading, 2-3(-5) much exceeding inflorescence. Spikelets mostly numerous (except in subsp. uniflorus) in loose to dense, spicate to subdigitate, ovoid to globose clusters of $0.5-2 \mathrm{~cm}$ diam.; spikelets terete or laterally compressed, oblong to narrow-ovate, $2.5-12 \mathrm{~mm}$ long, $0.3-2(-3) \mathrm{mm}$ wide in side view, 1-8-flowered, often viscid; rachilla not thickened, broadly winged, with the wings $0.10-0.25 \mathrm{~mm}$ wide and clasping the nut; glume spacing $2.0-4.7 \mathrm{~mm}$; spikelet usually falling as a unit, or units of ultimate branch plus spikelets falling, or rarely rachilla persistent and glumes falling individually. Glumes narrow-elliptic to narrow-obovate, \pm excurved, retuse to acute with straight or excurved mucro $0.1-0.4$ 
$\mathrm{mm}$ long, pale yellow to dark golden-brown with a narrow green midrib (occasionally scabrous), $2.5-4.5 \mathrm{~mm}$ long, $0.5-1.0 \mathrm{~mm}$ wide, sides 2-6-nerved, margins inrolled (strongly so in terete spikelets with widely spaced glumes) or not inrolled (subsp. cheradicus), margins membranous (mostly broad-hyaline but may not be obvious due to inrolling and viscidity). Anthers (0.5-) $1.0-2.0 \mathrm{~mm}$ long excluding appendage $0.1-0.5$ $\mathrm{mm}$ long. Nut trigonous or triquetrous, very narrow-elliptic to linear or narrow-ovate with acute apex, faces flat to slightly convex, red-brown to black, tuberculate to foveate, glistening, $1.7-3.0 \mathrm{~mm}$ long, $2 / 3$ as long as to equalling glume, $0.3-0.7 \mathrm{~mm}$ diam., falling with the glume or falling separately from it. Figure $9 a-i$.
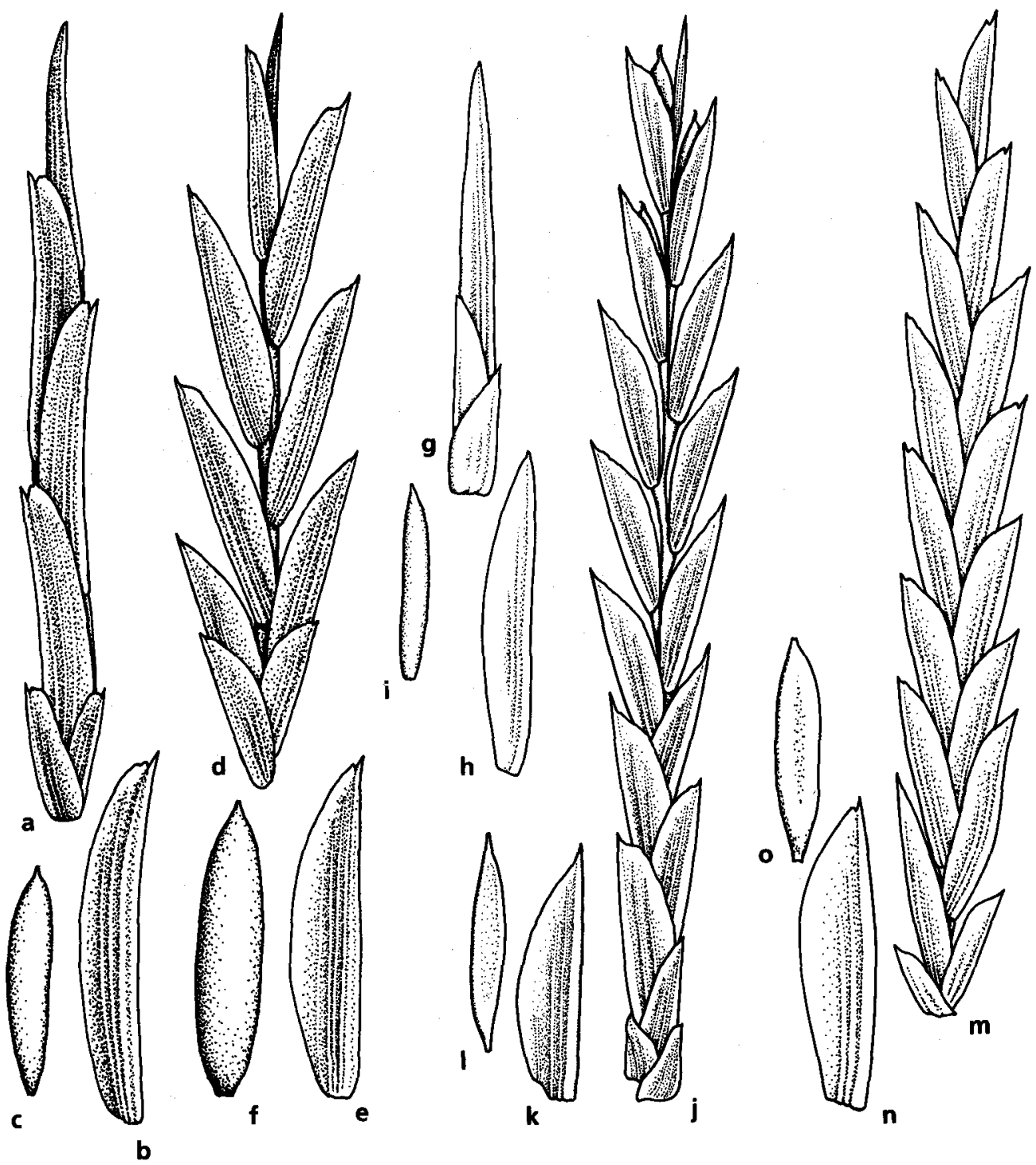

Figure 9. Spikelet details. Cyperus cunninghamii subsp. cunninghamii: $\mathbf{a}$, spikelet; $\mathbf{b}$, glume; $\mathbf{c}$, nut. C. cunninghamii subsp. cheradicus: $\mathbf{d}$, spikelet; $\mathbf{e}$, glume; $\mathbf{f}$, nut. $C$. cunninghamii subsp. uniflorus: $\mathbf{g}$, spikelet; $\mathbf{h}$, glume; $\mathbf{i}$, nut. C. astartodes: $\mathbf{j}$, spikelet; $\mathbf{k}$, glume; $\mathbf{1}$, nut. C. hesperius: $\mathbf{m}$, spikelet; $\mathbf{n}$, glume; o, nut. a-c from Latz 2014; d-f Blake 8754; g-i Wilson 5302; j-1 Latz 7302; $\mathbf{m}-\mathrm{o}$ Beauglehole 48826. a, d, g, j, m X 11; b, c, e, f, h, i, k, l, n, o X 14. 
Distribution: Central and northern Australia, extending to the Pilbara and Mt Isa regions of Western Australia and Queensland respectively. Figure 10a-c.

HABITAT: Rocky areas, on ledges, around base of boulders, or in gullies or creeks.

C. cunninghamii differs from all other species in this group in its spikelets, which are often terete (at least when immature, except in subsp. cheradicus) and are few-flowered but still relatively long because of the large glume spacing. It differs from C. astartodes, C. microcephalus and C. hesperius in having the rachilla broadly winged. The marginal prickles on the leaves are also distinctive, being long, sparse and antrorsely aculeate. See also notes under $C$. astartodes and $C$. centralis.

As in C. microcephalus (q.v.), there is considerable variation within this species, which it has not been possible to explore fully. Tentatively, three subspecies are recognised. Further study may show them to be more appropriately treated as species.

The inflorescence of subspecies uniflorus has a distinctive appearance, with clusters of usually few spikelets, the spikelets being terete and one-flowered, with the glume of the fertile flower completely enclosing the rachilla and nut at maturity. However, one-flowered spikelets are also found in subsp. cunninghamii, and other differences are quantitative rather than qualitative, leaving the enveloping fertile glume as the only consistent morphological difference between these two taxa. Distributions overlap in the extreme north-east of the Kimberley and in the northern ranges of the Northern

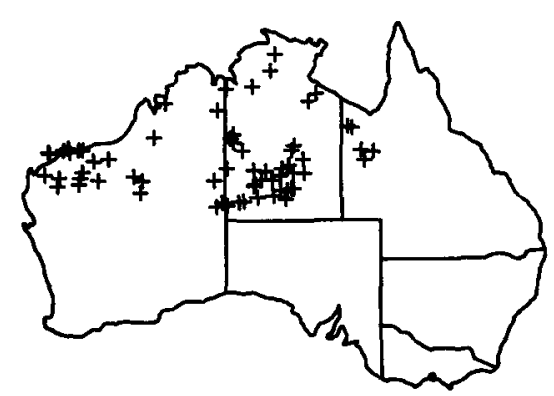

a

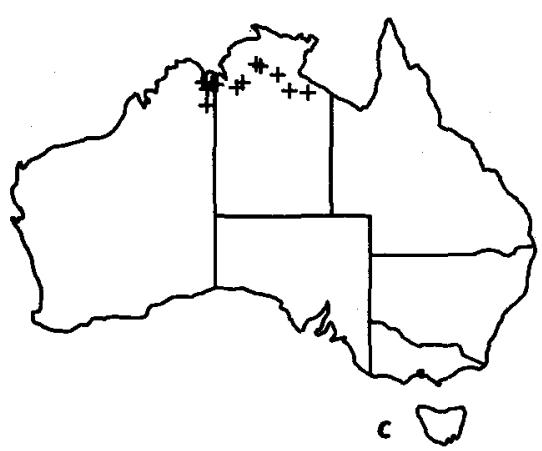

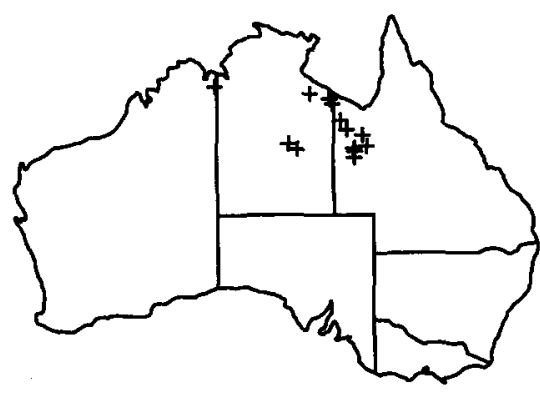

b $\square$

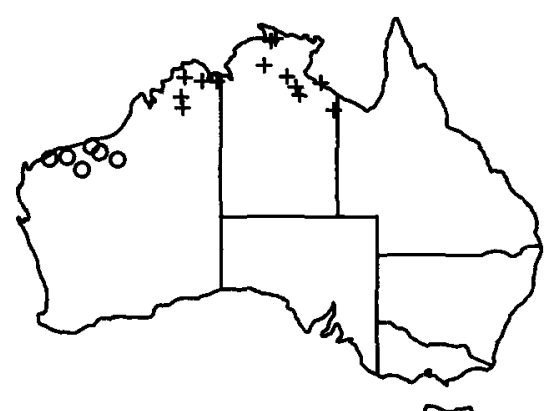

d $\square$

Figure 10. Distribution of: a, C. cunninghamii subsp. cunninghamii; b, C. cunninghamii subsp. cheradicus; c, C. cunninghamii subsp. uniflorus; d, C. astartodes (crosses) and C. hesperius (open circles). 
Territory (such as in the Keep River National Park, Katherine Gorge and the McArthur River region). Both subspecies are associated with rocky habitats but there do seem to be minor ecological differences, with subsp. uniflorus in drier situations, such as crevices on rock faces, with very shallow soil.

Subspecies cheradicus has a more distinctive habitat preference, being found only in stony and sandy beds of seasonal streams. This effectively isolates it from the other subspecies where their distributions overlap (which is only in the extreme north-east of the Kimberley and the McArthur River region of the Northern Territory, so far as known). Its morphology is close to that of subsp. cunninghamii. Spikelets are never terete but specimens with similar spikelets are found in subsp. cunninghamii. The nut falls separately from the glume but that is owing to the usual lack of viscidity and non-inrolled glume margins in subsp. cheradicus: the nuts and glumes are otherwise morphologically very similar to those of subsp. cunninghamii.

Subspecies uniflorus is vegetatively variable: from tall, relatively robust plants with broad leaves about three-quarters as long as the culms to short, slender plants with filiform leaves about twice as long as the culms. The slender plants are apparently restricted to cliff-faces with minimal soil (and, presumably, also moisture). Inflorescence features are more stable, apparently varying only in degree of branching and length of branches.

\section{Key to subspecies}

1 Spikelets always 1-flowered with the fertile glume completely enclosing the nut and rachilla (including upper internodes); inflorescences compound

1 Spikelets 1-8-flowered (if 1-flowered then the rachilla visible opposite the fertile glume, helping to enclose the nut); inflorescences simple to compound $\quad \ldots . . \quad 2$

2 Glume and rachilla tightly clasping the nut and falling as a unit; spikelet clusters \pm globose; spikelets terete to compressed, $0.7-2.0 \mathrm{~mm}$ wide; forming slender tussocks on rocky hillsides

a. subsp. cunninghamii

2 Glume and rachilla not tightly clasping nut, so that nut falls separately from glume; spikelet clusters \pm ovoid; spikelets compressed, usually broader (1.5-3.0 mm wide in side view); forming robust tussocks in sandy stream-beds

b. subsp. cheradicus

1a. C. cunninghamii subsp. cunninghamii

C. cunninghamii (C.B. Clarke) C. Gardner (1930: 12); Kükenthal (1935-36: 450); Blake (1947a: 37); Wilson (1981: 507, Figure 638F). Mariscus cunninghamii C.B. Clarke (1908: 18); Domin (1915: 443).

TYPe: Western Australia: Mainland and islands of Dampier Archipelago, NW Coast, A. Cunningham, Feb 1818; holo $\mathrm{K}$; iso ?BM (n.v., but cited by Clarke), BRI (fragm.), MEL (n.v., but mentioned by Blake in litt.).

C. umbellatus Benth. var. fasciculiger F. Muell. in Tate (1896: 181), as 'fasciculigerus'. C. fasciculiger (F. Muell.) Domin (1915: 445), in nota. Mariscus fasciculiger (F. Muell.) Domin (1915: 443). TYPE: NoRTHERN TerRITORY: Central Australia, R. Tate (Horn Expedition), 1894; lecto AD 98438048 (here designated); isolecto AD 98438047, K, NSW 22742. [Type cited as 'On rocky slopes of Mount Tate and in Stuarts Pass'. Lectotype has two field labels: 'Mt T[ate]' and 'Runnels on face Mt Paisley' (Mt Paisley is close to Stuarts Pass). 
Mariscus aridicola Domin (1915: 439), as 'aridicolus'. C. aridicola (Domin) Domin (1915: 445), as 'aridicolus'; Kükenthal (1935-36: 451). TYPE: QuEENSLAND: in collibus graminosis apud opp. Cloncurry, Domin 1772, Feb 1910; lecto PR (here designated).

Mariscus xerophilus Domin (1915: 438, Figure 101). C. xerophilus (Domin) Domin (1915: 445), in nota; Kükenthal (1935-36: 450). TYPE: QuEENSLAND: in collibus gramineis prope Cloncurry, Domin 1765, Feb 1910; lecto PR (here designated).

[C. gunnii auct. non Hook. f.: Bentham (1878: 283), p.p. min.; Ewart \& Davies (1917: 55), as to Walcott and Cunningham specimens]

\section{[C. holoschoenus auct. non R. Br.: Fitzgerald (1918: 117), p.p.]}

Slender perennial, shallow-rooted, usually viscid towards base of plant and spikelets. Culms 1-2(-3.5) $\mathrm{mm}$ diam. Leaves longer than (rarely to twice as long as) to equalling culms, to $2(-8) \mathrm{mm}$ wide; marginal prickles sparse to very sparse, regularly or irregularly spaced $(0.2-2.0 \mathrm{~mm}$ apart); sheaths stramineous to pale pink-brown or occasionally orange-brown. Inflorescence simple to compound, 2-10(-15) primary branches to $7(-18) \mathrm{cm}$ long; $2-3(-5)$ bracts much exceeding inflorescence. Spikelets numerous in \pm dense, spicate to subdigitate, \pm globose clusters of $0.5-2 \mathrm{~cm}$ diam.; spikelets terete or compressed, oblong to narrow-ovate, 3-12 mm long, 0.7-2.0 mm wide in side view, 1-4(-8)-flowered, mostly viscid at least towards the base; rachilla broadly winged with the wings $0.1-0.15 \mathrm{~mm}$ wide and clasping the nut, the rachilla visible in terete spikelets due to wide spacing of the glumes; glume spacing $2.0-4.7 \mathrm{~mm}$; spikelet falling as a unit. Glumes oblong to narrow-obovate, \pm excurved, retuse to acute with straight or excurved mucro $0.1-0.4 \mathrm{~mm}$ long, $2.6-4.5 \mathrm{~mm}$ long, $0.5-1.0 \mathrm{~mm}$ wide, sides 2-4-nerved, margins inrolled (strongly so in terete spikelets with widely spaced glumes). Anthers 0.9-1.5 mm long excluding appendage $0.1-0.2 \mathrm{~mm}$ long. Nut trigonous to triquetrous, very narrow-elliptic to narrow-elliptic or narrow-ovate, faces flat to occasionally convex, $1.7-2.4 \mathrm{~mm}$ long, $0.3-0.6 \mathrm{~mm}$ diam., falling with the glume. Figure $9 \mathrm{a}-\mathrm{c}$.

DisTRIBUTION: As for the species. Figure 10a.

HABITAT: Rocky hills, on ledges or in gullies.

The type of C. cunninghamii was probably collected on Enderby Island (Cunningham's main collecting site in the Dampier Archipelago), on which island B. Maslin recently re-collected the species (Maslin 5557), near Cunnningham's probable landing place. Cunningham also collected on Intercourse and Malus Islands and from King Bay on the adjacent mainland, so it is possible that he could have collected the species in one of those places, although Maslin did not find it there (Maslin pers. comm.).

C. umbellatus var. fasciculiger was described by Mueller from very immature plants with 1-flowered spikelets. Clarke (quoted by Domin 1915: 443) recognised that this was probably $C$. cunninghamii: 'from the nature of the bristly hairs on the involucral leaves, I think this may be the state of M.[Mariscus] cunninghamii before the spikelets have grown out'. Domin (1915) described C. aridicola and C. xerophilus as having two stamens per flower. I did not dissect any flowers on the type sheets, but I examined all other specimens from Queensland and found three stamens per flower (as is usual in this group).

Selected SPECIMENS (118 examined): QuEENSLAND: Burke: Cloncurry, Blake 6380, June 1934 (BRI, L, MEL, NSW); Lake Moondarra, NNE of Mt Isa, Wilson 5427, May 1983 (NSW, AD, BRI); Lawn Hill Creek near gorge, $16 \mathrm{~km}$ SW of Adels Grove, Wilson 5557, May 1983 (NSW). NoRTHERN TERRTIORY: Darwin and Gulf: Katherine Gorge National Park near second rapids, Craven 6752, Apr 1981 (CANB, DNA, L); $25 \mathrm{~km}$ WSW of Borroloola on Cape Crawford road, Wilson 5379, May 1983 (NSW, AD, BRI, CANB, DNA). Victoria River: Tanami Sanctuary, Henry 661, Mar 1973 (NT, BRI, CANB). Central North: Aileron Lagoon area, Chippendale 735, Dec 1954 (NT, C, CANB, MEL, 
NSW); Devils Marbles, 6 miles [10 km] N of Wauchope, Coveny 517, Aug 1968 (NSW, BRI, K, NT); Elkedra Station, Davenport Range, Latz 6954, May 1977 (NT, AD, NSW). Central South: Penny Springs, George Gill Range, Beauglehole 26807, July 1968 (NSW, NT); Longs Range, Latz 4221, Aug 1973 (NT, AD, BRI, PERTH). Western Australia: Hall: Picaninny Creek Gorge, 15 km SE of Bungle Bungle Outcamp, Bungle Bungle Range, Blackwell BB 468, Apr 1985 (PERTH, NSW). Mueller: Mt Webb, Great Sandy Desert, De Graaf 67, May 1977 (PERTH). Fortescue: Mt Edgar Station, SE from Marble Bar, Burbidge 1101, June 1941 (BRI, PERTH); 2 miles [3 km] W of Roebourne, George 3323, Feb 1962 (PERTH, BRI); Briggada Creek, Barrow Island, Goodall 1513, May 1964 (PERTH); Rocky Head, Enderby Island, Maslin 5557, Mar 1984 (NSW). Keartland: Little Sandy Desert, Mitchell 730, Apr 1979 (NT, NSW, PERTH); Rudall R. area, Curran-Curran Rock Hole, P. Wilson 10424, Aug1971 (PERTH, MEL). Giles: Walter James Range, George 8882, July 1967 (CANB, K, NSW).

1b. C. cunninghamii subsp. cheradicus K.L.Wilson, subsp. nov.

A subsp. cunninghamii nuce glumaque seorsim cadentibus, spiculis semper manifesteque compressis, differt.

TYPE: QueENSLAND: Gregory North: $20 \mathrm{~km}$ NE of Dajarra on Duchess road, K.L. Wilson 5471, 17 May 1983; holo NSW; iso BRI, K, NT, P, PERTH. Figure 11a.

[C. ixiocarpus auct. non F. Muell.: Blake (1947a: 35), p.p. min. (Brass 116)]

Tall but slender perennial, deep-rooted, forming big tussocks, occasionally viscid towards base of spikelets. Culms $1.5-2 \mathrm{~mm}$ diam. Leaves $\leq$ culms, $2.0-3 \mathrm{~mm}$ wide; marginal prickles dense to sparse, regularly spaced $(0.2-1.0 \mathrm{~mm}$ apart); leaf sheaths \pm smooth and shining, orange-brown to stramineous. Inflorescence small-compound to compound, 6-11 primary branches to $9 \mathrm{~cm}$ long; 2-3 bracts much exceeding inflorescence. Spikelets 6-15 in dense, subdigitate, ovoid clusters of $0.7-1.5 \mathrm{~cm}$ diam.; spikelets compressed, oblong, 7-10 mm long, 1.5-3.0 mm wide in side view, 2-8flowered; rachilla broadly winged, wings $0.1-0.25 \mathrm{~mm}$ wide, not clasping nut; glume spacing 2.2-3.5 mm; spikelet falling as a unit, or rachilla persistent and glumes falling individually. Glumes narrow-elliptic, retuse to acute with straight mucro $0.1-0.2 \mathrm{~mm}$ long, 3.0-4.5 mm long, c. $0.7 \mathrm{~mm}$ wide, sides 3-6-nerved, margins white-membranous and not inrolled. Anthers 1.1-2.0 mm long excluding appendage 0.2-0.3 mm long. Nut trigonous, narrow-elliptic to narrow-ovate, faces flat to slightly convex, 2.2-3.0 mm long, $0.6-0.7 \mathrm{~mm}$ diam., usually falling separately from the glume. Figure $9 \mathrm{~d}-\mathrm{f}$.

Distribution: Mainly in the Burke and Gregory North regions of Queensland and Darwin \& Gulf region of the Northern Territory, extending to the Central North region of the N.T. and the north-eastern Kimberley region of Western Australia (Figure $10 \mathrm{~b})$.

HABITAT: In sandy and stony beds of seasonal streams.

The epithet comes from the Greek cheras, cherados, gravel or silt brought down by a river, referring to the habitat in which this subspecies is found.

Subspecies cheradicus differs from the type subspecies in the generally more robust habit (but leaves always canaliculate, never flat); spikelets in ovoid clusters (not globose); the obviously compressed spikelets (but cf. some specimens of subsp. cunninghamii), which are mostly broader and less viscid; glume and rachilla not enclosing nut closely (and nut usually falling separately from glume); glume nerves often more numerous and finer, midrib usually thinner, mucro short.

SPECIMENS EXAMINED: QueENSLAND: Burke: Dugald R. area, c. $64 \mathrm{~km}$ NW of Cloncurry, Beaumont 7129, Sep 1971 (BRI); Cloncurry, Blake 6350, June 1934 (BRI, K); Leichhardt R., Mt Isa, Blake 8754, Apr 1935 (BRI, K, MEL, NSW, NT, PERTH); Coolullah, Leichhardt R., Blake 9296, June 1935 (BRI, K); Adels Grove via Camooweal, De Lestang 276, Jan 1947 (BRI); Lake Moondarra road, Mt Isa, 

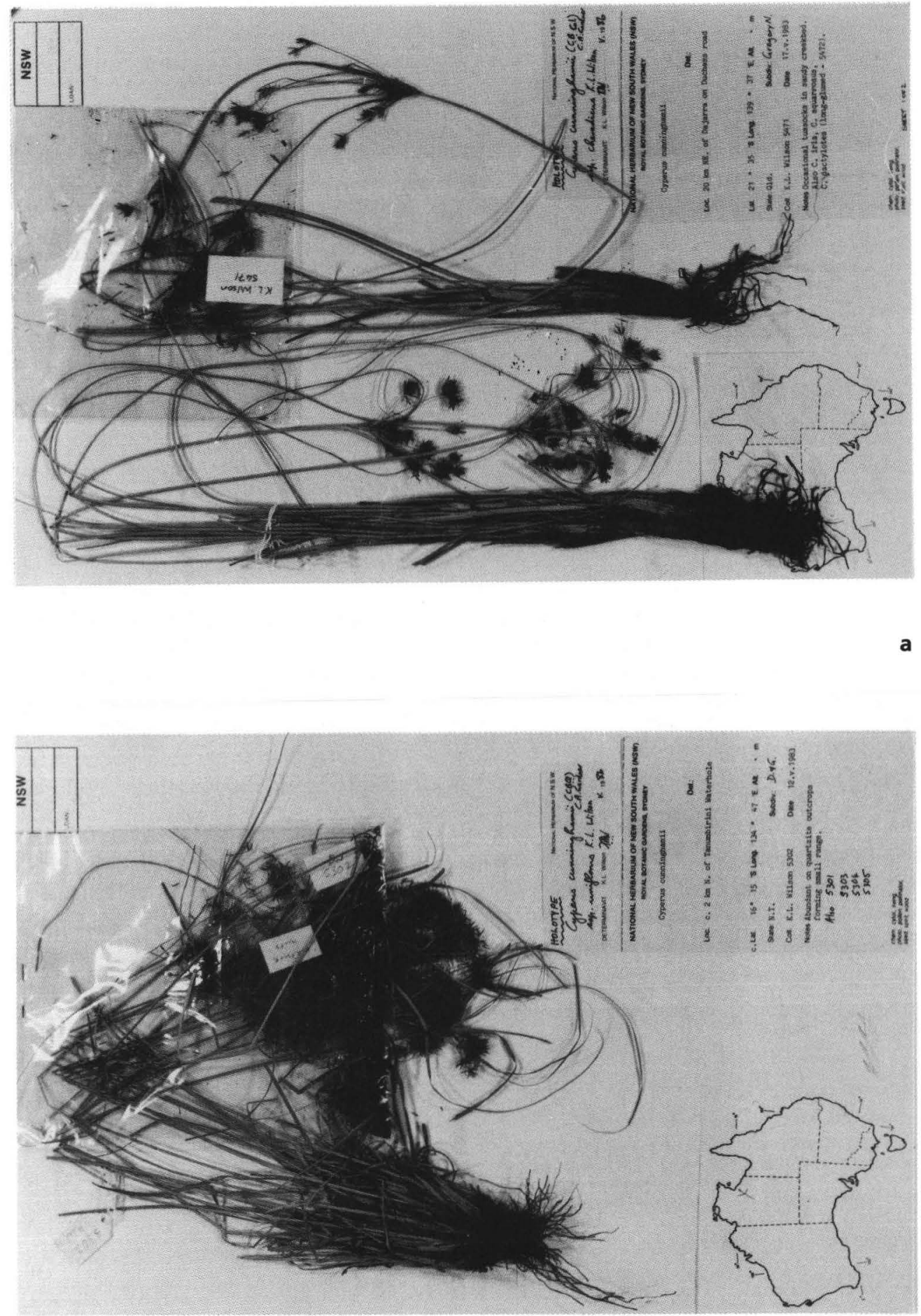

Figure 11. Holotype of a, C. cunninghamii subsp. cheradicus; b, C. cunninghamii subsp. uniflorus. 
Finlayson 77, 78, Feb 1978 (NSW); Leichhardt R. bed, 2 km W of Coolullah crossing, Schmid 392, Feb 1978 (BRI, DNA); $21 \mathrm{~km} \mathrm{~S}$ of Mt Isa on Duchess road, Wilson 5449, May 1983 (NSW, BRI, CANB); 13 km NNE of Thorntonia HS. on Burketown road, Wilson 5495, May 1983 (NSW, BRI, K); Little Crèek, 19 km NW of Riversleigh HS., Wilson 5542, May 1983 (NSW, BRI, DNA, PERTH). Gregory North: $22 \mathrm{~km} \mathrm{~N}$ of Wills Creek on Duchess-Mt Isa road, Wilson 5454, May 1983 (NSW, AD, BRI, NT); $20 \mathrm{~km}$ NE of Dajarra on Duchess road, Wilson 5471, May 1983 (NSW). NORTHERN TERRITORY: Darwin and Gulf: Settlement Creek, Brass 116, Jan 1922 (BRI, CANB); McArthur R. area, Amelia Springs, Craven 4201, June 1976 (CANB). Central North: Old Hatches Creek, Latz 2221, Feb 1972 (NSW); 22 km NE of Devils Marbles, Latz 9491, Apr 1983 (NSW); Stuart Highway, $8 \mathrm{~km}$ N of Wauchope, Wilson 4668, Apr 1983 (NSW). WeSTERN AUSTRALIA: Gardner: Granite Creek, $11.7 \mathrm{~km}$ SW of Victoria Highway, Wilson 4894, Apr 1983 (NSW, AD, DNA, PERTH).

1c. C. cunninghamii subsp. uniflorus K.L. Wilson, subsp. nov.

A subsp. cunninghamii spiculis semper unifloribus, gluma fertili nucem rhachillamque perfecte includenti, inflorescentia grande composita, differt.

TYPE: NORTHERN TERRITORY: Darwin and Gulf: c. 2 km N of Tanumbirini Waterhole, K.L. Wilson 5302, 12 May 1983; holo NSW; iso BRI, K, NT, NY, P, PERTH. Figure 11b.

Slender perennial, shallow-rooted, usually viscid towards base of leaves and spikelets. Culms 1-2 mm diam. Leaves somewhat thickened, somewhat curly, longer than (to twice as long as) or equalling culms, to $3.5 \mathrm{~mm}$ wide; marginal prickles dense to very sparse, mostly irregularly spaced (0.4-2.0 mm apart); leaf sheaths pinkish brown to orange-brown. Inflorescence compound, $8-15$ primary branches to $8 \mathrm{~cm}$ long; 2-3 bracts much exceeding inflorescence. Spikelets 5-12(-15) in small, loose, subdigitate, hemispherical to globose clusters of $0.5-1.0 \mathrm{~cm}$ diam.; spikelets terete, linear, $2.5-4 \mathrm{~mm}$ long, $0.3-0.5 \mathrm{~mm}$ wide in side view, 1-flowered; rachilla broadly winged, with the wings 0.1-0.2 mm wide and clasping the nut; spikelet falling as a unit usually, or commonly units of ultimate branch plus spikelets falling. Glumes very narrow-elliptic, retuse to acute with \pm straight mucro $<0.1-0.2 \mathrm{~mm}$ long, $2.5-3.5 \mathrm{~mm}$ long, $0.5-0.6 \mathrm{~mm}$ wide, sides 2-4-nerved, margins strongly inrolled and narrow-membranous. Anthers $0.5-1.5 \mathrm{~mm}$ long excluding appendage $0.2-0.5 \mathrm{~mm}$ long. $N u t$ triquetrous, very narrow-elliptic to very narrow-ovate, faces flat, $1.7-2.3 \mathrm{~mm}$ long, $0.3-0.4 \mathrm{~mm}$ diam., falling with the glume. Figure $9 \mathrm{~g}-\mathrm{i}$.

Distribution: Eastern Kimberley region of Western Australia, and Victoria River and Darwin \& Gulf regions of the Northern Territory. Figure 10c.

HABITAT: In crevices on quartzite outcrops or occasionally at the base of boulders. Specimens growing on rock faces are often weeping in habit, with very long leaves and involucral bracts.

The epithet is from the Latin unus, $-a,-u m$, one and flos, floris, a flower, referring to the single-flowered spikelets.

Differs from subsp. cunninghamii in the always one-flowered spikelets, with the fertile glume completely enclosing the rachilla and nut; the thin midrib and regularly short mucro to the glume; and the usually relatively large compound inflorescence.

SElECTED SPECIMENS (24 examined): NORTHERN TERRITORY: Darwin and Gulf: Hodgson Downs Station, Blake 17542, Apr 1947 (BRI, K, L, MEL, NSW); McArthur R. area, sandstone plateau near Glyde R., Craven 3503, Jan 1976 (CANB, NT); Katherine Gorge National Park, Craven 6700, Apr 1981 (CANB, DNA), Wilson 5249, May 1983 (NSW); Bukalara Plateau, NE of Glyde R., Rice 2339, Feb 1976 (CANB); Edith Falls, Wilson 4964, Apr 1983 (NSW). Victoria River: Jasper Gorge, Beauglehole $\mathcal{E}$ Carr 46580, July 1974 (ACB, NT); Keep River National Park, Dunlop 5842, Mar 1981 (DNA, NSW, PERTH). WeSTERN Australia: Gardner: near Kimberley Research Station, Burbidge 5708, 5709, Apr 1958 (CANB, BRI, PERTH); sandstone outlier NW of Deception Range, Hartley 14786, Mar 1978 (NSW, PERTH); 24 km NE of Dunham River HS., Lazarides 8524, Mar 1978 (CANB, BRI, K, L, NSW, NT, PERTH); Hidden Valley, 2.5 km NNE of Kununurra, Wilson 4790, Apr 1983 


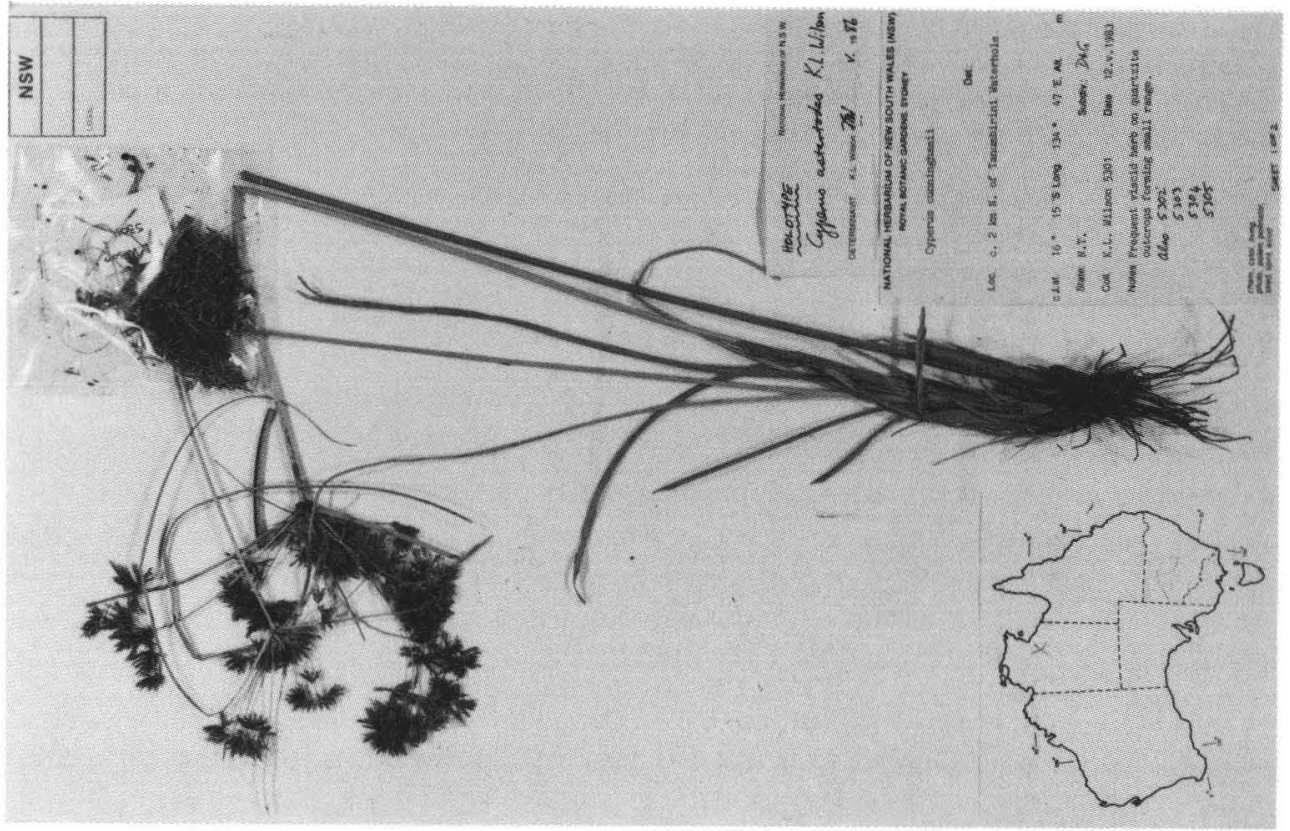

a

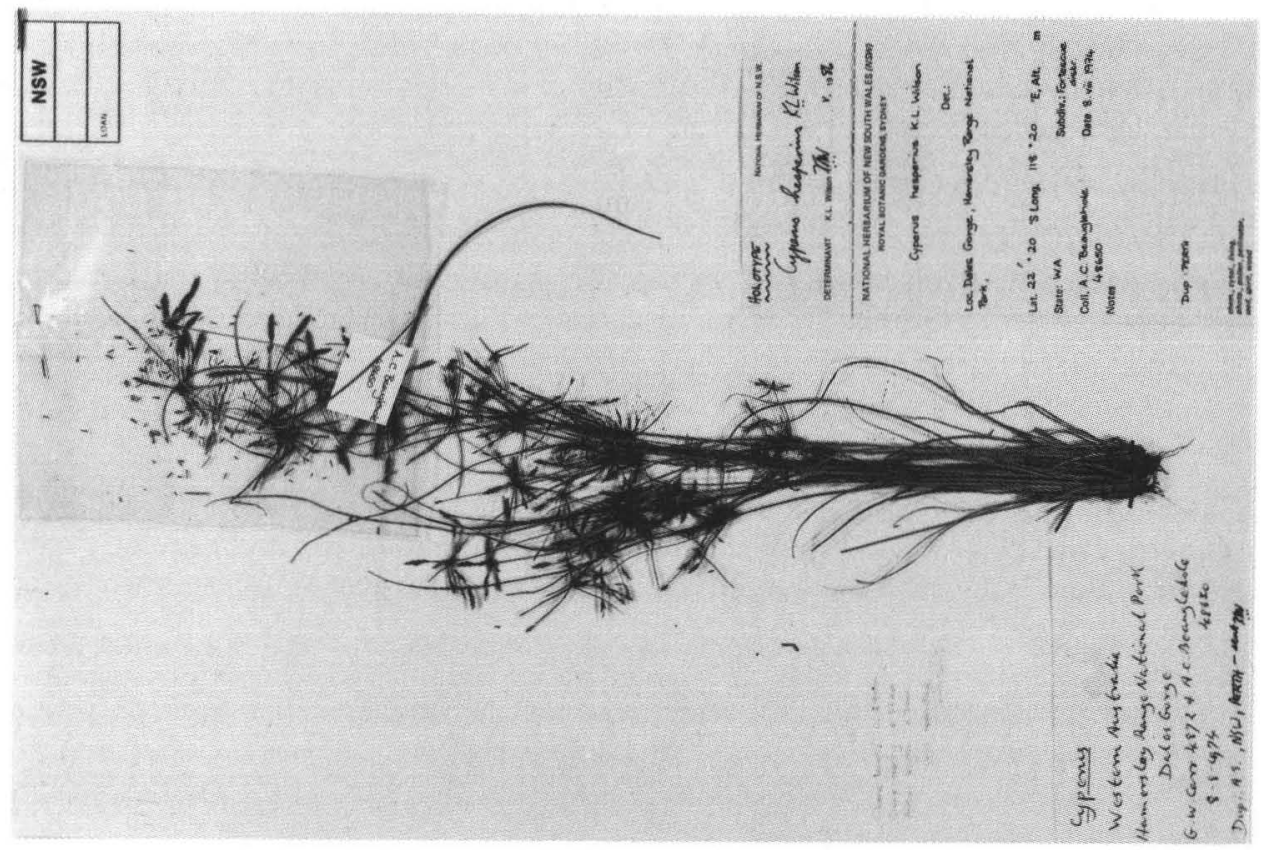

Figure 12. Holotype of a, C. astartodes; b, C. hesperius. 
(NSW); $11 \mathrm{~km} \mathrm{~N}$ of Kununurra just off Weaber Plains road, Wilson 4805, Apr 1983 (NSW); 20 km S of Great Northern Highway on Moochalabra Dam road, Wilson 4864, Apr 1983 (NSW). Hall: Picaninny Creek Gorge, $15 \mathrm{~km}$ SE of Bungle Bungle Outcamp, Bungle Bungle Range, Blackwell BB 49, 280, Apr 1985 (NSW, PERTH); SE Kimberley region, summit NE arm Bungle Bungle massif, Forbes 2636S, July 1984 (NSW ex MEL).

\section{Cyperus astartodes K.L. Wilson, sp. nov.}

C. cunninghamii et $C$. microcephali affinis, sed a C. cunninghamii rhachilla exalata differt; a C. microcephalo rhachilla non crasso, nuce glumaque seorsim cadentibus, differt.

TYPE: NORTHERN TERRITORY: Darwin and Gulf: c. $2 \mathrm{~km}$ N of Tanumbirini Waterhole, K.L. Wilson 5301, 12 May 1983; holo NSW; iso BRI, DNA, K. Figure 12a.

C. holoschoenus R. Br. var. viscidus W.V. Fitzgerald (1918: 117). TYPE: WESTERN Australia: summit of Mt Leake, Lady Forrest Range, W.V. Fitzgerald 1201, July 1905; lecto PERTH (here designated); isolecto CANB, NSW.

[C. cunninghamii auct. non (C.B. Clarke) C. Gardner: Blake in Specht \& Mountford (1958: 202).]

More or less robust perennial, tufted, (30-)50-100 cm high, spikelets often (and base of plant occasionally) viscid. Culms terete to trigonous, usually smooth, 2-4.5 mm diam. Leaves flat or canaliculate, septate-nodulose, < culms, to $5.5(-11) \mathrm{mm}$ wide; midrib \pm obvious abaxially, scabrous or smooth, dark yellow-green; marginal prickles dense to very sparse, mostly regularly spaced $(0.2-1.7 \mathrm{~mm}$ apart), short, $0.05-0.10 \mathrm{~mm}$ long, erect to antrorse or occasionally retrorse, papillate to aculeate; leaf sheaths not septatenodulose, finely striate but somewhat shining, stramineous to pale orange-brown. Inflorescence compound to decompound, 9-20 primary branches to $19 \mathrm{~cm}$ long; bracts spreading, 2-5 much exceeding the inflorescence. Spikelets 3-7 in rather loose, subdigitate, hemispherical clusters of $0.8-3 \mathrm{~cm}$ diam.; spikelets compressed, oblong, 6-19 $\mathrm{mm}$ long, $1.5-2.0 \mathrm{~mm}$ wide in side view, 3-8(-22)-flowered, often viscid; rachilla not thickened, not or narrowly winged, wings to $0.05 \mathrm{~mm}$ wide; glume spacing (1.3-)1.5-2.1 mm; spikelet falling as a unit, or rachilla persistent and glumes falling individually. Glumes narrow-elliptic, obtuse to acute with straight mucro $0.1-0.2 \mathrm{~mm}$ long, golden-brown to red-brown, 2.2-2.7 mm long, 0.5-0.6 mm wide, sides 2-3-nerved, margins slightly inrolled and broad-hyaline. Anthers $0.7-1.2 \mathrm{~mm}$ long excluding appendage $<0.1-0.2 \mathrm{~mm}$ long. Nut trigonous to triquetrous, very narrow-elliptic to narrow-ovate with acute apex, faces flat, pale brown to red-brown or occasionally dark red-brown, smooth and reticulate-areolate or tuberculate, glistening, 1.5-2.1 mm long, $7 / 8$ as long as to equalling glume, $0.3-0.5 \mathrm{~mm}$ diam., falling with the glume. Figure $9 \mathrm{j}-1$.

DisTRIBUTION: Gardner and Fitzgerald regions of Western Australia to Darwin \& Gulf and Barkly Tableland of the Northern Territory. Figure 10d.

HABITAT: Sandy soils; around rock outcrops in open woodland or on open rocky slopes.

The epithet is derived from the name of the Phoenician goddess of fertility and love, Astarte, and the Greek -odes, resembling or like, referring to the large, floriferous inflorescences. Fitzgerald's varietal epithet was not taken up because there could be confusion with C. viscidulus. Also, it is not particularly appropriate for this species, which is only occasionally viscid.

Differs from C. cunninghamii in its generally robust habit with large compound inflorescence, always compressed spikelets (and generally broader) with more flowers, 
often wingless rachilla, generally shorter glumes, its marginal prickles, and generally paler nut (although darker and broader in Wilson 5151).

From C. microcephalus, it differs in its more robust habit, longer glumes, usually greater glume spacing, rachilla not thickened, glumes clasping nut, sparse variable marginal prickles on the leaves, nut paler and longer, and often viscid spikelets (and occasionally plant base as well).

The species occasionally occurs with C. cracens (q.v.).

SPECIMENS EXAMINED: NoRTHERN TeRrITORY: Darwin and Gulf: Hodgson Downs Station, Blake 17543, Apr 1947 (BRI, K, NSW); O.T. Station, Blake 17678, May 1947 (BRI, K, NSW); Mt Brockman near Koongarra Saddle, Craven 5744, May 1980 (CANB); Katherine Gorge National Park, Dunlop \& Byrnes 2165, Mar 1971 (BRI, CANB, DNA, NT); Nicholson R. area, near Fish R. gorge in China Wall, Kanis 1760, June 1974 (CANB, NT); Tanumbirini Creek, Cox River Station, Latz 7302, July 1977 (NT, BRI, NSW); SW Island, McKey 199, May 1977 (NT, NSW); Buchanan Bay, McKey 203, May 1977 (NT, BRI, NSW); South Bay, Bickerton Island, Specht 649, June 1948 (CANB, BRI, K, MEL, NSW, PERTH); 50 km E Oenpelli, Wightman 679, Aug 1983 (DNA); Edith Falls, Wilson 4965, Apr 1983 (NSW); c. $17 \mathrm{~km}$ N of Mudginberri turn-off on Oenpelli road, Wilson 5151, May 1983 (NSW). Western Australia: Gardner: Rocky Creek, c. $60 \mathrm{~km} \mathrm{~N}$ of Drysdale River, Benson 2088a, July 1984 (NSW); Cave Hill Range, near Kununurra, Wolfe $\mathcal{E}$ Martin 37, May 1970 (CANB). Fitzgerald: Fitzgerald 1201 (PERTH, CANB, NSW); Mt Barnett Station, summit escarpment Barnett Range, Forbes 2750, July 1984; Durack River, Hartley 14652, Mar 1978 (CANB, NT, PERTH).

\section{Cyperus hesperius K.L. Wilson, sp. nov.}

C. microcephali affinis sed glumis latioribus ellipticisque, marginibus glumae latiore hyalinis, foliis non crispatis, marginibus foliorum papillosis, differt.

TyPe: Western Australia: Fortescue: Dales Gorge, Hamersley Range National Park, A.C. Beauglehole 48650 \& G.W. Carr 4872, 8 Aug 1974; holo NSW; iso ACB, NT, PERTH. Figure 12b.

Slender perennial, tufted, $30-40 \mathrm{~cm}$ high, not viscid. Culms terete to trigonous, smooth, 1-1.5 mm diam. Leaves canaliculate, not septate-nodulose, shorter than culms, to 2.5 $\mathrm{mm}$ wide; midrib occasionally obvious abaxially; marginal prickles dense, regularly spaced $(0.05-0.3 \mathrm{~mm}$ apart), very short to short, no more than $0.05 \mathrm{~mm}$ long, erect to slightly antrorse, papillate; leaf sheaths not septate-nodulose, \pm smooth and shining, stramineous to pale pink-brown. Inflorescence simple or small-compound, (1-)4-7 primary branches to $11 \mathrm{~cm}$ long; bracts erect to spreading, 2-4 exceeding the inflorescence. Spikelets 6-20 in loose subdigitate, hemispherical clusters of 2-5 cm diam.; spikelets compressed, oblong, 8-25 mm long, $2 \mathrm{~mm}$ wide in side view, (4-)8-26flowered; rachilla thickened at maturity (to $0.2 \mathrm{~mm}$ thick), not or narrowly winged, wings to $0.05 \mathrm{~mm}$ wide; glume spacing $1.5-1.8 \mathrm{~mm}$; spikelet with rachilla persistent and glumes falling individually. Glumes narrow-elliptic to narrow-ovate, retuse to acute, with straight mucro $0.2-0.3 \mathrm{~mm}$ long, golden-brown to red-brown with green midrib, 2.4-2.8 mm long, 0.5-0.6 mm wide, sides 2-3-nerved, margins broad- to narrowhyaline and mostly not inrolled. Anthers $0.3-0.8 \mathrm{~mm}$ long excluding appendage $0.2-$ $0.4 \mathrm{~mm}$ long. Nut trigonous to triquetrous, narrow-elliptic (to narrow-ovate) with acute apex, faces flat, red-brown to black, small-colliculate to tuberculate, glistening, 1.5-1.8 mm long, $2 / 3-3 / 4$ as long as glume, $0.4-0.5 \mathrm{~mm}$ diam., mostly falling with glume. Figure $9 \mathrm{~m}-\mathrm{O}$.

DistRIBUTION: Pilbara region of Western Australia. Figure 10d.

HABITAT: On open rocky hillsides so far as known. 
The epithet is derived from the Greek hesperios, at eventide or towards the setting sun, and hence by transference western, referring to the species' occurrence only in the Pilbara region of Western Australia.

Allied to C. microcephalus, especially the type subspecies (which also occurs in the Pilbara), but differing from it in its broader elliptic glumes with broader hyaline margins, and its straight (not curly) leaves with papillate margins. C. cunninghamii subsp. cunninghamii also grows in the Pilbara, but differs in its broadly winged rachilla and its sparse, long prickles on the leaf margins.

SPecimens examined: WeStern Australia: Fortescue: $61 \mathrm{~km}$ SE of Port Hedland on Marble Bar road, Beauglehole 11352, Aug 1965 (NSW, NT); Dales Gorge, Hamersley Range National Park, Beauglehole 11490, Aug 1965 (ACB), George 3575, Mar 1962 (BRI, NSW); Chichester National Park, Python Pool, Beauglehole 48826 \& Carr, Aug 1974 (NT); Robe R. between Onslow and Roebourne, Butler 29, Aug 1966 (PERTH); $16 \mathrm{~km}$ SSW of Two Sisters, c. $180 \mathrm{~km}$ SE of Shay Gap, Newbey 10410, July 1984 (PERTH); Abydos Station, S of Port Hedland, Richardson 29, Sep 1968 (PERTH); Hamersleys, Wittenoom Gorge, Symon 10034, May 1975 (PERTH).

\section{Cyperus microcephalus $R . B r$.}

Brown (1810: 215)

Perennial, generally slender, tufted, $20-85 \mathrm{~cm}$ high, not viscid. Culms terete to trigonous, often strongly scabrous at least near apex, $0.3-4 \mathrm{~mm}$ diam. Leaves flat, or canaliculate in slender specimens, may be septate-nodulose in large specimens, shorter than to longer than culms, to $7 \mathrm{~mm}$ wide, yellow-green; midrib obvious abaxially (and then usually scabrous) or not obvious; marginal prickles very dense, regularly spaced $(<0.05-0.5 \mathrm{~mm}$ apart), very short to short, $<0.05-0.10 \mathrm{~mm}$ long, antrorse, aculeate; leaf sheaths may be septate-nodulose in large specimens, smooth or finely striate, not shining, stramineous to salmon-coloured or orange-brown. Inflorescence simple to decompound, 0-15 primary branches 1-14 cm long; bracts erect to spreading, 1-7 exceeding the inflorescence. Spikelets 3-15 in loose subdigitate, hemispherical clusters of $0.5-1.5(-5.0) \mathrm{cm}$ diam.; spikelets compressed, \pm oblong, 3-10(-30) $\mathrm{mm}$ long, 1.0-3.0 mm wide in side view, 3-10(-32)-flowered; rachilla usually thickened at maturity (to $0.3 \mathrm{~mm}$ thick), not to rarely broadly winged, with wings to $0.15 \mathrm{~mm}$ wide; glume spacing $0.8-2.1 \mathrm{~mm}$; spikelet falling as a unit, or with rachilla persistent and glumes falling individually, or units of ultimate branch plus spikelets falling. Glumes narrow-elliptic to very narrow-ovate, acute to obtuse or retuse with straight or slightly excurved mucro $<0.1-0.4 \mathrm{~mm}$ long, stramineous to dark golden- or pale red-brown (often with yellow blotches, especially when young), with a green midrib, 1.2-3.6 mm long, 0.2-0.7 mm wide, sides 1-4-nerved, margins very narrow-membranous and not inrolled. Anthers $0.3-1.0 \mathrm{~mm}$ long excluding appendage $0.1-0.6 \mathrm{~mm}$ long. Nut trigonous to triquetrous, narrow-obovate to narrow-ovate with acute apex, faces concave to flat, red-brown to black, smooth or tuberculate or colliculate, glistening or shining, 1.3-1.8 $\mathrm{mm}$ long, from half as long as to slightly exceeding the glume, 0.2$0.7 \mathrm{~mm}$ diam., falling separately from glume. Figure 13a-i.

DistRIBUtion: Northern Australia, extending to the Pilbara region of Western Australia and North Kennedy District of Queensland. Figures 14a-c.

Occasionally found growing near C. cunninghamii or C. astartodes (q.v.) but readily distinguished from them by its thickened rachilla, the shorter anthers with long appendage, and the short dense prickles on the leaf margins. In addition, the glumes in C. microcephalus have very narrow margins, which are not inrolled, and the nut falls separately from the associated glume. These features are shared by the three taxa treated here as subspecies, with differences between the taxa being quantitative as 
much as qualitative. Despite some overlaps in distribution, the taxa are, I believe, best treated as subspecies, at least pending further study.

Subspecies chersophilus is more clearly defined morphologically than subsp. saxicola. In addition, subsp. chersophilus is more distinct than the other subspecies in its habitat preference and geographical distribution.

Subspecies saxicola may represent no more than a depauperate form (or forms) of subspecies microcephalus but it does seem to be consistently different from the latter in its curly leaves, slender habit, and triquetrous nut with flat faces. Specimens from. Arnhem Land differ further somewhat (see below under subsp. saxicola) and may represent a separate taxon. Subspecies saxicola occurs in close proximity to subsp. microcephalus in various localities on the south-western margin of Arnhem Land (e.g. Edith Falls and Katherine Gorge) and to the south-east (Caranbirini Waterhole and
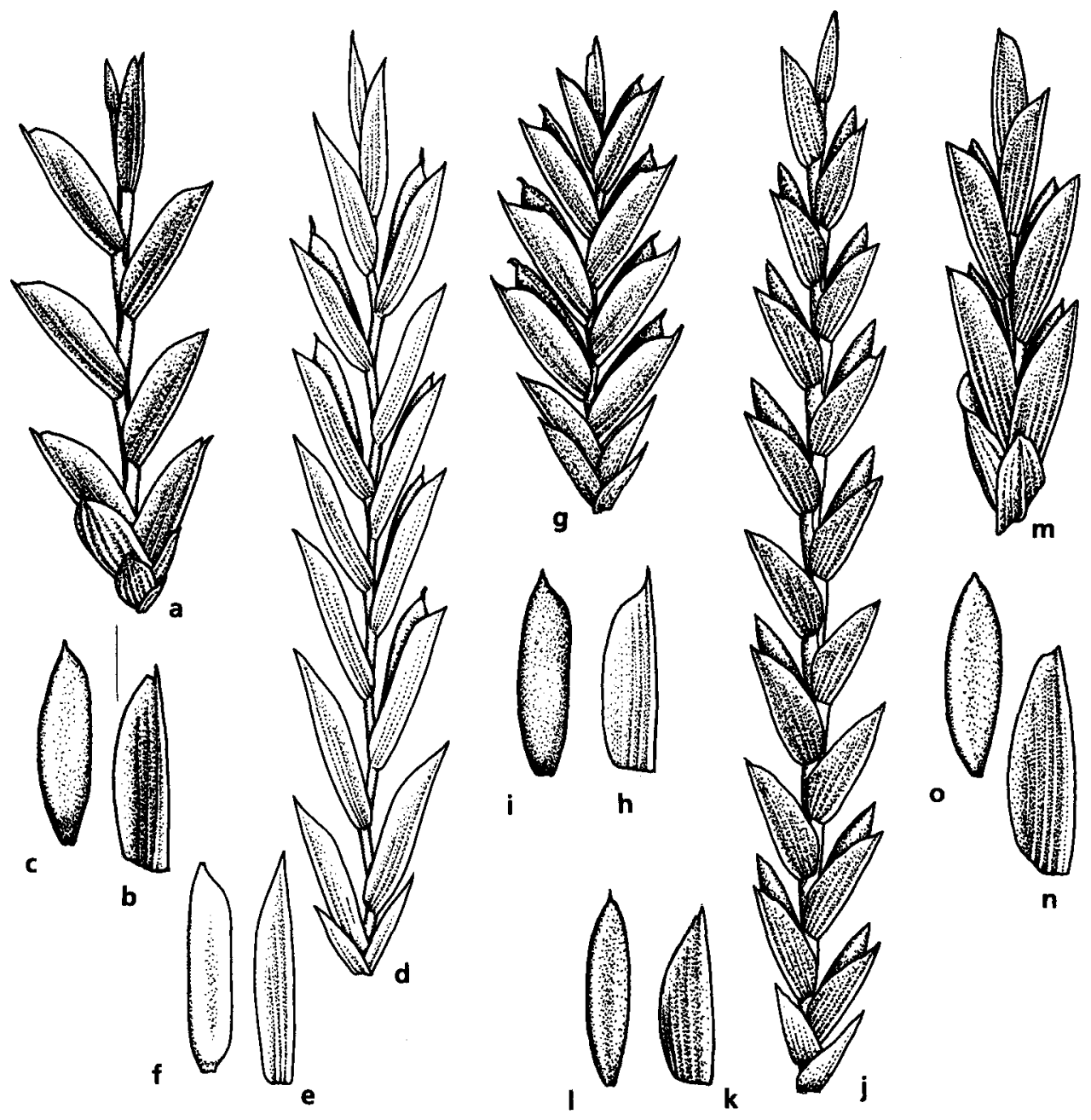

Figure 13. Spikelet details. C. microcephalus subsp. microcephalus: a, spikelet; b, glume; $\mathbf{c}$, nut. $C$. microcephalus subsp. chersophilus: d, spikelet; e, glume; $\mathbf{f}$, nut. C. microcephalus subsp. saxicola: $\mathbf{g}$, spikelet; $\mathbf{h}$, glume; $\mathbf{i}$, nut. C. crispulus: $\mathbf{j}$, spikelet; $\mathbf{k}$, glume; $\mathbf{1}$, nut. C. sexflorus: $\mathbf{m}$, spikelet; $\mathbf{n}$, glume; o, nut. a-c from Dunlop 5325; d-f Wilson 4890; g-i Latz 2734; j-l Dunlop 4441; m-o De Lestang 338. a, d, g, j, m X 11; b, c, e, f, h, i, k, l, n, o X 14 . 
the McArthur River region). However, there appear to be minor differences in habitat, with subsp. saxicola being in slightly drier situations, such as crevices on rock faces, with very shallow soil. The distribution of subsp. saxicola is interrupted: no specimens are known from the north-east Kimberley and the Victoria River region of the Northern Territory. There would appear to be suitable habitats in those areas for the subspecies, which may indicate inadequate collecting or perhaps a taxonomic problem. Further field study is needed to resolve this.

Bentham (1878) considered that $C$. sexflorus and $C$. sporobolus might be no more than varieties of this species (based solely on R. Brown's rather immature specimens). However, the bulbous culm-bases of these two species readily distinguish them from C. microcephalus.

\section{Key to subspecies}

1 Leaves flat (or canaliculate when slender) with abaxial midrib obvious and usually scabrous, not curly, (1.0-)1.5-7 mm wide; culms to $4 \mathrm{~mm}$ diam., [mostly strongly scabrous at least near apex]; inflorescence small-compound to decompound with primary branches to $14 \mathrm{~cm}$ long; nut faces concave or occasionally flat

a. subsp. microcephalus

1 Leaves canaliculate (occasionally flat in subsp. chersophilus), curly, 0.3-2.0 mm wide; culms no more than $1.5 \mathrm{~mm}$ diam.; inflorescence usually simple, with primary branches to $8 \mathrm{~cm}$ long; nut faces flat

2 Glumes (2.0-)2.4-3.6 mm long; culms usually scabrous; spikelets (6-)10-30 mm long, 2.0-3.0 mm wide in side view; nut trigonous, no more than $3 / 4$ glume length

b. subsp. chersophilus

2 Glumes 1.0-2.0 mm long; culms smooth; spikelets 3-11 mm long, 1.2-2.0 mm wide in side view; nut triquetrous, as long as or slightly exceeding nut

c. subsp. saxicola

4a. C. microcephalus subsp. microcephalus

C. microcephalus R. Brown (1810: 215); Poiret (1817: 187); Sprengel (1824: 227); Kunth (1837: 111); Steudel (1854: 54); Domin (1915: 432). C. sporobolus var. microcephalus (R. Br.) Benth. ex Kükenthal (1935-36: 457).

TYPE: NoRTHERn TerRITORY: Carpentaria island h [North Island, Sir Edward Pellew Groupl, R. Brown (Bennett 5902); lecto BM (here designated); isolecto BM, BRI (fragm.), $\mathrm{K}$.

[C. distans auct. non L.f.: Fitzgerald (1918: 117)]

[C. fulvus auct. non R. Br.: Mueller (1874: 268), p.p.]

[C. holoschoenus auct. non R. Br.: Fitzgerald (1918: 117), p.p. (Denham River)]

[C. sporobolus auct. non R. Br.: Bentham (1878: 281), p.p. min.; Ewart \& Davies (1917: 56), p.p. min.; Fitzgerald (1918: 117), p.p. min. (Hughan, NW Coast)]

Tall but slender perennial, $25-85 \mathrm{~cm}$ high. Culms usually strongly scabrous at least near apex, 0.7-4 mm diam. Leaves flat, or occasionally canaliculate in slender specimens, septate-nodulose in large specimens, $\leq$ culms, (1.0-)1.5-7 mm wide; midrib usually obvious abaxially and scabrous; leaf sheaths may be septate-nodulose in large specimens, stramineous to pink-brown. Inflorescence usually large, small-compound to decompound, spreading, 4-15 primary branches to $14 \mathrm{~cm}$ long; bracts erect to spreading, 3-7 exceeding the inflorescence. Spikelets 3-8 in loose clusters of 0.8-1.5 $\mathrm{cm}$ diam.; spikelets 3-7(-15) $\mathrm{mm}$ long, 1.0-2.5 mm wide in side view, 3-10(-26)- 
flowered; rachilla not to rarely broadly winged, wings $0.05-0.10 \mathrm{~mm}$ wide; glume spacing $0.8-1.6 \mathrm{~mm}$. Glumes narrow-elliptic to narrow-ovate, acute to obtuse with straight mucro $<0.1-0.2 \mathrm{~mm}$ long, $1.5-2.0 \mathrm{~mm}$ long, $0.4-0.6 \mathrm{~mm}$ wide, sides 2-4-nerved. Anthers $0.5-1.0 \mathrm{~mm}$ long excluding appendage $0.2-0.6 \mathrm{~mm}$ long. $N u t$ trigonous to triquetrous, narrow-obovate to narow-ovate, faces concave or occasionally flat, redbrown to very dark red-brown, smooth and reticulate-areolate or tuberculate, shining or glistening, about as long as the glume, 0.4-0.7 mm diam. Figure 13a-c.

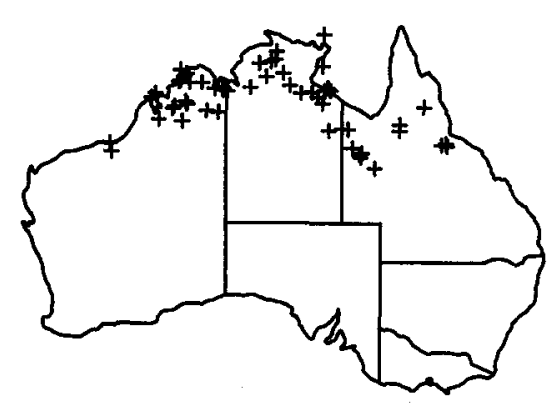

a

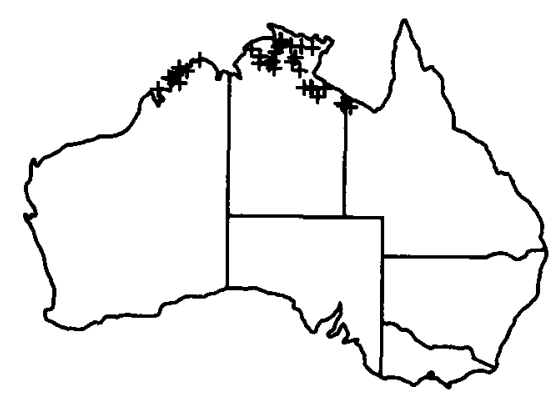

c

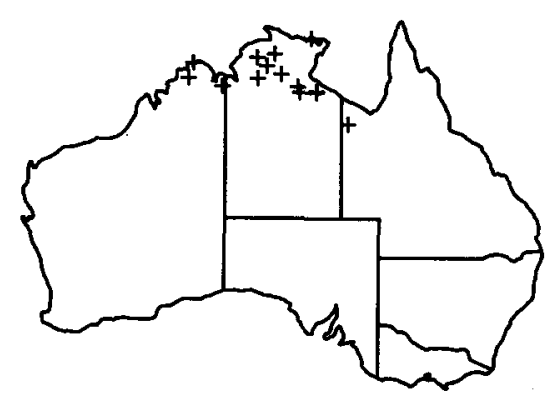

e $\square$

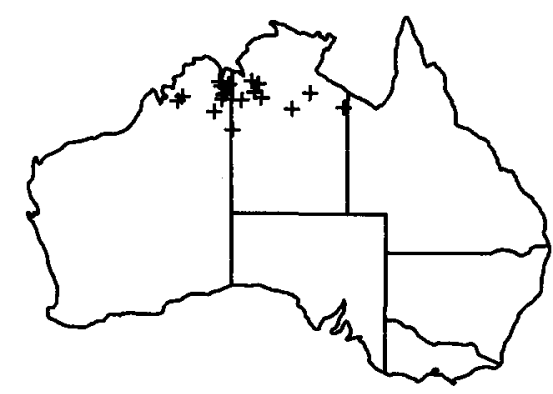

b

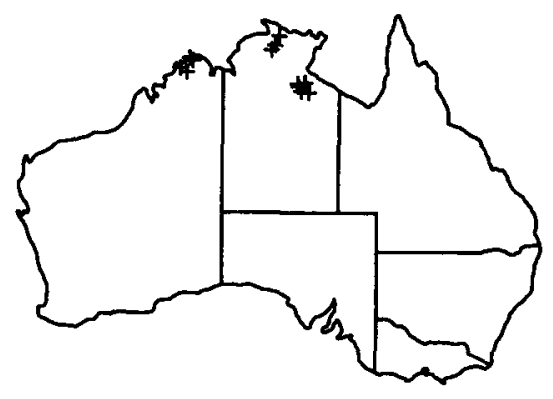

d

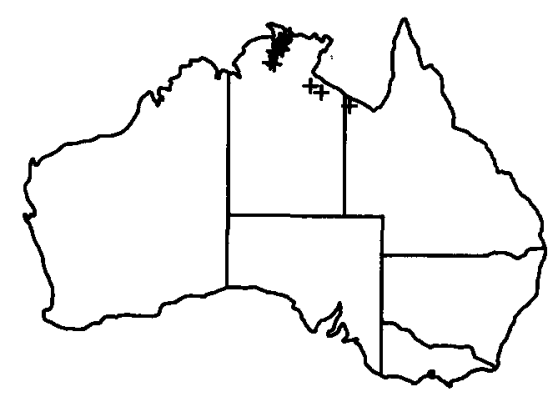

$+0$

Figure 14. Distribution of: a, C. microcephalus subsp. microcephalus; b, C. microcephalus subsp. chersophilus; $\mathbf{c}$, C. microcephalus subsp. saxicola; d, C. crispulus; e, C. sexflorus; f, C. portae-tartari. 
Distribution: As for the species. Figure 14a.

НавітAт: Amongst boulders on hillsides or on scree slope at base of cliffs.

This subspecies usually has very dense prickles on the leaf margins, but they are occasionally sparser, for example at the eastern end of its range in Queensland (Sharpe 2784, 2868). Queensland specimens also tend to have larger glumes. Sharpe 2891 (Burdekin River close to Keelbottom Mountain) and Blake 11703 (Charters Towers) probably belong here but have longer glumes (2.3-2.6 $\mathrm{mm}$ long) with finer nervation, and leaf margins with sparser but long antrorse and/or flabellate prickles.

Selected SPECimens (99 specimens examined): QueEnSLAND: Burke: Mt Isa, Blake 8800, Apr 1935 (BRI, K, L, MEL); Gregory Range E of Croydon, Blake 19666, July 1954 (BRI). North Kennedy: Burdekin R., $40 \mathrm{~km}$ N of Charters Towers, $2 \mathrm{~km} \mathrm{~S}$ of Keelbottom Mountain, Sharpe 2784, June 1981 (BRI, NSW); Red Falls, on Lolworth R., 55 km NW of Charters Towers, Sharpe 2868, July 1981 (BRI, NSW). NORTHERN TERRITORY: Darwin and Gulf: N side of Mt Brockman, Craven 2348, Feb 1973 (CANB, BRI, NT, PERTH); McArthur R. area, near the Glyde R., Craven 3561, Jan 1976 (CANB); South West I., Sir Edward Pellew Group, Craven 3751, Feb 1976 (CANB, BRI, L, NT); Wessel Islands, Latz 3478, Oct 1972 (BRI, CANB, NT); Katherine Gorge National Park, Wilson 5251, May 1983 (NSW, DNA); Maude Creek goldfield, $32 \mathrm{~km}$ E of Katherine, I. Wilson 174, Jan 1965 (CANB, BRI, L, NT). Victoria River: hills above and to E of Victoria R., old crossing, Bynoe Range, Carolin 6624, May 1968 (SYD); Keep River National Park, Dunlop 5735, Feb 1981 (DNA, NSW, NT). Barkly Tableland: 27 miles [43 km] E of Alexandria Station, Perry 1503, June 1948 (CANB, BRI, K, MEL, NT). WESTERN Australia: Gardner: Mitchell Plateau, Beard 8429, Feb 1979 (PERTH, NSW); Boiga Falls, Drysdale R. National Park, Kenneally 3022, Aug 1975 (PERTH); Hidden Valley, $2.5 \mathrm{~km}$ NNE of Kununurra, Wilson 4795, Apr 1983 (NSW); Osborne I. (South West I.), Bonaparte Archipelago, P. Wilson 11042, June 1973 (PERTH). Dampier: 160 km SW of Anna Plains, Beauglehole 11317, Aug 1965 (NT, PERTH). Fitzgerald: 14 km N of Napier Range, Symon 10136, May 1975 (BRI, PERTH). Hall: Picaninny Creek Gorge, $15 \mathrm{~km}$ SE of Bungle Bungle Outcamp, Bungle Bungle Range, Blackwell BB 336, June 1985 (NSW, PERTH). Fortescue: 4 km SW of Shay Gap (town), c. 165 km E of Port Hedland, Newbey 10255, July 1984 (PERTH).

4b. C. microcephalus subsp. chersophilus K.L. Wilson, subsp. nov.

A subsp. microcephalo foliis crispatis, plerumque glumis spiculisque longioribus, differt.

TyPe: WeStern Australia: North Kimberley: near the Spillway, Lake Argyle, K.L. Wilson 4890, 26 Apr 1983; holo NSW; iso AD, BRI, CANB, DNA, K, NY, P, PERTH. Figure 15a.

Slender perennial, $25-50 \mathrm{~cm}$ high. Culms usually scabrous at least near apex, 0.5-1.5 $\mathrm{mm}$ diam. Leaves canaliculate or occasionally flat, somewhat curly, not septate-nodulose, shorter than culms, to $2 \mathrm{~mm}$ wide; midrib occasionally obvious abaxially and usually smooth; leaf sheaths not septate-nodulose, salmon-coloured or orange-brown. Inflorescence simple, 0-8 primary branches 2-8 cm long; bracts erect to spreading, 1-3 exceeding the inflorescence, often curly. Spikelets 6-15 in large, sparse clusters of 1-5 cm diam.; spikelets (6)-10-30 mm long, 2.0-3.0 mm wide in side view, (4-)6-32flowered; rachilla not winged; glume spacing 1.2-1.7(-2.1) $\mathrm{mm}$. Glumes very narrowovate to narrow-ovate, acute with straight or slightly excurved mucro (0.1-)0.2-0.4 mm long, (2.0-)2.4-3.6 mm long, 0.3-0.5(-0.7) mm wide, sides 2-3(-4)-nerved. Anthers 0.3$1.1 \mathrm{~mm}$ long excluding appendage $0.2-0.4 \mathrm{~mm}$ long. Nut trigonous, narrow-elliptic, faces flat, red-brown to dark red-brown, tuberculate to slightly elongate-colliculate, shining, $1 / 2-3 / 4$ as long as the glume, $0.3-0.4 \mathrm{~mm}$ diam. Figure $13 \mathrm{~d}-\mathrm{f}$.

Distribution: From the Kimberley region of Western Australia to the Darwin \& Gulf and Barkly Tableland regions of the Northern Territory. Figure 14b. 


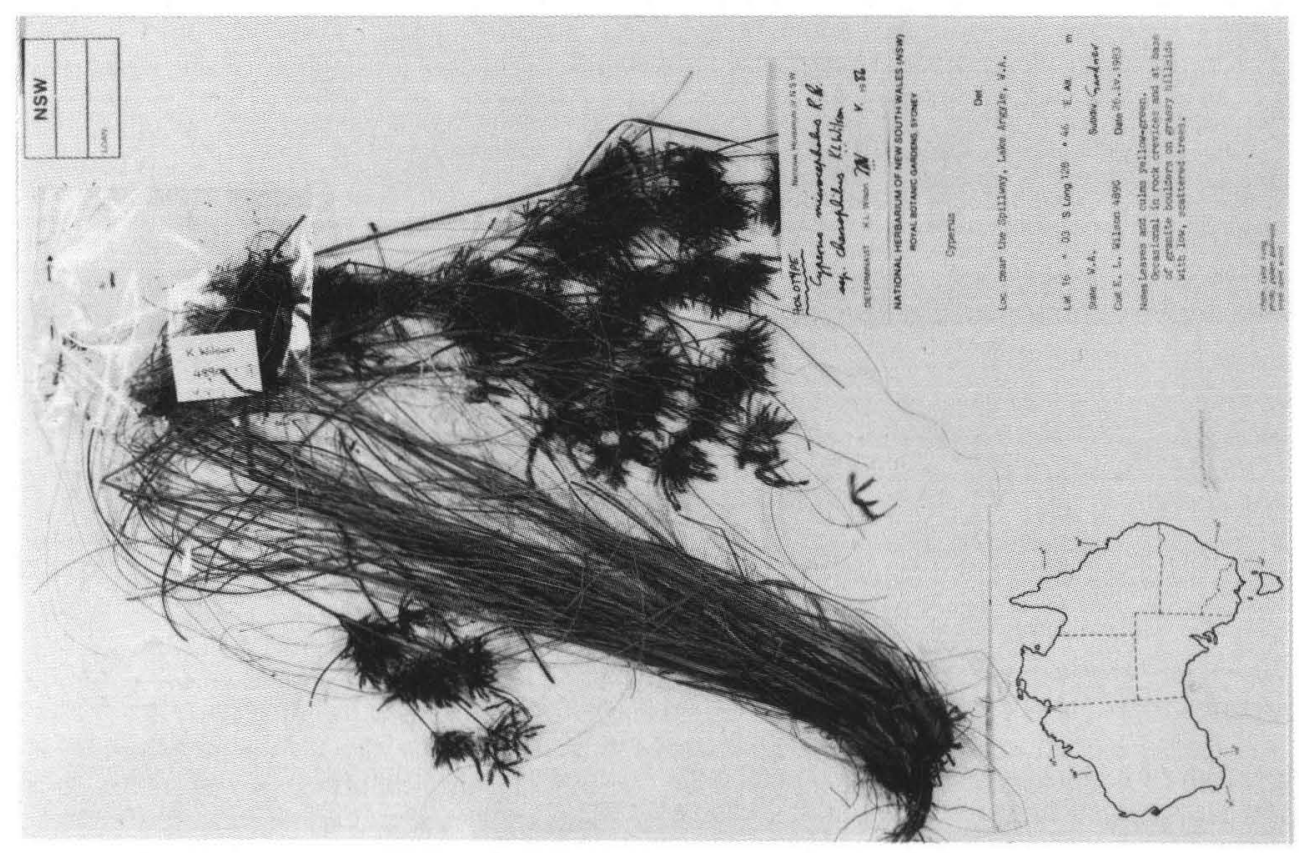

a

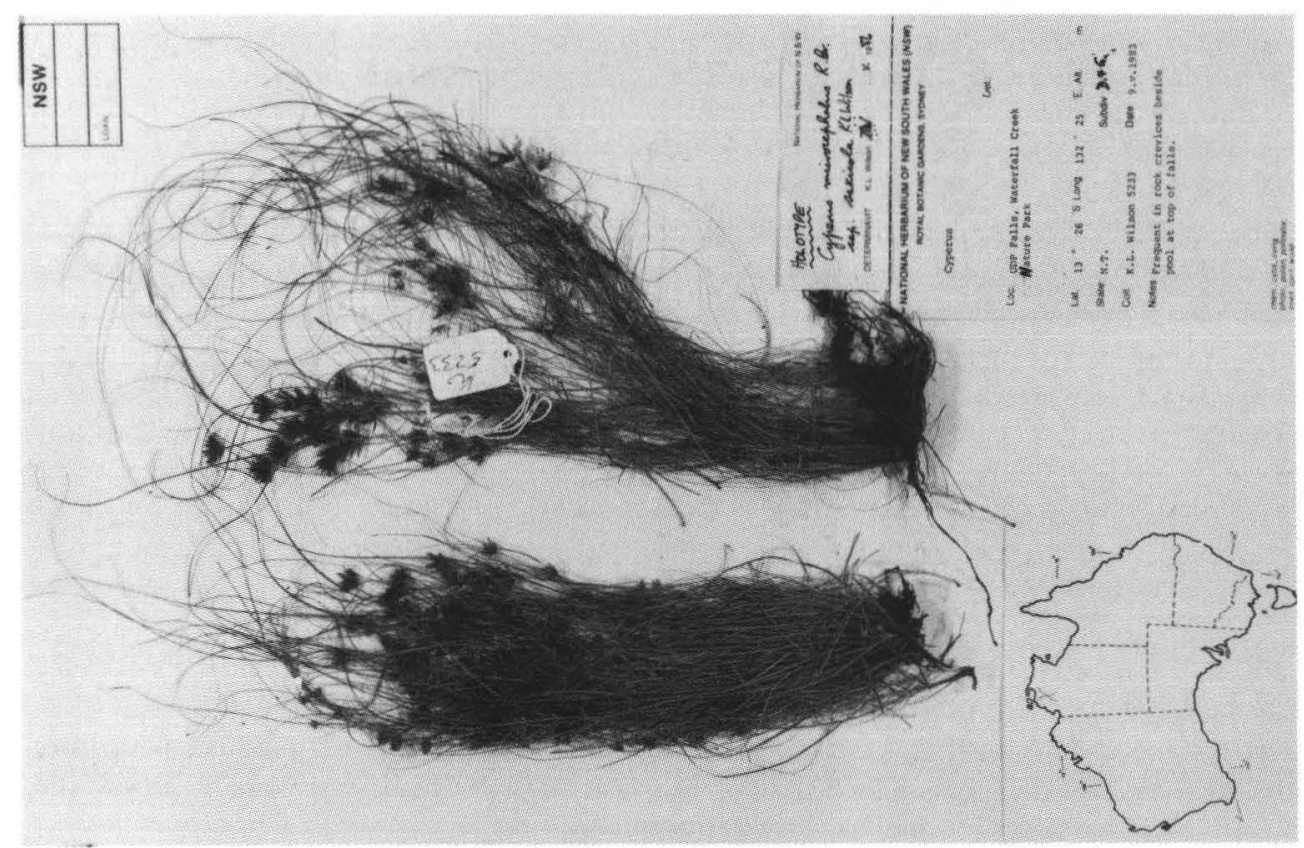

b

Figure 15. Holotype of a, C. microcephalus subsp. chersophilus; b, C. microcephalus subsp. saxicola. 
НАвІтAт: On open hillsides, amongst boulders and hummock grasses or in rock crevices.

The epithet is derived from the Greek chersos, dry land, and phileo, to love, referring to the habitat of the subspecies.

Differs from subspecies microcephalus and saxicola in the long, narrow glumes in the generally long spikelets. Also differs from subsp. microcephalus in the curly, narrow, canaliculate leaves.

SELECTED SPECIMENS (30 examined): NORTHERN TERRITORY: Darwin and Gulf: O.T. Station, Blake 17679, May 1947 (BRI, K, L, MEL, NSW); Nicholson R. area, near Fish R. gorge in China Wall, Kanis 1755, June 1974 (CANB, K, NT). Victoria River: Gardner Range, NW Tanami Desert, Latz 8620, Apr 1981 (NSW, NT); 4 km S Timber Creek Racecourse, Must 1560, July 1979 (NT); 20 miles [32 km] N Victoria R. Downs Station, Perry 2117, June 1949 (BRI, CANB). Barkly Tableland: Newcastle Waters, Latz 5996, May 1975 (BRI, NSW, NT). WESTERN Australia: Gardner: S side of Cockburn Range, c. $6.5 \mathrm{~km} \mathrm{~W}$ of King R., Beauglehole \& Carr 47196, July 1974 (NSW, NT); headwaters Packsaddle Creek, N Carr Boyd Ranges, Hartley 14341, Mar 1978 (CANB, PERTH); Ord R. Dam, Latz 5444, June 1974 (NSW); vicinity of Kimberley Research Station, Mackenzie 690315, 1969 (CANB); Lake Argyll, Must 1276, Sep 1974 (NSW, NT, PERTH); near the Spillway lookout, Lake Argyle, Wilson 4891, Apr 1983 (NSW). Dampier: Windjina Gorge, Napier Range, Beauglehole \& Carr 47686, July 1974 (ACB). Fitzgerald: Lennard R. Gorge, King Leopold Range, Beauglehole \& Carr 47752, July 1974 (NSW, NT); Mabel Downs, Winnama Gorge, Chesterfield 211, May 1984 (NSW ex MEL); Mount Eliza, West Kimberley, Fitzgerald, May 1905 (NSW 153243), Fitzgerald 735, May 1905 (PERTH); c. 17.5 km S of Turkey Creek, Winnama Spring, Willis, May 1984 (NSW 166822 ex MEL). Hall: Halls Creek, Mullumby, May 1972 (PERTH); 18.5 miles [30 km] WSW of Lissadell Station, Perry 2678, Aug 1949 (BRI, CANB).

\section{4c. C. microcephalus subsp. saxicola K.L. Wilson, subsp. nov.}

A subsp. microcephalo foliis crispatis, bracteis involucralibus longis, habitu gracile, nuce triquetro, differt.

TYPE: NORTHERN TERRITORY: Darwin and Gulf: UDP Falls, Waterfall Creek Nature Park, K.L. Wilson 5233, 9 May 1983; holo NSW; iso DNA, K. Figure 15b.

[C. castaneus Willd. form: Hamilton in Ewart \& Davies (1917: 288)]

Slender perennial, $20-40 \mathrm{~cm}$ high. Culms smooth, 0.3-1.0 mm diam. Leaves thickened, canaliculate, somewhat curly, not septate-nodulose, often longer than the short culms, to $1.3 \mathrm{~mm}$ wide; midrib not obvious; leaf sheaths not septate-nodulose, salmoncoloured. Inflorescence small, simple or occasionally small-compound, (2-)4-7(-12) primary branches to $2-5 \mathrm{~cm}$ long; bracts erect, mostly curly towards apex, 2-4 much exceeding the inflorescence (occasionally longer than the culms). Spikelets few in clusters of $0.5-1.2 \mathrm{~cm}$ diam.; spikelets $3-8(-11) \mathrm{mm}$ long, $1.2-2.0 \mathrm{~mm}$ wide in side view, 4-8(-12)-flowered; rachilla not or rarely broadly winged, wings $0.05-0.15 \mathrm{~mm}$ wide; glume spacing $0.8-1.2(-1.5) \mathrm{mm}$. Glumes very narrow-oblong to very narrow-ovate, acute to retuse with straight mucro $0.1-0.3 \mathrm{~mm}$ long, $1.0-2.0 \mathrm{~mm}$ long, $0.2-0.5 \mathrm{~mm}$ wide, sides 1-3-nerved. Anthers $0.3-1.0 \mathrm{~mm}$ long excluding appendage $0.1-0.4 \mathrm{~mm}$ long. Nut triquetrous, very narrow-elliptic to narrow-elliptic, faces flat, dark red-brown to black, tuberculate or shortly elongate-colliculate, glistening, about as long as or exceeding the glume, 0.2-0.5 mm diam. Figure $13 \mathrm{~g}-\mathrm{i}$.

Distribution: From the Kimberley region of Western Australia to the western edge of the Burke region, Queensland. Figure 14c.

HABITAT: In rock crevices on rock outcrops. Specimens growing on rock faces are often of weeping habit.

The epithet is derived from the Latin saxum, a rock, and -cola, a dweller or inhabitant, in reference to the habitat of the subspecies. As with all epithets ending in -cola, this 
should be treated as a noun in apposition, i.e. the ending does not vary with the gender of the associated generic name.

Most specimens from Arnhem Land differ from the rest in having culms much shorter than the involucral bracts, glumes that are usually shorter (1.0-1.4 mm long) and relatively broader $(0.3-0.5 \mathrm{~mm}$ wide) and more elliptical than oblong in side view, and nuts that are usually shorter (1.1-1.5 mm long) and relatively broader $(0.3-0.5 \mathrm{~mm}$ diam.). More typically, the subspecies has culms longer than or equalling the involucral bracts, glumes (1.3-) $1.5-2.0 \mathrm{~mm}$ long and $0.2-0.5 \mathrm{~mm}$ wide, and nuts (1.3-) $1.4-1.8 \mathrm{~mm}$ long and $0.2-0.3(-0.5)$ diam. Further study is needed to determine whether the Arnhem Land material represents a separate taxon or just an ecologically induced extreme.

This subspecies differs from subsp. microcephalus in its curly leaves, slender habit and triquetrous nut with flat faces. It can be found growing near subsp. microcephalus, but usually in different microhabitats. For example, Wilson 5202 (subsp. microcephalus) and 5203 (subsp. saxicola) from Moline Rockhole, Northern Territory: the former subspecies was growing at the base of rock outcrops beside a creek and the latter in shallower soil in rock crevices beside the creek and up the slope.

SeleCted SPECIMENS (75 examined): QueEnsLAND: Burke: Hells Gate near Westmoreland, Carolin 9170, May 1974 (SYD, K), Jacobs 1535, May 1974 (NSW). NORTHERN TERRITORY: Darwin and Gulf: Katherine Gorge, Blake 17209, Oct 1946 (BRI), Jacobs 3755, Apr 1980 (NSW); Cahills Crossing, East Alligator R., Blake 17124, Oct 1946 (BRI); Borroloola, Hill 596, Nov 1911 (MEL, NSW); 24 miles [38 km] N Mainoru, Latz 2734, June 1972 (NSW); Edith Falls, Latz 3102, July 1972 (NSW), Wilson 4962, Apr 1983 (NSW, AD, BRI, CANB, DNA, H, K, L, MEL, P, PERTH, UB); Cox R. Station, Tanumbirini Creek, Latz 7308, July 1977 (NT, BRI, NSW); 4 miles [6 km] NE Mountain Valley HS., Nelson 185, Apr 1962 (NT, CANB, MEL, NSW); 8 km W of Roper Bar, Parker 911, June 1977 (DNA, BRI, CANB, DNA); Robin Falls, Wilson 5026, Apr 1983 (NSW, AD, BRI, NT, P, PERTH); Sculthorpe Pound, Latz 10129, Aug 1985 (NSW); Alligator Yard, c. $20 \mathrm{~km} \mathrm{NW}$ of Bauhinia Downs Station, Leach 565, May 1985 (NSW). Barkly Tableland: $20 \mathrm{~km}$ SSW of Wollogorang Homestead, Latz 11210, Jan 1989 (NSW). WeSTERN AUSTRALIA: Gardner: Mitchell R., Dunlop 5234, Feb 1980 (DNA, NSW); Surveyor Fall near Mitchell R., George 13144, June 1975 (PERTH); Augustus I., Bonaparte Archipelago, P. Wilson 10720, May 1972 (PERTH); Boongaree I., Prince Frederick Harbour, P. Wilson 11337, July 1973 (PERTH). Fitzgerald: Hidden I., Buccaneer Archipelago, Kenneally 8371, 8392, June 1982 (PERTH).

The following specimens are referable to the Arnhem Land 'form':

Mt Brockman, 13 km S of Jabiru East, Site 122, Craven 6492, June 1980 (CANB, DNA, L, NSW); ESE Mudginberry, Dunlop 3306, Feb 1973 (DNA, NT); East Alligator R. (top of sandstone escarpment), Dunlop 3347, Feb 1973 (DNA, NT); Little Nourlangie Rock, Dunlop 4728, Mar 1978 (DNA, NSW, NT), Wilson 5191, May 1983 (NSW, DNA); Arnhem Land, $12^{\circ} 52^{\prime} \mathrm{S} 134^{\circ}$ 32' $\mathrm{E}, \mathrm{Latz}$ 2996, June 1972 (NSW); Nourlangie Rock, Rice 2575, May 1978 (DNA); Koongarra, Rice 3263, Apr 1981 (CANB, NSW); Liverpool R. headquarters, Wightman 1432 \& Craven, Apr 1984 (DNA, BRI, NSW); Bauhinia Downs Station, Wightman 1841 \& Leach, May 1985 (DNA, NSW).

\section{Cyperus crispulus K.L. Wilson, sp. nov.}

C. microcephalo affinis sed nuce nitenti superficiebus convexis, foliis crassis canaliculatisque crispatisque, aculeis marginum foliorum mixtis, differt.

TYPE: NORTHERN TERRITORY: Darwin and Gulf: c. $2 \mathrm{~km} \mathrm{~N}$ of Tanumbirini Waterhole, K.L. Wilson 5303, 12 May 1983; holo NSW; iso DNA, K, PERTH. Figure 16a.

Slender perennial, tufted, $20-40 \mathrm{~cm}$ high, often viscid. Culms terete, smooth, c. $1 \mathrm{~mm}$ diam. Leaves thickened, canaliculate, usually curly towards the apex, not septatenodulose, $\leq$ culms, to $1.2 \mathrm{~mm}$ wide, mid-green; midrib not obvious abaxially; marginal prickles sparse to very sparse, regularly spaced $(0.2-2.0 \mathrm{~mm}$ apart), very short to short, 


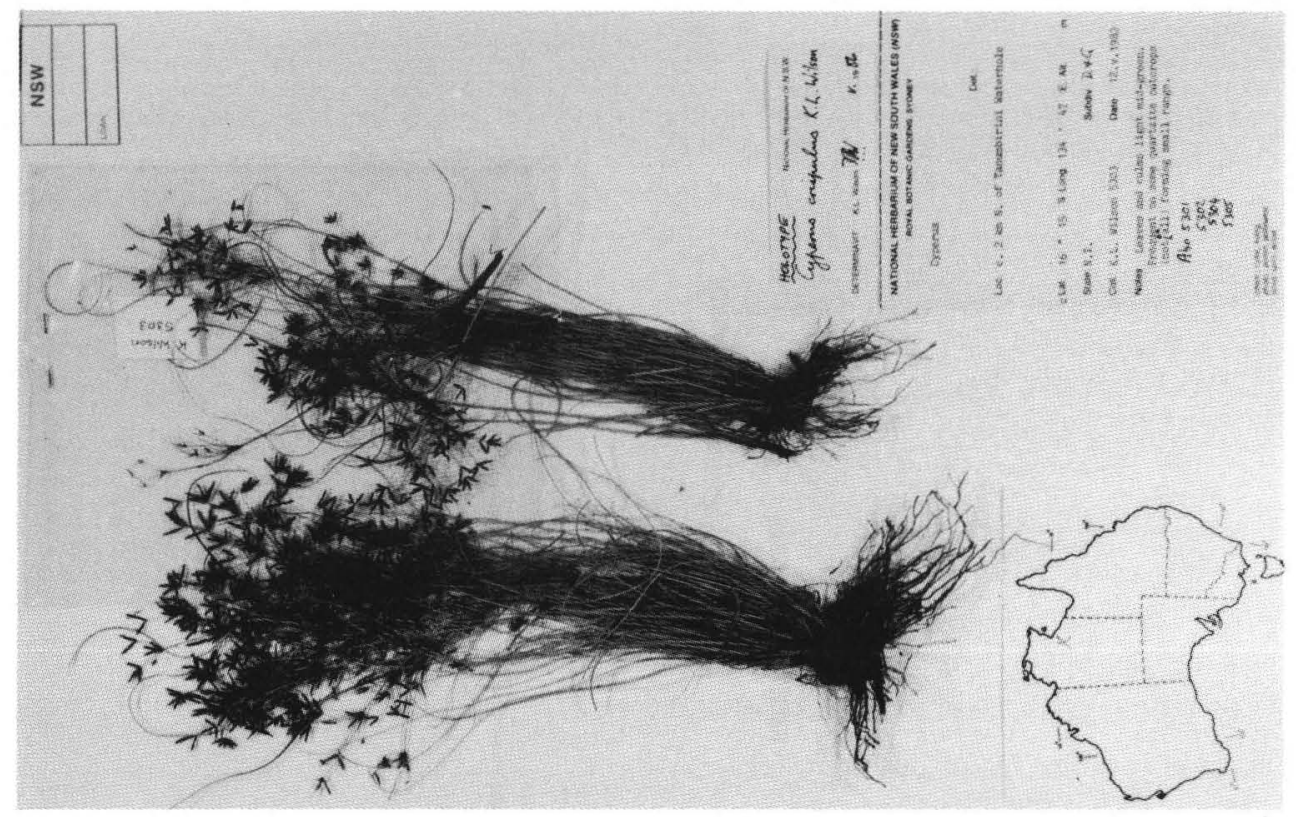

a

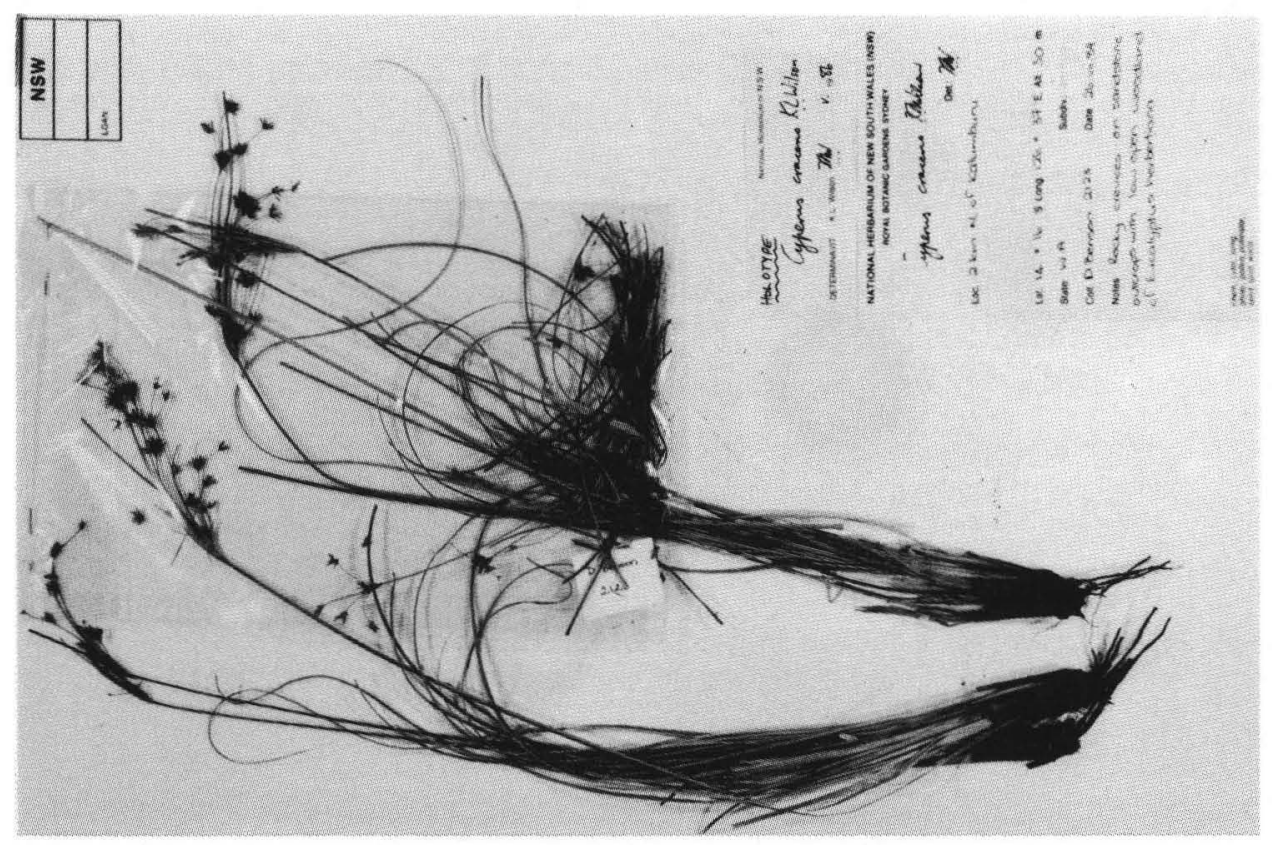

b

Figure 16. Holotype of a, C. crispulus; b, C. cracens. 
no more than $0.05 \mathrm{~mm}$ long, antrorse to erect, aculeate to papillate; leaf sheaths not septate-nodulose, somewhat smooth and shining, pale orange-brown to red-brown. Inflorescence small-compound to decompound, 5-12 primary branches to $8 \mathrm{~cm}$ long; bracts erect, somewhat curly, 1-2 exceeding the inflorescence. Spikelets 3-8 in loose, subdigitate, hemispherical clusters of $0.7-2 \mathrm{~cm}$ diam.; spikelets somewhat compressed, oblong, 4-9(-16) $\mathrm{mm}$ long, 1.0-1.7 $\mathrm{mm}$ wide in side view, 4-12(-18)-flowered, may be viscid; rachilla mostly thickened at maturity $(0.05-0.20 \mathrm{~mm}$ thick), narrowly to broadly winged, wings $0.05-0.10 \mathrm{~mm}$ wide; glume spacing $1.1-1.6(-2.0)$ $\mathrm{mm}$; spikelet with rachilla persistent and glumes falling individually, or units of ultimate branch plus spikelets falling. Glumes elliptic to obovate, acute, with straight mucro $0.1-0.2 \mathrm{~mm}$ long, golden-brown to dark red-brown, with green midrib, 1.2-1.7(2.0) $\mathrm{mm}$ long, $0.4-0.6 \mathrm{~mm}$ wide, sides 3-5-nerved, margins very narrow-membranous towards apex and \pm not inrolled. Anthers $0.5-0.8 \mathrm{~mm}$ long excluding appendage $0.1-$ $0.3 \mathrm{~mm}$ long. Nut trigonous, narrow-obovate to narrow-elliptic with broad-acute apex, faces convex, very dark red-brown to black, tuberculate, shining, 1.2-1.7 mm long, about as long as the glume, $0.3-0.5 \mathrm{~mm}$ diam., falling separately from glume. Figure $13 \mathrm{j}-1$.

Distribution: From the Northern Kimberley of Western Australia to the Darwin \& Gulf region of the Northern Territory. Figure 14d.

HABITAT: In crevices on rocky outcrops.

The epithet is the diminutive of the Latin crispus, curled, referring to the rather curly leaves and bracts.

C. crispulus is related to C. sexflorus and C. microcephalus but differs from both species in its low stature, its slender but thickened and curly canaliculate leaves and bracts without an obvious midrib, and with mixed sparse marginal prickles. It is also distinguished from $C$. microcephalus by its smooth culms, and its shining nut with convex faces.

Specimens eXAMINEd: Northern Territory: Darwin and Gulf: O.T. Station, Blake 17673, May 1947 (BRI, K, NSW); $1 \mathrm{~km} \mathrm{~S}$ of Twin Falls, Site 53, Craven 5806, May 1980 (CANB); $13 \mathrm{~km}$ SSW of Twin Falls, Site 60, Craven 5903, May 1980 (CANB); c. 65 km S of Jabiru, Site 29, Craven \& Whitbread 7895, Mar 1981 (CANB); Deaf Adder Gorge, Dunlop 4441, Feb 1977 (DNA, NSW, NT); Tanumbirini Waterhole, Latz 1406, June 1971 (NSW ex NT); c. 40 km SSW of Nathan River Homestead, Latz 10119, Aug 1985 (NSW ex NT); 150 km W of Borroloola, Rankin 1878, Apr 1979 (CANB); Nabarlek area, Rankin 2062, Apr 1979 (CANB); c. 2 km N of Tanumbirini Waterhole, Wilson 5303, May 1984 (NSW). WeSteRn Australia: Gardner: Gibb R.-Kalumburu Mission road, Rocky Creek, Beauglehole 51849, May 1976 (NT); 2 km N of Kalumburu, Benson 2124, July 1984 (NSW, K, PERTH); West Bay, Napier Broome Bay, Chesterfield 269, May 1984 (NSW ex MEL); Mitchell R., Dunlop 5240, Feb 1980 (NSW); Camp Creek Gauging Station, Mitchell Plateau, Keighery 4752, Apr 1982 (PERTH).

\section{Cyperus sexflorus $R$. Br.}

Brown (1810: 215); Poiret (1817: 187); Sprengel (1824: 227); Kunth (1837: 111); Steudel (1854: 53); Domin (1915: 432), p.p.; Kern (1974: 661). C. sporobolus R. Br. var. sexflorus (R. Br.) Benth. ex Kükenthal (1935-36: 457), p.p.

TYPE: Carpentaria, R. Brown (Bennett 5903); lecto BM (here designated); isolecto BRI (fragm.), K.

Slender perennial, tufted with slender bulbous base, $55-75 \mathrm{~cm}$ high, not viscid. Culms terete to trigonous, smooth (rarely scabrous at very apex), 1-2 $\mathrm{mm}$ diam. Leaves flat to canaliculate, not septate-nodulose, usually shorter than the culms, to $3.7 \mathrm{~mm}$ wide, mid-green to dark yellow-green; midrib usually obvious abaxially, smooth; marginal 
prickles sparse to dense, regularly spaced $(0.1-0.6 \mathrm{~mm}$ apart), short, $0.05-0.10 \mathrm{~mm}$ long, antrorse, aculeate; leaf sheaths septate-nodulose, smooth and \pm shining, chestnutbrown to pale red-brown. Inflorescence compound, relatively slender, 5-12 primary branches to $7.5 \mathrm{~cm}$ long; bracts \pm erect, $0-2$ exceeding the inflorescence. Spikelets few, 3-14 in loose, shortly spicate to subdigitate, hemispherical clusters of $(0.5-) 0.7-3 \mathrm{~cm}$ diam.; spikelets compressed, \pm oblong, 4-9(-18) $\mathrm{mm}$ long, 1.5-2.5 $\mathrm{mm}$ wide in side view, 4-8(-18)-flowered; rachilla not or occasionally slightly thickened (to $0.15 \mathrm{~mm}$ thick), narrowly or rarely broadly winged, wings $0.05-0.10 \mathrm{~mm}$ wide; glume spacing $1.2-1.5(-1.7) \mathrm{mm}$; spikelet with rachilla persistent and glumes falling individually, or units of ultimate branch plus spikelets falling. Glumes ovate to elliptic, acute to obtuse, with straight mucro $0.1-0.2 \mathrm{~mm}$ long, stramineous to golden-brown with occasional red-brown blotches, with green midrib, 1.6-2.1 $\mathrm{mm}$ long, $0.6-0.7 \mathrm{~mm}$ wide, sides 3-5-nerved, margins narrow-membranous and not inrolled. Anthers $0.4-0.8 \mathrm{~mm}$ long excluding appendage $0.2-0.5 \mathrm{~mm}$ long. Nut trigonous, narrow-obovate to narrow-elliptic with broad-acute apex, faces concave to flat, pale brown to nearly black, colliculate to foveate, shining, $1.8-2.1 \mathrm{~mm}$ long, $\geq$ glume, $0.5-0.7 \mathrm{~mm}$ diam., falling separately from glume. Figure $13 \mathrm{~m}-\mathrm{o}$.

DistriBUtion: From the north-eastern Kimberley of Western Australia to the western end of the Burke District of Queensland. Figure 14e.

HABITAT: Sandy soils; generally in open woodland below rocky outcrops or occasionally on hillsides.

One of only three species in section Pinnati with markedly bulbous culm-bases. It differs from C. sporobolus and C. orgadophilus (which have similarly bulbous bases and occur in similar habitats) in its bigger, compound inflorescence with few spikelets per cluster, its regularly antrorsely aculeate leaf margins, its glumes which are straight or excurved along the midrib as seen in outline (more or less incurved in C. sporobolus and $C$. orgadophilus), and its nut, which generally slightly exceeds the glume.

SPecimens eXamined: QueEnsLand: Burke: Adels Grove, via Camooweal, De Lestang 338, Mar 1947 (BRI); near junction of Lawn Hill Creek and Colless Creek, Taylor 270, Aug 1981 (BRI). NORTHERN TERRITORY: Darwin and Gulf: about E of Mataranka, on Elsey Station, Blake 17534 Apr 1947 (BRI, CANB, K, NSW); McArthur R. area, near Caranbirini Waterhole, Craven 3405, Jan 1976 (CANB); c. $65 \mathrm{~km}$ S of Jabiru, Site 29, Craven $\mathcal{E}$ Whitbread 7894, Mar 1981 (CANB); Cox R. Station, Latz 7859, June 1977 (NT, NSW); Edith Falls, Wilson 4963, Apr 1983 (NSW, DNA); c. 2 km N of Tanumbirini Waterhole, Wilson 5304, May 1983 (NSW, AD, BRI, DNA); Caranbirini Waterhole, c. $32 \mathrm{~km}$ SW of Borroloola, Wilson 5340, 5341, May 1983 (NSW, DNA); $25 \mathrm{~km}$ WSW of Borroloola on Cape Crawford road, Wilson 5377, May 1983 (NSW, BRI, DNA). Victoria River: Keep River National Park, Dunlop 5731, Feb 1981 (DNA, NSW); 12 miles [19 km] SSE of Willeroo Station, Perry 2045, June 1949 (CANB, BRI, K, NT). WESTERN Australia: Gardner: Kimberley Research Station, Langfield 31, Jan 1949 (CANB, PERTH); Anjo Peninsula separating Napier Broome Bay and Vansittart Bay, Willis, May 1984 (NSW ex MEL); Hidden Valley, $2.5 \mathrm{~km}$ NNE of Kununurra, Wilson 4794, Apr 1983 (NSW, AD, DNA, K, PERTH).

\section{Cyperus portae-tartari K.L. Wilson}

Wilson (1980: 460, pl. 26)

TYPE: QuEENSLAND: Burke: Hells Gate, S.W.L. Jacobs 1527, 9 May 1974; holo NSW; iso K.

Short but robust annual or perennial with relatively large inflorescence, tufted, shallow-rooted, 35-60(-90) $\mathrm{cm}$ high, not viscid. Culms trigonous, often scabrous for most of length, 1.2-4 mm diam. Leaves flat to carinate, septate-nodulose, $\geq$ culms, to $8.5 \mathrm{~mm}$ wide, dark yellow-green; midrib obvious abaxially, scabrous; marginal prickles dense to occasionally sparse, mostly regularly spaced $(0.1-0.6(-0.9) \mathrm{mm}$ apart), short, $0.05-$ 
$0.10 \mathrm{~mm}$ long, finely antrorse, aculeate; leaf sheaths usually not septate-nodulose, finely striate and slightly shining, pinkish to chestnut-brown or stramineous with dark red-brown blotches. Inflorescence compound to decompound (to four orders of branching), numerous primary branches (13->17) to $16 \mathrm{~cm}$ long; bracts spreading, 38 exceeding the inflorescence. Spikelets 1-7 in subdigitate, loose hemispherical to globose clusters of $0.5-1.3 \mathrm{~cm}$ diam.; spikelets compressed, oblong, 3-8 mm long, 1.7-2.5 $\mathrm{mm}$ wide in side view, 3-10(-20)-flowered; rachilla not thickened, broadly winged, wings $0.10-0.15 \mathrm{~mm}$ wide; glume spacing $1.0-1.3(-1.5) \mathrm{mm}$; glumes falling individually or spikelet falling as a unit, or ultimate branch plus spikelets falling as a unit. Glumes broad-elliptic to broad-ovate, broad-acute with relatively stout, straight or excurved mucro $0.2-0.3(-0.5) \mathrm{mm}$ long, red-brown with green midrib (often antrorsely aculeate), $1.3-1.9 \mathrm{~mm}$ long, $0.5-0.7 \mathrm{~mm}$ wide, sides 2-4-nerved, margins narrowmembranous towards the apex and not inrolled. Anthers $0.3-0.8 \mathrm{~mm}$ long excluding appendage $0.2-0.3 \mathrm{~mm}$ long. Nut \pm trigonous, obovate to broad-obovate, with broadacute apex, faces somewhat concave or flat, black, tuberculate, glistening, 1.1-1.4 mm long, $7 / 8$ as long as to exceeding the body of the glume, $0.5-0.7 \mathrm{~mm}$ diam., falling separately from the glume. Figure $17 \mathrm{a}-\mathrm{c}$.
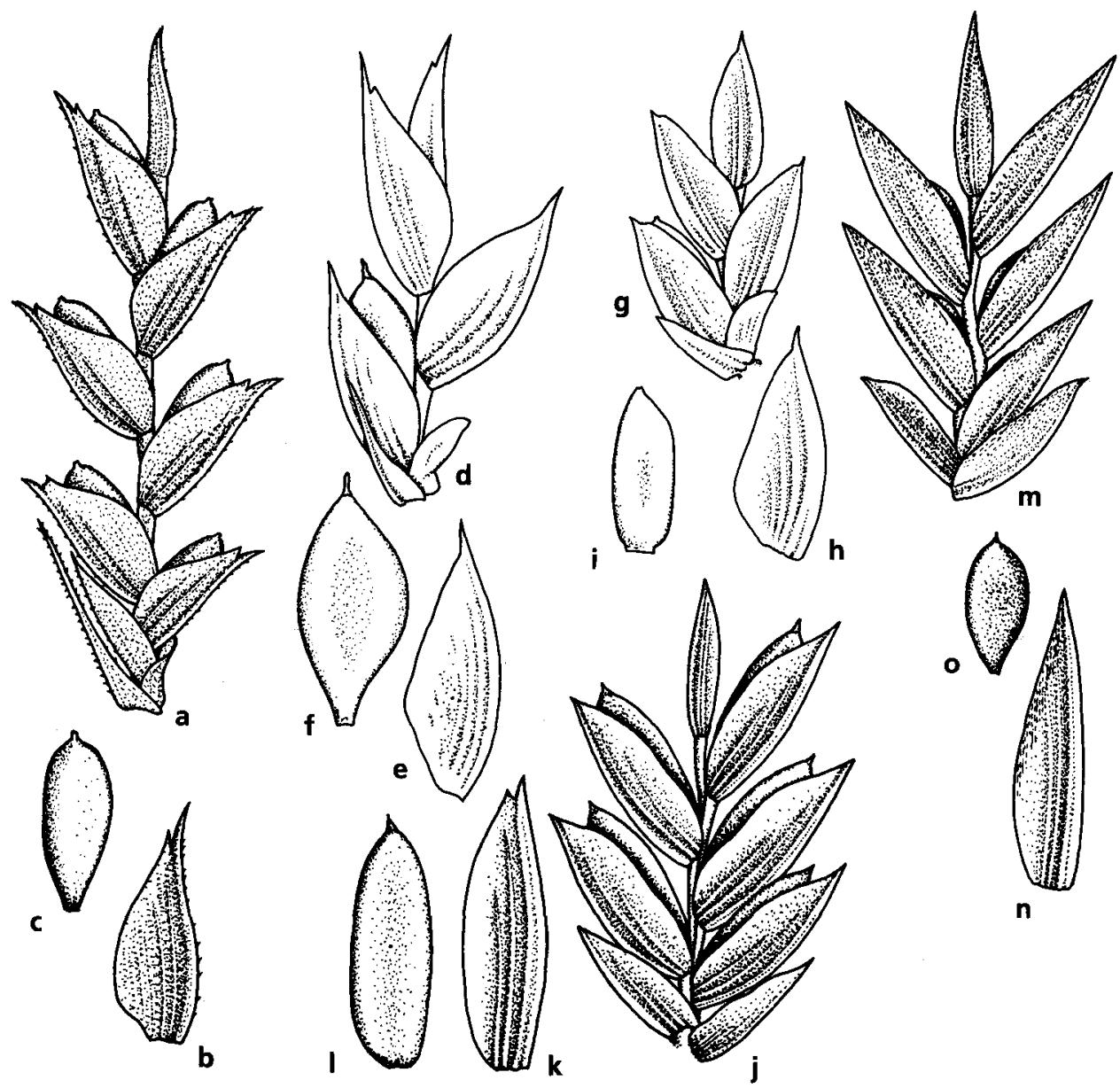

Figure 17. Spikelet details. C. portae-tartari: a, spikelet; b, glume; c, nut. C. cracens: d, spikelet; e, glume; $\mathbf{f}$, nut. C. sporobolus: $\mathbf{g}$, spikelet; $\mathbf{h}$, glume; $\mathbf{i}$, nut. C. orgadophilus: $\mathbf{j}$, spikelet; $\mathbf{k}$, glume; $\mathbf{1}$, nut. C. blakeanus: m, spikelet; n, glume; o, nut. a-c from Dunlop 4455; d-f Beauglehole 51856; g-i Wilson 5204; j-1 Adams 1400; m-o Maconochie 781. a, d, g, j, m X 11; b, c, e, f, h, i, k, l, n, o X 14. 
DistRIBUTION: In the Darwin \& Gulf region of the Northern Territory and Burke region of north-western Queensland. Figure 14f.

HABITAT: Sandy soils; damp sites amongst boulders or along streams.

Distinctive in this group by the often scabrous midrib of the glume (occasionally scabrous in C. cracens, and rarely so in a few others), but similar in this character to species in the American section Glutinosi (C. elegans, C. rubiginosus, C. trachysanthos). This character state is also seen in $C$. renschii Boeck. and C. laxus Poir.

The species is similar in habit to $C$. microcephalus but glume and nut shape are very different. Its leaves are the same shade of green as those of $C$. astartodes, with which it sometimes grows. The specimen Craven 5854 is unusual in having thickened rachillas.

It superficially resembles C. laxus Poir. (C. diffusus Vahl) in habit and glumes, but the two species are taxonomically distant: $C$. laxus, also found in northern Australia, is a non-Kranz $\left(\mathrm{C}_{3}\right.$ photosynthesis) species with soft-textured leaves with distant nerves and nearly smooth margins, smooth triquetrous culms and a broad yellow-brown wing to the rachilla.

SELECTED SPECIMENS (29 examined): QueENSLAND: Burke: Jacobs 1527 (K, NSW). NORTHERN TERRITORY: Darwin and Gulf: McArthur R. area, near Glyde R., Craven 3499, Jan 1976 (CANB, BRI, L, NT); $9.5 \mathrm{~km}$ S of Twin Falls, Craven 5884, May 1980 (CANB); Mt Brockman, Site 122, Craven 6506, June 1980 (CANB, BRI, DNA, G, NSW); Katherine Gorge National Park, above Lily Pond, Craven 6715, Apr 1981 (CANB, DNA); $17.5 \mathrm{~km}$ SSE of Koongarra, Craven 6265, 6274, June 1980 (CANB); Little Nourlangie Rock, Dunlop 4727, Mar 1978 (DNA, CANB), Wilson 5190, May 1983 (NSW); Magela Creek, Dunlop 3366, Feb 1973 (DNA, BRI, CANB, K, NSW, PERTH); Deaf Adder Gorge, Dunlop 4455, Feb 1977 (DNA, NSW, NT); top of Jim Jim Falls, Dunlop 5650, Jan 1980 (DNA, BRI, NSW); $6 \mathrm{~km}$ S Mt Gilruth, Arnhem Land, Jones 1548, Mar 1984 (DNA, BRI, NSW, PERTH); 70 miles [113 km] E of Oenpelli mission, Latz 3064, June 1972 (NSW); c. $40 \mathrm{~km}$ SSW of Nathan River Homestead, Latz 10122, Aug 1985 (NSW ex NT); Radon Creek, c. 12 km S Jabiru, Latz 7682, June 1978 (NSW ex NT); Nabarlek area, Rankin 2057, Apr 1979 (NT, CANB); Kakadu National Park, c. $5 \mathrm{~km}$ S of Cahills Crossing, Thompson 304, Apr 1983 (CANB); Edith Falls, Wilson 4966, Apr 1983 (NSW).

\section{Cyperus cracens K.L. Wilson, sp. nov.}

A C. sporobolo habitu inflorescentiaque pergracili, basibus non bulbosis, nuce glumisque saepe latioribus, differt.

TYPE: WeStern Australia: North Kimberley: $2 \mathrm{~km}$ N of Kalumburu, D.H. Benson 2123, 26 July 1984; holo NSW; iso PERTH. Figure 16b.

[Cyperus sporobolus auct. non R. Br.: Fitzgerald (1918: 117), p.p. (Fitzgerald 1025, Isdell River)]

Slender perennial, tufted, $35-80 \mathrm{~cm}$ high, with spikelets occasionally viscid. Culms trigonous to terete, smooth or scabrous, $0.7-1.5 \mathrm{~mm}$ diam. Leaves canaliculate, usually not septate-nodulose, c. $2 / 3$ as long as culms, to $2.5 \mathrm{~mm}$ wide; midrib not obvious abaxially; marginal prickles sparse, regularly spaced (0.4-1.6 mm apart), short, $0.05-0.10 \mathrm{~mm}$ long, antrorse, aculeate; leaf sheaths not septate-nodulose, \pm smooth and shining, stramineous above, red-brown to purple-red below. Inflorescence small-compound to compound, slender, 5-11 primary branches to $10 \mathrm{~cm}$ long; bracts erect, 1-2 exceeding the inflorescence. Spikelets 4-9 in small, dense, subdigitate, hemispherical to subglobose clusters of $0.3-1 \mathrm{~cm}$ diam.; spikelets compressed, oblong, 3-6 mm long, 1.5-3 mm wide in side view, 1-5-flowered, occasionally viscid; rachilla not thickened, broadly winged; wings $0.15-0.25 \mathrm{~mm}$ wide; glume spacing (1.3-)1.5-1.8 mm; spikelet with 
rachilla persistent and glumes falling individually, or ultimate branch plus spikelets falling as a unit. Glumes broad-elliptic to broad-ovate, broad-acute, with excurved mucro $0.2-0.6 \mathrm{~mm}$ long, stramineous to occasionally dark red-brown, with green and sometimes scabrous midrib, convex in outline, (1.4-)1.9-2.8 $\mathrm{mm}$ long, 0.8-1.1 mm wide, sides (2-)3-5-nerved, margins broad white- to yellow-membranous (reddish in Dunlop 5269) and not inrolled. Anthers $0.7-1.1 \mathrm{~mm}$ long excluding appendage $0.1-0.5 \mathrm{~mm}$ long. $\mathrm{Nut}$ trigonous, obovate to broad-obovate with apex broad-acute, faces concave, black, tuberculate to colliculate, glistening or shining, 1.2-1.9 mm long, $\geq$ body of glume, $0.8-1.3 \mathrm{~mm}$ diam., falling separately from glume. Figure $17 \mathrm{~d}-\mathrm{f}$.

DistRibution: Northern Kimberley region of Western Australia and Darwin \& Gulf region in the Northern Territory. Figure $18 a$.

HABITAT: Sandy soils; along creeks on levees or occasionally in rock crevices in dry creek beds.

The epithet refers to the species' slender habit; from the Latin cracens, slender or graceful.

Dunlop 5269 differs from other specimens in being very slender, with glumes that are red and short (but still very broad: c. $1.4 \mathrm{~mm}$ long, 0.8-0.9 mm wide) and have a short mucro 0.1-0.2 mm long.

C. cracens has been found growing near $C$. astartodes, but is readily distinguished from that species by its broad glumes and nuts and its slender, somewhat weeping habit. C. cracens differs from $C$. sporobolus and C. orgadophilus in its very slender, tufted habit, its slender inflorescence (which is small-compound and is subtended by 1-2 erect bracts), its broader glumes and nut, and often longer glume mucro. C. portae-tartari differs from $C$. cracens in its larger, more branched inflorescence, densely and finely aculeate leaf and bract margins, and smaller nut and glumes (which are less strongly incurved than in C. cracens).

SPECIMENS EXAMINED: NoRTHERN TeRrITORY: Darwin and Gulf: Jim Jim Creek, $3.5 \mathrm{~km}$ ESE of Jim Jim Falls, Site 55, Craven 5826, May 1980 (CANB, DNA, MEL, NSW); 16 km SE of Koongarra (Site 90), Craven 6254, June 1980 (DNA, L); $17.5 \mathrm{~km}$ SE of Koongarra, Site 92, Craven 6263, June 1980 (CANB). WeSTERN Australia: Gardner: Kimberleys, Gibb R.-Kalumburu Mission road, Rocky Creek, Beauglehole 51856, May 1976 (NT); Rocky Creek, c. $60 \mathrm{~km} \mathrm{~N}$ of Drysdale River, Benson 2088b, July 1984 (NSW); Anjo Peninsula, Chesterfield 406, May 1984 (NSW ex MEL); Mitchell R., Dunlop 5269, Feb 1980 (NSW); Isdell R., near Mt Barnett HS., Fitzgerald 1025, May 1905 (PERTH, BRI); Blyxa Creek, Prince Regent R. Reserve, George 12515, Aug 1974 (PERTH). Fitzgerald: Augustus I., Bonaparte Archipelago, $P$. Wilson, May 1972 (PERTH).

\section{Cyperus sporobolus $R$. Br.}

Brown (1810: 215); Poiret (1817: 187), as 'spherobolos'; Sprengel (1824: 226); Kunth (1837: 111); Steudel (1854: 53); Bentham (1878: 281) p.p.; Bailey (1902: 1746) p.p.; Domin (1915: 432); Ewart \& Davies (1917: 56) p.p.; Kükenthal (1935-36: 457) p.p.

TYPE: NORTHERn Territory: Carpentaria island ' $\mathrm{s}$ ' [Morgans Island, Blue Mud Bay], $R$. Brown (Bennett 5904); lecto BM (here designated); isolecto BM, BRI (fragm.), DBN, E, $\mathrm{K}$. There is a second sheet labelled Bennett 5904 in $\mathrm{K}$ but with the locality given as 'East Coast'. This is a mixture of C. fulvus (left-hand specimen) and C. sporobolus (right-hand specimen).

Slender perennial, with definitely bulbous base, tufted or very shortly rhizomatous, 30$80 \mathrm{~cm}$ high, not viscid. Culms obscurely trigonous to terete, smooth, 1-2 mm diam. Leaves occasionally somewhat thickened, canaliculate, flat or carinate, occasionally septate-nodulose, from half as long as to longer than culms, to 2.5(-5) mm wide, yellow- 
green to mid-green; midrib often obvious abaxially, usually smooth; marginal prickles very sparse to dense, usually regularly spaced $(0.2-1.1 \mathrm{~mm}$ apart), short, $0.05 \mathrm{~mm}$ long, antrorse to erect, aculeate; leaf sheaths not septate-nodulose, not shining, orange-brown. Inflorescence simple or small-compound, 3-8 primary branches to $7 \mathrm{~cm}$ long; bracts erect or spreading, may be somewhat curly, 2-5 exceeding the inflorescence; small leafy bracts obvious at the base of individual spikelet clusters. Spikelets numerous in dense,

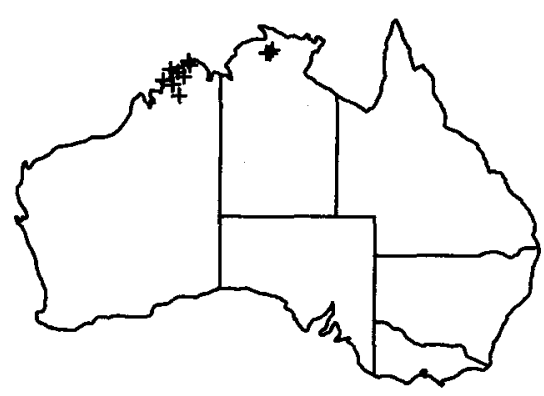

a

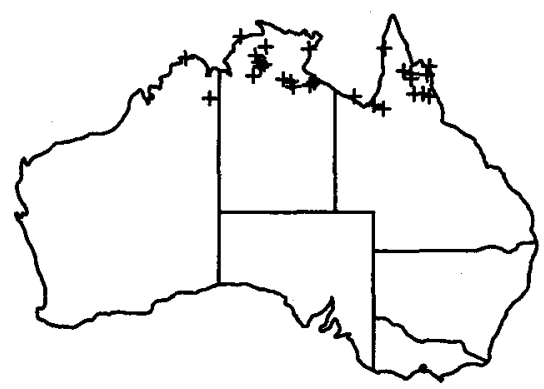

c 2

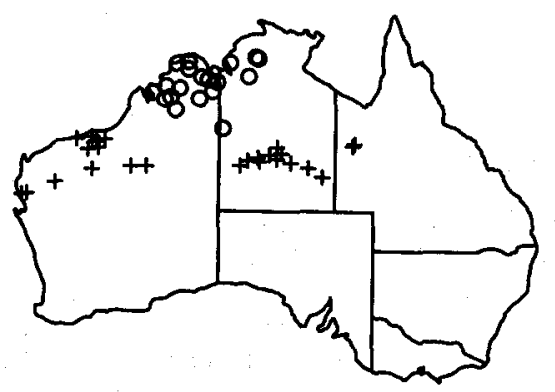

e

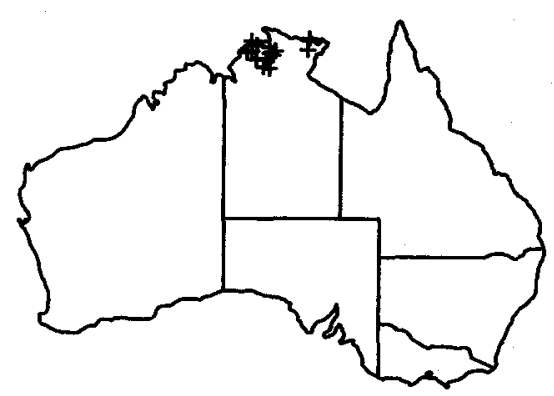

b

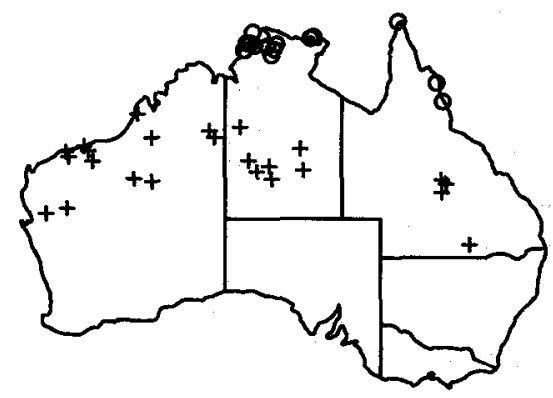

d 0

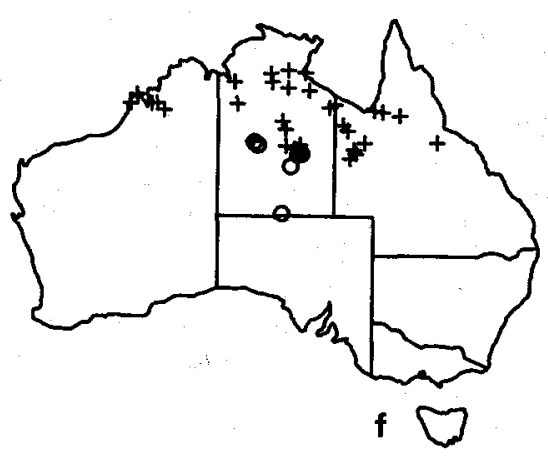

Figure 18. Distribution of: a, C. cracens; b, C. sporobolus; c, C. orgadophilus; d, C. blakeanus (crosses) and $C$. angustatus (open circles; New Guinea occurrence not mapped); e, C. ixiocarpus (crosses) and $C$. viscidulus (open circles); $f, C$. carinatus (crosses) and possible hybrid $C$. carinatus $X$ C. centralis (open circles). 
subdigitate, hemispherical or ovoid clusters of $0.5-1.5 \mathrm{~cm}$ diam.; spikelets \pm compressed, shortly oblong, 3-6(-15) $\mathrm{mm}$ long, 1.5-3.0 $\mathrm{mm}$ wide in side view, 2-5(-14)flowered; rachilla mostly thickened (to $0.25 \mathrm{~mm}$ thick), broadly winged, wings $0.1-0.2$ mm wide; glume spacing 1.5-2.1 mm; spikelets with rachilla persistent and glumes falling individually. Glumes broad-ovate to ovate, acute, with incurved to excurved mucro $0.2-0.5 \mathrm{~mm}$ long, golden-brown to pale red-brown, with green midrib strongly incurved or straight in outline, $2.0-2.6 \mathrm{~mm}$ long, $0.6-1.0 \mathrm{~mm}$ wide, sides $3-5$-nerved, margins usually very narrow-membranous and not inrolled. Anthers $0.5-1.0 \mathrm{~mm}$ long excluding appendage $0.2-0.3 \mathrm{~mm}$ long. $N u t$ trigonous, obovate to narrow-elliptic with broad-acute to acute apex, faces concave or flat, very dark red-brown to black, tuberculate, glistening or shining, $1.7-2.3 \mathrm{~mm}$ long, as long as to slightly exceeding glume, 0.5-1.0 mm diam., falling separately from glume. Figure $17 \mathrm{~g}-\mathrm{i}$.

Distribution: Only in the Darwin \& Gulf region of the Northern Territory. Figure 18b.

HABITAT: Sandy or lateritic soils; in open savanna woodland, usually associated with rock outcrops, or in soil pockets on rocky hillsides.

This species, C. orgadophilus and C. sexflorus (q.v.) are the only three species in this Section with strongly bulbous bases. Occasionally, C. blakeanus, C. centralis and C. fulvus have somewhat bulbous bases.

C. sporobolus is close to C. orgadophilus but differs in its thickened and broadly winged rachilla, its greater glume spacing, its glumes (differently shaped, more prominently nerved, and with a longer mucro), its nut (colour, shape and size), and its \pm regularly aculeate leaf margins. In addition, the inflorescence of $C$. sporobolus has a different appearance because of the prominence of the short leaf-like bracts at the base of each spikelet cluster. Spikelets are generally short but occasionally are much longer (e.g. Dunlop 3046, which has a mixture of long and short spikelets). The two species have slightly overlapping distributions in the Top End of the Northern Territory, but they have not been found growing together at any site. Indeed, their habitat preferences seem different. C. sporobolus is associated with rocky outcrops in woodland, while C. orgadophilus grows in savanna woodland too, but associated with low-lying areas rather than rocky outcrops.

Ryves (1976) lists C. sporobolus as a wool-alien at Blackmoor Fruit Farm, N Hants., England, but the specimen (n.v.) is unlikely to be this tropical species. It may be C. fulvus or C. rigidellus: both are species that are found in wool-producing areas.

SElected SPECIMENS (25 examined): NorTHERN TERRITORY: Darwin and Gulf: $16 \mathrm{~km}$ SE of Koongarra, Site 90, Craven 6254, June 1980 (CANB, BRI, MEL, NSW); near Bills Pool, Blake 17018, Sep 1946 (BRI); $26 \mathrm{~km} \mathrm{~S}$ of Cooinda, Site 106, Craven 6370, June 1980 (CANB); Katherine Gorge National Park, above Lily Pond, Craven 6722, Apr 1981 (CANB, DNA, L); c. 4 km E of Jabiru, Site 20, Craven \& Whitbread 7880, Mar 1981 (CANB, DNA); c. $40 \mathrm{~km}$ NW of Jabiru, Site 15, Craven \& Whitbread 7897, Mar 1981 (CANB); Gunn Point, Darwin, Dunlop 3046, May 1973 (DNA, BRI, NT), McKean 1330, Dec 1973 (NT, BRI, CANB, K, L, NSW); Hayes Creek, Dunlop 4096, Jan 1976 (DNA, BRI, CANB, NSW, NT); Twin Falls, Dunlop \& Taylor 6222, Mar 1982 (DNA, CANB, NSW, NT); Arnhem Land, Latz 2955, June 1972 (DNA, BRI, CANB, NT); Elcho Island, Latz 6130, July 1975 (DNA, BRI, NT); Lake Bennett road, 2 km E of Stuart Highway, Wilson 5047, Apr 1983 (NSW); Moline Rockhole, 9 km NE of Mary R., Wilson 5204, May 1983 (NSW); Christmas Creek rock paintings, Wilson 5238, May 1983 (NSW); 0.5 miles [1 km] NW of Edith R. siding, I. Wilson 218, Jan 1965 (CANB, BRI, NT). 
10. Cyperus orgadophilus K.L. Wilson, sp. nov.

A C. sporobolo rhachilla nec alata nec crassa, intervallo inter glumas adjacenti $0.7-1.5$ $\mathrm{mm}$, glumis ellipticis mucrone breviore, nuce pallidiore, aculeis marginum foliorum mixtis, differt.

TYPE: NORTHERN TERRITORY: Victoria River: $15 \mathrm{~km} \mathrm{~S}$ of Victoria Highway on Delamere road, K. Wilson 4924 \& R. Barker, 27 Apr 1983; holo NSW; iso BRI, DNA, K, P. Figure 19a.

[Cyperus angustatus var.: Boeckeler (1874: 367); Schultz 291 is cited but presumably this is an error for Schultz $791(\mathrm{~K})$ ]

[Cyperus carinatus auct. non R. Br.: Kükenthal (1935-36: 455), p.p. Mariscus carinatus auct. non (R. Br.) C.B. Clarke: Domin (1915: 441), p.p. (Henne, Sweers Island)]

[C. fulvus auct. non R. Br.: Domin (1915: 443), p.p. min.; Kükenthal (1935-36: 456), p.p. min. (MacGillivray, Cape York)]

[C. holoschoenus auct. non R. Br.: Bentham (1878: 273), p.p. min.; Kükenthal (1935-36: 481), p.p. min. Mariscus holoschoenus auct. non (R. Br.) C.B. Clarke: Domin (1915: 441), p.p. min. (Mueller, Upper Victoria River)]

[C. sexflorus auct. non R. Br.: Domin (1915: 432), p.p. (Schultz 791, Port Darwin)]

[C. sporobolus auct. non R. Br.: Bentham (1878: 281) p.p.; Bailey (1902: 1746) p.p.; Ewart \& Davies (1917: 56) p.p.; Kükenthal (1935-36: 457) p.p.; Blake in Specht \& Mountford (1958: 319)]

Slender perennial, with definitely bulbous base, tufted or very shortly rhizomatous, $30-80 \mathrm{~cm}$ high, not viscid. Culms obscurely trigonous to terete, smooth, 1-2 mm diam. Leaves canaliculate, mostly septate-nodulose, from half as long as to longer than culms, to $2.5(-5) \mathrm{mm}$ wide, yellow-green to mid-green; midrib not obvious abaxially; marginal prickles very sparse to dense, irregularly spaced (0.2-3.0 mm apart), short, 0.05$0.10 \mathrm{~mm}$ long, antrorse to retrorse or flabellate, papillate or aculeate; leaf sheaths not septate-nodulose, not shining, orange-brown. Inflorescence simple or small-compound, 3-8 primary branches to $7 \mathrm{~cm}$ long; bracts erect or spreading, may be somewhat curly, (1-)2-4 exceeding the inflorescence. Spikelets numerous in dense, subdigitate, hemispherical or ovoid clusters of $0.5-1.5 \mathrm{~cm}$ diam.; spikelets \pm compressed, shortly oblong, 3-6.5 mm long, 1.5-2.5 mm wide in side view, (1-)3-8-flowered; rachilla not thickened, mostly narrowly winged, wings $0.05-0.10 \mathrm{~mm}$ wide; glume spacing $0.7-1.5 \mathrm{~mm}$; spikelets with rachilla persistent and glumes falling individually. Glumes elliptic, occasionally narrower, acute to broad-acute, with straight or incurved mucro $<0.1-0.2 \mathrm{~mm}$ long, stramineous to pale red-brown, with green midrib usually incurved in outline, $1.5-2.5 \mathrm{~mm}$ long, $0.3-0.8 \mathrm{~mm}$ wide, sides $3-5$-nerved, margins usually very narrow-membranous and not inrolled. Anthers $0.5-1.0 \mathrm{~mm}$ long excluding appendage $<0.1-0.2 \mathrm{~mm}$ long. Nut trigonous, narrow-elliptic to narrowobovate with acute apex, faces flat, yellow-brown to pale red-brown, tuberculate or small-colliculate, shining, 1.5-2.2 mm long, slightly shorter than to equalling glume, $0.5-0.7 \mathrm{~mm}$ diam., falling separately from glume. Figure $17 \mathrm{j}-1$.

Distribution: From the far eastern Kimberley of Western Australia to Cook District, Queensland. The species seems not to extend to the northern part of the Top End of the Northern Territory (the northernmost known localities are near Pine Creek and an apparent outlier near Jim Jim Creek). An old specimen labelled Port Darwin (Schultz $791 ; \mathrm{K})$ is probably mislabelled. Figure $18 \mathrm{c}$. 


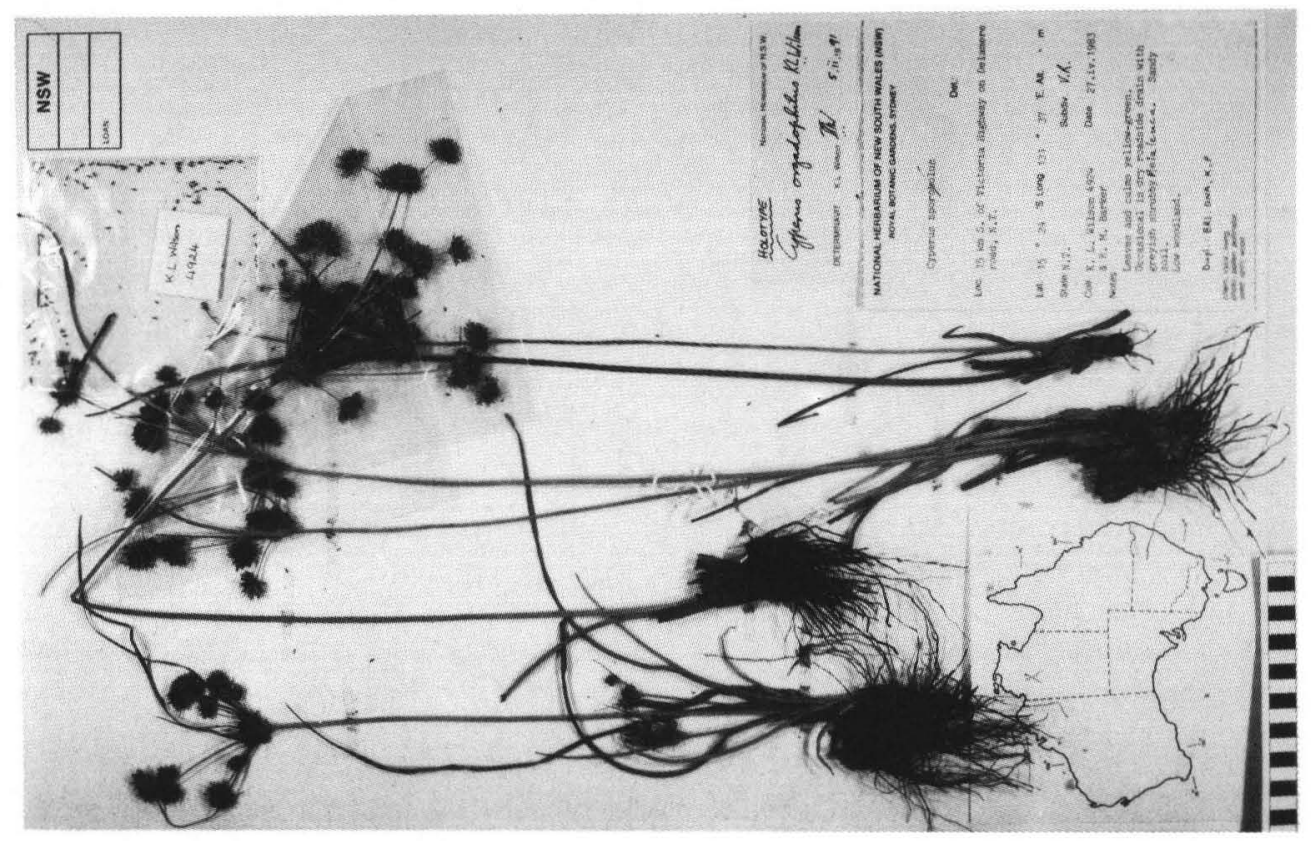

a

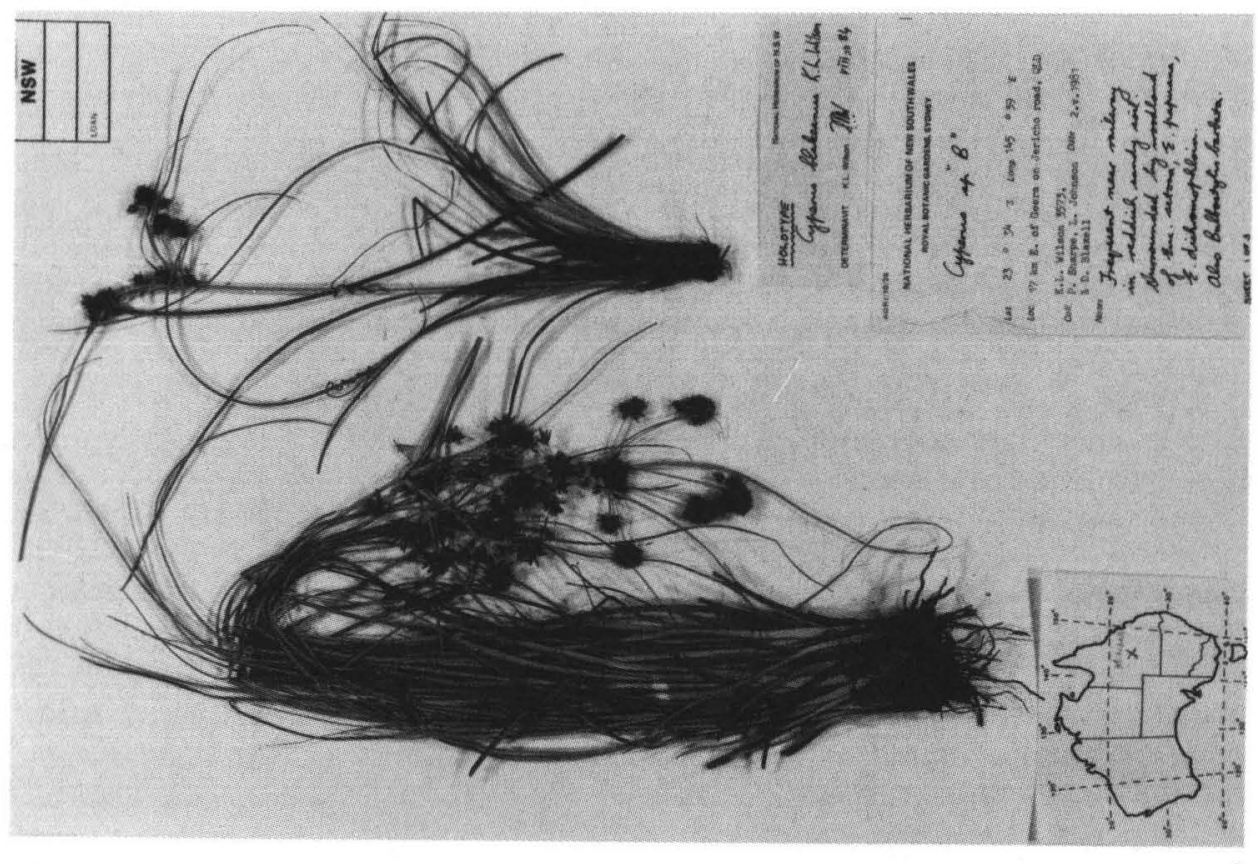

Figure 19. Holotype of a, C. orgadophilus; b, C. blakeanus. 
HABITAT: Sandy or lateritic soils; in open savanna woodland, often in more low-lying places.

The epithet is derived from Greek orgas, orgados, a partly wooded field or a wellwatered, fertile tract of land, and phileo, to love, referring to the savanna habitat of the subspecies.

Specimens from the eastern end of the subspecies' range have larger glumes than those from the western part of its range (NW Queensland to the Kimberley): glumes $2.0-2.6 \mathrm{~mm}$ long, $0.5-0.8 \mathrm{~mm}$ wide in side view versus $1.5-2.0 \mathrm{~mm}$ long, $0.3-0.6 \mathrm{~mm}$ wide. There do not seem to be any other significant differences.

The species is close to $C$. sporobolus (q.v.), which also has a strongly bulbous base. It differs from that species in its thin rachilla (usually with narrow wings), its lesser glume spacing, its elliptic glumes with shorter mucro, its paler nut, and its irregularly papillate or aculeate leaf margins.

SELECTED SPECIMENS (37 examined): QuEENSLAND: Cook: near Mareeba, Blake 13425, Mar 1938 (BRI, K, MEL, NSW); near Cooktown, Endeavour R., Blake 20253, Feb 1958 (BRI); 6 km from Watson R. Crossing on Aurukun-Merluna road, Clarkson 4068, Dec 1981 (CANB, NSW ex BRI); Lizard Island, Specht \& Specht LI 273, 275, Dec 1974 (BRI); Kalinga Station (Hann Telegraph Office), Staples IBS 2245, Jan 1976 (NSW). Burke: $60 \mathrm{~km}$ SE of Normanton and $8 \mathrm{~km} \mathrm{~N}$ of Croydon road, Beeston 92, June 1972 (BRI, NT); Normanton, Blake 8955, May 1935 (BRI); Sweers Island, Henne, - (BRI 177987, K, MEL). NoRTHERN TERRITORY: Darwin and Gulf: N of Nutwood Downs HS. on lateritic tableland, Blake 17581, May 1947 (BRI); c. $50 \mathrm{~km}$ SSW of Jabiru, Site 3, Craven $\mathcal{E}$ Whitbread 7901, Mar 1981 (CANB); Pine Creek, Dunlop 4176, Apr 1977 (DNA, NSW); Arnold River shed, Latz 7144, June 1977 (NSW); King R., 25 miles [40 km] S of Katherine, McKee 8453, Feb 1961 (BRI, K, NSW, NT); c. $2 \mathrm{~km}$ N of Tanumbirini Waterhole, Wilson 5305, May 1983 (NSW); $25 \mathrm{~km}$ WSW of Borroloola on Cape Crawford road, Wilson 5380, May 1983 (NSW). Victoria River: Victoria R., Gregory National Park, Clark \& Wightman 365, Feb 1986 (DNA). Western Australia: Gardner: Anjo Peninsula, E of Vansittart Bay, Willis, May 1984 (NSW ex MEL). Fitzgerald: c. $17.5 \mathrm{~km} \mathrm{~S}$ of Turkey Creek, Winnama Spring, Willis, May 1984 (NSW ex MEL). Hall: Mabel Downs, Winnama Gorge, Turkey Creek, Chesterfield 208, May 1984 (NSW).

\section{Cyperus blakeanus K.L. Wilson, sp. nov.}

C. sporobolo affinis sed basibus non nisi subbulbosis, antheris longioribus, glumis anguste ovatis apice longe acuto, differt.

TYPE: QuEENSLAND: Mitchell: $17 \mathrm{~km}$ E of Geera on Jericho road, K.L. Wilson 3573, $P$. Sharpe, L. Johnson and D. Blaxell, 2 May 1981; holo NSW; iso BRI, K, NT. Figure 19b.

[C. sp. aff. holoschoenus: Wilson (1981a: 508, Figure 638J)]

More or less slender perennial, tufted, often with a thickened and somewhat bulbous base, $25-55 \mathrm{~cm}$ high, not viscid. Culms trigonous with very rounded angles or terete in big specimens, smooth or slightly scabrous, $1.0-3 \mathrm{~mm}$ diam. Leaves somewhat thickened, canaliculate, occasionally septate-nodulose, $2 / 3$ as long as to slightly exceeding culms, to $3 \mathrm{~mm}$ wide; midrib rarely obvious abaxially and may then be scabrous; leaf margins sparse to very sparse, irregularly spaced (0.1-2.0 mm apart), short, c. $0.05 \mathrm{~mm}$ long, erect to antrorse or flabellate, papillate to aculeate; leaf sheaths not septate-nodulose, smooth, occasionally shining, salmon-pink to pale brown with brown-hyaline margins. Inflorescence simple to small-compound, dense or \pm open; primary branches $5-9(-11)$, to $6.5 \mathrm{~cm}$ long, occasionally reflexed; bracts erect or spreading, 2-5(-7) exceeding the inflorescence. Spikelets numerous in shortly spicate to subdigitate, hemispherical or ovoid clusters of $0.5-1.5 \mathrm{~cm}$ diam. (occasionally the clusters coalesce to give a head-like appearance to the inflorescence). Spikelets compressed when young, compressed or sometimes spirodistichous (and then terete) 
when mature, oblong to ovate, 3-5(-9) $\mathrm{mm}$ long, 2.0-3.0(-3.5) $\mathrm{mm}$ wide in side view, 2-8(-12)-flowered; rachilla rarely thickened at maturity (to $0.1 \mathrm{~mm}$ thick), usually narrowly winged, wings $0.05-0.10 \mathrm{~mm}$ wide; glume spacing c. $0.6 \mathrm{~mm}$ in spirodistichous spikelets, $0.9-1.3(-1.5) \mathrm{mm}$ in distichous spikelets; spikelet with rachilla persistent and glumes falling individually. Glumes ovate to elliptic, long-acute with straight mucro $\leq 0.1(-0.2) \mathrm{mm}$ long, stramineous with red-brown blotches or evenly red-brown (rarely somewhat golden) with broad green midrib, 2.0-3.0 mm long, 0.5-1.0 mm wide, sides 2-4-nerved (nerves usually close to midrib), margins not inrolled but spreading and not membranous or very narrow-membranous. Anthers $1.2-2.0 \mathrm{~mm}$ long excluding appendage $0.1-0.3 \mathrm{~mm}$ long. $\mathrm{Nut}$ trigonous, narrow-obovate or occasionally shorter and obovate with broad-acute apex, faces concave to flat, golden-brown to dark red-brown to nearly black, smooth and reticulate-areolate, shining, 1.2-2.0 mm long, $1 / 2-7 / 8$ as long as glume, $0.5-0.8 \mathrm{~mm}$ diam., falling separately from glume. Figure $17 \mathrm{~m}-\mathrm{o}$.

Distribution: From the Pilbara and Dampier regions of Western Australia to Central Australia (Central North and Central South), with isolated occurrences in central and southwestern Queensland (Mitchell and Warrego Districts). Figure 18d. Its distribution parallels that of the grass Triodia pungens (Burbidge 1953), except that the latter is also known from the Mt Isa area.

HABITAT: Sandy or loam soils, in open woodland or shrubland, commonly with Triodia pungens, in run-on areas between stable sand-dunes.

The epithet commemorates Dr Stanley Thatcher Blake (1911-1973) of Brisbane, who contributed so greatly to the taxonomic understanding of Australasian Cyperaceae, including this group.

This species differs from all other arid-zone species in the following combination of characters: short culms often with somewhat bulbous bases, small inflorescence with very dense small clusters of spikelets, and mixed prickles on the leaf margins. Its spikelets are mostly laterally compressed but are sometimes spirodistichous (Snow 1955), apparently due to crowding in the small compact spikelet clusters. Glumes are generally brightly coloured at first but fade considerably with age. One specimen (Wilson 3573) has the lowest inflorescence bract and branch separated by about $2 \mathrm{~cm}$ from the rest of the inflorescence.

Despite my tentative assignment in the 'Flora of Central Australia', this species is more closely related to $C$. sporobolus and C. orgadophilus than to C. holoschoenus. It differs from the former two species in its only slightly bulbous bases, longer anthers and narrow-ovate glumes with long-acute apex. From C. sporobolus it further differs in the marginal prickles, the narrowly winged rachilla, the lesser glume spacing, generally shorter glume mucro and the lack of obvious involucral bracts at the base of each spikelet cluster. From $C$. orgadophilus it also differs in the often larger glumes.

Domin (1915: 444) mentions a specimen he had collected 'auf den Sandhügeln der Dividing Range östlich von Jericho'. He referred the specimen to $C$. fulvus but it could be $C$. blakeanus. I have not seen the specimen.

Selected SPECIMENS (32 examined): QueENSLAND: Mitchell: $55 \mathrm{~km}$ E of Aramac on Strasburg road, Beeston 1276, July 1975 (BRI); Yalleroi, Clemens, Apr 1946 (BRI 198859); c. $14 \mathrm{~km}$ E of Geera on Jericho road, Wilson et al. 3570, May 1981 (NSW, BRI, K, NT, NY, P, PERTH). Warrego: Gilruth Plains, Clarke 53, June 1949 (CANB). NORTHERN TERRITORY: Victoria River: Winnecke Creek, Latz 3981, July 1973 (NT, CANB, NSW). Central North: Red Bank Bore, Coniston Station, Latz 1213, Jan 1971 (NT, NSW); Kurundi Station, Latz 2200, Feb 1972 (NT, AD, BRI, NSW); Macdonald Downs, Latz 5786, Oct 1974 (NT, BRI, K, NSW); Napperby Station, Latz 5931, May 1975 (NT, NSW, PERTH); c. 9 miles [14 km] NE of Pats Swamp, Mongrel Downs, Maconochie \& Parker 1027, May 1970 (NT, AD, BRI, NSW, PERTH); between Mt Davidson and Refuge Basin, Parker 208, May 
1970 (NT, BRI, L, NSW, PERTH). Central South: 0.5 miles [1 km] E of Ewalinga Rockhole, Petermann Range, Maconochie 781, Sep 1969 (NT, AD, BRI, NSW, PERTH). WESTERn Australia: Dampier: Willie Creek crossing on Beagle Bay road, Foulkes 99, Jan 1985 (PERTH). Mueller: just W of Wolf Creek Crater, George 15308, Apr 1979 (PERTH, CANB, NT); 33 miles [53 km] S Sturt HS., Latz 4034 (NT, NSW). Canning: N of Dragon Tree Soak, Great Sandy Desert, George 14757, Aug 1977 (PERTH). Fortescue: between Port Hedland and Mundabullangana Station, George 3346, Feb 1962 (PERTH, BRI). Keartland: Little Sandy Desert, Mitchell 918, 937, May 1979 (NT). Ashburton: $20 \mathrm{~km}$ S of Landor HS., P. Wilson 8492, Mar 1969 (PERTH). Carnarvon: Towrana Station, Cranfield 2108, - (PERTH).

12. Cyperus angustatus $R . B r$.

Brown (1810: 214); Sprengel (1824: 221); Kunth (1837: 111); Steudel (1854: 53); Boeckeler (1874: 366), as 'angustatis'; F. Mueller (1875: 54); Bentham (1878: 282), p.p.; Bailey (1902: 1746), p.p.; Ewart \& Davies (1917: 55); Kükenthal (1936: 452), p.p.; Kern (1963: 27; 1974: 638). Mariscus angustatus (R. Br.) C.B. Clarke (1908: 19); Domin (1915: 444), p.p.

Type: Northern Territory: North Coast, R. Brown (Bennett 5909); holo BM.

[C. fulvus auct. non R. Br: Mueller (1874: 268), p.p. min. (Schultz 259, Port Darwin)]

Slender perennial, rhizomatous, $40-100 \mathrm{~cm}$ high, not viscid. Culms obscurely trigonous to \pm terete, smooth or rarely scabrous near the apex, 0.9-1.7(-3) mm diam. Leaves slender, flat, folded to canaliculate with age, not septate-nodulose, about same length as culms, to $3.5 \mathrm{~mm}$ wide; midrib not obvious; marginal prickles sparse (may be nearly absent throughout length), irregularly spaced (0.1-0.9 mm apart), short to long, 0.05-0.15 mm long, antrorse, aculeate; leaf sheaths not septate-nodulose, not shining or smooth, stramineous to red-brown at base, margins pale membranous. Inflorescence simple or small-compound, very open, 4-11 primary branches to $11(-20) \mathrm{cm}$ long; bracts erect and spreading, 1-2 exceeding inflorescence. Spikelets few (3-12) in loose, subdigitate, hemispherical clusters of $1-3.5 \mathrm{~cm}$ diam.; spikelets compressed, oblong, 7-28 mm long, 1.5-2.5 mm wide in side view, 6-28-flowered; rachilla not thickened, usually broadly winged, wings $0.1-0.15 \mathrm{~mm}$ wide; glume spacing $1.3-1.8 \mathrm{~mm}$; spikelet with rachilla persistent and glumes falling individually. Glumes narrowelliptic to very narrow-ovate, acute with straight mucro $0.1-0.2 \mathrm{~mm}$ long, stramineous to red-brown with narrow green midrib, $1.6-2.3 \mathrm{~mm}$ long, $0.5 \mathrm{~mm}$ wide, sides 24-nerved; margins narrow-membranous and not inrolled. Anthers $0.3-0.8 \mathrm{~mm}$ including appendage $\leq 0.1 \mathrm{~mm}$ long. $N u$ t trigonous to nearly terete, narrow-elliptic to narrow-obovate with acute apex, faces flat, pale brown to grey, smooth and reticulate-areolate, shining, $1.5-2.1 \mathrm{~mm}$ long, equalling or slightly exceeding the glume, $0.5-0.7 \mathrm{~mm}$ diam., falling separately from the glume. Figure $20 \mathrm{a}-\mathrm{c}$.

Distribution: Tropical coast and adjoining islands from Darwin, Northern Territory, to the eastern coast of Queensland. Also south-eastern Irian Jaya, in New Guinea. Figure 18d.

HABITAT: Alluvial soils; generally seasonally wet sites, often in fringing woodland at edges of floodplains, swamps or lagoons.

C. angustatus is distinctive in this group of species by its slender habit and rhizome. Occasionally it grows larger and produces big inflorescences with primary branches to $20 \mathrm{~cm}$ long (e.g. Lazarides \& Adams 274, Wilson 5090), but then its parts remain slender and the inflorescences are open and delicate in aspect. It has been confused at times with C. fucosus (q.v.).

Specimens collected by Birch from Bowen/Barcoo Downs (e.g. BRI 199601, MEL 92163) and cited as $C$. angustatus by Bentham, Bailey and Kükenthal, are actually C. bifax 
C.B. Clarke. Both 'Bowen Downs' and 'Barcoo Downs' appear on labels of specimens with Birch as collector: the two place-names seem to be synonymous. According to Kükenthal, Domin (1915) included specimens of C. subulatus (e.g. Dietrich 625, Port Mackay (L!)) in his concept of C. angustatus.
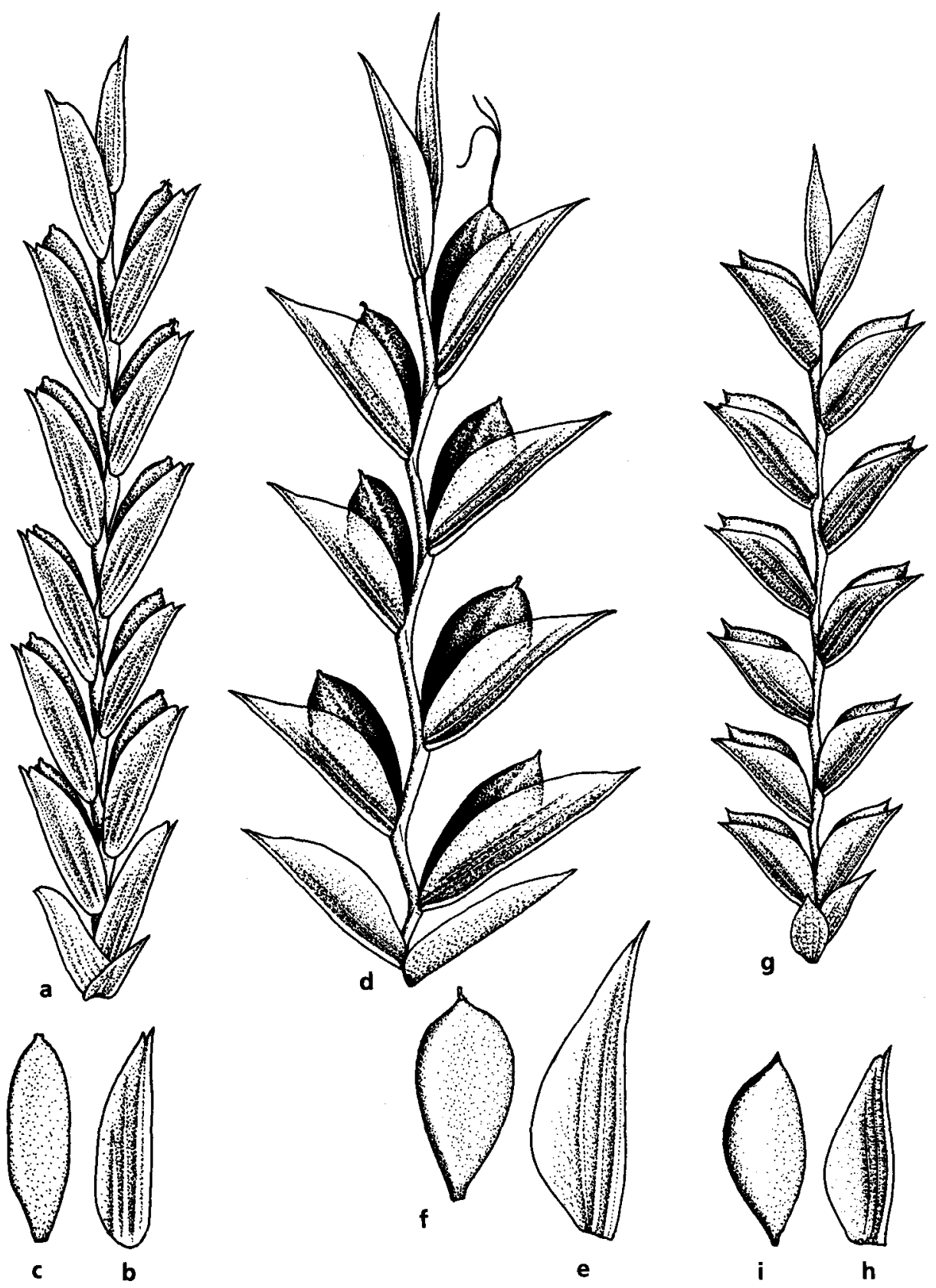

Figure 20. Spikelet details. C. angustatus: a, spikelet; b, glume; c, nut. C. ixiocarpus: d, spikelet; e, glume; f, nut. . C. viscidulus: $\mathbf{g}$, spikelet; $\mathbf{h}$, glume; $\mathbf{i}$, nut. a-c from Latz 3651; $\mathbf{d}-\mathbf{f}$ Chippendale 2078; g-i Beauglehole 47242. a, d, g X 11; b, c, e, f, h, i X 14. 
SPECIMENS EXAMINED: QuEENSLAND: Cook: Cairns, Blake 9352, June 1935 (BRI), Blake 23261, May 1970 (BRI, NSW); Lockerbie, 10 miles [16 km] WSW of Somerset, Brass 18608, May 1948 (CANB). NORTHERN TERRrTORY: Darwin and Gulf: Elcho I., Latz 6247, July 1975 (DNA, BRI, NT); Radon Creek, Mt Brockman, Dunlop 5438, Apr 1980 (NSW, READING); Darwin, Holmes Jungle, Latz 3651, Apr 1973 (NSW); McMinns Lagoon, 17 miles [27 km] ESE of Darwin, Lazarides $\mathcal{E}$ Adams 274, Mar 1965 (CANB); Ritjirriur Swamp, Elcho I., Latz 6134, July 1975 (NT); Wurrpan, Elcho I., Latz 6218, July 1975 (NT); Leichhardt Springs, Rice 2691, June 1978 (DNA); Port Darwin, Schultz 259, Feb 1870 (B, BRI, K, MEL); Mardlow, Melville 1., Stocker 282 \& Fox, Apr 1967 (BRI); Appletree Point, Kapalga, Taylor 350, Apr 1981 (BRI), Taylor 391, May 1981 (BRI); East Alligator R., c. 4 km N of Cahills Crossing, Waterhouse 9763, Apr 1980 (NSW, UNSW); Fogg Dam, Wilson 5090, May 1983 (NSW, DNA, H, K, P, PERTH, UB); Little Nourlangie Rock, Kakadu National Park, Wilson 5189, May 1983 (NSW, DNA, K, P, PERTH). New GUINEA Irian Jaya: Koerik [Kurik], Noordpolder [near Merauke], Hoogerwerf 192, Mar 1962 (L, BRI).

\section{Cyperus ixiocarpus F. Muell.}

Mueller (1886: 55), preprint of (1887: 55); Domin (1915: 430); Blake (1947a: 35), p.p. max.; Wilson (1980: 462, pl. 27, figs. a, b); Wilson (1981a: 506, Figure 638C).

TYPE: WESTERN AUSTRALIA: between the Fortescue and Gascoyne Rivers, H.S. King, 1885; lecto MEL (Blake 1947a). Blake stated that Mueller only cited one specimen but he did, in fact, cite two: the King collection and a Forrest collection from the Gascoyne River. Blake actually cited the latter as well in his paper but indicated only the former as type. Depending on one's interpretation of the International Code, Blake's publication may be regarded as inadequate for lectotypification; if so, then this present paper should be regarded as the place of lectotypification.

[C. dactylotes auct. non Bentham: Ewart \& Davies (1917: 55), p.p. (Hill 318)]

[C. fulvus auct. non R. Br.: Fitzgerald (1918: 117, p.p. (Polak, Gascoyne River)]

Robust perennial, tufted, deep-rooted, $50-80 \mathrm{~cm}$ high, very viscid in the inflorescence (apparently produced in the spikelets). Culms terete, smooth, 2.5-3.5 mm diam. Leaves thick-textured, canaliculate, septate-nodulose, $2 / 3$ as long as culms, to $5 \mathrm{~mm}$ wide, tending to curve when long, pale blue-green; midrib usually not obvious abaxially, or occasionally obvious and scabrous towards the apex; marginal prickles very sparse to sparse, irregularly spaced $(0.6-3.5 \mathrm{~mm}$ apart), short, $0.05-0.1 \mathrm{~mm}$ long, somewhat antrorse, aculeate; leaf sheaths not septate-nodulose, striate, not shining, stramineous with dark red-brown blotches. Inflorescence compound or rarely decompound, 9-18 primary branches to $12 \mathrm{~cm}$ long; bracts \pm erect, septate-nodulose, tending to curve when long, 2-3 exceeding the inflorescence. Spikelets few in loose, subdigitate, hemispherical clusters $1.5-3.5 \mathrm{~cm}$ diam.; spikelets compressed, oblong, $10-35 \mathrm{~mm}$ long, $3.0-5.0 \mathrm{~mm}$ wide in side view, 6-28-flowered, very viscid; rachilla not thickened, not to broadly winged, wings to $0.15 \mathrm{~m}$ wide; glume spacing $2.2-2.7 \mathrm{~mm}$; spikelet with rachilla persistent and glumes falling individually, or unit of spikelets plus ultimate branch falling. Glumes elliptic to ovate, acute with straight mucro $0.2-0.5 \mathrm{~mm}$ long, stramineous to golden-brown with green midrib, $2.5-3.0 \mathrm{~mm}$ long, $0.6-0.8 \mathrm{~mm}$ wide, sides 2-3-nerved, margins not inrolled and very narrow-membranous. Anthers 0.7-1.3 $\mathrm{mm}$ long excluding appendage $\leq 0.1 \mathrm{~mm}$ long. Nut trigonous, broad-obovate to elliptic with broad-acute apex, faces concave, dark brown to black, small-colliculate to tuberculate, shining, usually viscid, 1.6-2.1 mm long, $2 / 3-3 / 4$ as long as glume, 1.0 $1.1 \mathrm{~mm}$ diam., broader than glume but held in place by viscidity and falling with glume. Figure $20 \mathrm{~d}-\mathrm{f}$.

Distribution: From the Pilbara region of Western Australia through Central Australia (Central North and South) to Mt Isa, Queensland. Figure 18e. 
HABITAT: Apparently restricted to sandy banks or sand drifts in stream-beds (where moisture is often close to the surface).

This species is distinctive because of its large floral parts and its extremely viscid spikelets. Immature spikelets are not viscid. Blake (1947a) created a new section Ixiocarpi (in subgenus Cyperus) for this 'attractive and distinctive' species, having dismissed the possibility of a close relationship with $C$. elegans L. He regarded the morphological differences between $C$. ixiocarpus and $C$. dactylotes as being too great for them to be included in the same Section (a point of view with which I disagree). He suggested an affinity with 'C. zollingeri' (= C. tenuiculmis Boeckeler), but then (rightly) gave a long list of morphological characters by which it differs from that species. The leaf anatomy of that species also differs: as seen in cross-section, it has a single row of vascular bundles, not A-type anatomy as in C. ixiocarpus.

It can be distinguished from $C$. viscidulus, another species in which the glumes are often viscid, by its stiffer inflorescence branches, greater glume spacing, its larger glumes, anthers and nuts, its narrower glume margins, and the prickles on its leaf margins.

It occasionally grows with $C$. betchei subsp. commiscens, $C$. dactylotes and $C$. cunninghamii subsp. cheradicus. Its broader nut and spikelets, its strong viscidity, and the irregular prickles on the leaf margins distinguish it from all these taxa. C. cunninghamii subsp. cheradicus is also occasionally viscid, but differs in being more slender with longer glumes.

A note on one specimen, Green NT 54058 from 'Utopia' Station, says that the species is used medicinally by the Aborigines but no details are given.

Kükenthal (1935-36) cited a specimen, 'Forrest, Fortescue River', under C. dactylotes. This may belong rather to $C$. ixiocarpus, which species Kükenthal did not even mention.

SELECTED SPECIMENS (41 examined): QUEENSLAND: Burke: Mt Isa, Leichhardt R., Blake 8755, Apr 1935 (BRI, K), Wilson 5481, May 1983 (NSW, BRI); 12 miles [19 km] S of Mt Isa township, Perry 774, May 1948 (CANB, AD, BRI, K, MEL, NSW, NT). NORTHERN TERRITORY: Central North: Crown Creek, 5 miles [8 km] W of Coniston HS., Chippendale 2078, May 1956 (NT, BRI, CANB, MEL, NSW); Utopia HS., Green, Dec 1977 (NT 54058, NSW); Landers Creek, Hill 318, June 1911 (MEL); Waite Creek, $28 \mathrm{~km}$ SE of Vaughan Springs, Latz 8670, May 1981 (CBG, NSW ex NT); Jinka Station, Latz 9618, July 1983 (NSW); Hanson R., c. 1 km WNW of Stuart Monument, Wilson 4657, Apr 1983 (NSW). Central South: Hay R. c. 14 km SSE of Mt Winnecke, Purdie 2338, July 1982 (CANB, CBG). WESTERN Australia: Fortescue: The Pool, Marble Bar, Beauglehole \& Carr 48405, Aug 1974 (MEL, NSW, NT); Coongan R., Warralong Station, Burbidge 690, May 1941 (PERTH); Stoneyard Creek, Muccan Station, Burbidge 909, June 1941 (BRI, PERTH); Corong Creek, Woodstock Station S of Port Hedland, Burbidge 5840, Apr 1958 (CANB, BRI, PERTH); Yule R. watershed, northernmost crossing of Beabea Creek, by main Wittenoom-Newman road, Jackson 2962, Aug 1977 (AD); near old Shay Gap Construction Camp, c. $165 \mathrm{~km}$ E of Port Hedland, Newbey 10266, July 1984 (PERTH); 14 km N of Abydos siding on Port Hedland road, Symon 10083, May 1975 (AD, NSW, NT). Carnarvon: Gascoyne R., at crossing by NW Coastal Highway, Jackson 3095, Aug 1977 (AD). Ashburton: Barlee Range, Robinson, Sep 1959 (PERTH). Keartland: Rudall R., George 10663, May 1971 (PERTH), Aug. 1971 (PERTH).

\section{Cyperus viscidulus K.L. Wilson}

Wilson (1980: 462, pl.27, figs. c-f).

Type: Western Australia: 15 miles [24 km] N of Bow River Station, Kimberleys, $M$. Lazarides 5053, 15 Apr 1955; holo NSW; iso AD, BRI, CANB, K, NT, P, PERTH.

Cyperus sporobolus R. Br. var. sexflorus (R. Br.) Benth. ex Kükenthal (1935-36: 457), p.p. min. (Mueller, Oberer Victoria-River). 
[Cyperus carinatus auct. non R. Br.: Bentham (1878: 274), p.p. min.; Ewart \& Davies (1917: 55),.p.p. (Mueller, McAdam Range)]

[C. sporobolus auct. non R. Br.: Bentham (1878: 281), p.p. min.; Ewart \& Davies (1917: 56), p.p. (Mueller, Upper Victoria River)]

Tall, slender perennial, tufted, 70-115 cm high, with spikelets usually viscid at maturity. Culms trigonous to terete, smooth, $1.5-3.5 \mathrm{~mm}$ diam. Leaves flat or canaliculate or occasionally carinate, mostly septate-nodulose, $\leq$ culms, to $4.5 \mathrm{~mm}$ wide, yellowgreen to mid-green; midrib often not obvious abaxially, but if obvious then often more strongly aculeate than margins; marginal prickles sparse to dense, regularly spaced (0.1-1.0 mm apart), very short to short, $<0.05-0.1 \mathrm{~mm}$ long, antrorse to erect, aculeate to papillate; leaf sheaths not septate-nodulose, not smooth or shining, stramineous with dark red-brown blotches. Inflorescence compound to decompound, often somewhat lax, 8-14(-c.25) slender primary branches to $21 \mathrm{~cm}$ long; bracts erect to spreading, 1-3 exceeding the inflorescence. Spikelets few to c. 12 in loose, subdigitate, hemispherical or globose clusters of $0.7-2.5 \mathrm{~cm}$ diam.; spikelets compressed, oblong, 5-17 mm long, 2.0-2.5 mm wide in side view, (4-)6-26-flowered, usually viscid; rachilla often thickened at maturity (to $0.1 \mathrm{~mm}$ thick), not to narrowly winged, wings to $0.05 \mathrm{~mm}$ wide; glume spacing $1.0-1.5 \mathrm{~mm}$; spikelet with glumes falling individually and rachilla persistent, or often units of branch plus spikelets falling. Glumes ovate to elliptic, retuse to acute with straight mucro $<0.1-0.2 \mathrm{~mm}$ long, stramineous to golden-brown with green midrib, 1.7-2.3 mm long, $0.5-0.7 \mathrm{~mm}$ wide, sides 2-3-nerved with nerves very distinct because of viscidity of spikelet, margins broad-hyaline and not inrolled. Anthers $0.4-0.8 \mathrm{~mm}$ long excluding appendage $0.1-0.2$ $\mathrm{mm}$ long. $\mathrm{Nut} \pm$ trigonous, obovate to elliptic with acute apex, adaxial face concave, other faces flat, dark red-brown to black, small-foveate to small-colliculate, shining, $1.5-1.8 \mathrm{~mm}$ long, $7 / 8$ as long as to equalling glume, $0.6-0.7 \mathrm{~mm}$ diam., often viscid and falling with glume because of viscidity. Figure $20 \mathrm{~g}-\mathrm{i}$.

Distribution: Kimberley region of Western Australia to Darwin \& Gulf region of the Northern Territory. Figure 18e.

HABITAT: Sandy to loamy soils; in seasonally wet situations (banks and beds of stream lines).

The species generally has viscid spikelets at maturity. It shares this characteristic with C. ixiocarpus (q.v.) and C. cunninghamii (q.v.). Superficially, it resembles C. sexflorus, but that species has bulbous culm bases and different spikelet details and it occupies a very different habitat. $C$. viscidulus occasionally grows with $C$. cunninghamii subsp. cheradicus and $C$. holoschoenus, but is readily distinguished on glume characters.

SeleCTED SPECIMENS (34 examined): NorTHERN TerRITORY: Darwin and Gulf: $70 \mathrm{~km}$ from Katherine, near Fergus[s]on R., Blake 16088, Apr 1946 (BRI, NSW); 6 km S of Edith R. crossing on Stuart Highway, Wilson 4937, 4939, Apr 1983 (NSW); $6 \mathrm{~km}$ E of Stuart Hway on old track to Edith Falls, Wilson 4947, Apr 1983 (NSW). Victoria River: 6 km NE of Mt Frederick, NW Tanami Desert, Latz 8599, 8600, Mar 1981 (NT, NSW); Upper Victoria R., Mueller, - (K, PERTH); Victoria Highway, $27.6 \mathrm{~km}$ NE of Victoria R. crossing, Wilson 4901, Apr 1983 (NSW). WeSTERN AUSTRALIA: Gardner: Mitchell Plateau, W of Lone Dingo, Beard 8317, Feb 1979 (PERTH); c. $6.5 \mathrm{~km} \mathrm{~W}$ of King R., S side of Cockburn Range, Beauglehole \& Carr 47240, July 1974 (MEL, NSW, NT); Mitchell R., Dunlop 5231, Feb 1980 (NSW); Palmoondoora Creek above Morgan Falls, Drysdale R. National Park, George 14066, Aug 1975 (PERTH); junction Neville Creek and Calder R., Eastern Walcott Inlet, Kenneally 8706, May 1983 (PERTH); Carson R., $32 \mathrm{~km} \mathrm{E}$ of new Theda HS., Telford \& Butler 6123, July 1977 (CBG); $13 \mathrm{~km}$ S of Great Northern Highway on Moochalabra Dam road, Wilson 4875, Apr 1983 (NSW); Granite Creek, $11.7 \mathrm{~km}$ SW of Victoria Highway on Lake Argyle road, Wilson 4895, Apr 1983 (NSW). Dampier: Windjina Gorge, Napier Range, Beauglehole \& Carr 47687, July 1974 (MEL, NSW, NT). Fitzgerald: King Creek Gorge, c. $15 \mathrm{~km}$ SW of Bedford Downs.HS., Beauglehole 53607, June 1976 (NT); Lennard R. Gorge, King Leopold Range, Beauglehole \& Carr 
47753, July 1974 (MEL, NSW, NT); 13.5 miles [22 km] NW of Elgie Cliffs Station, Lazarides 5103, Apr 1955 (CANB, BRI, K, MEL, PERTH). Hall: Smoke Creek, SW of Lake Argyle, Weston 12158, Apr 1980 (PERTH, CANB).

15. Cyperus carinatus $R$. $B r$.

Brown (1810: 216); Poiret (1817: 187); Sprengel (1824: 227); Kunth (1837: 112); Steudel (1854: 54); Bentham (1878: 274), p.p. min.; Ewart \& Davies (1917: 55), p.p.; Kükenthal (1935-36: 457), p.p.; Wilson (1981a: 508, Figure 638I). Mariscus carinatus (R. Br.) C.B. Clarke (1908: 19); Domin (1915: 441), excluding specimens.

TYPE: NorTHERn TerRITORY: North Coast, R. Brown (Bennett 5899); holo BM; iso BRI (fragm.).

[C. holoschoenus auct. non R. Br.: Fitzgerald (1918: 117), p.p.]

Tall, robust perennial, tufted, bases rarely somewhat bulbous in young plants, 40-100 $\mathrm{cm}$ high, not viscid. Culms trigonous to terete, smooth, $1.5-3 \mathrm{~mm}$ diam. Leaves carinate or canaliculate, strongly septate-nodulose, $\geq$ culms, to $5 \mathrm{~mm}$ wide, bluish green; midrib obvious abaxially, smooth; marginal prickles sparse to dense, irregularly spaced (0.2-1.5 mm apart), short, c. $0.05 \mathrm{~mm}$ long, mixed antrorse aculeate and papillate; leaf sheaths mostly septate-nodulose, loose, of papery texture, not shining, pinkish to dark red-purple. Inflorescence simple to compound, (3-)6-17 primary branches to 17 $\mathrm{cm}$ long; bracts erect, (1-)2-3 exceeding inflorescence. Spikelets 12-numerous in \pm dense subdigitate, hemispherical clusters of $0.7-2 \mathrm{~cm}$ diam.; spikelets compressed, oblong to narrow-ovate, (3.5-)5-9(-14) $\mathrm{mm}$ long, 2-4 mm wide in side view, (4-)6-14(-32)flowered; rachilla usually not thickened (rarely to $0.1 \mathrm{~mm}$ thick), not or scarcely winged; glume spacing $0.7-1.2 \mathrm{~mm}$; spikelet with rachilla persistent and glumes falling individually. Glumes elliptic to ovate, broad-acute to retuse with straight mucro $<0.1-0.2 \mathrm{~mm}$ long, stramineous to golden brown with green midrib, 1.6-2.3 $\mathrm{mm}$ long, $0.4-0.8 \mathrm{~mm}$ wide, sides (2-)3-4-nerved, margins inrolled and usually broad whitemembranous (margins not obvious in mature spikelets because tightly inrolled around nut). Anthers $0.4-0.8 \mathrm{~mm}$ long excluding appendage $\leq 0.1 \mathrm{~mm}$ long. Nut trigonous, very narrow-elliptic to narrow-obovate with broad-acute and subglobose apex, all faces flat or two faces convex, pale yellow-brown to dark red-brown, smooth and reticulateareolate or small-colliculate, shining, $1.6-2.0 \mathrm{~mm}$ long, $\leq$ glume, $0.5-0.7 \mathrm{~mm}$ diam., falling with glume. Figure 21a-c.

Distribution: From the Dampier region of Western Australia to the North Kennedy District, Queensland. Figure 18f.

Habitat: Sandy to clay-loam soils in seasonally wet situations (banks and beds of streams, open swamps, roadside drains).

C. carinatus shows some resemblance to $C$. holoschoenus, $C$. orgadophilus, $C$. oxycarpus (q.v.) and C. sporobolus, but is readily distinguished by its glumes, which have broad white-membranous margins that clasp the nut. It is also distinguished from C. orgadophilus and $C$. sporobolus by the strongly bulbous culm-bases and shorter culms of the latter species. It differs further from C. holoschoenus (with which it often grows) in its blue-green leaves and culms, its mixed leaf marginal prickles, its pinkish bases, longer spikelets, and stouter nut. Depauperate herbarium specimens of $C$. carinatus have been mistaken for $C$. fulvus but the two species differ in glume shape, size and spacing, and in the colour of the culm bases. C. carinatus is generally larger and 'softer-textured' than $C$. fulvus, reflecting their different habitats.

The name $C$. carinatus was misapplied to specimens of $C$. congestus Vahl by Nees (in Lehmann 1846: 72) and to C. subulatus R. Br. by Boeckeler (1875: 84). 
SELECTED SPECIMENS (52 examined): QuEENSLAND: Cook: Gilbert R., Forest Home Station, Brass 1867, Apr 1931 (BRI). Burke: Blackbull, between Normanton and Croydon, Blake 9137, May 1935 (BRI, K, NSW, NT); 9 miles [15 km] W. Westmoreland Station, Perry 1279, June 1948 (CANB, BRI); Leichhardt R., $8 \mathrm{~km} \mathrm{~S}$ of Mt Isa, Wilson 5441, May 1983 (NSW). North Kennedy: Balfes Creek township, Wilson 5596, May 1983 (NSW). Gregory North: Pigeon Creek, $50 \mathrm{~km}$ NW of Dajarra on Mt Isa road, Wilson 5474, May 1983 (NSW). NORTHERN TERRITORY: Darwin and Gulf: Nutwood Downs Station, Blake 17602, May 1947 (BRI, K); McArthur R. area, c. $1 \mathrm{~km}$ from main road, Craven 3875, Feb 1976 (CANB); Gulf of Carpentaria, Maria Island, Dunlop 2847, July 1972 (NT); $5 \mathrm{~km} \mathrm{~W}$ of Roper Bar, Parker 919, June 1980 (CANB); $0.5 \mathrm{~km} \mathrm{~N}$ of Larrimah on Stuart Highway, Wilson 5276, May 1983 (NSW); Caranbirini Waterhole, c. $32 \mathrm{~km}$ SW of Borroloola, Wilson 5332, May 1983 (NSW). Victoria River: Gill Creek Bore, Latz 5379, June 1974 (NT, NSW); Victoria Highway, $23.5 \mathrm{~km}$ W of Timber Creek, Wilson 4774, Apr 1983 (NSW). Barkly Tableland: Calvert Hills Station, Seigal Creek, Henry 738, May 1973 (NT, AD); Mitchebo Waterhole, Mittibah Station, Maconochie 2613, Mar 1981 (NSW); Stuart Highway, North Hayward (Creek); Wilson 4690, Apr 1983 (NSW). Central North: Lander R. floodout, Henry 639, Mar 1973 (NT, BRI, CANB, NSW); Frew R., 5 km ENE of Epenarra HS., Latz 561, Mar 1970 (NT, BRI, L); Davenport Range, Latz 6921, May 1977 (NT, K, NSW); Stuart Highway, 8 km N of Wauchope, Wilson 4669, Apr 1983 (NSW). Western AuSTRALIA: Dampier: Molla-Oobagoona road, $6 \mathrm{~km} \mathrm{~N}$ of Gibb R. road, Beauglehole 52634, June 1976 (NT); Butler Lake, 'Meda', Jacobs 4275, May 1982 (NSW); Deep R., 5 km $\mathrm{N}$ of Point Coulomb, Kenneally 5918, Apr 1977 (PERTH), Kenneally 5926, Apr 1977 (PERTH, NSW); 25 miles $[40 \mathrm{~km}] \mathrm{E}$ of Derby on Beef Road, Power 241, Mar 1967 (PERTH).

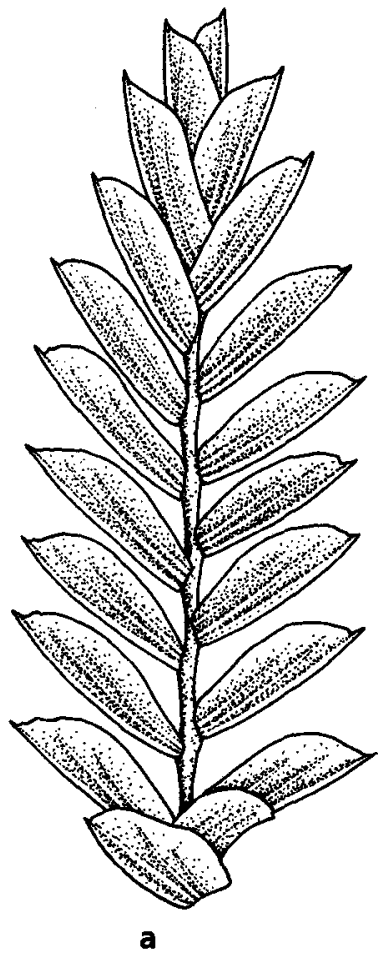

a
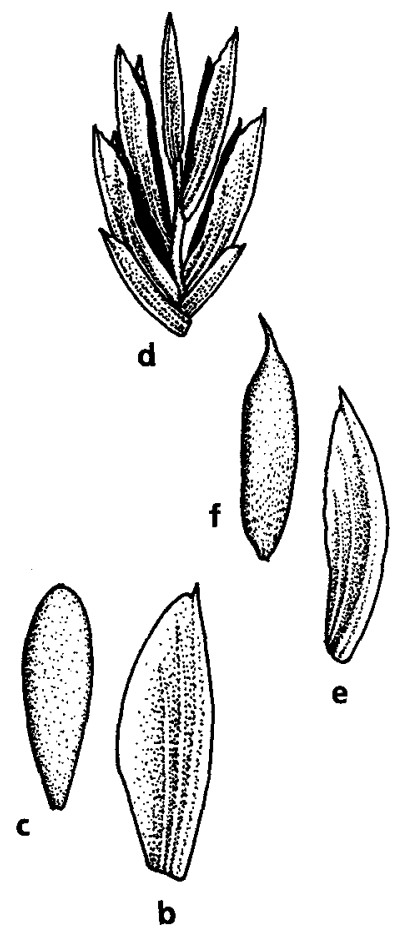

Figure 21. Spikelet details. C. carinatus: a, spikelet; b, glume; c, nut. C. holoschoenus: $\mathbf{d}$, spikelet; e, glume; f, nut. C. oxycarpus: $\mathbf{g}$, spikelet; $\mathbf{h}$, glume; $\mathbf{i}$, nut. a-c from Latz 5531; $\mathbf{d}-\mathbf{f}$ Olsen 2723; $\mathbf{g}-$ i Blake 9209. a, d, g X 11; b, c, e, f, h, i X 14. 
Several specimens from the Central North region of the Northern Territory are morphologically intermediate between $C$. carinatus and C. centralis, and indicate that the populations there require further study. The inflorescence shape, rather long surculi and long glumes are reminiscent of $C$. centralis but features of the leaves, glumes (other than length) and nuts tend to $C$. carinatus. Seed-set seems to be as high as in any of the taxa regarded as species in this group. The specimens are relatively uniform, and may represent a distinct taxon - perhaps even a stabilised hybrid of these two species. Geographically, most of these specimens occur at the southern limit of distribution of C. carinatus (which corresponds to the northern limit of C. centralis). Latz 5264 occurs farther south than the others. The habitat, as seen and as noted on herbarium specimen labels, is closer to that of $C$. carinatus than that of $C$. centralis, but the taxa have not been found growing together.

\section{Cyperus carinatus $X$ C. centralis?}

Robust perennial, tufted, often with long surculi, $55-80 \mathrm{~cm}$ high, not viscid. Culms trigonous to terete, smooth, 1.5-2 mm diam. Leaves flat or canaliculate, septatenoulose, about as long as culms, to $4.5 \mathrm{~mm}$ wide, bluish green, shining, somewhat fleshy; midrib occasionally obvious abaxially, smooth or scabrous; marginal prickles sparse, usually irregularly spaced, short to long, antrorse, erect, flabellate, aculeate (may be somewhat blunt); leaf sheaths not septate-nodulose, not smooth or shining, thin-textured, pale orange-brown. Inflorescence simple to small-compound, 6-11 primary branches to $6 \mathrm{~cm}$ long; bracts erect to spreading, 2 exceeding the inflorescence. Spikelets numerous in subdigitate, globose clusters of $0.7-1.5 \mathrm{~cm}$ diam.; spikelets compressed, oblong, 5-11 mm long, 2.5-3.5 mm wide in side view, 4-10-flowered; rachilla not thickened, not or narrowly winged, wings to $0.05 \mathrm{~mm}$ wide; glume spacing 1.3-1.5 mm; spikelet falling as a unit, or with rachilla persistent and glumes falling individually. Glumes ovate to elliptic, obtuse with straight mucro $\leq 0.1 \mathrm{~mm}$ long, stramineous to red-brown with yellow blotches and with green midrib, 2.4-3.0 mm long, 0.7-1.1 mm wide, sides 2-3-nerved, margins inrolled and rather broad whitemembranous or hyaline. Anthers $1.5-2.0 \mathrm{~mm}$ long excluding appendage $\leq 0.1 \mathrm{~mm}$ long. $\mathrm{Nut}$ trigonous, narrow-elliptic with broad-acute apex, faces flat, pale brown to dark grey-brown, foveate to smooth and reticulate-areolate, shining or glistening, $1.8-2.0 \mathrm{~mm}$ long, about $3 / 4$ as long as glume, $0.5-0.7 \mathrm{~mm}$ diam., falling with glume.

Distribution: Central North region of the Northern Territory. Figure 18f.

HABITAT: Locally wet situations (around waterholes in creeks and around large depressions amongst sand-dunes).

These specimens resemble $C$. carinatus in the following features: leaf colour, width, surface texture, and marginal prickles; nut colour, shape, surface and size; glume width, texture and broad margins. They are similar to $C$. centralis in: glume length; bases with long surculi; general appearance of the inflorescence.

SPECIMENS EXAMINED: NoRTHERN TerRITORY: Central North: Lander River, Henry 599, Mar 1973 (NT, BRI, NSW); Lake Surprise area, Henry 624, Mar 1973 (NT, NSW); Elkedra River, Latz 2239, Feb 1972 (NT, BRI, NSW); Umbeara Station, Latz 5264, May 1974 (NT, NSW); Utopia Station, Latz 6727, Mar 1977 (NT, BRI, NSW); Elkedra Station, Davenport Range, Latz 6974, May 1977 (NT, NSW); Lake Surprise, Latz 9888, May 1984 (NSW ex NT); Sandover Highway, 19 km NE of Utopia turnoff, Wilson 4647, Apr 1983 (NSW).

16. Cyperus holoschoenus $R$. Br.

Brown (1810: 215); Poiret (1817: 187); Sprengel (1824: 227); Kunth (1837: 111); Steudel (1854: 54); Mueller (1859: 200); Mueller (1874: 262); Bentham (1878: 273), p.p. max.; Bailey (1902: 1741), p.p. max.; Ewart \& Davies (1917: 55); Fitzgerald (1918: 117), p.p.; 
Kükenthal (1935-36: 481); Kükenthal (1940b: 463); Blake (1947b: 223); Kern (1963: 27); Kern (1974: 637). Mariscus holoschoenus (R. Br.) C.B. Clarke (1908: 19); Domin (1915: 441), p.p. max.

TyPE: NORTHERN Territory: Carpentaria island h [North Island, Sir Edward Pellew Group], R. Brown (Bennett 5901); lecto BM (here designated); iso BM.

Cyperus holoschoenus var. fuscisquamatus Kükenthal (1940a: 301), as 'fusci-squamatus'. TYPE: PAPUA: Western Division: Dagwa, Oriomo River, L. Brass 5920, Feb-Mar 1934; holo B, n.v.; iso BRI.

Tall, robust perennial, tufted, occasionally with a somewhat bulbous base in young plants, $55-120 \mathrm{~cm}$ high, not viscid. Culms obscurely trigonous to terete, smooth, $1.5-$ $5 \mathrm{~mm}$ diam. Leaves canaliculate or occasionally folded, strongly septate-nodulose, $1 / 2-2 / 3$ length of culms, to $7 \mathrm{~mm}$ wide, yellow-green; midrib often obvious abaxially towards the apex and more scabrous than the margins, not obvious below; marginal prickles sparse to very sparse (nearly absent at maturity), regularly spaced $(0.3-3.0 \mathrm{~mm}$ apart), short, c. $0.05 \mathrm{~mm}$ long, antrorse, aculeate; leaf sheaths septate-nodulose, \pm smooth and shining, pinkish to red-brown. Inflorescence small-compound to decompound, open, 5-11 primary branches to $15 \mathrm{~cm}$ long; bracts erect, (1-)2-3 exceeding the inflorescence, occasionally the bracts subtending each spikelet cluster well-developed and obvious when young. Spikelets numerous in dense, subdigitate, hemispherical or occasionally globose clusters of $0.2-1.2 \mathrm{~cm}$ diam.; spikelets \pm compressed, oblong or narrow-ovate, $2.5-5.5 \mathrm{~mm}$ long, $1.5-3.0 \mathrm{~mm}$ wide in side view, 2-6(-8)-flowered; rachilla not thickened, not or narrowly winged, wings to $0.05 \mathrm{~mm}$ wide; glume spacing $0.5-0.9 \mathrm{~mm}$; spikelet with rachilla persistent and glumes falling individually. Glumes narrow-elliptic to narrow-ovate, \pm curved, spreading widely at maturity (nearly flat), acute with straight mucro $<0.1-0.2 \mathrm{~mm}$ long, stramineous (yellowish when young) to red-brown with a green midrib (occasionally scaberulous near apex), 1.3-2.1 mm long, $0.4-0.6 \mathrm{~mm}$ wide, sides 2-5-nerved, margins not or only slightly inrolled and only very narrow-membranous. Anthers $0.4-0.8 \mathrm{~mm}$ long excluding appendage $<0.1-0.3 \mathrm{~mm}$ long. Nut trigonous, very narrow- to narrow-elliptic with acuminate apex, usually at least the adaxial face concave, pale red-brown to grey-brown, smooth and reticulateareolate to small-colliculate, shining, $1.3-2.0 \mathrm{~mm}$ long, $\geq$ glume, $0.4-0.6 \mathrm{~mm}$ diam., falling separately from glume or with it. Figure $21 \mathrm{~d}-\mathrm{f}$.

DistRIBUTION: From the Kimberley region of Western Australia to the Cook District, Queensland. Also southern New Guinea. Figure 22a.

HABITAT: Sandy to clay soils; seasonally wet sites (banks of streams and lagoons, open swamps).

C. holoschoenus is a distinctive species in its robust habit, and its large inflorescence with small globose spikelet-clusters and small thin-textured glumes that are spread nearly flat at maturity (unlike all other species in this Section). C. dactylotes (q.v.) is also robust with small glumes but there the resemblance ends. $C$. holoschoenus often grows with the related C. carinatus (q.v.) or C. oxycarpus. It can be readily distinguished from both species on glume size, and nut shape and size.

Tate (1890) cited this species as occurring in South Australia. It is likely that he was referring to $C$. alterniflorus or $C$. dactylotes.

SELECTED SPECIMENS (136 examined): QUEENSLAND: Cook: on Wrotham Park, c. 50 miles [80 km] NW of Mungana, Blake 13708, Apr 1938 (BRI, K); Lockerbie, 10 miles [16 km] WSW of Somerset, Brass 18633, May 1948 (BRI, CANB). Burke: 6 miles [10 km] W of Westmoreland Station, Perry 1329, June 1948 (CANB, BRI, NT); Barkly Highway, $46 \mathrm{~km}$ SE of Camooweal, Wilson 5421, May 1983 (NSW, AD, BRI, NT). North Kennedy: Pentland, Blake 6046, June 1934 (BRI, K, NSW); Burra Range, Sharpe 2835, July 1981 (BRI, NSW). NORTHERN TeRRITORY: Darwin and Gulf: Nutwood 
Downs Station, Blake 17601, May 1947 (BRI, CANB, K, MEL); 17 miles [27 km] N Wilton R. crossing, Latz 2758, June 1972 (CANB, NSW); Emerald R., Groote Eylandt, Levitt 286, May 1973 (DNA, NT); King R., 25 miles [40 km] S of Katherine, McKee 8456, Feb 1961 (CANB, K, NSW, NT); 1 km S of Ja Ja Billabong, near Jabiluka, Sanderson NSW 156176, Mar 1982 (NSW, DNA); Pine Creek, Tindale \& Dunlop 6005, July 1979 (CANB, K, NSW); 22 km N of Tanumbirini HS., Wilson 5309, May 1983 (NSW, AD, BRI, CANB, DNA). Victoria River: Buchanan Highway, 39 km E of Top Springs Roadhouse, Wilson 4732, Apr 1983 (NSW); Saddle Creek, Victoria High-

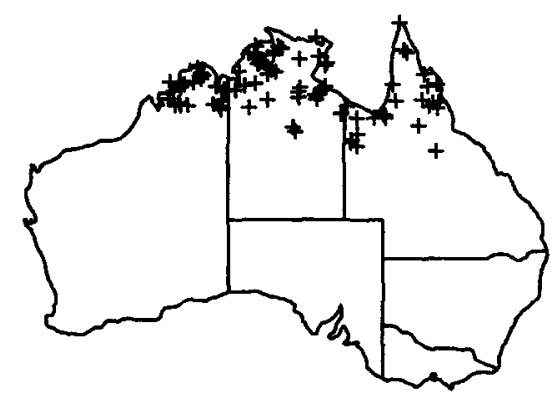

a $\square$

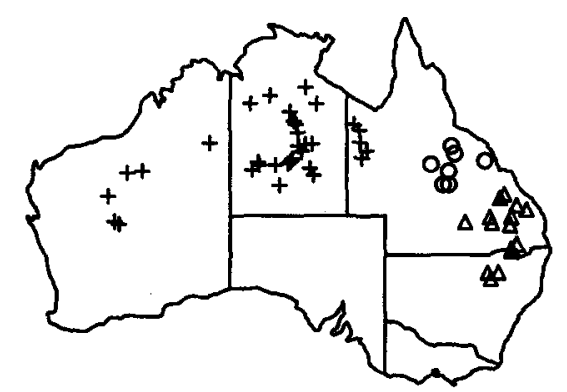

c $\bigcirc$

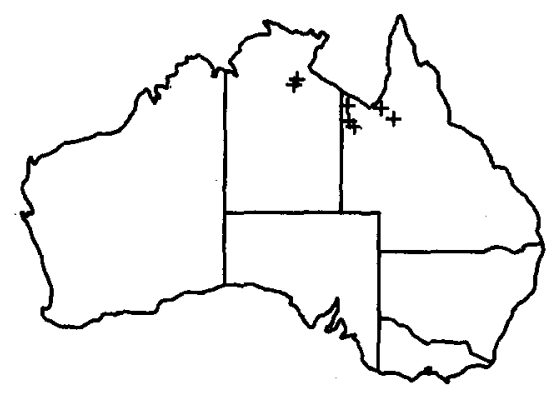

e $\square$

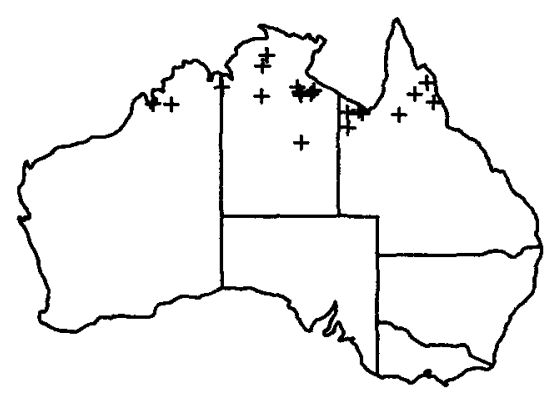

b $\square$
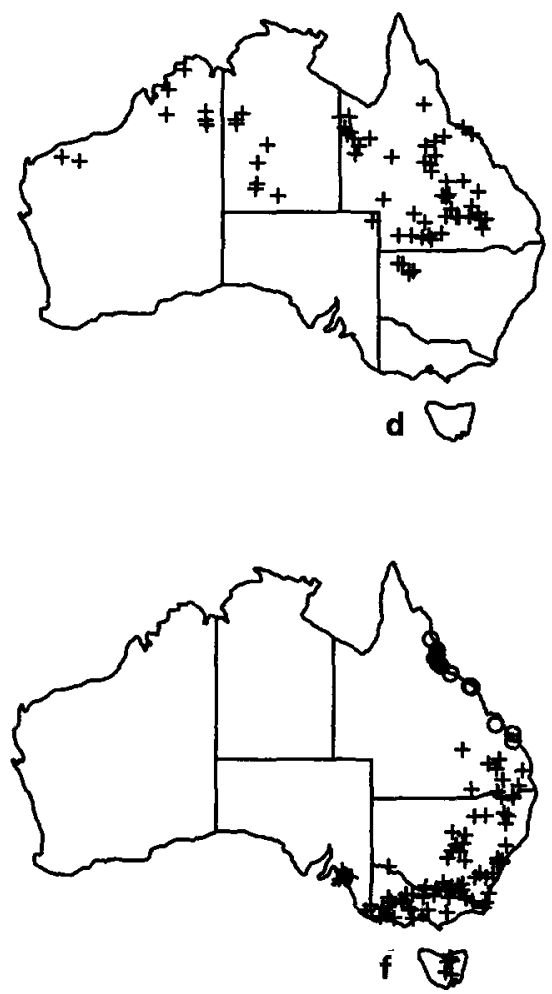

Figure 22. Distribution of: a, C. holoschoenus (New Guinea occurrences not mapped); b, C. oxycarpus; c, C. betchei subsp. betchei (open triangles), C. betchei subsp. commiscens (crosses) and apparent intergrades (open circles); d, C. dactylotes; e, C. fucosus; f, C. gunnii subsp. gunnii (crosses) and C. gunnii subsp. novae-hollandiae (open circles). 
way, Wilson 4783, Apr 1983 (NSW, DNA, PERTH). Barkly Tableland: Stuart Highway, N Hayward (Creek), Wilson 4691, Apr 1983 (NSW, AD, CANB, DNA, K, PERTH). WeSTERN AusTRALIA: Gardner: Planigale Creek, Drysdale R. National Park, Kenneally 5597, Aug 1975 (PERTH, CANB); Longini Landing, near Kalumburu, Symon 10193, May 1975 (AD, NSW, NT); Augustus I., Bonaparte Archipelago, P. Wilson 10836, May 1972 (PERTH). Fitzgerald: Edkins R., 12 miles [19 km] NW of Glenroy Meatworks, Lazarides 5152, Apr 1955 (CANB, BRI, K, NSW, NT, PERTH). Hall: SE Kimberley region, Mabel Downs, Winnama Spring, Forbes 2033, May 1984 (NSW ex MEL). New Guinea: Papua New Guinea: Morehead R., c. 8 miles [13 km] inland, Western District, Pullen 7036, Aug 1967 (CANB, BRI).

\section{Cyperus oxycarpus S.T. Blake}

Blake (1940: 46)

TYPE: QuEENSLAND: Burke: Wernadinga, between Normanton and Burketown, S.T. Blake 9209, 31 May 1935; holo BRI; iso K, MEL, NSW.

\section{[C. holoschoenus auct. non R. Br.: Fitzgerald (1918: 117), p.p.]}

Tall, robust perennial, tufted, with somewhat bulbous bases when young, $30-80 \mathrm{~cm}$ high, not viscid. Culms trigonous, smooth, 1.5-2 mm diam. Leaves flat to carinate, septate-nodulose, $\geq$ culms, to $4 \mathrm{~mm}$ wide, yellow-green; midrib obvious abaxially, usually smooth; marginal prickles sparse, regularly spaced $(0.2-1.5 \mathrm{~mm}$ apart), short, $0.05-0.10 \mathrm{~mm}$ long, antrorse, aculeate (nearly absent at maturity); leaf sheaths may be septate-nodulose, smooth, shining, yellow-brown to red-brown, with broad whitish membranous margins. Inflorescence simple to compound, 5-9 primary branches to 8 $\mathrm{cm}$ long; bracts erect, (2-)3-5 exceeding the inflorescence. Spikelets numerous in dense subdigitate, hemispherical to globose clusters of $0.5-1.5 \mathrm{~cm}$ diam.; spikelets compressed or occasionally subterete in crowded clusters, oblong to narrow-ovate, 4-10 $\mathrm{mm}$ long, $2.5-3.5 \mathrm{~mm}$ wide in side view, 4-6(-18)-flowered; rachilla not thickened, not or narrowly winged, wings to $0.05 \mathrm{~mm}$ wide; glume spacing $0.7-1.2 \mathrm{~mm}$; spikelet with rachilla persistent and glumes falling individually. Glumes narrow-ovate, longacute with straight mucro $0.1-0.2 \mathrm{~mm}$ long, stramineous, with green midrib, 2.4-3.0 $\mathrm{mm}$ long, 0.5-0.7 mm wide, sides (2-)3-4-nerved, margins very narrow-membranous and not or only slightly inrolled, glumes spreading at maturity. Anthers $0.4-0.7(-1.2)$ $\mathrm{mm}$ long excluding appendage $<0.1(-0.2) \mathrm{mm}$ long. Nut trigonous, very narrow-elliptic to narrow-ovate with acuminate apex, faces flat or concave, pale yellow-brown to dark golden-brown, smooth and reticulate-areolate, shining, 1.6-2.2 mm long, $2 / 3-$ $7 / 8$ as long as glume, $0.4-0.5 \mathrm{~mm}$ diam., falling with glume. Figure $21 \mathrm{~g}-\mathrm{i}$.

DisTRIBUTION: From the regions bordering the Gulf of Carpentaria (Cook, Burke and Darwin \& Gulf Districts) to the Kimberley region of Western Australia. Figure 22b.

НАвттAт: Clayey soils, in seasonally wet sites (banks of lagoons, creek levees, roadside drains).

C. oxycarpus is another robust northern species, related to $C$. holoschoenus (q.v.) and C. carinatus (q.v.), and found in similar ephemerally wet habitats. It has a distinctive narrow, elongate nut (as suggested by the epithet) and long glumes that are arranged so as to give a chevron-like appearance to the mature spikelets.

SELECTED SPECIMENS (24 examined): QUEENSLAND: Cook: Little R., ESE of Croydon, Beauglehole 55119, July 1976 (NT); on Wrotham Park, c. 50 miles [80 km] NW of Mungana, Blake 13712, Apr 1938 (BRI); Springmount Station, Goodall 47, July 1960 (BRI); c. $10 \mathrm{~km} \mathrm{~W}$ of E Normanby R., $60 \mathrm{~km}$ S of Cooktown, Sharpe 1487, June 1975 (BRI). Burke: O'Shanassy R., Blake 8637, Apr 1935 (BRI); 38 miles [61 km] N of Thorntonia Station, Perry 1078, May 1948 (CANB, BRI, MEL, NSW, NT); 51 miles [82 km] N Lawn Hill, Perry 1129, June 1948 (CANB, BRI); Harris Lake, 9 km SE of Burketown, Wilson 5574, May 1983 (NSW, BRI, DNA). NORTHERN TERRTTORY: Darwin and Gulf: 

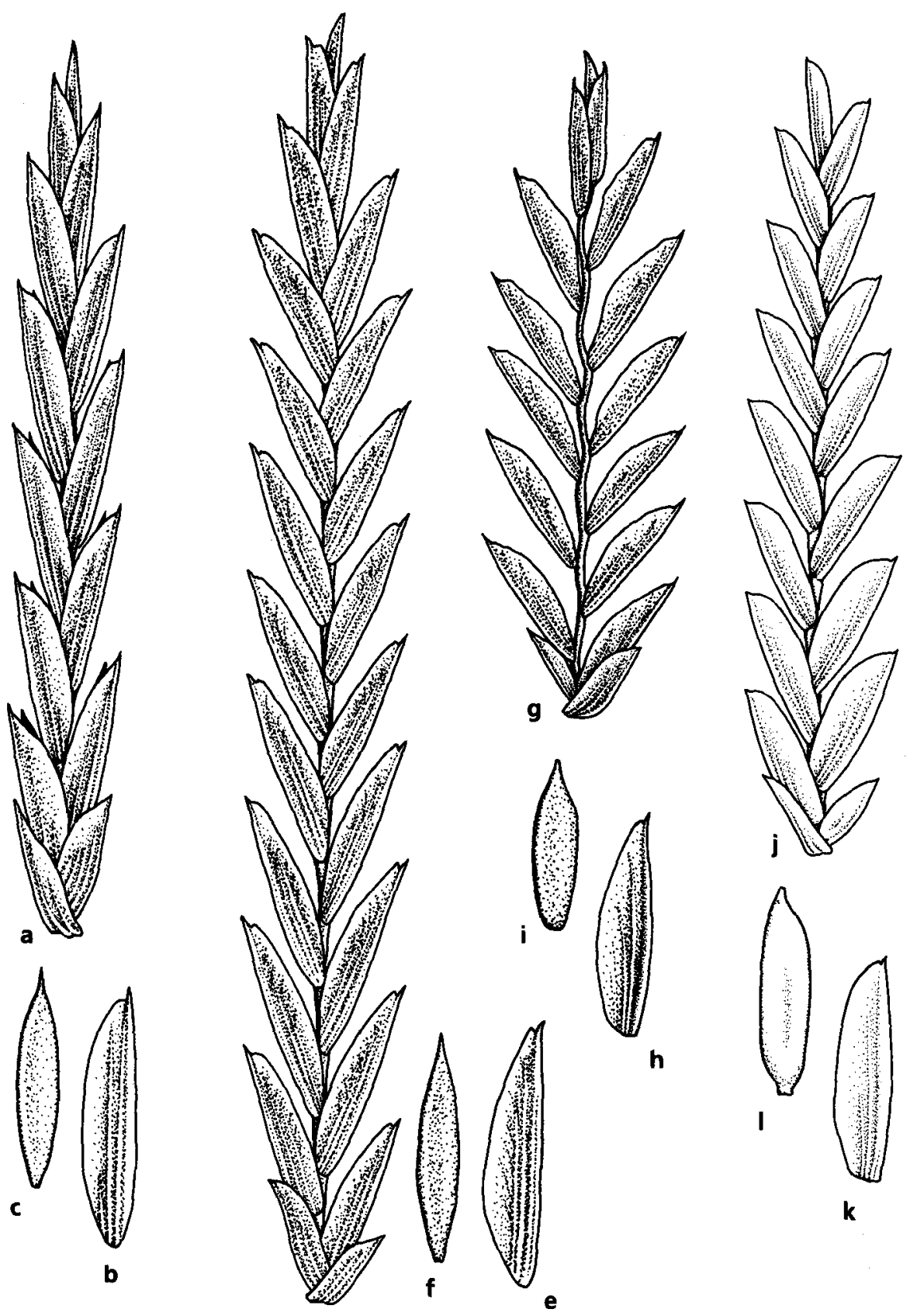

Figure 23. Spikelet details. C. betchei subsp. betchei: a, spikelet; b, glume; c, nut. C. betchei subsp. commiscens: d, spikelet; e, glume; $\mathbf{f}$, nut. C. dactylotes: $\mathbf{g}$, spikelet; $\mathbf{h}$, glume; $\mathbf{i}$, nut. C. fucosus: $\mathbf{j}$, spikelet; $\mathbf{k}$, glume; $\mathbf{1}$, nut. a-c from Wilson 746; d-f Latz 7090; $\mathbf{g}-\mathbf{i}$ Latz 5126; j-l Wilson 5500. a, $\mathrm{d}, \mathrm{g}, \mathrm{j} \times 11 ; \mathrm{b}, \mathrm{c}, \mathrm{e}, \mathrm{f}, \mathrm{h}, \mathrm{i}, \mathrm{k}, \mathrm{l} \times 14$. 
O.T. Station, Blake 17710, May 1947 (BRI); Leila Lagoon, 63 miles [101 km] SW Borroloola, Chippendale 5535, Mar 1959 (NT, AD, BRI, CANB, K, MEL, NSW, PERTH); Tanumbirini Creek, Latz 7298, July 1977 (NT, CANB, NSW); just N of S Alligator R. on El Sharana road, Wilson 5240, May 1983 (NSW, DNA); Caranbirini Waterhole, Wilson 5333, May 1983 (NSW, BRI, DNA, K, P, PERTH). Victoria River: Keep River National Park, Dunlop 5850, Mar 1981 (NSW, PERTH ex DNA); Buchanan Highway, $39 \mathrm{~km}$ E of Top Springs, Wilson 4731, Apr 1983 (NSW, DNA). Barkly Tableland: 90 miles [145 km] E of Newcastle Waters, Perry 340, July 1947 (CANB). WesteRn Australia: Fitzgerald: Billyara Dam, 'Napier Downs', Jacobs 5636 \& P. Wilson, May 1988 (NSW). Dampier: Goody Goody, Fitzgerald 21, Apr 1905 (PERTH, BRI, NSW); May R., Fitzgerald 52, May 1905 (NSW); Meda, Fitzgerald 401, Apr 1905 (PERTH).

\section{Cyperus betchei (Kük.) S.T. Blake}

Blake (1940: 43)

Tall perennial, tufted, often forming big tussocks, 35-120 cm high, not viscid. Culms trigonous to terete, smooth, $1.2-4 \mathrm{~mm}$ diam. Leaves flat to carinate or canaliculate, often septate-nodulose, $\leq$ culms, to $6 \mathrm{~mm}$ wide; midrib often obvious abaxially, usually smooth; marginal prickles sparse to dense, regularly or irregularly spaced $0.1-1.6 \mathrm{~mm}$ apart), long to short, $0.05-0.2 \mathrm{~mm}$ long, antrorse to erect, aculeate or papillate; leaf sheaths \pm septate-nodulose, striate or smooth, pinkish to chestnut-brown to black, with margins hyaline or white-membranous at base with red dots. Inflorescence smallcompound to compound, 4-12 primary branches to $16 \mathrm{~cm}$ long; bracts erect to spreading, septate-nodulose, (1-)2-3 much exceeding the inflorescence. Spikelets few (4-9) in spicate to subdigitate, loose, hemispherical clusters of $1.5-6.5 \mathrm{~cm}$ diam.; spikelets compressed, oblong, (5-)9-43 mm long, 1.2-2.8 mm wide in side view, (6-)10-48-flowered; rachilla not thickened, narrowly to broadly winged, wings 0.05$0.2 \mathrm{~mm}$ wide; glume spacing $1.3-2.3 \mathrm{~mm}$; spikelet falling as a unit, or rachilla persistent and glumes falling individually. Glumes narrow-ovate to narrow-elliptic, retuse to acute or obtuse with mucro $0.1-0.6 \mathrm{~mm}$ long and \pm excurved or straight, golden-brown to dark red-brown (or occasionally stramineous) with a green midrib, 2.0-3.4 mm long, 0.5-0.8 mm wide, sides 2-4-nerved, margins not or slightly inrolled and very narrow-membranous. Anthers $0.7-1.4 \mathrm{~mm}$ long excluding appendage $\leq 0.1$ $\mathrm{mm}$ long. Nut trigonous, very narrow-elliptic to very narrow-obovate with long-acute to acute apex, faces flat, pale yellow-brown, colliculate to smooth and reticulateareolate, shining, $1.8-2.5 \mathrm{~mm}$ long, $3 / 4$ as long as to equalling glume, $0.4-0.5 \mathrm{~mm}$ diam., falling with glume. Figure 23a-f.

Distribution: Northern edge of the arid zone, extending to the Pilbara region of Western Australia and in the east to the Pilliga Scrub area, northern New South Wales. Figure 22c.

C. betchei is closely related to $C$. dactylotes. It can be distinguished by its more obvious abaxial leaf midrib, its inflorescence with the usually larger but sparser clusters of spikelets, the often longer spikelets with more flowers, the greater glume spacing, the usually longer glume mucro, longer anthers and nut, and its often longer surculi.

Plants of subsp. betchei differ in aspect from those of the closely related subsp. commiscens: the leaf bases are usually not smooth, the culms are relatively more slender, the inflorescences are smaller, spikelets are narrower, and glume spacing is often greater. The differences are slight but are sufficient to give a different facies to specimens. Specimens from north-eastern Queensland (mapped as 'apparent intergrades', Figure 22c) generally have the characters of subsp. betchei except that the leaf bases are smooth as in subsp. commiscens. 
The subspecies of $C$. betchei can be distinguished as follows:

1 Spikelet width $1.2-2.0 \mathrm{~mm}$ in side view; glume mucro $0.1-0.2 \mathrm{~mm}$ long; leaf bases usually striate; rachilla wings $0.1-0.2 \mathrm{~mm}$ wide; culm diameter $1.3-2.7 \mathrm{~mm}$; inflorescence usually relatively small and compact, with 4-7 primary branches to $10 \mathrm{~cm}$ long

a. subsp. betchei

1 Spikelet width $2.0-3.2 \mathrm{~mm}$ in side view; glume mucro $0.2-0.5 \mathrm{~mm}$ long; leaf bases usually smooth; rachilla wings $<0.05-0.10 \mathrm{~mm}$ wide; culm diameter $1.4-4.0 \mathrm{~mm}$; inflorescence usually large and spreading with (5-)8-12 primary branches to $16 \mathrm{~cm}$ long

b. subsp. commiscens

18a. C. betchei subsp. betchei

Cyperus betchei (Kük.) S.T. Blake (1940: 43); Wilson (1987: 1135); Sharpe (1989: 324, Figure 47H). C. angustatus R. Br. var. betchei Kükenthal (1935-36: 452).

TyPe: New SOuth WaLEs: North Western Plains: Narrabri, E. Betche NSW 153088, Jan 1883; lecto NSW (Blake 1940); isolecto MEL.

[C. dactylotes auct. non Benth.: Moore \& Betche (1893: 448), p.p.]

Tall slender perennial, 35-100 cm high. Culms $1.3-2.7 \mathrm{~mm}$ diam. Leaves flat to canaliculate; midrib obvious abaxially, scabrous or smooth; marginal prickles irregularly spaced (0.1-0.9 mm apart), long, 0.1-0.2 $\mathrm{mm}$ long, antrorse, aculeate; leaf sheaths striate or occasionally smooth, pinkish to chestnut-brown to black. Inflorescence smallcompound to compound, 4-7 primary branches to $10 \mathrm{~cm}$ long; bracts (1-)2-3 exceeding the inflorescence. Spikelets in very loose clusters of $2.5-6.5 \mathrm{~cm}$ diam.; spikelets (5-)9-43 mm long, 1.2-2.0 mm wide in side view, 10-45-flowered; rachilla broadly winged, wings $0.1-0.2 \mathrm{~mm}$ wide; glume spacing $1.6-2.3 \mathrm{~mm}$. Glumes narrow-ovate to narrow-elliptic, retuse to obtuse with mucro $0.1-0.2 \mathrm{~mm}$ long and straight to excurved, yellow to dark golden-brown, 2.5-3.4 mm long, sides 2-3-nerved, margins \pm inrolled and very narrow-membranous. Anthers $0.8-1.4 \mathrm{~mm}$ long. Nut very narrowelliptic with long-acute apex, 1.9-2.2 mm long, $7 / 8$ as long as glume to equalling glume length. Figure 23a-c.

DistRibution: Central and south-eastern Queensland (south from about the Tropic of Capricorn) to the northern part of the Pilliga Scrub in New South Wales. Figure 22c.

HaBiTAT: Sandy-loam to clay soils; in at least seasonally wet situations (banks of creeks, billabongs, roadside drains, floodways).

SELECTED SPECIMENS (38 examined): QueENSLAND: Leichhardt: Nine Mile Creek, $14 \mathrm{~km} \mathrm{~N}$ of Banana, Wilson et al. 3637, May 1981 (NSW). Burnett: 32 miles [51 km] N of Chinchilla, McDonald 455, Feb 1970 (BRI, AD, CANB, K, NSW); c. $1.5 \mathrm{~km}$ SE of Abercorn, Wilson \& Sharpe 3749, May 1981 (BRI, NSW). Wide Bay: $1.5 \mathrm{~km}$ NE of Didcot, Forster 38, May 1986 (NSW ex BRI). Darling Downs: Chinchilla, Blake 7668, Feb 1935 (BRI, K); 7 Mile Rocky Creek near Chinchilla, Lithgow, Nov 1977 (BRI 230426); Surcingle Creek, c. $10 \mathrm{~km}$ N of Chinchilla, Sharpe \& Simon 2525, Feb 1979 (K, NSW ex BRI); between Inglewood and Milmerran, White 9692, Jan 1934 (BRI, CANB, K); $1.5 \mathrm{~km}$ W of Baking Board railway siding, Wilson et al. 3397, Apr 1981 (NSW, BRI, K, P); $10 \mathrm{~km} \mathrm{~W}$ of Dulacca on Roma road, Wilson et al. 3406, Apr 1981 (NSW, BRI). Maranoa: 20 miles [32 km] W of Mitchell, Blake 10970, Apr 1936 (BRI); $5 \mathrm{~km}$ E of Wallumbilla, Wilson et al. 3416, Apr 1981 (NSW). NEW SOUTH WALES: North Western Slopes: rail crossing c. 4 km from Kenebri, Wilson 740, Nov 1974 (NSW, P). North Western Plains: Sandy Creek, $9 \mathrm{~km}$ SSE of Narrabri, Coveny $\mathcal{E}$ Roy 8664, Nov 1976 (NSW, K, P); $28 \mathrm{~km}$ N of Baradine on Pilliga road, Payne 4, Jan 1976 (NSW, BRI, K, L, P, US); Talluba Ck, $17 \mathrm{~km}$ E of Pilliga on Wee Waa road, Wilson 6062, Nov 1984 (NSW, P); $5 \mathrm{~km} \mathrm{SSW}$ of Pilliga-Wee Waa road on 'Tregoen' road, Wilson 6059, Nov 1984 (NSW, P). 
Possible intergrades with subsp. commiscens:

Queensland: Leichhardt: Nebo Shire, 'Wavering Downs', Anderson, Feb 1978 (BRI 231414). Mitchell: Geera, E of Barcaldine, Blake 10373, Dec 1935 (BRI); Springvale, Clemens, Apr. 1946 (K); Tower Hill, White, Apr 1919 (BRI 186381, 186382); Dandy Creek, c. $1 \mathrm{~km}$ S of Eastmere HS., Wilson \& Sharpe 3548, May 1981 (NSW, BRI, P).

18b. C. betchei subsp. commiscens K.L. Wilson, subsp. nov.

Subsp. betchei maxime similis sed basibus foliorum laevibus, culmis robustioribus, inflorescentiis longioribus, spiculis latioribus, intervallo inter glumas saepe minor, differt.

Type: Northern Territory: Barkly Tableland: Stuart Highway, $16 \mathrm{~km}$ NW of Banka Banka P.O., K.L. Wilson 4709, 19 Apr 1983; holo NSW; iso BRI, K. Figure 24a.

C. dactylotes Bentham (1878: 273), p.p. min. (McDougall Stuart, Attack Creek).

[C. dactylotes auct. non Benth.: Domin (1915: 428), p.p. min.; Ewart \& Davies (1917: 55), p.p. (McDougal [sic], Attack Creek); Kükenthal (1935-36: 452), p.p. min. (McDougall Stuart 73, Attack Creek); Wilson (1981a: 506), p.p.]

[C. fulvus auct. non R. Br.: Mueller (1874: 268), p.p. min. (Stuart, Attack Creek); Mueller \& Tate (1890: 106); Mueller in Tate (1896: 181), as to Tietkens, Glen Helen]

Robust perennial, $70-120 \mathrm{~cm}$ high. Culms $1.4-4 \mathrm{~mm}$ diam. Leaves flat to strongly folded, bright mid-green; midrib \pm obvious abaxially, smooth; marginal prickles regularly spaced $(0.1-0.5(-1.6) \mathrm{mm}$ apart), short, $0.05-0.10 \mathrm{~mm}$ long, antrorse to erect, aculeate or papillate; leaf sheaths \pm smooth, shining, pinkish to purple-red-brown at base. Inflorescence compound, (5-)8-12 primary branches to $16 \mathrm{~cm}$ long; bracts 2-3 exceeding the inflorescence. Spikelets in loose clusters of $1.5-6 \mathrm{~cm}$ diam.; spikelets 8$40 \mathrm{~mm}$ long, $2.0-2.8 \mathrm{~mm}$ wide in side view, (6-)12-48-flowered; rachilla narrowly to broadly winged, wings $0.05-0.10 \mathrm{~mm}$ wide; glume spacing $1.3-2.0 \mathrm{~mm}$. Glumes narrow-ovate to narrow-elliptic, retuse to acute, with straight mucro $0.2-0.5 \mathrm{~mm}$ long, sides 2-4-nerved, stramineous to golden to red-brown, 2.0-3.2 mm long, margins narrow-membranous and not inrolled. Anthers $0.7-1.3 \mathrm{~mm}$ long. Nut very narrowelliptic to very narrow-obovate with acute apex, $1.8-2.5 \mathrm{~mm}$ long, $2 / 3-7 / 8$ as long as glume. Figure 23d-f.

Distribution: Most common in Central Australia, Barkly Tableland and Victoria River regions of the Northern Territory, extending to north-western Queensland ( $N$ of the Tropic of Capricorn), and scattered in central Western Australia. Figure 22c.

HABITAT: Sandy-loam to clayey soils; in seasonally wet situations (on banks of creeks and waterholes, in swamps).

The epithet is derived from the Latin commiscens, mixing or mingling, in recognition of the close relationship and past confusion between this taxon and subsp. betchei and C. dactylotes.

Specimens in other herbaria have often been labelled by me as ' $\mathrm{C}$. dactylotes (longglumed form)'.

The subspecies may grow with $C$. carinatus, $C$. holoschoenus and C. oxycarpus but is readily distinguished on spikelet and glume characters. In northwestern Queensland, it occasionally grows with C. dactylotes or C. fucosus. Two specimens, K. Wilson 5484 (Qld) and Latz 9522 (N.T.), show some approach to C. carinatus in their broader glumes, stouter habit and strongly septate-nodulose leaves. These may represent hybrids 

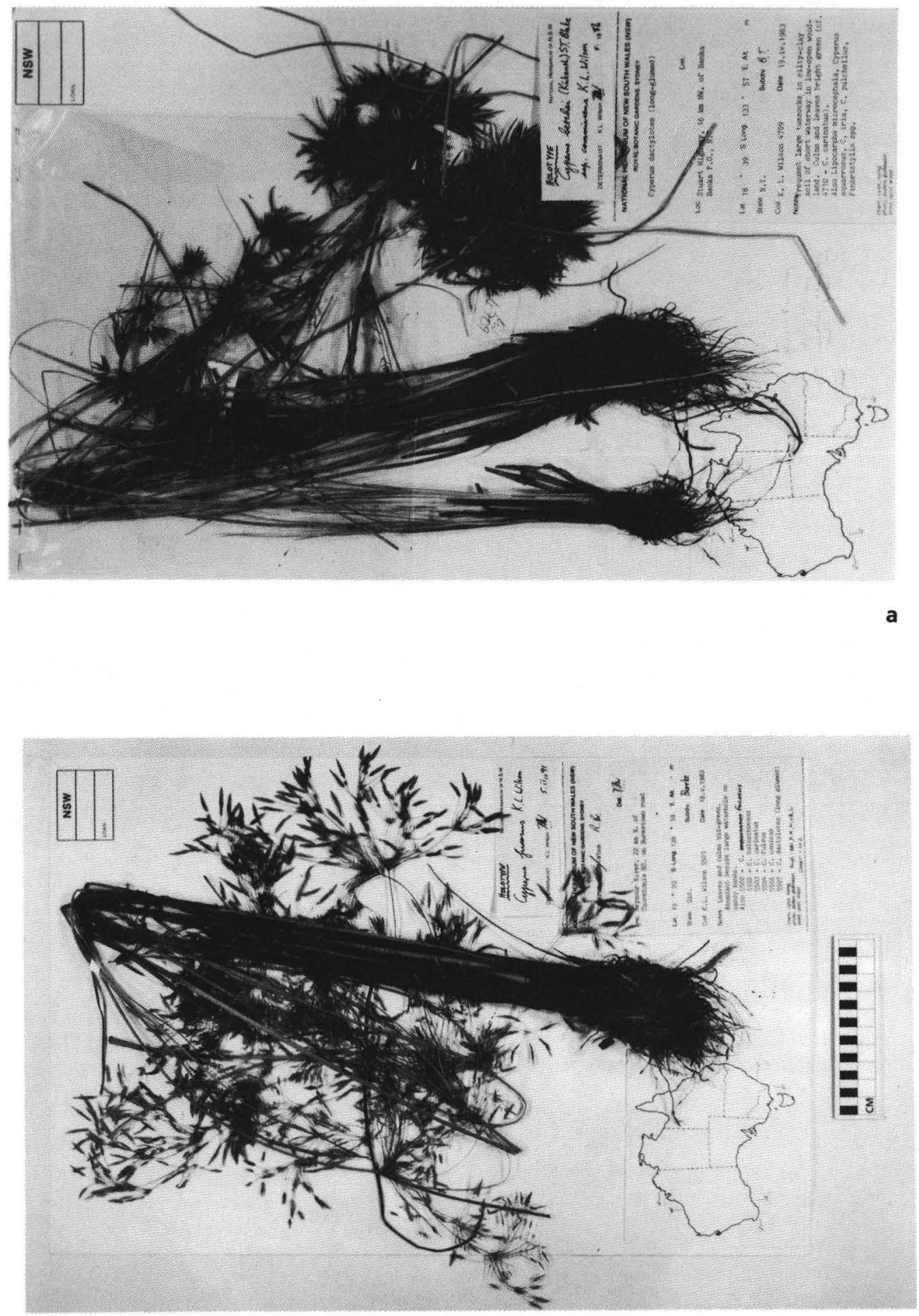

Figure 24. Holotype of a, C. betchei subsp. commiscens; b, C. fucosus. 
between these two species. The few specimens that I have seen from Western Australia have a slightly different facies but the differences seem insufficient to recognise any infraspecific taxon formally.

SELECTED SPECIMENS (58 examined): QUEENSLAND: Burke: Barkly Highway, $11 \mathrm{~km}$ SE of Buckley R., Wilson 5423, May 1983 (NSW, AD, BRI, NT); Leichhardt R., $8 \mathrm{~km} \mathrm{~S}$ of Mt Isa, Wilson 5439, May 1983 (NSW, BRI, DNA, K); Little Creek, 19 km NW of Riversleigh HS., Wilson 5543, May 1983 (NSW, BRI, DNA, PERTH). Gregory North: $22 \mathrm{~km} \mathrm{~N}$ of Wills Creek on Duchess-Mt Isa road, Wilson 5455, May 1983 (NSW, BRI). NORTHERN TERRITORY: Darwin and Gulf: Tanumbirini Creek, Cox River Station, Latz 7317, July 1977 (NSW ex NT). Victoria River: Buchanan Highway, 39 km E of Top Springs Roadhouse, Wilson 4730, Apr 1983 (NSW). Barkly Tableland: 43 miles [69 km] S Mallapunyah HS., Chippendale, Mar 1959 (NT 5560, AD, BRI, CANB, MEL, NSW, PERTH); Attack Creek, McD. Stuart, 1876 (K, BRI, MEL); Stuart Highway, $16 \mathrm{~km}$ NW of Banka Banka P.O., Wilson 4709, Apr 1983 (NSW, BRI, K). Central North: Frew R., 3 miles [5 km] ENE Epenarra HS., Latz 660, Mar 1970 (NT, BRI); Murray Downs Station, Latz 6915, May 1977 (K, NSW); 1.9 miles [3 km] E of Wycliffe Creek crossing, Nelson 690, Apr 1963 (NT, AD, BRI, CANB, MEL, NSW); Hanson R., c. 1 km WNW of Stuart Monument, Wilson 4660, Apr 1983 (NSW, AD, BRI, CANB, K, NT). Central South: pool at S end of Serpentine Gorge, Henshall 1946, Apr 1976 (NT). WeSTERN Australia: Mueller: Djaluwon Creek, near S end of Lake Gregory, George 15391, Apr 1979 (PERTH, CANB, NT). Fortescue: $20 \mathrm{~km}$ E of Balfour Downs HS., P. Wilson 10366, Aug 1971 (PERTH). Keartland: Rudall R., George 10712, May 1971 (PERTH, CANB). Ashburton: 75 miles [121 km] S of Mundiwindi, Burbidge 6076, May 1958 (CANB, BRI). Austin: Uramurdah Creek, Craven 5222, Apr 1978 (CANB).

\section{Cyperus dactylotes Benth.}

Bentham (1878: 273), p.p. max., excluding McDougall [sic] Stuart specimen; Bailey (1902: 1741); Domin (1915: 428, Figure 99), p.p.; Kükenthal (1935-36: 452), p.p.; Black (1943: 144), Black (1978: 261); Blake (1947a: 43); Wilson (1981a: 506), p.p.; Cunningham et al. (1981: 158).

TYPE: QUEENSLAND: Bowen Downs, Birch; lecto K (here designated); isolecto BRI, MEL.

C. clelandii J. Black (1924: 253); Black (1929: 676). TYPE: SOUTH Australia: Cordillo Downs, J.B. Cleland, 22 May 1924; holo AD 97413001.

[C. diphyllus auct. non Retz.: Bentham (1878: 279), p.p. (Gosse specimen)]

[C. gunnii auct. non Hook. f.: Ewart \& Davies (1917: 55), p.p. (Hill 298)]

More or less robust perennial, tufted, often forming large tussocks, 45-100 cm high, not viscid. Culms terete throughout or trigonous near the apex, smooth, $2.5-4.5 \mathrm{~mm}$ diam. Leaves flat or canaliculate or occasionally carinate, septate-nodulose, $\leq$ culms or occasionally shortly exceeding the culms, to $6.5 \mathrm{~mm}$ wide, mid-green; midrib occasionally obvious abaxially, smooth (rarely scabrous); marginal prickles sparse to dense, regularly spaced $(0.1-0.9 \mathrm{~mm}$ apart $)$, short, $0.05-0.10 \mathrm{~mm}$ long, antrorse, aculeate; leaf sheaths septate-nodulose, striate or smooth and shining, stramineous (may be pinkish brown at base), margins white-membranous with red spots or brown with age. Inflorescence compound to decompound, 4->15 primary branches to $14 \mathrm{~cm}$ long; bracts erect to spreading, usually septate-nodulose, (2-)3-5 at times nearly as long as the culms. Spikelets few to numerous in \pm loose, subdigitate, hemispherical to globose clusters of 1-3(-4) cm diam.; spikelets compressed, oblong, 5-12(-26) mm long, 1.2$2.2 \mathrm{~mm}$ wide in side view, 6-20(-46)-flowered; rachilla not thickened, not or narrowly winged, wings to $0.05 \mathrm{~mm}$ wide; glume spacing $0.9-1.3 \mathrm{~mm}$; spikelet falling as a unit, or rachilla persistent and glumes falling individually. Glumes narrow-ovate to elliptic, retuse to acute with straight mucro $<0.1-0.2 \mathrm{~mm}$ long, stramineous to golden-brown (rarely dull red-brown at maturity) with green midrib, $1.3-2.1 \mathrm{~mm}$ long, $0.5-0.7 \mathrm{~mm}$ wide, sides 2-3-nerved, margins \pm inrolled and membranous. Anthers $0.3-0.5 \mathrm{~mm}$ long 
excluding appendage $\leq 0.1 \mathrm{~mm}$ long. Nut trigonous, narrow-elliptic to narrow-obovate with acute to broad-acute apex, faces flat, yellow-brown to dark golden-brown, colliculate to foveate, glistening, 1.3-1.6 $\mathrm{mm}$ long, $3 / 4-7 / 8$ as long as glume, $0.4-0.5 \mathrm{~mm}$ diam., falling with glume. Figure $23 \mathrm{~g}-\mathrm{i}$.

DistribUTION: Widespread in central and western Queensland (occasional on the NE coast), Central Australia (Central North and South), Barkly Tableland, NE corner of South Australia and NW corner of New South Wales, occasional in the Kimberley and Pilbara regions of Western Australia. Figure 22d. Probst (1949) records C. dactylotes as a wool-alien in Kettwig in 1932; Ryves (1976) lists the species as a wool-alien at Blackmoor Fruit Farm, N Hants., England.

HABITAT: Sandy-loam to clayey soils; in at least seasonally wet situations (banks of creeks, borrow-pits and waterholes, floodways, gilgais, and roadside drains).

C. dactylotes is closely related to C. fucosus and C. betchei (q.v.). It is distinctive in its combination of robust habit and small, bright yellow to dark golden-brown glumes. It further differs from $C$. fucosus in the number of long inflorescence bracts, in the prickles on the leaf and bract margins, and in the glume apex, which is more acute in C. dactylotes and produced in a straight mucro. C. dactylotes is occasionally found growing with $C$. centralis (q.v.)., C. carinatus and C. holoschoenus but is readily distinguishable on spikelet and glume characters.

A minor mystery surrounds the specimens used by Bentham in describing $C$. dactylotes. Bentham's description is complete, implying that he saw at least some whole specimens ('leaves rather long, but only sent with very few specimens'). I have seen all the cited specimens (in K or MEL) and they consist only of inflorescences. The fate of any complete specimens is not known; Bentham, in the Concluding Preface to his Flora (1878), says that he had returned numerous consignments to Melbourne 'without a single loss' en route.

Selected SPECIMENS (117 examined): QueENSLAND: Cook: Bullock Creek, Correll, Oct 1969 (BRI 154642). Burke: Barkly Highway, $46 \mathrm{~km}$ SE of Camooweal, Wilson 5420, May 1983 (NSW, AD, BRI, DNA, H, K, P, UB). North Kennedy: Rita Island, 12 km S of Ayr, Sharpe 1566, June 1975 (BRI). South Kennedy: western side of Hannans Gap, Wilson $\mathcal{E}$ Sharpe 3584, May 1981 (NSW). Gregory North: Pigeon Creek, $50 \mathrm{~km}$ NW of Dajarra, Wilson 5476, May 1983 (NSW). Gregory South: Wilsons R. near Nocundra, Carolin 4310, Aug 1964 (SYD). Mitchell: Romulus Tableland, $50 \mathrm{~km}$ SE of Blackall, Beeston 1451, July 1975 (BRI). Leichhardt: Panorama Creek Overflow, Wilson et al. 3621, May 1981 (NSW, BRI). Maranoa: $5 \mathrm{~km} \mathrm{E}$ of Walumbilla, Wilson \& Sharpe 3415, Apr 1981 (NSW, BRI, H, K, L, P, UB, US). Warrego: $13 \mathrm{~km} \mathrm{~W}$ of Morven, Wilson et al. 3463, Apr 1981 (NSW, BRI, H, K, P). New South Wales: North Far Western Plains: Tero Creek Station, Martensz 4134, Dec 1968 (CANB, NSW). NORTHERN TerritorY: Victoria River: 70.5 miles [113 km] NE Tanami, Chippendale 5710, Apr 1959 (NT, AD, BRI, MEL, NSW). Barkly Tableland: Lancewood Creek, Latz 1656, July 1971 (NT, CANB). Central North: Boomerang Waterhole, Lander R., Chippendale 4782, July 1958 (NT, AD, BRI, MEL, NSW). Central South: Reedy Rock Hole, George Gill Range, Beauglehole 26618, July 1968 (NSW). SoutH Australia: Lake Eyre: Bradys Waterhole, Cordillo Downs, Basedow 57, Oct 1919 (K, NSW). Western Australia: Gardner: King Edward R., Mitchell Plateau road, Beauglehole 51918, June 1976 (NT). Dampier: Fitzroy River at Noonkanbah, Gardner 7102, May 1944 (PERTH). Hall: East branch Wolf Creek, c. $60 \mathrm{~km}$ S Halls Creek, Beauglehole \& Carr 47336, July 1974 (NSW). Mueller: Wolf Creek, c. 3 km WSW of crater, George 15348, Apr 1979 (PERTH, CANB, NT). Fortescue: Joffre Falls, Hamersley Range National Park, Beauglehole \& Carr 48758, Aug 1974 (NSW, NT). 


\section{Cyperus fucosus K.L. Wilson, sp. nov.}

A C. dactyloti colore glumarum, habitu graciliore, bracteis involucralibus longis 1-2, apice glumae obtusiore, differt.

TYPE: QuEENSLAND: Burke: Seymour River, $22 \mathrm{~km} \mathrm{~N}$ of Thorntonia HS. on Burketown road, K.L. Wilson 5501, 18 May 1983; holo NSW; iso BRI, H, K, L, P, UB. Figure 24b.

[C. carinatus auct. non R. Br.: Bentham (1878: 274), p.p. min.; Bailey (1902: 1742), p.p.; Ewart \& Davies (1917: 55), p.p. (Gulliver collections)]

Tall but not very robust perennial, tufted, $65-90 \mathrm{~cm}$ high, not viscid. Culms terete, smooth, 1-3.3 mm diam. Leaves canaliculate or carinate, somewhat septate-nodulose, about as long as culms, to $4 \mathrm{~mm}$ wide, bright yellow-green to mid-green; midrib occasionally obvious abaxially, smooth (rarely scabrous); marginal prickles very sparse to sparse (often absent below), irregularly spaced (0.9-2.0 mm apart), short, c. 0.05 $\mathrm{mm}$ long, antrorse to erect, aculeate; leaf sheaths mostly not septate-nodulose, dull, striate, stramineous above, red-brown to purplish below, margins white-membranous with red spots or brown with age. Inflorescence small-compound to decompound, 4->15 primary branches to $14 \mathrm{~cm}$ long; bracts erect to spreading, usually septate-nodulose, 1-2 exceeding inflorescence. Spikelets few (3-10) in loose hemispherical clusters of 1-3.5 cm diam.; spikelets compressed, oblong, 7-26 mm long, 1.7$2.5 \mathrm{~mm}$ wide in side view, 8-26(-40)-flowered; rachilla not thickened, not or narrowly winged, wings to $0.05 \mathrm{~mm}$ wide; glume spacing $0.9-1.3 \mathrm{~mm}$; spikelet with rachilla persistent and glumes falling individually. Glumes elliptic to narrow-ovate, retuse to broad-acute with straight or excurved mucro $\leq 0.1 \mathrm{~mm}$ long, usually dull red-brown or occasionally stramineous, with green midrib, $1.8-2.8 \mathrm{~mm}$ long, $0.4-0.5 \mathrm{~mm}$ wide, sides 2-3-nerved, margins \pm inrolled and membranous. Anthers $0.3-0.7 \mathrm{~mm}$ long excluding appendage $\leq 0.1 \mathrm{~mm}$ long. Nut trigonous, very narrow- to narrow-elliptic with acute to acuminate apex, faces flat, pale yellow-brown to dark golden-brown, tuberculate to foveate, glistening, $1.4-1.7 \mathrm{~mm}$ long, c. 7/8 as long as glume, $0.4-0.5 \mathrm{~mm}$ diam., falling with glume. Figure 23j-1.

Distribution: Around the Gulf of Carpentaria in the Northern Territory and Queensland. Figure 22e.

НАВітАт: Sandy-loam to clayey soils; on seasonally wet sites (beds and banks of creeks, waterholes, lagoons and floodways).

The epithet refers to the characteristic colour of the glumes and lower leaf sheaths, as well as to the confusion of this taxon with $C$. angustatus and $C$. dactylotes. It comes from the Latin fucosus, a purplish red colour (from the alga Fucus) and also, secondarily, painted or disguised.

The species is closely related to $C$. dactylotes, differing from that in glume colour (never bright yellow), the retuse to broad-acute glume apex, the fewer involucral bracts, the irregular prickles on the leaf margins, the more slender habit, and the striate leaf sheaths (which are red-brown to purplish towards the base). These species are not sympatric so far as known, although their distributions come very close to overlapping.

At times, C. fucosus has been confused in the herbarium with C. angustatus but can be readily distinguished by its tufted habit, its lesser glume spacing, its nut shape and size, and its glumes, whose membranous margins tend to inroll and hold the nut. It occasionally grows with $C$. carinatus and C. holoschoenus, which both tend to be more robust than it and are readily distinguished on spikelet features. 
SPECIMENS EXAMINED: QueENSLAND: Burke: Glenore near Normanton, Blake 9119, May 1935 (BRI, MEL); 14 miles [22 km] NW of Corinda on Westmoreland road, Carolin 9139, May 1974 (SYD, K, NSW); towards Croydon from Esmeralda (13 miles [21 km]), Blake 19608, July 1954 (BRI); Nicholson River area, Henshall 249, June 1974 (NT, BRI); 38 miles [61 km] N of Thorntonia Station, Perry 1084, May 1948 (CANB, BRI, K); Seymour R., $22 \mathrm{~km} \mathrm{~N}$ of Thorntonia HS., Wilson 5500, May 1983 (NSW, BRI, DNA, H, K, L, P, PERTH, UB), Wilson 5501, May 1983 (NSW); Little Creek, 19 km NW of Riversleigh HS., Wilson 5544, May 1983 (NSW, BRI, DNA, K, P, PERTH); Norman River, Gulliver 29, (BRI 199666); between the Norman and Gilbert Rivers, Gulliver 41, 1874 (MEL 92157). NortherN TeRrITORY: Darwin and Gulf: Nutwood Downs Station, Blake 17599, May 1947 (BRI); Cox River Station, Latz 7233, July 1977 (NT, BRI, NSW).

\section{Cyperus gunnii J.D. Hook.}

Hooker (1858: 80, pl. 140A)

Tall but relatively slender perennial, tufted, forming big tussocks, deep-rooted, 80-180 $\mathrm{cm}$ high, not viscid. Culms triquetrous to terete, smooth or occasionally slightly scabrous, often septate-nodulose, $1.7-4 \mathrm{~mm}$ diam. Leaves carinate, occasionally flat or canaliculate, strongly septate-nodulose, $\geq$ culms, to $7 \mathrm{~mm}$ wide, yellow-green; midrib usually obvious, usually scabrous; marginal prickles dense to sparse, \pm regularly spaced (0.1-1.4 mm apart), long to short, $0.05-0.15 \mathrm{~mm}$ long, strongly and coarsely antrorse aculeate (often worn-down on mature leaves and then easier to feel than to see); leaf sheaths septate-nodulose, \pm smooth and shining, orange-brown to grey-brown, occasionally stramineous above, margins near base narrow-membranous and red-brown. Inflorescence simple to compound, 5-12 primary branches to $12 \mathrm{~cm}$ long; bracts \pm erect, septate-nodulose, 2-3 much exceeding the inflorescence. Spikelets numerous in \pm dense, spicate to subdigitate, hemispherical to globose clusters of $0.7-3 \mathrm{~cm}$ diam.; spikelets compressed, oblong to narrow-ovate, $6-12(-20) \mathrm{mm}$ long, $1.0-2.5 \mathrm{~mm}$ wide in side view, 4-12(-28)-flowered; rachilla not thickened, narrowly or occasionally broadly winged, wings to $0.2 \mathrm{~mm}$ wide; glume spacing $1.2-2.2 \mathrm{~mm}$; spikelet falling as a unit, or rachilla persistent and glumes falling individually. Glumes narrow-elliptic, broadacute with straight mucro $<0.1-0.2 \mathrm{~mm}$ long, stramineous to red-brown, with green midrib, 2.0-2.7(-3.2) mm long, 0.5-0.9 mm wide, sides 2-4-nerved, margins \pm inrolled and narrow-membranous. Anthers $0.7-1.5 \mathrm{~mm}$ long excluding appendage $<0.1 \mathrm{~mm}$ long. Nut trigonous, narrow-elliptic to very narrow-elliptic with acute to acuminate apex, faces flat or slightly convex, pale yellow-brown to dark brown, colliculate to smooth and reticulate-areolate, shining, 1.5-2.2 mm long, c. $3 / 4-7 / 8$ as long as glume, 0.3-0.7 mm diam., falling with glume. Figure 25a-f.

Distribution: Along the Queensland east coast $S$ from Cairns and inland to the Darling Downs, extending through the eastern half of New South Wales to Victoria, Tasmania and the South-eastern and Southern Lofty regions of South Australia. Figure 22f. Recorded once in New Zealand, apparently naturalised. Ryves (1976) records this species as a wool-alien at Blackmoor Fruit Farm, $N$ Hants., England.

Ewart (1931) gives the common name of this species as 'Flecked Leaf-rush', which seems contrived and inappropriate. Willis $(1962,1970)$ gives this name as an alternative, preferring the equally unattractive 'Flecked Flat-sedge'.

Bentham (1878) cited a specimen, 'Cunningham, In the interior' (K!), under this species but it is actually C. victoriensis C.B. Clarke. A specimen 'Birch, Barcoo Downs' cited by Domin (1915) and Kükenthal (1935-36) as C. gunnii is probably also C. victoriensis (or perhaps the closely related species $C$. bifax).

The two subspecies of C. gunnii are allopatric (see Figure 51). Morphologically, they can be distinguished as follows: 
1 Spikelets deep red-brown, 1.5-2.5 mm wide in side view, 6-12(-24)-flowered, forming dense clusters; nut diam. $0.5-0.7 \mathrm{~mm}$; nut apex acute; leaves with sparse to dense marginal prickles, $0.1-1.4 \mathrm{~mm}$ apart

a. subsp. gunnii

1 Spikelets stramineous or pallid red-brown, $1.0-1.5 \mathrm{~mm}$ wide, 4-28-flowered, forming loose clusters; nut more slender, $0.3-0.4 \mathrm{~mm}$ diam., with long-acute to acuminate apex; leaves with dense marginal prickles, $0.1-0.5 \mathrm{~mm}$ apart

\section{b. subsp. novae-hollandiae}
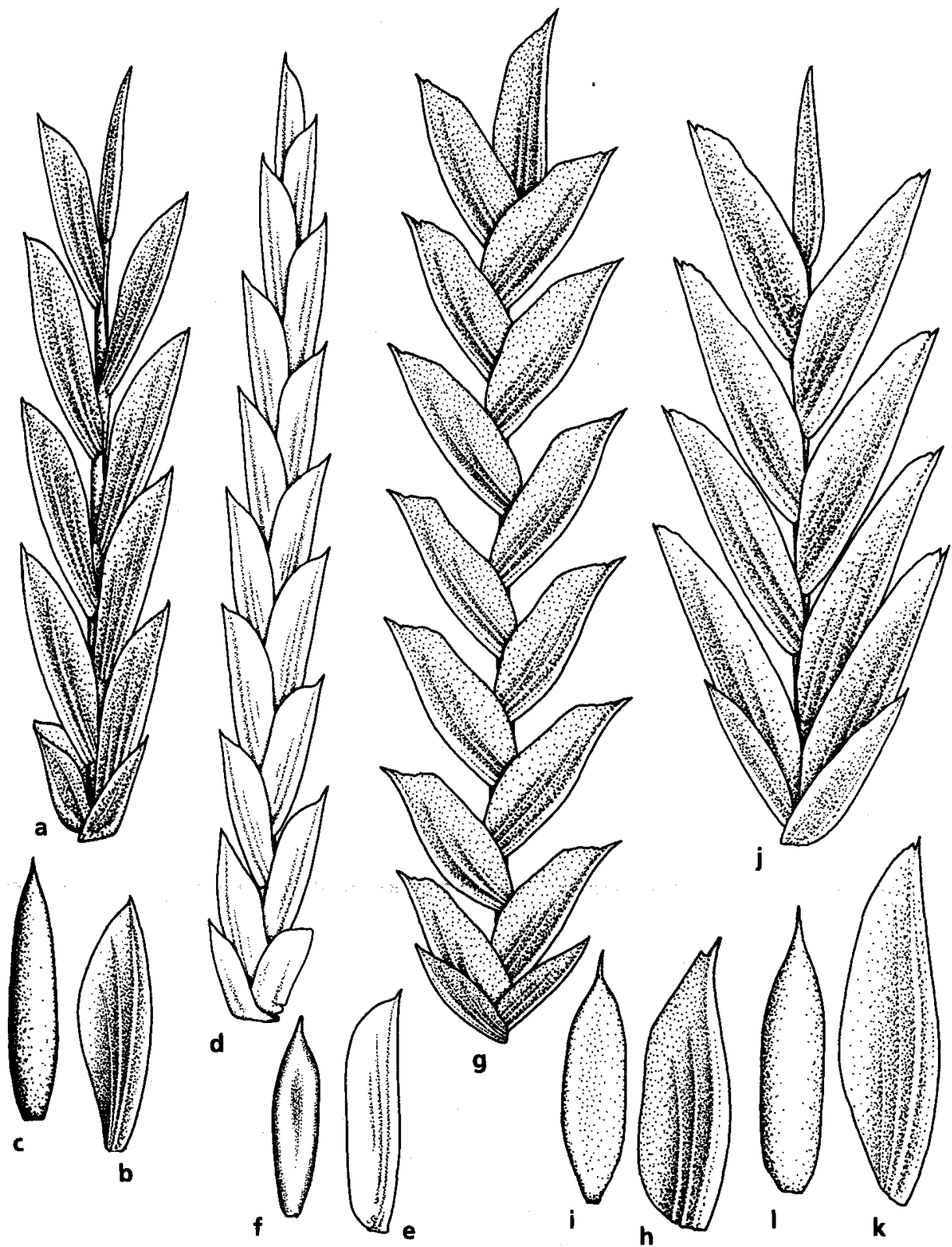

Figure 25. Spikelet details. C. gunnii subsp. gunnii: a, spikelet; b, glume; c, nut. C. gunnii subsp. novae-hollandiae: $\mathbf{d}$, spikelet; $\mathbf{e}$, glume; $\mathbf{f}$, nut. C. alterniflorus: $\mathbf{g}$, spikelet; $\mathbf{h}$, glume; $\mathbf{i}$, nut. C. lhotskyanus: $\mathbf{j}$, spikelet; $\mathbf{k}$, glume; $\mathbf{1}$, nut. a-c from NSW 65255; d-f Blake 14481; g-i Wilson 2675; j-1 NSW 22678. a, d, g, j X 11; b, c, e, f, h, i, k, $1 \times 14$. 
21a. C. gunnii subsp. gunnii

Cyperus gunnii J.D. Hooker (1858: 80, pl. 140A); Bentham (1878: 283), p.p.; Bailey (1902: 1747), p.p.; Rodway (1903: 238); Black (1929: 90), (1943: 144), (1978: 263, Figure 229), p.p.; Ewart (1931: 214); Kükenthal (1935-36: 449), p.p.; Willis (1962: 222), (1970: 222); Burbidge \& Gray (1970: 79); Healy \& Edgar (1980: 187); Cunningham et al. (1981: 161); Beadle et al. (1982: 602, 606); Wilson (1987: 1128, Figure 482E); Sharpe (1989: 326). C. lucidus R. Br. var. gunnii (Hook. f.) Moore \& Betche (1893: 449). Mariscus gunnii (Hook. f.) C.B. Clarke (1908: 18). Mariscus gunnii var. typicus Domin (1915: 442), p.p. max.

TYPe: TASMANIA: Penquite, near Launceston, Gunn 1403; holo K; iso BRI, HO, NSW.

[C. decompositus auct. non R. Br.: Boeckeler (1870: 333), as C. compositus, sphalm.]

[C. nodulosus F. Muell. ex Bentham (1878: 283), nom. nud.]

[C. lucidus auct. non R. Br.: Mueller (1874: 270), p.p.; Mueller (1875: 53), p.p.]

Culms trigonous to terete. Leaves to $6.5 \mathrm{~mm}$ wide; marginal prickles sparse to dense (0.1-1.4 $\mathrm{mm}$ apart), short, $0.05-0.10 \mathrm{~mm}$ long, very strongly aculeate. Inflorescence simple to compound, 5-8 primary branches to $12 \mathrm{~cm}$ long. Spikelets numerous in dense, subdigitate, \pm globose clusters of $0.7-2(-3) \mathrm{cm}$ diam.; spikelets $1.5-2.5 \mathrm{~mm}$ wide in side view, 6-12(-24)-flowered; rachilla narrowly to broadly winged, wings $0.05-0.10(-0.2)$ $\mathrm{mm}$ wide; glume spacing 1.2-2.2 $\mathrm{mm}$. Glumes red-brown to dark red-brown (rarely stramineous), 2.0-2.7(-3.2) $\mathrm{mm}$ long, $0.5-0.9 \mathrm{~mm}$ wide. Anthers $0.8-1.5 \mathrm{~mm}$ long. Nut 1.5-2.2 mm long, c. $3 / 4$ as long as the glume, $0.5-0.7 \mathrm{~mm}$ diam., apex acute. Figure $25 \mathrm{a}-\mathrm{c}$.

DISTRIBUTION: South-eastern Queensland to Tasmania, and the South-eastern region of South Australia, with outlying occurrences in the Southern Lofties of South Australia and on the Murray River near Mildura. Also one record from the North Island of New Zealand (considered to be an introduction by Healy \& Edgar (1980)). Figure 22f.

HABITAT: Sandy to loam soils; beside semi-permanent water (creek banks, floodways, swamps, roadside drains).

Subsp. gunnii differs from subsp. novae-hollandiae in its broader and often fewerflowered spikelets that are nearly always red-brown (unlike the often pallid spikelets of novae-hollandiae) and that form much denser clusters. Its glumes are usually broader than in novae-hollandiae and its nut is of greater diameter. So far as seen, subsp. gunnii differs in habit from subsp. novae-hollandiae, forming more spreading tussocks and therefore giving the appearance of being a much shorter plant. In both subspecies, the inflorescence bracts are very long (up to $65 \mathrm{~cm}$ long) but they are relatively much longer in subsp. gunnii where they may nearly equal the length of the culms.

Subsp. gunnii occasionally grows with or near C. lhotskyanus. The two taxa can be distinguished readily in the field by the tussock-forming habit of subsp. gunnii and the shortly rhizomatous habit of C. lhotskyanus. Subsp. gunnii is more robust in general habit but is smaller in many of its floral parts (spikelet width, glume length and width, mucro length, nut diameter), has more regularly antrorsely aculeate marginal prickles on the leaves, and has much longer inflorescence bracts. There is also some similarity to C. alterniflorus (q.v.).

SeleCted SPECIMENS (217 examined): QueENSLAND: Moreton: at Durundur Lagoon, Leichhardt, Oct 1843 (MEL). Darling Downs: Crawlers Creek, c. 7 km SW of Cecil Plains, Wilson 1379, Oct 1975 (NSW, BRI). Maranoa: Coffin Gully, $0.5 \mathrm{~km} \mathrm{~N}$ of Ogilvie road junction, Wilson et al. 3429, Apr 1981 (NSW). NeW SoutH WALEs: North Coast: near Branxton, Goode 254, Dec 1954 (BM, NSW), Central Coast: $1 \mathrm{~km}$ S of Leppington, Johnson $\mathcal{E}$ Edgar 7251, Oct 1971 (CHR, NSW). South Coast: Boydtown turnoff from Princes Highway, Wilson 2251, Feb 1979 (NSW, BRI, CHR, K, MEL, P). 
Northern Tablelands: Parlour Mountains, vicinity Boorolong, Gray 3891, Jan 1956 (CANB, NSW). Central Tablelands: Beaconsfield-Burraga, Campbells R., Carolin 928, Mar 1959 (SYD). Southern Tablelands: Delegate Common, Forsyth, Jan 1910 (NSW 122277, BRI, K, MEL). Central Western Slopes: Grenfell-Gooloogong road, just N of Bald Hills turnoff, Wilson 4439, Apr 1982 (NSW, P). South Western Slopes: Murray R. on Khancoban-Corryong road, Wilson 2054, Feb 1979 (NSW, K, MEL, P). North Western Plains: Bebo State Forest, E of Yetman, Coveny \& P. Wilson 11688, Nov 1983 (NSW, BRI). South Western Plains: Humbug (Euglo) Creek c. $5.5 \mathrm{~km}$ direct SW of Winnunga, Wilson 5626, Nov 1983 (NSW, BRI, H, K, L, NY, P, UB). VICTORIA: A: Kings Billabong, pumping station at Psyche Bend, Johnson \& Wilson 7977, Feb 1975 (NSW, MEL, P). D: Mathers Creek Reserve, Balmoral, Beauglehole 50348, Oct 1975 (NSW). E: Darlots Creek Sanctuary, Etterick, Melville et al. 1674, Oct 1952 (K, MEL, NSW). H: Kooyoora-Melville Caves State Park, Beauglehole 69458, Oct 1981 (NSW). J: Fyans Creek in Halls Gap Valley, Symon 1867, Nov 1961 (AD). K: Hopkins River, Framlingham Forest, Wilson 6806, Mar 1986 (NSW). L: Barmah State Forest, 30 km NNW of Numurkah P.O., Beauglehole 64289, June 1979 (MEL, NSW). N: c. 3 km SSE of Lal Lal, Beauglehole 61771, Nov 1978 (MEL, NSW). P: $1.4 \mathrm{~km} \mathrm{~W}$ along Gum Flats Road from Forest Road, N of Anglesea, Wilson 6827, Mar 1986 (NSW). R: Yackandandah, Meebold 21664, Nov 1936 (NSW). U: 7 km SSE of Walwa P.O., Beauglehole 68485, May 1980 (MEL, NSW). V: $24.5 \mathrm{~km}$ S of Colac Colac on Omeo road, Wilson 2066, Feb 1979 (NSW, CHR, K, MEL, P). Z: c. $4 \mathrm{~km}$ from Genoa on Mallacoota road, Wilson 2206, Feb 1979 (NSW, CHR, K, MEL, P). TASMANia: Westbury, Curtis, Feb 1948 (HO); bank of S Esk River at Perth, Curtis and Cameron, Feb 1979 (HO); Ouse, Mason 13204A, Jan 1977 (HO); Lake House near Cressy, Perry, Apr 1947 (CANB); Liffey, Rodway 164, Jan 1931 (CANB, K); Meander River flats, Somerville, Jan 1959 (HO). SOUTH AusTRALIA: Northern Lofty: S Para R., crossing at border of Para Wirra National Park, Spooner 1220, Jan 1971 (AD). Southern Lofty: Millbrook Reservoir, c. 20 km NE of Adelaide, Symon 2071, Mar 1962 (AD). Murray: Tailem Bend, Ising, Feb 1926 (AD 966150123). South-eastern: $2.5 \mathrm{~km}$ SE of Glencoe on Mt Gambier road, Wilson 6106, Feb 1985 (NSW). NEW ZeALAND: North Island: Okaihau, Bay of Islands Co., Esler CHR 284143, Nov 1970 (CHR).

\section{1b. C. gunnii subsp. novae-hollandiae (Boeck.) K.L. Wilson, comb. et stat. nov.}

BAsIONYM: Cyperus novae-hollandiae Boeckeler (1870: 344), as Novae Hollandiae"; Boeckeler (1875: 86); Mueller (1875: 54); Bentham (1878: 282); Bailey (1902: 1746).

Mariscus gunnii var. novae-hollandiae (Boeck.) Domin (1915: 443, as 'Novae-Hollandi$\mathrm{ae}^{\prime}$ ). C. gunnii var. novae-hollandiae (Boeck.) Kükenthal (1935-36: 450). TYPE: QUEENSLAND: North Kennedy: Rockingham Bay, Dallachy [given in protologue as 'Rockingham Bay, F. Mueller']; lecto MEL (here designated); isolecto K, MEL, ?P.

$\mathrm{Culms}$ triquetrous to trigonous. Leaves to $7 \mathrm{~mm}$ wide; marginal prickles dense $(0.1-0.5$ $\mathrm{mm}$ apart), long to short, $0.10-0.15 \mathrm{~mm}$ long, strongly aculeate. Inflorescence smallcompound to compound, 5-12 primary branches to $12 \mathrm{~cm}$ long. Spikelets c. 10 in spicate to subdigitate, \pm loose, hemispherical to globose clusters of $1.2-3 \mathrm{~cm}$ diam.; spikelets $1.0-1.5 \mathrm{~mm}$ wide in side view, 4-24-flowered; rachilla narrowly winged, wings c. $0.05 \mathrm{~mm}$ wide; glume spacing $1.5-2.0 \mathrm{~mm}$. Glumes stramineous to red-brown, $2.1-2.7$ $\mathrm{mm}$ long, $0.5-0.6 \mathrm{~mm}$ wide. Anthers $0.7-1.3 \mathrm{~mm}$ long. Nut $1.6-2.1 \mathrm{~mm}$ long, c. $7 / 8$ as long as glume, $0.3-0.4 \mathrm{~mm}$ diam., apex long-acute to acuminate. Figure $25 \mathrm{~d}-\mathrm{f}$.

DistRIBUTION: Scattered along the eastern coast of Queensland, from near Cairns to Bundaberg. Figure 22f.

HABITAT: Margins of coastal swamps, often with Melaleuca quinquenervia, in water to $0.5 \mathrm{~m}$ deep for at least part of the year. Dovey (1935) describes the species in the Bottle Creek area ( $\mathrm{N}$ of Bundaberg) as 'not common, around clay waterholes in gumtopped Box [Eucalyptus moluccana] country on slate with indifferent drainage'.

Despite the bombing of B during World War II, at least some apparently original sheets of Boeckeler's herbarium still exist there. However, no relevant type material of this taxon has been located there. 
SeleCted SPECIMENS (27 examined): QueENSLAND: Cook: Innisfail, Blake 14481, Nov 1941 (BRI, NT), Flecker 7733, Dec 1941 (AD); Black Mountain road, near Kuranda, Brass 33745, Jan 1968 (BRI); Biboohra via Cairns, Wallon, Dec 1930 (BRI 187341). North Kennedy: $9.5 \mathrm{~km}$ E of Tully, Boyland 563, Nov 1967 (BRI, K); 4 km E of Proserpine, Byrnes \& Clarkson 3886, Apr 1978 (BRI); 9 km S of Ingham just W of Bruce Highway, Lazarides 8102, July 1976 (BRI,CANB); Allingham, ESE of Ingham, Moriarty 1573, Jan 1974 (BRI); Goorganga Plains, c. $7 \mathrm{~km} \mathrm{~S}$ of Lethebrook Creek on Bruce Highway, Russell 520, Sep 1978 (BRI); Cromarty, White 8852, Mar 1933 (BRI). Port Curtis: Rockhampton, Dietrich 640 (B), Dietrich 642 (BRI, K, L, MEL), Thozet, 1873 (BRI 166097, K, MEL); Rosedale area, Dovey 711, Dec 1935 (BRI); Eulalah Creek, c. 5 km NW of Wartburg, Sharpe \& Elsol 2684, Mar 1981 (NSW); near Wartburg on N side of Baffle Creek, Wilson \& Sharpe 3789, 3790, May 1981 (NSW).

22. Cyperus alterniflorus $R . B r$.

Brown (1810: 216); Poiret (1817: 188); Sprengel (1824: 227); Kunth (1837: 112); Steudel (1854: 54), as 'alternifolius'; Bentham (1878: 275), p.p. max.; Tate (1890: 181), p.p.; Bailey (1902: 1742), p.p.; Black (1922: 89), p.p.; Kükenthal (1935-36: 455), ?p.p.; Blackall \& Grieve (1954: 50); Cunningham et al. (1981: 156); non Schweinitz (1824). Mariscus alterniflorus (R. Br.) C.B. Clarke (1908: 18); Domin (1915: 441).

TYPE: QueENSLAND: Shoalwater Bay, East Coast, R. Brown (Bennett 5898); holo BM.

C. pictus Steudel (1854: 43); non Tenore (1824-29). TYPE: WESTERN Australia: J. Drummond coll. III $n$. 335; holo P; iso, E, G, K, MEL, TCD.

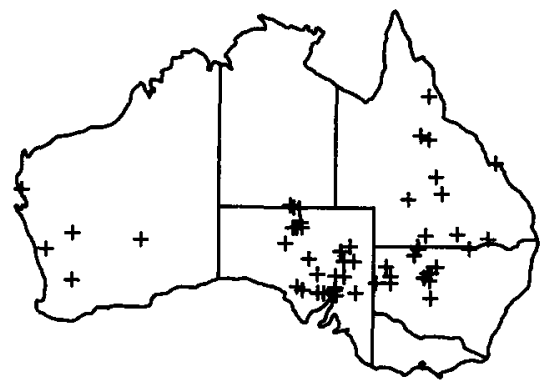

a

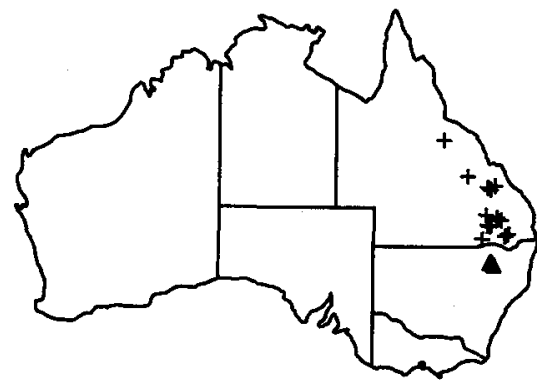

c

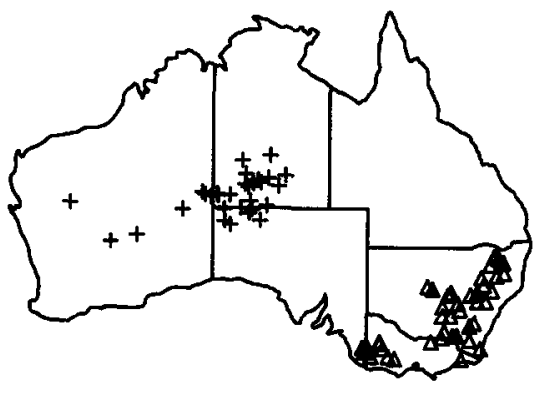

b $\subset$

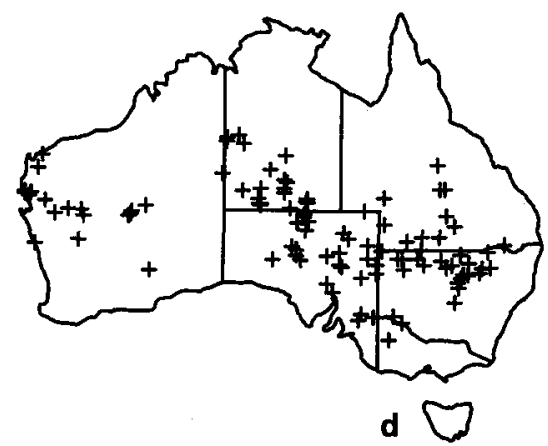

Figure 26. Distribution of: a, C. alterniflorus; b, C. lhotskyanus (open triangles) and C. centralis (crosses); c, C. secubans (open triangles) and C. isabellinus (crosses); d, C. rigidellus. 
C. clarus S.T. Blake (1940: 44), p.p. min. (Goyinga Mountains and South Australian specimens).

[C. fulvus auct. non R. Br.: Bentham (1878: 274), p.p. min. (Victorian Expedition, Gojinga [sic] Mountains)]

[C. gunnii auct. non J. D. Hook: Kükenthal (1935-36: 449), p.p. min. (Koch 391, Mt Lyndhurst); Black (1978: 263), p.p.]

[C. rutilans auct. non (C.B. Clarke) Maiden \& Betche: Kükenthal (1935-36: 455), p.p. min. (Koch 391, Mt Lyndhurst); Blake (1943: 53), p.p.; Black (1943: 145), p.p., (1978: 267), p.p.]

Robust perennial, tufted, forming big tușsocks (may be shortly rhizomatous), deeprooted, 30-150 cm high, often viscid near base. Culms triquetrous (to trigonous), smooth or scabrous at the apex, $2.0-5 \mathrm{~mm}$ diam. Leaves strongly folded to carinate, strongly septate-nodulose, $\geq$ culms, to $12 \mathrm{~mm}$ wide, yellow-green; midrib obvious abaxially and scabrous; marginal prickles dense or more rarely sparse, regularly spaced $(0.05-$ $0.9 \mathrm{~mm}$ apart), long, 0.1-0.2 mm long, often coarse, antrorse, aculeate (less commonly irregularly short-papillate); leaf sheaths septate-nodulose (less obvious in smaller plants), smooth above, striate and/or fibrous below, mostly not shining, red-brown or red-purple (especially when young) to grey-brown. Inflorescence compound to decompound, occasionally small-compound or simple, 3-8 primary branches to 15 $\mathrm{cm}$ long; bracts erect to spreading, 2-4 much exceeding the inflorescence. Spikelets 6numerous in spicate to subdigitate, \pm dense hemispherical to globose clusters of $1-5$ $\mathrm{cm}$ diam.; spikelets compressed, oblong to narrow-ovate, $5-17(-35) \mathrm{mm}$ long, $1.8-4.0$ $\mathrm{mm}$ wide in side view, 6-18(-48)-flowered, occasionally viscid; rachilla not thickened, not to broadly winged, wings to $0.1 \mathrm{~mm}$ wide; glume spacing $1.0-1.9 \mathrm{~mm}$; spikelet falling as a unit, or rachilla persistent and glumes falling individually. Glumes broadelliptic to elliptic, broad-acute to obtuse, with mucro $<0.1-0.4 \mathrm{~mm}$ long and somewhat excurved, golden-brown to red-brown with a green midrib, 2.0-3.5 mm long, 0.6-1.2 mm wide, sides (2-)3-4-nerved, margins \pm inrolled and very narrow-membranous. Anthers $1.1-1.8 \mathrm{~mm}$ long excluding appendage $50.1 \mathrm{~mm}$ long. Nut trigonous, narrow-elliptic to narrow-obovate with broad-acute apex, faces flat, pale red-brown to dark brown, tuberculate, glistening to dull, 1.6-2.3 mm long, c. $3 / 4$ as long as glume, $0.5-0.7 \mathrm{~mm}$ diam., falling with glume. Figure $25 \mathrm{~g}-\mathrm{i}$.

DistRIBUTION: From near Irvinebank (North Kennedy region, Queensland) southwest through western New South Wales to the Flinders and Gawler Ranges of South Australia; a few scattered records in southern Western Australia. Figure 26a.

HABITAT: Sandy to clay-loam soils; in at least seasonally wet sites (floodways, stream banks, rocky gullies).

Robert Brown labelled the type of $C$. alterniflorus as having been collected by him at Shoalwater Bay (north of present-day Rockhampton). This is, indeed, the only likely landing place for him to have collected this otherwise inland species. The relatively dry coastal belt around Rockhampton has many such species (Johnson 1964). This species has not been re-collected there, but that may be due to difficulty of access to army land, as that area is now. Comparison of Peter Good's diary (Edwards 1981) and Flinders' published account and charts (1814) suggests that the specimen was probably collected on the western side of Shoalwater Bay, either towards the Normanby Range or Pine Mount. Good's diary mentions that their party (including Brown) 'fell in with a Brook ... full of Stones' during their walk 'towards some high hills' [probably the Normanby Range] and that they found 'plenty of fresh water in pools and Creeks' on their way to Pine Mount. Both of these habitats would be suitable for this species. 
C. pictus was described by Steudel from Drummond's specimen 'Third Collection No. $335^{\prime}$, collected at the south-western extreme of the distribution of $C$. alterniflorus. Erickson (1969) states that Drummond's Third Collection comprised 14 sets of 350 specimens collected from 'N and $\mathrm{E}$ of Bolgart, K.G.S. [King George Sound], Stirling Ra., Porongorups, C. Riche and Mt Manypeaks'. Of those localities, N and E of Bolgart' is the most likely for No. 335 .

Kükenthal (1935-36: 455) cites a specimen 'Vasse River, Lindley' under C. alterniflorus. I have not seen the specimen but it is likely to be $C$. congestus Vahl rather than this species. There is a specimen 'Vasse River, Molloy' in CGE that is C. congestus but it had not been previously determined as C. alterniflorus.

C. alterniflorus is morphologically close to C. gunnii and C. lhotskyanus and has frequently been mis-identified as those species. It can be distinguished from C. gunnii by its coarser habit and generally larger parts. Its glumes are relatively broader than in C. gunnii and the mucro is generally longer. It can be distinguished from C. lhotskyanus by its generally taller and coarser tufted habit and lack of rhizomes, its leaf bases, which are red-brown to grey-brown with age and tend to become stout and fibrous with age (never pinkish and papery textured as in C. lhotskyanus), and its regularly and closely antrorsely aculeate leaf marginal prickles. It also shows similarities to C. centralis (q.v.).

The species is widely distributed in terms of geography and environmental conditions and, as one might expect, varies morphologically over its range. Deciding on the status of regional variants is made difficult by the shortage of mature specimens in herbaria: about $90 \%$ of the specimens examined had only immature flowers. Specimens from the north-east extreme of the distribution (including the type specimen) appear more slender, and the spikelets look more open with small glumes (1.9-2.6 mm long, $0.6-0.8(-1.0) \mathrm{mm}$ wide in side view). These specimens always have a short glume mucro ( $\leq 0.1 \mathrm{~mm}$ long), and leaf marginal prickles are sparser and more irregular. However, prickles can vary on the one leaf from long-aculeate near the apex to shorter and blunter towards the base (e.g. Wilson 1674,3576), which could be an effect of weathering or of differential deposition of silica. The specimen Correll T126, at the north-eastern extreme of the species' range, differs from other eastern collections in being relatively slender, with leaves not strongly septate-nodulose, bases striate and not deeply rooted, and glumes more slender with finer nerves on the sides.

Specimens from the western limit of distribution of the species in South Australia and Western Australia generally differ from the typical specimens of the eastern part of the distribution in having marginal prickles on the leaves that are shorter, erect, papillate or blunt-aculeate and very irregularly spaced. They also tend to have very yellow to golden glumes with a shorter mucro and more slender bases (which give the plants a very different appearance).

Selected SPECIMENS (103 examined): QueENSLAND: Burke: Micky Spring, White Mtns area N of Hughenden, Godwin C2687, Aug 1984 (NSW). North Kennedy: W of Pentland between Warrigal and Burra, Blake 9947, Oct 1935 (BRI, K, MEL). Mitchell: Alice R., just E of Alice railway siding, Wilson et al. 3575-3577, May 1981 (NSW). Maranoa: Bollon, Swarbrick 5149, Sep 1970 (BRI). Warrego: 1 mile [1.5 km] W of Eulo on Thargomindah road, Phillips NSW 65101, Sep 1963 (NSW). NeW South Wales: North Western Plains: Moonie R., 'Goondabluie', McGillivray 2814, Nov 1967 (NSW, BRI, K). South Western Plains: Warranary Hills, c. $5 \mathrm{~km}$ direct WNW of Roto, Wilson $\mathcal{E}$ Murray 5892, Mar 1984 (NSW). North Far Western Plains: 1 mile [1.5 km] W of Mootwingie Historic Site HQ., De Nardi 875, Sep 1971 (NSW, BRI, K); Paroo R. billabong, Wanaaring, Milthorpe $\mathcal{E}$ Cunningham 5175, 5176, May 1977 (NSW). SOUTH Australia: Lake Eyre: Todmorden Station, $42 \mathrm{~km} \mathrm{~W}$ of Oodnadatta, Henshall 3486, May 1980 (NSW). Gairdner-Torrens: $2.9 \mathrm{~km} \mathrm{SW}$ of Millars Creek HS., Chinnock 2589, Sep 1975 (AD). Flinders Ranges: Gammon Ranges, Arcoona Creek, Eichler 12682, Sep 1956 (AD); lower slopes Mt John, Wilpena, Symon 618, Sep 1960 (AD, K). 
Eastern: Panaramitee, c. 10 km SE of Yunta, Gardiner 6, Aug 1962 (AD). Eyre Peninsula: Hiltaba Station, c. 2 km NW of HS., Blaylock 1982, Sep 1972 (AD). WESTERN AustraLIA: Carnarvon: flats of Gascoyne R., Carnarvon, Aplin 1559, May 1962 (PERTH). Austin: $70 \mathrm{~km} \mathrm{~W}$ of Mt Magnet on Yalgoo road, Wilson 2623, Sep 1979 (NSW, CHR, K, P, PERTH). Helms: 3 miles [5 km] E of Laverton, George 4465, June 1963 (PERTH, BRI). Irwin: $30 \mathrm{~km}$ SE of Mingenew on Three Springs road, Wilson 2675, Oct 1979 (NSW, K). Avon: near Mt Caroline, Sewell, 1889 (MEL, BRI).

Plants found along the stream lines from Oodnadatta north to Charlotte Waters and New Crown Station just over the S.A.-N.T. border appear morphologically intermediate between $C$. alterniflorus and $C$. centralis (q.v.) and require further study. The plants are generally stout and deep-rooted as in $C$. alterniflorus but have bases of a rather papery texture as found in $C$. centralis. The leaf marginal prickles are more or less densely antrorsely aculeate and irregularly spaced. The inflorescences generally have the look of $C$. centralis and the nut is nearly as long and narrow as in $C$. centralis. Glumes are yellow to dark golden-brown (never red-brown). Specimens of this taxon were listed by Eardley (1946: 157) as $C$. alterniflorus and ' $C$. dactylotes forma vel sp. aff.', based on Blake's determinations. The specimen 'Staer, Oodnadatta' was referred (with some doubt) to C. clarus by Blake (1943: 53) and Black (1943). Bentham (1878) and Ewart \& Davies (1917) cited under C. fulvus a specimen (Giles, Charlotte Waters, n.v.) that may belong to this taxon.

SPECIMENS OF OODNADATTA FORM: NORTHERN TeRRITORY: Central South: Charlotte Waters, Crocker, May 1939 (AD 97447289, BRI), Giles, 1875 (MEL); New Crown Station, Latz 6861, Apr 1977 (NT, NSW). South Australia: Lake Eyre: Oodnadatta, Andrew, May 1936 (AD 97519318), Cleland, Oct 1945 (AD 96226084), Staer (herb. Black), Jan 1913 (AD 97519089); Woorong Creek, Mt Clarence area, WNW Coober Pedy, Beauglehole 20148, Oct 1966 (NT); Abminga Creek, Crocker, June 1939 (AD 97545504); Abminga [c. $10 \mathrm{~km}$ S of border], Ising, July 1976 (AD 966021513); Oodnadatta, beside Neales, Knight 183, Dec 1977 (AD); Mt Dare HS., Abminga Creek, Latz 4810, Apr 1974 (NT); near Horn Expedition Camp 2, S of Macumba Hill, Tate, May 1894 (AD 96014160); The Neales, $7 \mathrm{~km}$ SW of Oodnadatta, Wilson 4612, Apr 1983 (NSW, AD); The Neales (S Branch) c. $70 \mathrm{~km} \mathrm{~W}$ of Oodnadatta, Wilson 4613, Apr 1983 (NSW, AD).

23. Cyperus lhotskyanus Boeck.

Boeckeler (1884: 498); Wilson (1980: 664); Cunningham et al. (1981: 162); Beadle et al. (1982: 606); Wilson (1987: 1129).

TYPE: Nova Hollandia, Lhotsky; holo KIEL.

Mariscus rutilans C.B. Clarke (1908: 18); Domin (1915: 443). Cyperus rutilans (C.B. Clarke) Maiden \& Betche (1916: 28); Blake (1943: 53), p.p.; Black (1943: 145), p.p., (1978: 267), p.p.; Kükenthal (1935-36: 455, Figure 50G-H), p.p. max.; Willis (1962: 222), (1970: 222); Burbidge \& Gray (1970: 79). TyPe: New South Wales: Armidale, Perrott, as 'Parrott'; lecto K (Wilson 1980: 664).

[Cyperus gunnii auct. non Hook. f.: Bentham (1878: 283), p.p. min. (Parrott, Armidale; Moore, Liverpool Plains)]

Slender perennial, shortly rhizomatous with solitary culms or tufted, $20-65 \mathrm{~cm}$ high, not viscid; bases sometimes slightly subbulbous, dark red-brown; rhizomes short, black, fibrous. Culms trigonous to subterete below, smooth, 1.2-3 mm diam. Leaves flat to carinate, occasionally septate-nodulose, shorter than to longer than culms, to 4 mm wide, bluish green; midrib usually obvious abaxially, smooth or scabrous towards apex; marginal prickles dense to sparse, irregularly spaced (0.1-1.4 $\mathrm{mm}$ apart), short, $0.05-0.10 \mathrm{~mm}$ long, antrorse to erect or flabellate, aculeate; leaf sheaths not or occasionally septate-nodulose, dull, whitish or stramineous above, purplish red-brown below with hyaline margins red-brown near apex. Inflorescence simple to compound, $3-7(-12)$ primary branches to $11 \mathrm{~cm}$ long; bracts erect to spreading, (1-)2(-3) about 
twice as long as the inflorescence. Spikelets numerous in subdigitate, dense, hemispherical to globose clusters of 1-2.5(-4) cm diam.; spikelets compressed, oblong, 6$12(-25) \mathrm{mm}$ long, $2.5-4 \mathrm{~mm}$ wide in side view, 6-10(-30)-flowered; rachilla not thickened, not to broadly winged, wings to $0.15 \mathrm{~mm}$ wide; glume spacing $1.2-1.6(-2.0)$ $\mathrm{mm}$; spikelet falling as a unit, or rachilla persistent and glumes falling individually. Glumes narrow-ovate to elliptic, retuse to acute with straight or excurved mucro $0.1-0.5 \mathrm{~mm}$ long, red-brown with green midrib, $2.6-4.0 \mathrm{~mm}$ long, $0.8-1.0 \mathrm{~mm}$ wide, sides 2-4-nerved, margins loosely inrolled and narrow-membranous. Anthers 1.3-1.7 $(-2.0) \mathrm{mm}$ long excluding appendage $\leq 0.1 \mathrm{~mm}$ long. Nut trigonous, narrow-obovate to narrow-elliptic with acute apex, faces flat, yellow-brown, colliculate to smooth and reticulate-areolate, shining, $1.8-2.1(-2.5) \mathrm{mm}$ long, c. $3 / 4$ as long as glume, $0.6-0.8 \mathrm{~mm}$ diam., falling with glume mostly. Figure $25 j-1$.

Distribution: Extending from the Tablelands and Western Slopes of New South Wales to south-eastern South Australia. Figure 26b. Probst (1949) lists this species as a woolalien at Derendingen, Switzerland, in 1926 and 1927 (as C. rutilans). Ryves (1976) similarly lists this species for Blackmoor Fruit Farm, $\mathrm{N}$ Hants., England.

HABITAT: Sandy to clay soils; in seasonally wet sites (creek banks, floodways).

This species is related to C. alterniflorus (q.v.), C. gunnii (q.v.) and C. secubans (q.v.). It is readily distinguished in the field from all these species by its shortly rhizomatous habit.

Kükenthal (1935-36) cited Koch 391 under this species. However, Koch used species numbers rather than collection numbers and he obviously had a confused idea of the taxon he was collecting. Most sheets under that number belong to $C$. alterniflorus but one sheet is C. victoriensis C.B. Clarke; none is C. Ihotskyanus. Kükenthal also cited Dietrich 615, from Port Mackay, under this species. I have not seen the specimen but it is likely to be C. subulatus R. Br. or some other species from another Section.

Selected specimens (96 examined): New South Wales: Central Coast: Wolgan R., Newnes, c. 1600 ft [485 m] alt., Johnson, Nov 1959 (NSW 65140). South Coast: Eden to Pambula, Maiden, Nov 1901 (NSW 22683, K). Northern Tablelands: Ollera Creek, $4.5 \mathrm{~km} \mathrm{~S}$ of Wandsworth on Guyra road, Wilson 4330, Jan 1982 (NSW, H, K, P). Central Tablelands: Orange, Boorman, Jan 1908 (NSW 122306, BRI, K, P). Southern Tablelands: near Tharwa, A.C.T., Blake 7540, Feb 1935 (BRI, K, NSW, NT, PERTH). North Western Slopes: Tower Hill Creek, $3.5 \mathrm{~km}$ W of Nullamanna turnoff on Strathbogie-Bukkulla road, Wilson 6226, May 1985 (NSW, NE). Central Western Slopes: Denman, Earp NSW 30931, Feb 1955 (NSW, BRI, K); 5 km along Tullamore road from CondobolinParkes road, Wilson 5956, Nov 1984 (NSW, H, K, P, UB). South Western Slopes: Ardlethan, Boorman, Nov 1917 (NSW 15644, K). South Western Plains: Humbug (Euglo) Creek c. $5.5 \mathrm{~km}$ direct SW of Winnunga, Wilson 5625, Nov 1983 (NSW, H, K, P); Sandy [Crowl] Creek, $10 \mathrm{~km}$ NW of Lachlan Downs HS., Wilson \& Murray 5891, Mar 1984 (NSW). VICTORIA: C: Wonwondah East, Wilson \& Johnson 1077, Feb 1975 (NSW, MEL). J: Narrampumelap, $11 \mathrm{~km}$ SSW of Willowra P.O., Beauglehole 61630, Nov 1978 (MEL, NSW). R: Winton Swamp, 9 miles [15 km] ENE of Benalla, Aston WS 35, Feb 1959 (MEL). U: Walwa, McBarron 1303, Dec 1947 (BRI). W: Orbost, on the Snowy R. flats, Hunter, Dec 1943 (MEL). South Australia: South-eastern: c. $1.5 \mathrm{~km} \mathrm{~S}$ of Naracoorte Caves, Hunt 2261, Nov 1964 (AD, BRI, CANB, K); Wrattonbully, c. $30 \mathrm{~km}$ SSE of Naracoorte, Gurrs Swamp, Hunt 2338, Jan 1965 (AD).

\section{Cyperus centralis K.L. Wilson, sp. nov.}

C. alternifloro et C. lhotskyano affinis; sed a C. alternifloro habitu graciliore, basibus subbulbosis, aculeis marginum foliorum sparsioribus brevioribusque, mucrone glumae recto, differt; a C. lhotskyano defectu rhizomatis, aculeis marginum foliorum plusminusve regulariter antrorsis, saepe longioribus, differt.

TYPE: NoRTHERn TERrITORY: Central South: Hull River, P.K. Latz 4173, 26 Aug 1973; holo NSW; iso $\mathrm{K}, \mathrm{NT}$, PERTH. Figure 27a. 

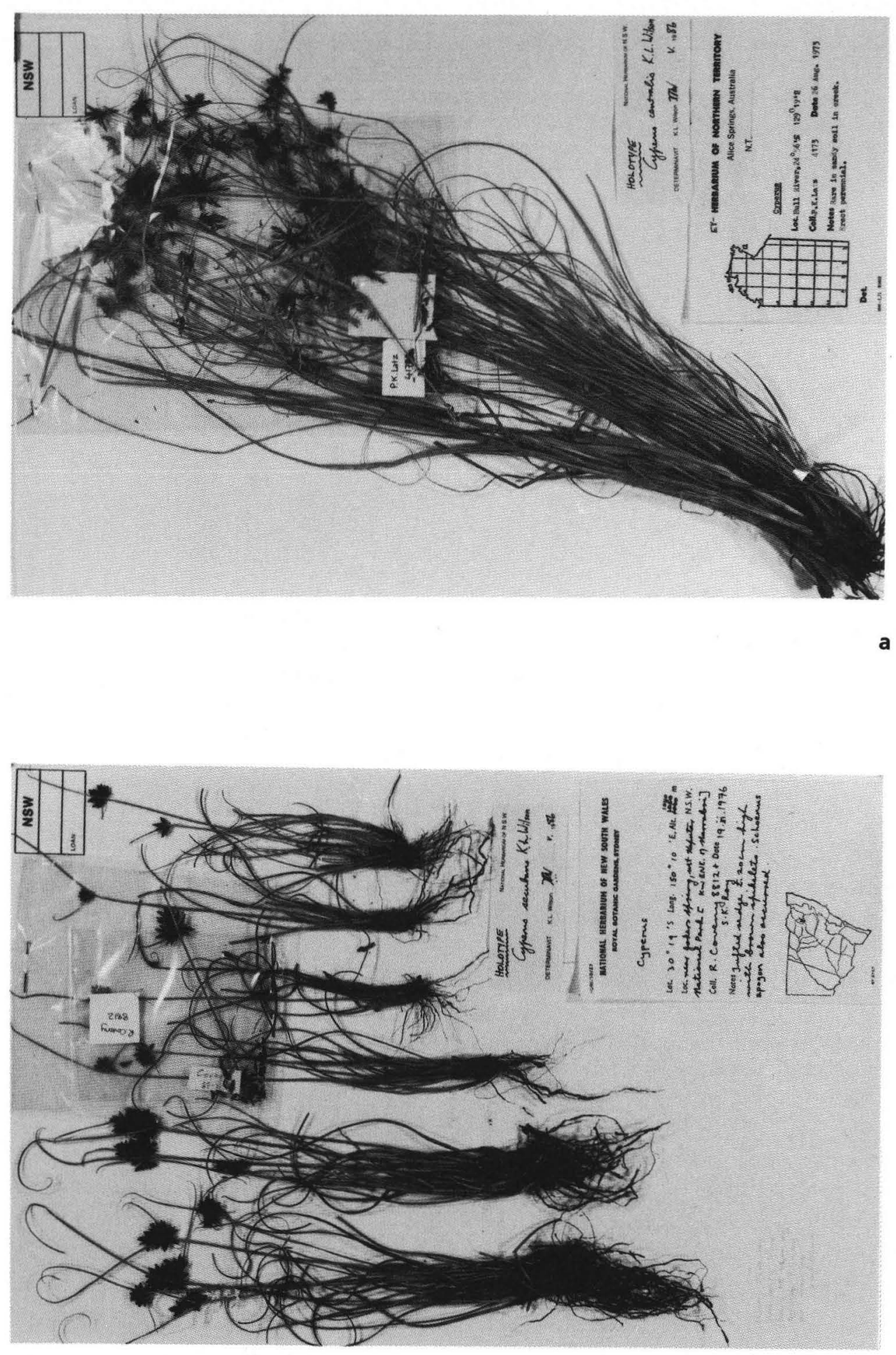

Figure 27. Holotype of a, C. centralis; b, C. secubans. 


\section{[C. sp. aff. cunninghamii Wilson (1981a: 508, Figure 638G)]}

Tall but slender perennial, tufted, often with rather long surculi and a thickened somewhat bulbous base, $40-110 \mathrm{~cm}$ high, not viscid. Culms trigonous to triquetrous, often slightly scabrous, $1-2.5 \mathrm{~mm}$ diam. Leaves flat to carinate or canaliculate, usually not septate-nodulose, < culms, to $3.5 \mathrm{~mm}$ wide; midrib \pm obvious abaxially, usually smooth; marginal prickles dense to sparse, mostly regularly spaced $(0.1-0.6(-1.1) \mathrm{mm}$ apart), long to short, (0.05-)0.1-0.2 mm long, antrorse, aculeate; leaf sheaths usually not septate-nodulose, finely striate, not shining, stramineous above, purple-red below. Inflorescence simple or small-compound, 4-12 primary branches to $10 \mathrm{~cm}$ long; bracts suberect to spreading, 2-3 much exceeding the inflorescence. Spikelets c. 12 in loose, spicate to subdigitate, hemispherical clusters of $0.7-2.5 \mathrm{~cm}$ diam.; spikelets compressed, oblong to narrow-ovate, 5-13(-18) $\mathrm{mm}$ long, $1.5-3 \mathrm{~mm}$ wide in side view, 4-14(-18)-flowered; rachilla not thickened, not or narrowly winged, wings to 0.05 mm wide; glume spacing 1.1-2.3 mm; spikelet falling as a unit, or rachilla persistent and glumes falling individually. Glumes narrow-elliptic to narrow-ovate, acute with straight mucro $<0.1-0.3 \mathrm{~mm}$ long, stramineous to golden to red-brown with green midrib, 2.5-3.8 mm long, 0.5-1.0 mm wide, sides (1-)2-4-nerved, margins inrolled and narrow-membranous. Anthers $1.3-2.3 \mathrm{~mm}$ long excluding appendage $\leq 0.1(-0.2) \mathrm{mm}$ long. Nut trigonous, very narrow-elliptic with acute apex, faces flat to convex, pale brown, shortly elongate-colliculate to foveate, glistening or shining, $1.7-2.2 \mathrm{~mm}$ long, $1 / 2-3 / 4$ length of glume, $0.3-0.7 \mathrm{~mm}$ diam., falling with glume. Figure $28 \mathrm{a}-\mathrm{c}$.

Distribution: Central Australia (Central North and South), and adjoining areas of Western Australia and South Australia. Figure 26b.

HABITAT: Sandy soils; in the ranges, in seasonally wet situations (rockholes, gullies, stream banks and beds).

The epithet refers to the species' occurrence in the geographical centre of Australia; from the Latin centralis, in the middle or central.

C. centralis shows similarities to $C$. alterniflorus and the more mesic species C. lhotskyanus, but differs from both in the form of the marginal prickles on the leaves. $\mathcal{C}$. centralis differs from $C$. alterniflorus in being more slender, with the prickles on the leaf margins sparser, less regular, shorter and more slender, and the leaf midrib not strongly scabrous on the lower surface. $C$. alterniflorus has glumes with a more obtuse apex and a more excurved mucro. C. lhotskyanus differs from $C$. centralis in being mostly shortly but distinctly rhizomatous, with bases that are distinctively coloured (dull purple-red below, whitish or stramineous above), and in having irregularly spaced mixed-type prickles on the leaf margins.

Specimens seen in various herbaria in the early stages of this study were labelled as C. sp. aff. cunninghamii. C. centralis can be distinguished from C. cunninghamii by the latter's viscidity, tufted habit, generally more slender and canaliculate leaves with longer marginal prickles, often terete spikelets, glume colour, and broadly winged rachilla.

C. centralis differs from $C$. betchei subsp. commiscens in its red-brown glumes (occasionally stramineous or golden with red-brown blotches), the often fewer-flowered spikelets, and the generally shorter spikelets and longer anthers. It also differs from C. dactylotes in glume colour, as well as in anther length, in its often relatively long surculi, its usually broader spikelets, and its greater glume spacing, glume length and nut length.

The relatively few specimens I have seen from Western Australia are generally more robust (e.g. Carolin 5796, George 4581). Plants found along streamlines from Oodnadatta to Charlotte Waters seem intermediate between this species and C. alterniflorus 
(q.v.). Similarly, specimens from the northern part of the arid zone appear intermediate between this species and C. carinatus (q.v.).

Selected SPECIMENS (120 examined): NorTherN TerRrTory: Central North: Mt Doreen Station, Latz 2012, Jan 1972 (NT, NSW); Wartupunya Rockhole, Latz 2134, Jan 1972 (NT, NSW); Central Mount Stuart, Latz 5579, July 1974 (NT, BRI, NSW). Central South: Valley of the Eagles, Beauglehole 24364, July 1967 (NSW, NT); George Gill Range, Carmichaels Crag, Beauglehole 26245, July 1968 (NT);
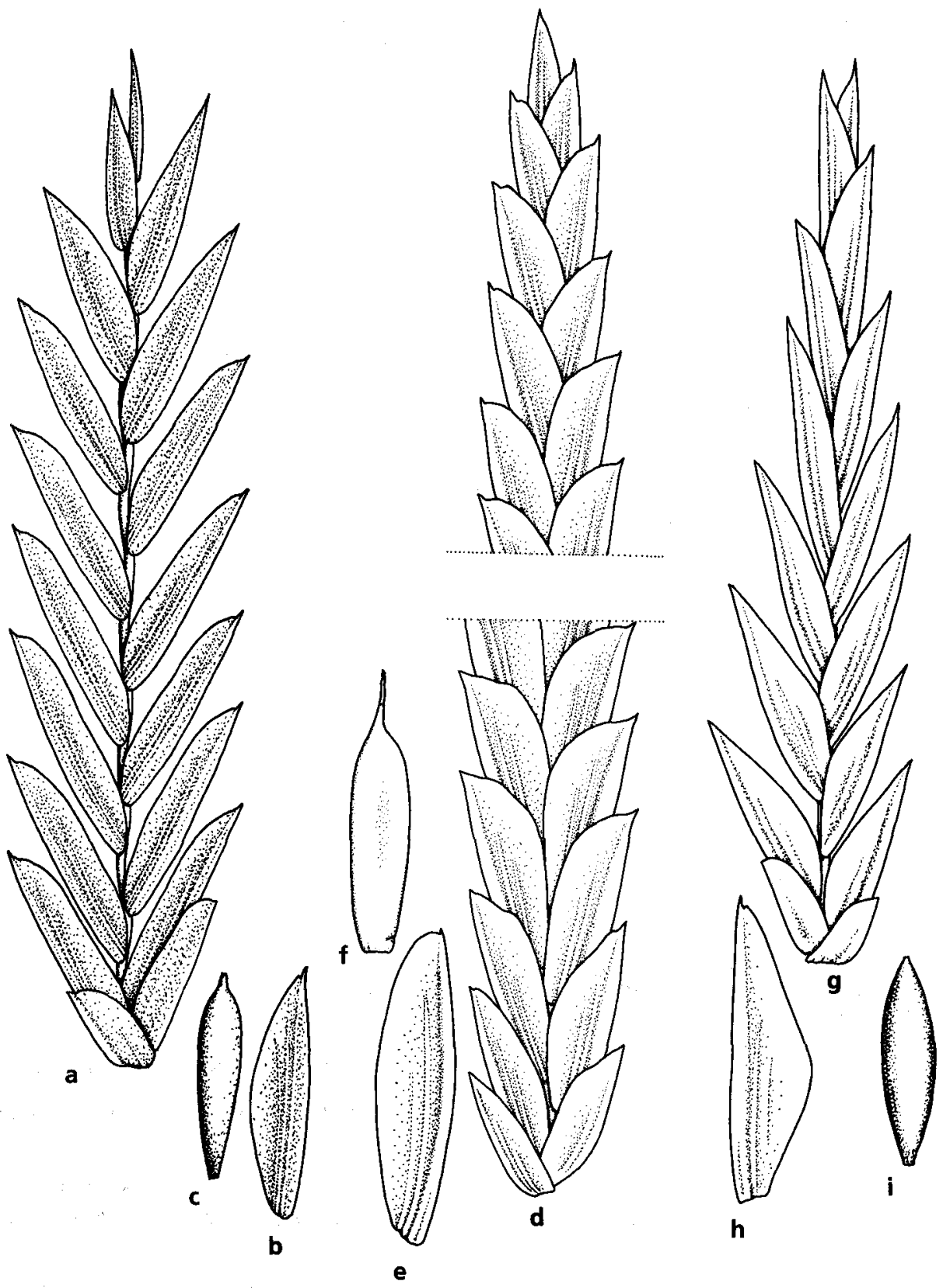

Figure 28. Spikelet details. C. centralis: a, spikelet; b, glume; c, nut. C. secubans: $\mathbf{d}$, spikelet; $\mathbf{e}$, glume; $\mathbf{f}$, nut. $C$. isabellinus: $\mathbf{g}$, spikelet; $\mathbf{h}$, glume; $\mathbf{i}$, nut. a-c from Latz 2134; $\mathbf{d}-\mathbf{f}$ Coveny 8879; $\mathbf{g}-$ i Wilson 4199. a, d, g X 11; b, c, e, f, h, i X 14. 
Standley Chasm, Heavitree Range, Chippendale 522, Nov 1954 (NT, BRI, CANB, MEL, NSW, PERTH), McKee 8657, Feb 1961 (BRI, CANB, K); Palm Valley, Latz 1872, Dec 1971 (NT), Wilson 3883, May 1981 (NSW); Kulgera, Chippendale \& Johnson, Oct 1957 (NT 3977, AD, BRI, MEL, NSW, PERTH); Docker R, Petermann Ranges, Chippendale, June 1958 (NT 4562, AD, BRI, MEL, NSW, PERTH); summit of Ayers Rock, Jackson 115, Aug 1959 (AD), Schodde 410, Aug 1957 (AD, CANB, K); 26 miles [42 km] NE of Docker R. Settlement, Latz 871, Oct 1970 (NT, BRI, L); Fringe Lily Gorge, east Chewing Range, Latz 9970, Oct 1984 (NSW ex NT). SoutH Australia: North-western: near Watarunya Rockhole, Barker 3069, Aug 1978 (AD); Everard Ranges, Everard Park, Forde 911, Sep 1957 (AD, BRI, NT); Everard Range, gorge N of Victory Well, Eichler 17443, Sep 1963 (AD, K); Cave Hill, N of Musgrave Range, George 5176, July 1963 (PERTH, BRI); Mt Lindsay, Symon 2567, Aug 1962 (AD, K, PERTH); Everard Range, Mt Carmeena, Whibley 1176, Sep 1963 (AD, NSW). WeSTERN AUSTRALIA: Ashburton: 72 miles [116 km] N of Meekatharra, George 3638, Mar 1962 (PERTH). Giles: Giles Creek, S of Dean Range, Carolin 6066, Aug 1967 (SYD); Walter James Range, Bungabiddy Waterhole, Carolin 6245, Aug 1967 (SYD), George 8312, Oct 1966 (PERTH); Rawlinson Range, c. 4 miles [6 km] N of Giles, Hill \& Lothian 826, July 1958 (AD, K).

\section{Cyperus secubans K.L. Wilson, sp. nov.}

C. rigidello affinis sed foliis crassioribus canaliculatisque, aculeis marginum foliorum, colore glumarum, antheris longioribus, differt.

TYPE: NeW SOUTH WALES: Northern Tablelands: near Jokers Spring, Mt Kaputar National Park, R. Coveny 8812 \& S. Roy, 19 Nov 1976; holo NSW; iso BRI. Figure 27b.

Slender perennial, tufted with slightly bulbous bases, $15-25 \mathrm{~cm}$ high, usually somewhat viscid. Culms terete or slightly flattened, smooth or scabrous, $0.8-1.2 \mathrm{~mm}$ diam. Leaves canaliculate, thickened, usually curly, not septate-nodulose, $3 / 4$ as long as to equalling the culms, to $1.4 \mathrm{~mm}$ wide; midrib not obvious abaxially; marginal prickles sparse, regularly spaced (0.1-1.3 mm apart), short, $0.05-0.10 \mathrm{~mm}$ long, erect or flabellate, papillate, occasionally mixed with rather blunt antrorsely aculeate prickles; leaf sheaths not septate-nodulose, not smooth or shining, striate, pale brown with red-brown blotches. Inflorescence simple, densely clustered or with 1-3 primary branches to $4 \mathrm{~cm}$ long; bracts erect, usually curly, 1-2 exceeding the inflorescence. Spikelets 10-15 in small, dense to loose, subdigitate, globose clusters of $1.0-1.5 \mathrm{~cm}$ diam.; spikelets compressed, oblong, 7-9 mm long, 2.5-3.5 mm wide in side view, 4-8flowered; rachilla not thickened, narrowly winged, wings to $0.05 \mathrm{~mm}$ wide; glume spacing 1.0-1.7 mm; spikelet falling as a unit or rachilla persistent and glumes falling individually. Glumes ovate to elliptic, retuse to broad-acute with straight mucro $\leq 0.1$ $\mathrm{mm}$ long, red-brown to dark red-brown with a green midrib, 2.5-3.0 mm long, 0.8$1.2 \mathrm{~mm}$ wide, sides 3-4-nerved, margins narrow-hyaline and only slightly inrolled. Anthers $1.3-1.6 \mathrm{~mm}$ long excluding appendage $0.1 \mathrm{~mm}$ long. Nut trigonous, narrowobovate to narrow-elliptic with acute apex, faces flat, pale to dark brown, colliculate to smooth and reticulate-areolate, shining, 1.6-2.1 $\mathrm{mm}$ long, $3 / 4-7 / 8$ as long as the glume, $0.6-0.8 \mathrm{~mm}$ diam., falling with glume. Figure $28 \mathrm{~d}-\mathrm{f}$.

Distribution: Restricted to the Nandewar Range of New South Wales. Figure 26c.

HABITAT: In rock crevices on rock shelves; often slightly swampy open sites at higher altitude, apparently associated with outcrops of volcanic origin.

The epithet is derived from the Latin secubare, to lie or sleep by oneself, hence by transference to live alone; in reference to the species' physical isolation from others of section Pinnati.

C. secubans shows morphological similarities to both C. rigidellus and C. lhotskyanus. It differs from $C$. rigidellus in having mixed-type prickles on the leaf margins, longer anthers, glumes more or less evenly dark red-brown, and with a straight mucro $\leq 0.1$ 
$\mathrm{mm}$ long. It differs from $C$. lhotskyanus in the shorter, mixed prickles on its leaf margins, in its thickened, curly and canaliculate leaves and bracts without midrib, its shorter glume mucro, and its tufted habit.

C. fulvus also grows in the Nandewar Range but in drier habitats. It differs from C. secubans in its thinner-textured leaves with longer marginal prickles, its stramineous to golden-brown glumes with red-brown blotches and its shorter anthers.

SpeCIMENS EXAMINED: New South Wales: Northern Tablelands: Coveny \& Roy 8812 (NSW, BRI); 26 km ENE of Narrabri towards Dawsons Spring, Coveny \& Roy 8879, Nov 1976 (NSW, BRI, K, P), Coveny \& Roy 8881, Nov 1976 (NSW); Waa Gorge, Mt Kaputar National Park, Coveny \& Roy 9006, Nov 1976 (NSW); 1-2 miles [3-5 km] W of Mt Kaputar, Johnson \& Constable, Nov 1954 (NSW 30757); Mt Coryah, Mt Kaputar National Park, Wilson 1334, Oct 1975 (NSW), Wilson 6995, Nov 1986 (NSW, BRI, K); Mt Yulludunida, Mt Kaputar National Park, Wilson 1348, Oct 1975 (NSW).

\section{Cyperus isabellinus K.L. Wilson, sp. nov.}

C. rigidello affinis sed aculeis marginum foliorum, colore formaque glumarum, rhachilla alata, superficie nucis, differt.

TYPE: QueENSLAND: Darling Downs: $6 \mathrm{~km} \mathrm{~S}$ of Yandilla-Tummaville road on Owens Scrub Road to Leyburn, K.L. Wilson 4199, 30 Dec 1981; holo NSW; iso BRI, CANB, K, L, NT, NY. Figure 29a.

Slender annual or short-lived perennial, tufted, shallow-rooted, 30-55 cm high, not viscid. Culins obscurely trigonous to subterete, rather soft (therefore compressed when pressed and dried), smooth, 1-2.5 mm diam. Leaves flat but keeled, usually septatenodulose, $2 / 3$ as long as to equalling culms, to $3.8 \mathrm{~mm}$ wide; midrib obvious abaxially, smooth or scabrous; marginal prickles dense to sparse, mostly regularly spaced (0.2$1.3 \mathrm{~mm}$ apart), short to long, $0.05-0.15 \mathrm{~mm}$ long, antrorse, aculeate; leaf sheaths septate-nodulose, not shining, stramineous with occasional dark red-purple blotches. Inflorescence simple or small-compound, 6-12 primary branches to $11.5 \mathrm{~cm}$ long; bracts erect to spreading, (2-)3-4 exceeding the inflorescence. Spikelets 6-15 in subdigitate, loose, hemispherical to globose clusters of $1-5 \mathrm{~cm}$ diam.; spikelets compressed, oblong, 6-22(-38) $\mathrm{mm}$ long, 2.0-2.5 $\mathrm{mm}$ wide in side view, 8-18(-38)-flowered; rachilla not thickened, narrowly to broadly winged, wings $0.05-0.2 \mathrm{~mm}$ wide; glume spacing 1.5-1.8 mm; spikelet falling as a unit, or rachilla persistent and glumes falling individually. Glumes narrow-ovate to elliptic, acute with straight mucro $0.2-0.5 \mathrm{~mm}$ long, stramineous to golden-brown with very occasional red-brown blotches and green midrib, 2.7-3.4 mm long, 0.7-0.9 mm wide, sides 2-3-nerved, margins inrolled and narrow-membranous. Anthers $0.8-1.3 \mathrm{~mm}$ long excluding appendage $<0.1 \mathrm{~mm}$ long. Nut trigonous, narrow-elliptic to narrow-obovate with acute apex, faces flat to convex, pale yellow-brown, colliculate to foveate, shining to glistening, $1.8-2.5 \mathrm{~mm}$ long, $7 / 8$ as long as to equalling glume, $0.6-0.8 \mathrm{~mm}$ diam., falling with glume. Figure $28 \mathrm{~g}-\mathrm{i}$.

Distribution: Only known from the North Kennedy, Leichhardt and Darling Downs regions of eastern Queensland. Figure 26c.

HABITAT: Clayey soils; apparently restricted to gilgais ('melon-holes') in brigalow forest or around depressions or along drains in belah (Casuarina cristata) woodland.

The epithet refers to the yellowish glumes and is from the neo-Latin isabellinus, meaning tawny yellow (see Stearn (1973) and the Sociéte française des Chrysanthémistes (1905) for the tale behind the meaning).

One specimen, White 8887, from near Townsville, differs from others in its nut surface, which resembles that of $C$. fulvus in being olive-brown rather than yellowish, 

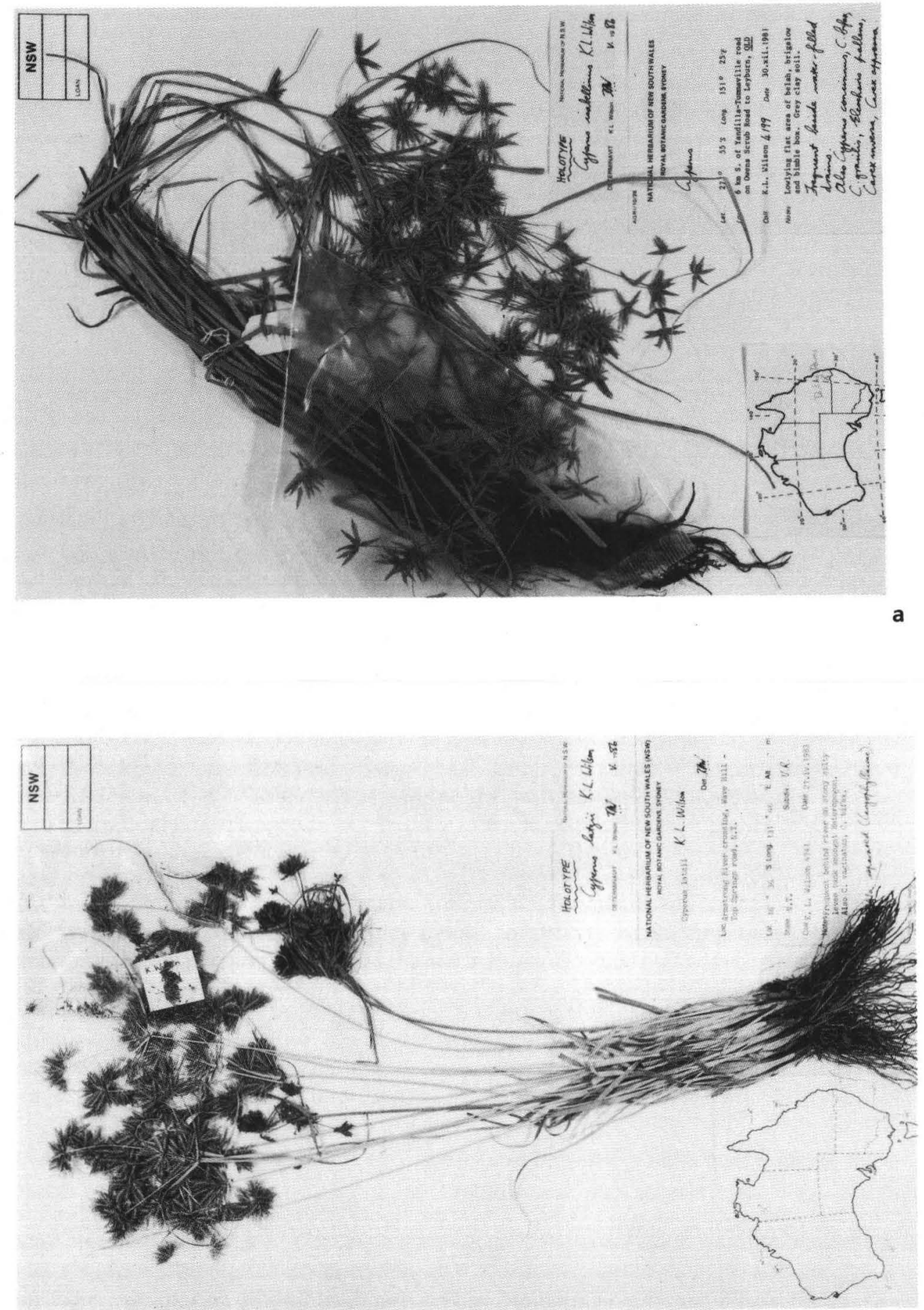

Figure 29. Holotype of a, C. isabellinus; b, C. latzii. 
with smaller surface reticulations. Similarly, a specimen from Palardo (Blake 5837) exhibits a mixture of features that suggests it is a hybrid between these two species.

C. isabellinus is related to $C$. rigidellus but differs in the prickles on its leaf margins, in glume colour and shape, in the winged rachilla (also winged in one form of C. rigidellus) and in the nut surface, which has larger reticulations. Another related species is $C$. clarus, from which it differs in its marginal prickles, its narrower spikelets with winged rachilla and greater glume spacing, its straight glume mucro, and its nut shape, colour and surface reticulation. It differs from $C$. betchei in its much smaller, tufted habit, its broader spikelets, straight glume mucro, and broader nut with larger surface reticulations.

Specimens eXamined: QueEnSLAND: North Kennedy: between Campaspe R. and Victoria Creek, Blake and Webb 1574B, Apr 1945 (BRI, K, L); 26 miles [42 km] S of Charters Towers on Clermont road, R.W. Johnson 1835, May 1960 (BRI). Leichhardt: 8 km SE of Emerald, Godwin, May 1976 (BRI 216727); $15 \mathrm{~km} \mathrm{~S}$ of Emerald, R.W. Johnson 1356, Feb 1960 (BRI); Roundstone, R.W. Johnson 1689, May 1960 (BRI); Cottenham, c. $20 \mathrm{~km}$ NW of Banana, R.W. Johnson 1715, May 1960 (BRI). Port Curtis: Callide Valley, White 10874, Apr 1937 (BRI). Darling Downs: near Brigalow, Blake 13308, Feb 1938 (BRI); N of Jackson, 'Cypress Downs', Blake 19155, Mar 1953 (BRI, K, MEL, NSW); c. 10 miles [16 km] W of Meandarra, R.W. Johnson 743, Mar 1959 (BRI, CANB, K); Calala c. 10 miles [16 km] E of Meandarra, R.W. Johnson 1611, Apr 1960 (BRI); Chinchilla, Lithgow 46, Feb 1978 (BRI); The Deep, 16 miles [26 km] SSW of Tara, McDonald 130, Apr 1964 (BRI, CANB, K); 18 miles [29 km] N of Jackson, Melville et al. 3444, Mar 1953 (K, MEL, NSW, PERTH); c. $0.5 \mathrm{~km}$ S of Mulga Ridge, NW of Talwood, Wilson 1862, Mar 1978 (NSW); c. $2.5 \mathrm{~km}$ SE of Brigalow on Dalby road, Wilson et al. 3348, Apr 1981 (BRI, NSW, P); between Inglewood and Milmerran, White 9680, Jan 1934 (BRI, K).

27. Cyperus rigidellus (Benth.) J. Black

Black (1929: 676), (1943: 145), (1978: 261, Figure 233); Kükenthal (1935-36: 457); Blake (1940: 43); Blake (1943: 53); Blake in Eardley (1946: 157); Willis (1962: 218), (1970: 218); Wilson (1981a: 508); Cunningham et al. (1981: 162); Sharpe (1989: 324, Figure 47F). C. gracilis var. rigidellus Bentham (1878: 266), as 'var. ?rigidella', p.p. Mariscus rigidellus (Benth.) C.B. Clarke (1908: 18); Domin (1915: 445).

TYPE: SOUTH Australia: Lake Eyre, Andrews 122; lecto K (here designated).

Cyperus subpinnatus Kükenthal (1931: 199); Kükenthal (1935-36: 453, Figure 50A-F); Cunningham et al. (1981: 163). TYPE: New South Wales: Nyngan, Baeuerlen 20; lecto B (here designated); isolecto NSW, as 'Baeuerlen 2521, xii.1899'.

Cyperus subpinnatus var. subrigidellus Kükenthal (1931: 200); Kükenthal (1935-36: 453). TYPE: SOUTH Australia: Tinga-tingana ('Lake Torrens Gebiet'), Basedow; lecto B (here designated), locality cited as 'Lake Torrens'.

[C. enervis auct. non R. Br.: Black (1922: 89)]

[C. gracilis auct. non R. Br.: Black (1922: 89); Ewart (1931:215), p.p]

[C. gilesii auct. non Benth.: Moore \& Betche (1893: 448)]

Slender annual or short-lived perennial, tufted, shallow-rooted, 6-30 cm high, occasionally viscid especially about the inflorescence. Culms triquetrous to terete, often scabrous at least near the apex, $0.6-1.3 \mathrm{~mm}$ diam. Leaves carinate to canaliculate, somewhat thickened, not septate-nodulose, shorter than to exceeding the culms, to 3 mm wide, usually curly at the apex; midrib occasionally obvious abaxially, smooth or scabrous; marginal prickles sparse to very sparse, irregularly spaced (0.3-2.6 mm apart), long to short, (0.05-)0.10-0.2 mm long, erect, papillate; leaf sheaths not septate-nodulose, smooth, not shining, pinkish to purple-red (stramineous near top). Inflorescence 
simple, 1-4 primary branches $1-6 \mathrm{~cm}$ long; bracts mostly spreading but with at least one erect, tending to curl at the apex, 1-3 exceeding the inflorescence. Spikelets 5-15 in dense to loose, subdigitate, hemispherical to globose clusters of $1-3.0(-3.5) \mathrm{cm}$ diam.; spikelets compressed, oblong, 4-20(-27) $\mathrm{mm}$ long, 2.5-4.0 mm wide in side view, 620(-36)-flowered, occasionally viscid; rachilla not thickened, narrowly or broadly winged, wings $0.05-0.15 \mathrm{~mm}$ wide; glume spacing $1.3-2.3 \mathrm{~mm}$; spikelet falling as a

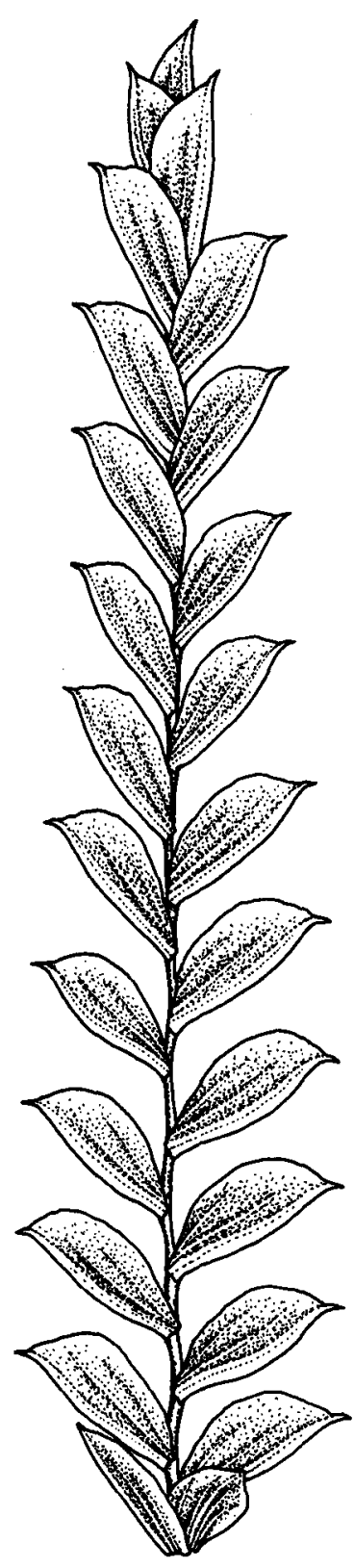

a

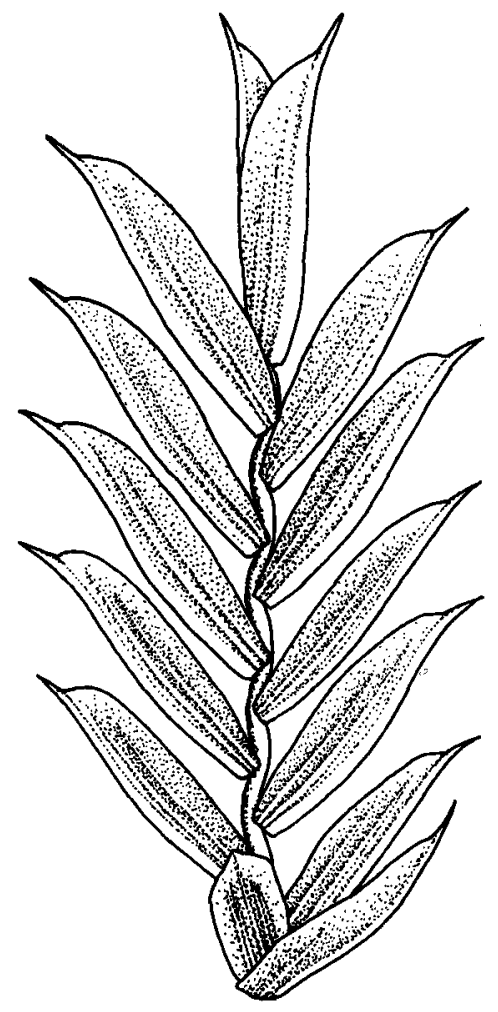

d

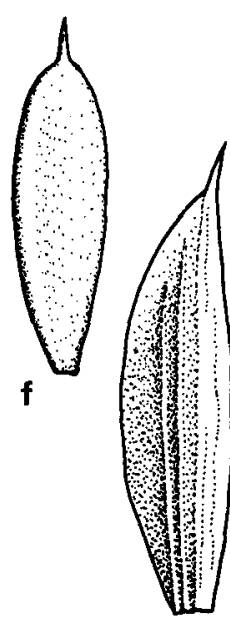

Figure 30. Spikelet details. Short- and long-glumed examples of $C$. rigidellus: $\mathbf{a}, \mathbf{d}$, spikelet; $\mathbf{b}, \mathbf{e}$, glume; c, f, nut. C. clarus: g, spikelet; h, glume; $\mathbf{i}$, nut. a-c from Latz 5016; d-f Briggs 4568; g-i Blake 5174. a, d, g X 11; b, c, e, f, h, i X 14 . 
unit, or rachilla persistent and glumes falling individually. Glumes elliptic to narrowovate to ovate, with the green midrib often distinctly curved in side view, acute to obtuse, with straight to excurved mucro $0.1-0.4 \mathrm{~mm}$ long, stramineous with red-brown blotches or evenly red-brown, 1.8-3.5(-4.7) $\mathrm{mm}$ long, $0.7-1.0 \mathrm{~mm}$ wide, sides (1-)23-nerved, margins somewhat inrolled and narrow-hyaline. Anthers 0.3-1.2 mm long excluding appendage $\leq 0.1 \mathrm{~mm}$. Nut trigonous, narrow-obovate to very narrow-elliptic with acute apex, faces concave to convex, pale brown, tuberculate or small-colliculate, glistening, $1.3-3.2 \mathrm{~mm}$ long, $3 / 4-7 / 8$ as long as the glume, $0.5-0.8 \mathrm{~mm}$ wide, falling with glume (only when spikelet is viscid). Figure $30 \mathrm{a}-\mathrm{f}$.

DisTRIBUTION: Widespread in southern inland Australia, extending only slightly north of the Tropic of Capricorn. Figure 26d. Ryves (1976) may be referring to this species, which is widespread in wool-producing areas, when he records the tropical species C. sporobolus as being a wool-alien at Blackmoor, England.

HABITAT: Sandy to clay-loam soils; in a wide range of ephemerally wet situations (creek or lake banks, floodways, waterholes, roadside drains, claypans, margins of saltpans).

C.B. Clarke effectively lectotypified Bentham's var. rigidellus as belonging to this species by citing Andrews 121, 122 (the two are mounted on the one sheet in K). The other specimen cited by Bentham belongs to $C$. fulvus. However, a type can only be one collection, so 122 is here designated as lectotype since it bears Clarke's diagnostic notes.

The lectotype chosen for $C$. subpinnatus (on the basis that it was the only potential lectotype that could be found in B) was cited by Kükenthal as 'Bäuerlen 20'. As with the many other specimens sent to him from NSW and the Technological Museum (now the Museum of Applied Arts and Sciences - its collections now in NSW), he cited only the number that was added to the duplicates and parent sheets when such duplicates were removed to be sent to him. The NSW duplicate of this type bears both Baeuerlen's number 2521 and the notation 'Sent to K. No. 20 '.

C. rigidellus is a variable species, especially in glume and mucro length, rachilla wing width and plant size. This variation may warrant taxonomic recognition, but further collection and preferably growing of plants under controlled conditions is needed to assess this. The species is related to $C$. gilesii (q.v.), C. clarus (q.v.) and C. secubans (q.v.).

SelECTED SPECIMENS (151 examined): QueENSLAND: Gregory North: Currawilla, c. 100 miles [160 $\mathrm{km}$ ] W of Windorah, Everist 3976, June 1949 (BRI, CANB, K). Mitchell: $2 \mathrm{~km}$ E of Reedy Creek on Bowen Downs-Lake Galilee road, Wilson et al. 3537, May 1981 (NSW, BRI, H, K, P, UB). Darling Downs: c. $3 \mathrm{~km}$ W of Yelarbon on Goondiwindi road, Wilson 1358, Oct 1975 (NSW, BRI). Maranoa: Boatman Station, Everist 2856, Mar 1947 (BRI, CANB, K). Warrego: Dynevor Lakes, 30 miles [48 km] E of Thargomindah, Blake 11762, June 1936 (BRI, K, MEL). Gregory South: 136.6 km NW of Nocundra, Boyland 3097, July 1971 (BRI). NeW SOUTH WALEs: North Western Plains: 'Iolanthe', c. 25 km SW of Garah, Wilson 1466, Apr 1976 (NSW, BRI, K, P, PH). South Western Plains: just W of Micabil Exclusion area, Wilson 5656, Nov 1983 (NSW, P). North Far Western Plains: $130 \mathrm{~km} \mathrm{~W}$ of Wanaaring on Milparinka road, Blaxell 621, Nov 1971 (NSW, AD, BRI, P). VICTORIA: A: Kings Billabong, southern end, Browne 77, Jan 1982 (NSW). C: Lake Hindmarsh, Reader, Apr 1895 (BRI, BM, EDIN). F: Lake Carpel, c. 19 km SE of Robinvale P.O., Beauglehole 56179, May 1977 (MEL, AD, NSW). NoRTHERN TeRritorY: Central North: Napperby Station, Latz 1962, Jan 1972 (NT, AD, CANB, NSW, PERTH). Central South: Mulga Park Station, Latz 5016, Apr 1974 (NT, AD, BRI, NSW). SOUTH AustraliA: North-western: c. $6 \mathrm{~km}$ WSW of Dingo Flat Gate, Lay 778, Apr 1973 (AD). Lake Eyre: Federal Swamp, Mount Dare Station, Latz 4805, Apr 1974 (NT, AD, NSW). Gairdner-Torrens: Oakden Hills, W of Lake Torrens, Murray 540, Apr 1930 (AD). Flinders Ranges: Mt Parry Gap, Murray, 1882 (AD 97609529). Eastern: c. $10 \mathrm{~km} \mathrm{~W}$ of Quinyambie HS., Whibley 3566, July 1971 (AD). Eyre Peninsula: head of Spence Gulf, N of Port 
Augusta, Adams in hb. Black, May 1921 (AD 97519321). Murray: Murray R. floodplain opposite Lyrup, Eichler 13763, Apr 1957 (AD). WESTERN AUSTRALIA: Mueller: just W of W.A.-N.T. border in $23^{\circ} 10^{\prime}$ S, George 8926, July 1967 (PERTH, CANB). Fortescue: 16 miles [26 km] from Onslow, Roebourne road, Carolin 7836, Aug 1970 (SYD, NSW). Carnarvon: $19 \mathrm{~km} \mathrm{~S}$ of Yannarie R., 170 km S of Onslow, Beauglehole 11645, Aug 1965 (NSW, NT, PERTH). Ashburton: $3 \mathrm{~km}$ E of Pell Creek, Cranfield 2020, Apr 1982 (PERTH). Austin: c. 22 miles [35 km] S of Mt Magnet, George 724, Apr 1960 (PERTH, BRI). Irwin: Geraldton, Gerstone 226, Nov 1963 (PERTH).

\section{Cyperus clarus S.T. Blake}

Blake (1940: 44), p.p. max.; Black (1943: 145), as to descr. only; Wilson 1987: 1136, Figure 484B; Sharpe (1989: 326, Figure 47K).

TYPE: QuEENSLAND: Darling Downs: Drayton, S.T. Blake 5174, 12 Feb 1934; holo BRI; iso K, MEL, NSW.

Slender annual or perennial, tufted, $20-90 \mathrm{~cm}$ high, not viscid. Culms triquetrous to trigonous, smooth or scabrous at apex, 1-2.5 mm diam. Leaves flat or carinate, relatively thin-textured, somewhat septate-nodulose, $1 / 2-3 / 4$ as long as culms, to $6 \mathrm{~mm}$ wide, bright yellow-green; midrib obvious abaxially, smooth or scabrous towards apex; marginal prickles sparse to dense, irregularly spaced $(0.3-1.4 \mathrm{~mm}$ apart), short

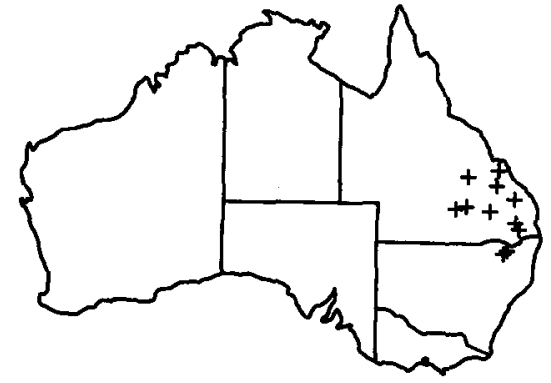

a

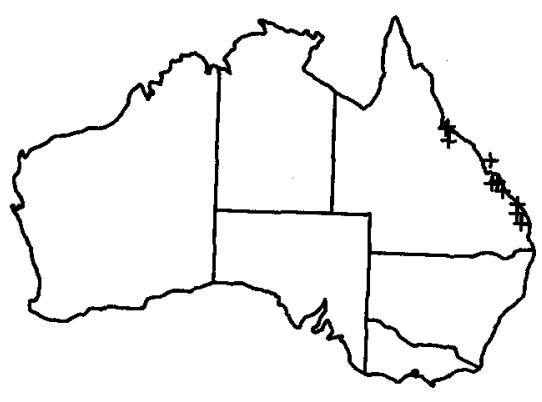

c 2

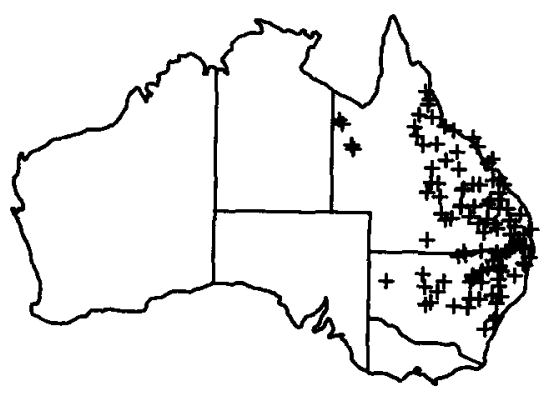

b $\square$

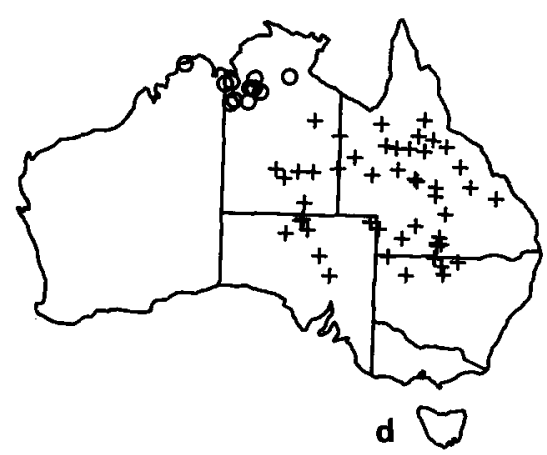

Figure 31. Distribution of: a, C. clarus; b, C. fulvus (New Guinea occurrence not mapped); c, C. perangustus; d, C. gilesii (crosses) and C. latzii (open circles). 
to long, $0.05-0.20 \mathrm{~mm}$ long, erect to antrorse and retrorse, occasionally flabellate, aculeate or rarely papillate; leaf sheaths \pm septate-nodulose, not smooth or shining, chestnut-brown. Inflorescence simple, 3-6 primary branches to $9.5 \mathrm{~cm}$ long; bracts erect when young, spreading nearly horizontally when mature, (1-)2-3 exceeding the inflorescence. Spikelets numerous in \pm dense subdigitate, \pm globose clusters of 1.5-3.5 cm diam.; spikelets compressed, oblong to narrow-ovate, 7-18 mm long, $3.0-4.5 \mathrm{~mm}$ wide in side view, 8-14(-20)-flowered; rachilla not thickened, not to broadly winged, wings to $0.1 \mathrm{~mm}$ wide; glume spacing $1.2-1.5 \mathrm{~mm}$; spikelet with rachilla persistent, glumes falling individually. Glumes elliptic or ovate, acute with excurved to \pm straight mucro $0.3-0.8 \mathrm{~mm}$ long, golden-brown to brown when old and dry, with green midrib, 2.5-4.0 mm long, 0.6-1.0 $\mathrm{mm}$ wide, sides 3-4-nerved, margins slightly inrolled and membranous. Anthers $0.3-1.1 \mathrm{~mm}$ long excluding appendage $<0.1 \mathrm{~mm}$ long. Nut trigonous, obovate with \pm obtuse to broad-acute apex, faces concave to flat, grey to nearly black (epidermal cells whitish over black body of nut), tuberculate, dull to glistening, $1.6-1.9 \mathrm{~mm}$ long, $1 / 2-2 / 3$ as long as glume, $0.6-0.8 \mathrm{~mm}$ wide, falling with glume or separately. Figure $30 \mathrm{~g}-\mathrm{i}$.

DisTRIBUTION: Central and south-eastern Queensland, extending to near Inverell on the North Western Slopes of New South Wales. Figure 31a. Ryves (1976) lists this as a wool-alien at Blackmoor Fruit Farm, $N$ Hants., England.

НАВІтAт: Apparently restricted to heavy soils derived from basalt; in grassland or open woodlands.

Blake's original description of C. clarus included immature specimens of C. alterniflorus with yellowish glumes (from Goyinga Mountains, Mootwingie and Oodnadatta).

C. clarus is most closely related to $C$. fulvus, with which it occasionally grows, differing in its generally broader spikelets and larger glumes, which are more evenly coloured yellow to dark golden-brown, in its nut surface and colour, and in its longer excurved glume mucro (although specimens of $C$. fulvus from northwestern Queensland have the mucro to $0.5 \mathrm{~mm}$ long). The leaves of $C$. clarus are darker (R.H.S. colour 144) and softer-textured than those of C. fulvus (R.H.S. colour 143). C. clarus also has some similarity to C. isabellinus (q.v.), but grows in a different habitat and shows various differences morphologically. C. clarus differs from C. gilesii and C. rigidellus in glume and nut shape, and in the prickles on the leaf and bract margins.

SELECTED SPECIMENS (25 examined): QUEENSLAND: Leichhardt: Minerva, N of Springsure, Blake 7934, Mar 1935 (BRI, K, MEL, NSW); Sandy Creek, c. $1.5 \mathrm{~km}$ S of Banana on Theodore road, Wilson et al. 3630, May 1981 (NSW). Burnett: Brian Pastures Experiment Station, -, May 1958 (BRI 9290). Darling Downs: Palardo, W of Miles, Blake 5886, May 1934 (BRI, CANB, MEL, NSW); $30 \mathrm{~km}$ SSE Toowoomba New England Highway, Latz 4590, Feb 1974 (NT); 4 km S of East Greenmount on Warwick-Toowoomba road, Wilson 4176, Dec 1981 (NSW, BRI, H, K, P); $8.5 \mathrm{~km}$ WSW of Westbrook on Pittsworth road, Wilson 4183, Dec 1981 (NSW). Maranoa: Mitchell, Maranoa R., Blake 5738, May 1934 (BRI, MEL). Warrego: Morven, Blake 11008, Apr 1936 (BRI, K, MEL, NSW, P). NeW SOUTH WALES: North Western Slopes: Delungra, Gidley NSW 65097, Jan 1962 (NSW); 2.6 km W of Graman-Oakwood road on Cherry Tree Hill - Delungra road, Wilson 4323, Jan 1982 (NSW); c. $4.5 \mathrm{~km}$ NE of Delungra on Graman road, Wilson 4326, Jan 1982 (NSW, P); 2 km S of Oakwood at Mt Russell turn-off, Wilson 6228, May 1985 (NSW); $2 \mathrm{~km} \mathrm{~N}$ of Bukkulla on Ashford road, Wilson 6218, May 1985 (NSW, BRI, NE, P).

\section{Cyperus fulvus $R$. Br.}

Brown (1810: 215); Poiret (1817: 187); Sprengel (1824: 226); Kunth (1837: 111); Steudel (1854: 53); Mueller (1874: 268), p.p.; Bentham (1878: 274), p.p. max.; Moore \& Betche (1893: 448); Bailey (1902: 1742); Kükenthal (1935-36: 456), p.p.; Kern (1974: 638); Cunningham et al. (1981: 160); Beadle et al. (1982: 606); Wilson (1987: 1136); Sharpe (1989: 
326, Figure 47L). Mariscus fulvus (R. Br.) C.B. Clarke (1908: 18); Clarke (1909: pl.30, Figure 7-8); Domin (1915: 443), p.p. max.

TyPE: QueENSLAND: East Coast, R. Brown (Bennett 5905); lecto BM (here designated); isolecto BM, BRI (fragm.).

Mariscus fulvus var. canescens C.B. Clarke ex Domin (1915: 444). C. fulvus var. canescens (Domin) Kükenthal (1935-36: 456). TYPE: QuEENSLAND: Kings Creek, Bowman, 1870; lecto $\mathrm{K}$ (here designated); probable isolecto $\mathrm{BM}, \mathrm{BRI}, \mathrm{K}, \mathrm{MEL}$.

Mariscus fulvus var. confusus C.B. Clarke ex Domin (1915: 444). C. fulvus var. confusus (Domin) Kük. (1935-36: 456); Blake (1954: 237). TYPE: QuEENSLAND: Gracemere, $O$ 'Shanesy; lecto $\mathrm{K}$ (here designated; mounted on same sheet as 'Richmond River, Dangar' and 'near Tenterfield, Stuart'); isolecto BRI.

Mariscus fulvus var. densispiculatus Domin (1915: 444). C. fulvus var. densispiculatus (Domin) Kükenthal (1935-36: 457). TYPE: QueEnsland: Pentland, Domin; holo PR, n.v.

C. fulvus var. viscidus Kükenthal (1935-36: 456). TYPE: New SOUTH WALES: Warrumbungle Ranges, Forsyth; lecto NSW 22703, sent to Kükenthal as 'No. 73' (here designated); isolecto BRI.

C. gracilis R. Br. var. rigidellus Bentham (1878: 266), as '?rigidella', p.p. ('head of Boyd River, Leichhardt', MEL 92161).

C. laetus C.B. Clarke (1908: 9); Domin (1915: 435); nec Presl (1828) nec Kunth (1837) nec Ridley (1884). TYPE: QUEENSLAND: Gracemere, O'Shanesy; lecto K (here designated); isolecto BRI, ?MEL.

Mariscus fulvus var. jucundus Domin (1915: 444). TYPE: QuEENSLAND: Gracemere, O'Shanesy; holo K; iso BRI, MEL. [Same type as C. laetus C.B. Clarke]

C. ochroleucus Boeckeler (1875: 85); Kükenthal (1935-36: 481); Blake (1940: 43). TYPE: QuEENSLAND: Lake Elphinstone, Dietrich s.n.; holo B, as 'Dietrich 591' fide Blake; n.v.

C. sieberi Kunth (1837: 96); Steudel (1854: 51); Boeckeler (1868: 608), (1875: 84); Clarke (1884: 142). Type: New South Wales: Nova Hollandia, Sieber 630; holo B, ex hb. Kunth; iso $B, G, L$.

[C. alterniflorus auct. non R. Br.: Bentham (1878: 275), p.p. min.; Bailey (1902: 1742), p.p.; (O'Shanesy, Gracemere).]

[C. carinatus auct. non R. Br.: Bentham (1878: 274), p.p. (Queensland and New South Wales specimens); Moore \& Betche (1893: 448), p.p.; Bailey (1902: 1742), p.p.]

Slender perennial, tufted with bases sometimes subbulbously thickened, $25-50(-80) \mathrm{cm}$ high, occasionally viscid. Culms trigonous or triquetrous (at least above), often terete below, smooth or scabrous, 0.9-2.5 mm diam. Leaves flat or carinate, often somewhat thickened, straight or somewhat curly, usually septate-nodulose, $2 / 3$ the length of to slightly exceeding the culms, to $6(-9.5) \mathrm{mm}$ wide, dull yellow-green; midrib \pm obvious abaxially, smooth or scabrous; marginal prickles dense to very sparse, mostly irregularly spaced $(0.1-2.0 \mathrm{~mm}$ apart), long to short, $0.05-0.25(-0.7) \mathrm{mm}$ long, strongly flabellate to erect aculeate (and then margins often with very short scabrosities as well), or antrorsely aculeate; leaf sheaths not septate-nodulose, not smooth or shining, yellowish or stramineous with occasional red-brown blotches. Inflorescence simple or small-compound, $3-8(-10)$ primary branches to $7(-10) \mathrm{cm}$ long; bracts erect to spreading, (1-)2-3(-6) exceeding the inflorescence. Spikelets $10->15$ in dense, spicate, hemispherical to globose clusters of $1.5-3(-4) \mathrm{cm}$ diam.; spikelets compressed, oblong, 6-15(-30) $\mathrm{mm}$ long, 2.0-3.5 mm wide in side view, 8-20(-36)-flowered; rachilla not thickened, not to broadly winged, wings to $0.2 \mathrm{~mm}$ wide; glume spacing $1.2-1.8(-2.0) \mathrm{mm}$; spikelet with rachilla persistent and glumes falling individually. 
Glumes elliptic, broad-acute with straight mucro $0.1-0.3(-0.5) \mathrm{mm}$ long, stramineous or golden-brown with dull red-brown blotches and a green midrib, $2.0-3.0 \mathrm{~mm}$ long, $0.6-0.9(-1.3) \mathrm{mm}$ wide, sides 2-4-nerved, margins inrolled and hyaline to membranous. Anthers $0.5-1.2 \mathrm{~mm}$ long excluding appendage $\leq 0.1 \mathrm{~mm}$ long. Nut trigonous (generally with the angles very rounded), obovate to broad-elliptic with broad-acute apex, faces convex to flat, yellow-brown, colliculate to smooth and reticulate-areolate, shining, $1.5-2.0 \mathrm{~mm}$ long, $7 / 8$ as long as to equalling the glume, $0.6-0.9 \mathrm{~mm}$ diam., falling with glume. Figure $32 a-c$.

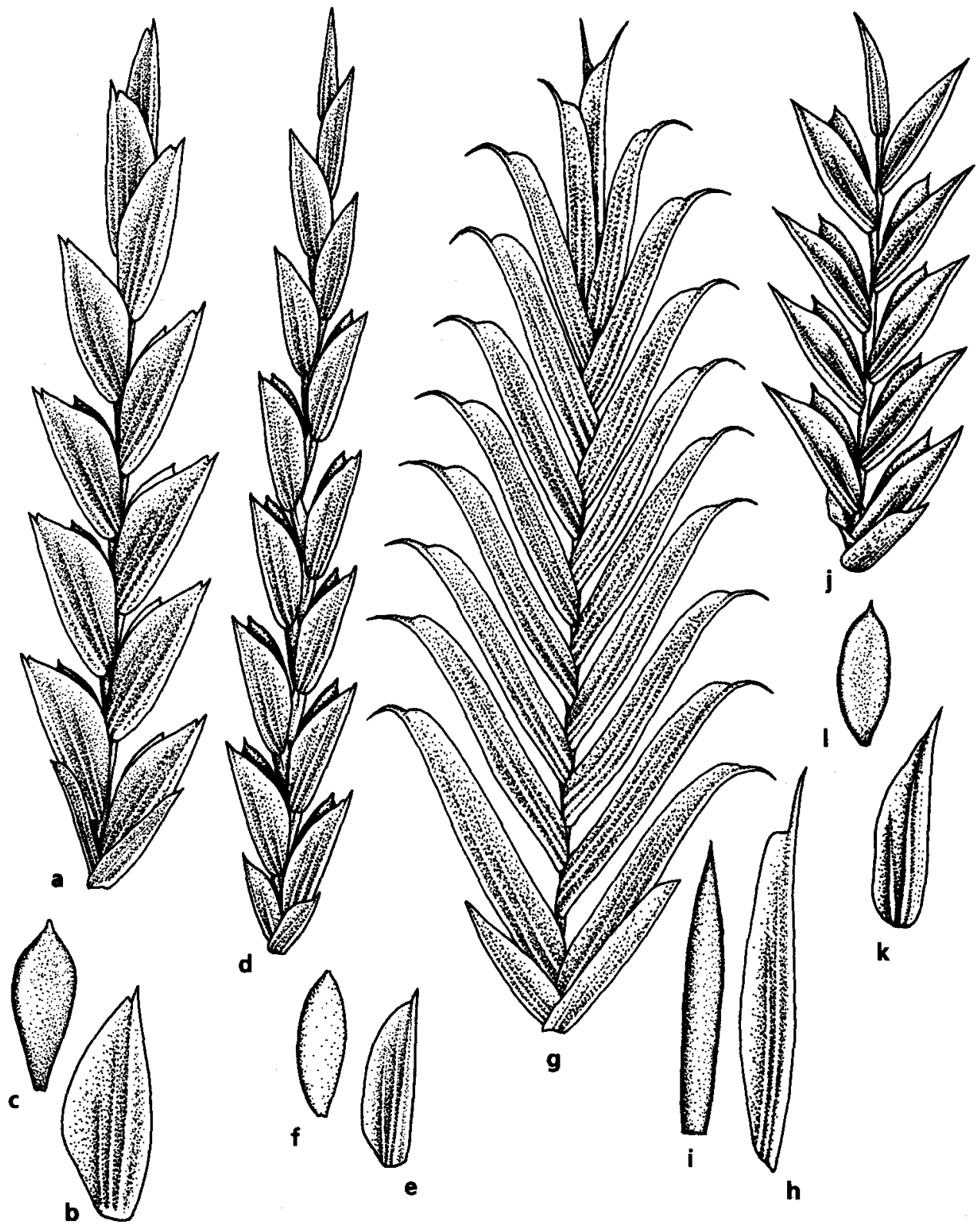

Figure 32. Spikelet details. C. fulous: a, spikelet; b, glume; $\mathbf{c}$, nut. C. perangustus: d, spikelet; $\mathbf{e}$, glume; f, nut. C. gilesii: $\mathbf{g}$, spikelet; $\mathbf{h}$, glume; $\mathbf{i}$, nut. C. latzii: $\mathbf{j}$, spikelet; $\mathbf{k}$, glume; $\mathbf{l}$, nut. a-c from Coveny 2475; d-f Blake 11304; g-i Mills \& Cox 23; j-1 Dunlop 3549. a, d, g, jX 11; b, c, e, f, h, i, k, 1 X 14. 
DistRIBUTION: Widespread in Queensland and New South Wales; also in southern New Guinea. Figure 31b. Probst (1949) lists this species as a wool-alien at Derendingen, Switzerland, in 1930. Ryves (1976) may be referring to this species when he records the tropical species $C$. sporobolus as a wool-alien at Blackmoor, England.

HABITAT: Sandy to loam soils; generally in open woodland or forest, often associated with a grassy understorey, over a wide latitudinal range (dominant tree species in the various regions include Eucalyptus melanophloia, E. polycarpa s.lat., E. populnea, E. maculata, E. tereticornis, E. crebra, Callitris glaucophylla and Angophora leiocarpa). Occasionally on coastal cliffs, in inland rocky gullies, along drainage lines around rock outcrops. On sandy riverbanks or in floodways in NW Queensland (and very occasionally so in other regions).

C. fulvus is a variable species, as will be seen from previous attempts to recognise varieties. However, the variation does not fall into clear patterns and is not recognisable taxonomically (on current knowledge). For example, strongly viscid specimens tend to have large, flabellate marginal prickles on the leaves and are generally slender plants, but these features are also seen (not united) in other non-viscid specimens. As Blake (1940) wrote, about var. densispiculatus: 'The taxonomic value of this variety is questionable, as in most tufts seen with reflexed secondary rays in the inflorescence, some inflorescences occur without such rays. In other words, C. fulvus (typical) and var. densispiculatus may occur on the same plant. The species is an exceedingly variable one!'

Specimens from north-western Queensland tend to have broader rachilla wings (to $0.2 \mathrm{~mm}$ wide), narrower glumes with more acute apex and a longer mucro $(0.2-0.5 \mathrm{~mm}$ long) and a nut that is often much shorter relative to the glume. This form grows in seasonally wet situations, on banks of streams and waterholes. It would be possible to recognise this form as a subspecies, but it is undesirable to do so since it would leave a heterogeneous residue.

C. fulvus is closely related to C. clarus (q.v.) and C. perangustus (q.v.). It differs from C. gilesii in the shape and size of the glumes and nuts and also in the prickles on the leaf margins. There is a superficial resemblance between $C$. fulvus and depauperate specimens of $C$. carinatus (q.v.). Similarly, very large specimens of $C$. fulvus have been mistaken for $C$. alterniflorus, but the two species differ in most characters if one compares descriptions. The leaves of $C$. fulvus are more blue-green than those of C. alterniflorus. O'Shanesy 1698, 1699 (MEL 92162, 92155) are very robust plants that could be confused with $C$. alterniflorus, but the nut and marginal prickles are typical for $C$. fulvus.

The name C. fulvus was applied rather indiscriminately in the past. Thus, Mueller \& Tate (1890) and Mueller in Tate (1896) named a specimen of C. betchei subsp. commiscens as this ('Tietkens, Glen Helen'). Similarly, Fitzgerald (1918) used C. fulvus for a specimen of $C$. ixiocarpus; several other specimens ('Fitzgerald, Lennard, May and Fitzroy Rivers') listed under that name in that publication have not been seen. A few specimens listed under C. fulvus by Kükenthal (1935-36) have not been seen by me ('Kempe 459, Finke River; Giles, zwischen Youldeh und Elizabeth; C.W. Nyalasy, Kimberley-Distrikt'). These are all unlikely to be this species (unless the localities have been stated wrongly).

SeleCted SPECIMENS (280 examined): QueENSLAND: Cook: Brooklyn Station, Flecker 7288, Feb 1941 (CANB). Burke: Mt Emu Plains Station, Hubbard \& Winders 7542, Feb 1931 (K, BRI); Little Creek, 19 km NW of Riversleigh HS., Wilson 5545, May 1983 (NSW, BRI). North Kennedy: 20 miles [32 km] N of Conjuboy Station, Lazarides 4199, Feb 1954 (CANB, AD, BRI, K, MEL, NSW, NT, PERTH). South Kennedy: 3 miles [5 km] NE of Cerito Station, Adams 966, May 1964 (CANB, BRI, K). Gregory North: $22 \mathrm{~km} \mathrm{~N}$ of Wills Creek on Mt Isa road, Wilson 5457, May 1983 (NSW). 
Mitchell: $10 \mathrm{~km}$ E of Birkhead, Boyland 7016, Mar 1974 (BRI, NSW, NT). Leichhardt: Sandy Creek, c. $1.5 \mathrm{~km}$ S of Banana, Wilson et al. 3632, May 1981 (NSW). Port Curtis: near Rockhampton, Mt Beserker, Blake 12723, Mar 1937 (BRI, CANB, K, NSW). Wide Bay: Wonbah turn-off, 15.5 km NE of Mt Perry, Wilson \& Sharpe 3757, May 1981 (NSW, BRI). Burnett: Narayan, Pedersen N185, Apr 1972 (BRI); just outside boundary of Wuruma Dam, Wilson $\&$ Sharpe 3744, May 1981 (BRI, H, K, NSW, P). Moreton: Petrie, Blake 1447, Jan 1933 (K, MEL, NSW). Darling Downs: near Gurulmundi, near Wandoan, Hubbard 5144, Nov 1930 (K, BRI). Maranoa: SE of Surat, Thomby Range, Blake 21301, May 1960 (BRI, K, NSW). Warrego: Charleville, Blake 5322, Apr 1934 (BRI, NSW, NT). NEW SOUTH W WLES: North Coast: Bundjalung National Park, $3 \mathrm{~km}$ N of Black Rocks, Griffith NE B9, May 1982 (NSW). Central Coast: junction of Jocks Creek and Wollondilly R., Covery et al. 6080, Mar 1975 (NSW, BRI, CHR, K, P). Northern Tablelands: Chandlers Peak, Guyra, Boorman, Mar 1917 (NSW 22705, BM, BRI, K). Central Tablelands: Jenolan Caves district, Blakely, 1900 (NSW 22702, BRI, K). North Western Slopes: $9 \mathrm{~km} \mathrm{~N}$ of Baradine on Kenebri road, Payne \& Jacobs 1, Jan 1976 (NSW, BRI, K, L, P, US). Central Western Slopes: $12.7 \mathrm{~km}$ WNW of Scone P.O. on Bunnan road, Coveny et al. 5884, Nov 1974 (NSW, BRI, CHR, K, L, P, TNS, US). North Western Plains: $2 \mathrm{~km}$ SW of Jomara, $4 \mathrm{~km}$ NE of Boora, Wilson 1770, Mar 1978 (NSW, BRI, CHR, K, L, P). South Western Plains: Warranary Hills, c. $5 \mathrm{~km}$ direct WNW of Roto, Wilson \& Murray 5893, Mar 1984 (NSW, AD, MEL, P). North Far Western Plains: Mootwingee, between camping area and Snake Cave, Briggs 2751, May 1969 (NSW). New GuINEA: PaPua New GuINEA: Quaipo [Kuaipo], McGregor, 1889 (MEL).

30. Cyperus perangustus S.T. Blake

Blake (1940: 43), authors given as '(Kükenth.) S.T. Blake'; Sharpe (1989: 324, Figure 47G).

TYPE: QuEENSLAND: Wide Bay: near Bundaberg, S.T. Blake 11304, 26 Apr 1936; holo BRI; iso $K$, MEL, NSW.

[C. angustatus auct. non R. Br.: Bentham (1878: 282), p.p.; Bailey (1902: 1746), p.p.; Kükenthal (1935-36: 452), p.p. Mariscus angustatus auct. non (R. Br.) C.B. Clarke: Domin (1915: 444), p.p. (Bowman and $O^{\prime}$ Shanesy specimens)]

Slender perennial, tufted, $45-95 \mathrm{~cm}$ high, spikelets occasionally somewhat viscid. Culms triquetrous to trigonous, usually strongly antrorsely scabrous above, 1-2.5 mm diam. Leaves flat or carinate, septate-nodulose, $1 / 2-2 / 3$ as long as culms, to $4.5 \mathrm{~mm}$ wide; midrib obvious abaxially, scabrous; leaf margins dense or occasionally sparse, regularly spaced (0.1-0.6 mm apart), long to short, 0.1-0.2 $\mathrm{mm}$ long, strongly antrorse, aculeate; leaf sheaths \pm septate-nodulose, not smooth and shining, stramineous. Inflorescence small-compound, 4-7(-11) primary branches to $8 \mathrm{~cm}$ long; bracts erect to spreading, 2-3(-5) exceeding the inflorescence. Spikelets few (c. 4-10) in obviously spicate, hemispherical to short-cylindrical clusters of $1.5-3 \mathrm{~cm}$ diam.; spikelets compressed, oblong, 5-18 mm long, 1.5-2 mm wide in side view, 4-16(-22)-flowered, occasionally somewhat viscid; rachilla not thickened, not to broadly winged, wings to $0.1 \mathrm{~mm}$ long; glume spacing 1.4-1.7 mm; spikelet falling as a unit, or rachilla persistent and glumes falling individually. Glumes elliptic, acute, with straight mucro $<0.1-$ $0.2 \mathrm{~mm}$ long, dark golden-brown, with a narrow green midrib, 1.7-2.2(-2.6: Dallachy 261) $\mathrm{mm}$ long, $0.5-0.7 \mathrm{~mm}$ wide, sides $2-3(-4)$-nerved, margins very narrow-membranous and not or only slightly inrolled. Anthers $0.3-0.7 \mathrm{~mm}$ long excluding appendage $<0.1 \mathrm{~mm}$ long. Nut trigonous, narrow-obovate with broad-acute to obtuse apex, faces flat to convex, pale red-brown, small-colliculate or foveate or smooth and reticulate-areolate, glistening to shining, $1.3-1.5 \mathrm{~mm}$ long, $7 / 8$ as long as to equal to glume, $0.5-0.6 \mathrm{~mm}$ diam., falling with glume or separately. Figure $32 \mathrm{~d}-\mathrm{f}$.

DisTRIBUTION: Eastern coast of Queensland, from Townsville to Rockhampton. Figure 31c.

HABITAT: Loamy or sandy soils; open forest or woodland sites near coast. 
In publishing this species, Blake (1940) wrote that Kükenthal mentioned in correspondence that he thought this taxon could be treated as ' $C$. fulvus $\mathrm{R}$. Br. var. perangustus Kük.' However, Kükenthal did not actually publish this variety, so the author of the species should be given as just 'S.T. Blake'.

C. perangustus is closely related to $C$. fulvus but can be distinguished by its leaf margins, its more slender spikelets and glumes, and the nut shape and colour. These two species have their spikelets in more obviously spicate clusters than most other species. The leafy bracts subtending the ultimate branches of the inflorescence in C. perangustus are no longer than in C. fulvus (or indeed in most other species) but they appear more obvious because of the slender spikelets and the persistence of the bracts after the spikelets fall.

In the past, specimens of this species were sometimes labelled as C. angustatus (for example, 'Bowman, Kings Creek' (K) was so-labelled by Bentham), but that species is rhizomatous. It differs further in the leaves, which have the midrib not obvious abaxially, and sparse and irregularly spaced marginal prickles, and in the subdigitate spikelet clusters.

Dallachy 261 from Rockhampton differs from other specimens in having completely smooth culms and large glumes c. $2.6 \mathrm{~mm}$ long.

SelECTED SPECIMENS (24 examined): QuEENSLAND: Cook: Barrabas Scrub, Dockrill 526, May 1972 (BRI). North Kennedy: Magnetic I. near Townsville, Blake 8237, Mar 1935 (BRI, MEL), Blake 8249, Mar 1935 (BRI, K, NSW); Townsville, Castle Hill, Blake 8359, Mar 1935 (BRI, K); James Cook University, Douglas Campus, Townsville, Seary and Graham S-5296, (JCT); Shelley Beach, Townsville, Wells S-3967, Feb 1971 (JCT). Port Curtis: Marmor, between Rockhampton and Gladstone, Blake 12778, Mar 1937 (BRI, MEL, NSW); Rockhampton, on W side of river, Dallachy 261, Jan 1863 (MEL, BRI); Pine Islet, Northumberland Group, Heatwole, Feb 1971 (BRI 146121); near Bluff Rock, Middle Percy I., Lazarides 5658, Apr 1956 (BRI, CANB, K); Beecher near Gladstone, McLachlan 14, May 1933 (BRI); Gracemere, O'Shanesy 1414, Nov 1873 (MEL), O'Shanesy 1642, Feb 1879 (MEL); Yeppoon, $40 \mathrm{~km}$ NE of Rockhampton, Sharpe 2360, June 1978 (BRI, NSW), Wilson et al. 3670, May 1981 (NSW, BRI, P). Wide Bay: Imbil, Blake 14616, June 1942 (BRI); North Aramara, Blake 19259, Mar 1954 (BRI, NSW).

\section{Cyperus gilesii Benth.}

Bentham (1878: 274); Tate (1890: 181); Bailey (1902: 1741); Domin (1915: 430); Ewart \& Davies (1917: 55); Black (1922: 89), (1943: 145), (1978: 263); Kükenthal (1935-36: 453); Wilson (1981a: 507, Figure 638E); Cunningham et al. (1981: 160).

TYPE: Northern Territory: Charlotte Waters, E. Giles; lecto K (here designated); isolecto MEL (as 'Giles 20').

Slender annual or short-lived perennial, tufted, shallow-rooted, $10-35(-50) \mathrm{cm}$ high, not viscid. Culms trigonous or triquetrous, smooth, $0.8-2 \mathrm{~mm}$ diam. Leaves flat or carinate, \pm septate-nodulose, c. $1 / 2$ as long as the culms, to $4.5 \mathrm{~mm}$ wide; midrib obvious abaxially, smooth or scabrous towards apex; marginal prickles sparse, irregularly or regularly spaced $(0.2-0.8 \mathrm{~mm}$ apart), short, $0.05-0.10 \mathrm{~mm}$ long, erect, papillate or rarely aculeate; leaf sheaths not septate-nodulose, smooth, \pm shining, salmon-pink, at base the margins white-membranous. Inflorescence simple, 1-5 primary branches to $6.5 \mathrm{~cm}$ long; bracts erect to spreading or deflexed, usually not septate-nodulose, 1-3 exceeding the inflorescence. Spikelets usually numerous in subdigitate, \pm dense, hemispherical to globose clusters of $1.5-5 \mathrm{~cm}$ diam.; spikelets compressed, oblong, $10-30 \mathrm{~mm}$ long, $2.5-4.5 \mathrm{~mm}$ wide in side view, 8-34-flowered; rachilla not thickened, not to broadly winged, wings to $0.1 \mathrm{~mm}$ wide; glume spacing $1.0-1.5 \mathrm{~mm}$; spikelet falling as a unit, or rachilla persistent and glumes falling 
invididually. Glumes very narrow-elliptic to narrow-ovate, retuse or acute with usually excurved mucro $0.3-1.0 \mathrm{~mm}$ long, golden-brown to red-brown with green midrib, 3.0-5.0 mm long, 0.5-0.8 mm wide, sides 2-3-nerved, margins inrolled and narrow-membranous. Anthers $0.3-0.6 \mathrm{~mm}$ long excluding appendage $<0.1 \mathrm{~mm}$ long. Nut trigonous, very narrow-elliptic with acute to acuminate apex, faces flat, red-brown to grey-brown (epidermal cells whitish over black body of nut), tuberculate to smooth and reticulate-areolate, glistening, 2.0-2.5 mm long, $2 / 3-3 / 4$ as long as glume, $0.3-0.5$ $\mathrm{mm}$ diam., falling with glume. Figure $32 \mathrm{~g}-\mathrm{i}$.

Distribution: Scattered in Central Australia, Queensland, NW New South Wales, and South Australia. Figure 31d. Probst (1949) records this species as a wool-alien at Derendingen, Switzerland, in 1915 and 1917.

HABITAT: Sandy loam to clay soils; in ephemerally wet situtations (banks of creeks and waterholes, gilgais, on claypans, depressions in grassland, roadside drains).

The lectotype is immature, whereas the other specimen cited by Bentham (Mitchell district, herb. Mueller, -, MEL) has mature nuts in the spikelets. However, Bentham's script appears only on the Giles specimen (K) and this is therefore chosen as the lectotype since it is the only specimen definitely seen by Bentham.

C. gilesii is distinctive in its combination of the following characters: more or less oblong glumes with a generally long excurved mucro, papillate leaf margins, and long narrow nut. It shows some similarity to C. clarus (q.v.) and to C. fulvus (q.v.). It has papillate (or occasionally aculeate) leaf marginal prickles similar to those of C. rigidellus but it can be distinguished from that species by its nut and glume shape, its smooth culms, and its leaves and bracts, which are softer in texture and less curly.

Koch 494 (B), which belongs here, was cited by Kükenthal under C. dactylotes.

Selected specimens (84 examined): QueEnsLand: Cook: Spring Creek, Simonett, July 1950 (BRI). Burke: Chudleigh Park Station 110 miles $[175 \mathrm{~km}] \mathrm{N}$ of Hughenden, Hubbard $\mathcal{E}$ Winders 7642 , Feb 1931 (K, BRI). North Kennedy: 11 miles [18 km] E of Lolworth on Amara road, Carolin 8415, Apr 1974 (SYD). South Kennedy: 1 mile [1.5 km] E of Dooruna Station, Adams 1256, Aug 1964 (CANB, BRI). Gregory North: Pigeon Creek, $50 \mathrm{~km}$ NW of Dajarra on Mt Isa road, Wilson 5473, May 1983 (NSW, BRI). Mitchell: Prairie, Hubbard \& Winders 7090, Feb 1931 (K, BRI, G). Leichhardt: $1 \mathrm{~km}$ ESE of Nogoa R. at Emerald on Capricorn Highway, Wilson et al. 3594, May 1981 (NSW, BRI, H, K, P). Warrego: Gilruth Plains, Cunnamulla, Allen 596, Mar 1947 (CANB, NE), McKee 10288, Apr 1963 (BRI, NSW). Gregory South: $7 \mathrm{~km} \mathrm{E}$ of Toona Gate towards Warri Gate, Wilson $\mathcal{E}$ Pickard 1664, Nov 1976 (NSW, BRI, K, P). New South WALES: North Western Plains: 25 miles [40 km] N of Bourke on N Collerina road, Milthorpe \& Cunningham 1725, Mar 1974 (NSW, P). North Far Western Plains: $12 \mathrm{~km}$ S of Warri Gate on Tibooburra road, Briggs \& Seur 5409, Sep 1974 (NSW, BRI, K). NORTHERN TERRITORY: Barkly Tableland: 7 miles [11 km] W Armchair Bore, Brunette Downs, Chippendale 1972, Mar 1956 (NT, AD, BRI, CANB, MEL, NSW, PERTH). Central North: MacDonald Downs, Latz 5816, Oct 1974 (NT, BRI, NSW). Central South: Yambah Station, Burt Plain, Latz 5955, May 1975 (NT); Andado Station, Latz 6779, Apr 1977 (NT, AD, BRI, K). South Australia: Flinders Ranges: Mt Lyndhurst, Koch 494, Mar 1900 (B, DBN, K, NSW). Gairdner-Torrens: c. 17 km N of Bosworth Station HS., Lake Torrens, Swinbourne 114, Sep 1968 (AD). Lake Eyre: $13 \mathrm{~km} \mathrm{~N}$ of Wintinna Creek, Beauglehole 44392, May 1974 (NSW, NT); 5 miles [8 km] N of Cordillo Downs, Filson 3395, Oct 1960 (AD, NSW).

\section{Cyperus latzii K.L. Wilson, sp. nov.}

$\mathrm{Ab}$ speciebus aliis Sectionis Pinnatorum glumis latiore carinatis patentibusque differt.

TYPE: NORTHEN TERRITORY: Victoria River: Armstrong River crossing, Wave Hill-Top Springs road, K.L. Wilson 4741, 21 Apr 1983; holo NSW; iso BRI, CANB, K, L, NT, NY, P, PERTH. Figure 29b. 
More or less slender annual or perennial, tufted, shallow-rooted, 30-50 cm high, not viscid. Culms \pm trigonous to terete below, smooth, $1.2-2 \mathrm{~mm}$ diam. Leaves flat or carinate, usually not septate-nodulose, $\leq$ culms, to $4 \mathrm{~mm}$ wide, pale yellow-green; midrib \pm obvious, smooth or scabrous towards the apex; marginal prickles dense to sparse, irregularly spaced (0.1-0.7 mm apart), short, c. $0.05 \mathrm{~mm}$ long, flabellate to erect, papillate or occasionally aculeate; leaf sheaths not septate-nodulose, striate, not shining, pinkish brown, thin-textured. Inflorescence small-compound to compound, occasionally simple, spreading, 5-8 primary branches to $8 \mathrm{~cm}$ long; bracts suberect to spreading, 2-4 exceeding inflorescence. Spikelets 8-15 in subdigitate, loose, hemispherical to globose clusters of 1-1.5(-2) cm diam.; spikelets compressed, oblong, 5$11(-17) \mathrm{mm}$ long, 1.8-4.0 mm wide in side view, (4-)6-12(-20)-flowered; rachilla may be thickened at maturity (to $0.15 \mathrm{~mm}$ thick), not to narrowly winged, wings to 0.05 mm wide; glume spacing 1.0-1.5 mm; spikelet falling as a unit, or rachilla persistent (perhaps only if plants are collected before senescence). Glumes narrow-ovate to elliptic, long-acute with \pm straight mucro $0.1-0.2 \mathrm{~mm}$ long (whole glume somewhat excurved), yellow to red-brown at maturity (with quite bright yellow blotches when young), with broad green midrib, 1.8-2.3(-2.7) $\mathrm{mm}$ long, 0.5-1.0 mm wide, sides (1-)2(-3)-nerved with nerves often prominent and white, margins not inrolled but spreading widely at maturity and very narrowly hyaline. Anthers $0.6-1.1 \mathrm{~mm}$ long excluding appendage $0.2-0.5 \mathrm{~mm}$ long. Nut trigonous, narrow-obovate to narrowelliptic with \pm broad-acute apex, faces flat to convex, pale brown to dark red-brown, small-foveate to small-colliculate, glistening to shining, $1.2-1.6 \mathrm{~mm}$ long, $2 / 3-3 / 4$ as long as glume, 0.4-0.6 mm diam., falling separately from glume. Figure $32 \mathrm{j}-\mathrm{I}$.

Distribution: From the Kimberley region of Western Australia to the Darwin \& Gulf region, Northern Territory. Figure 31d.

HaBiTAT: Sandy loam or clay soils; in seasonally wet situations on levees and in gravelly creek-beds and around depressions in grassland.

The species is named after Mr Peter Latz of Alice Springs, who has studied and made extensive collections of Cyperaceae throughout the Northern Territory.

Distinctive in this Section by its spreading glumes, which have a very broad midrib (about half the width of the glume) with a strong nerve separating the midrib and the glume sides. The midrib is most obvious in younger plants when it is bright green, contrasting with the yellow-brown glume sides. At maturity the glumes are a fairly uniform dull brown, with the midrib distinguished by being thicker-textured than the sides. It occasionally grows with $C$. viscidulus, which differs in being a taller, slender perennial, with rather viscid spikelets that are generally narrower but with more flowers.

SPECIMENS EXAMINED: NoRTHERN TERRITORY: Darwin and Gulf: $\mathrm{N}$ of Nutwood Downs HS., near Kempsey Creek, Blake 17563, May 1947 (BRI). Victoria River: Top Springs-Victoria R. Downs road, Middle Creek, Beauglehole 54564, July 1976 (NT); Duncan Highway, $1.5 \mathrm{~km}$ S of Katherine-Wyndham road, Beauglehole 51295, 51299, May 1976 (NT); Saddle Creek, 22.9 miles [37 km] E Newry, Chippendale 5989, May 1959 (NT, BRI); Limbunya, Dunlop 3549, May 1974 (NT, BRI, CANB, NSW); Farquharsen Gap, Latz 5372, June 1974 (BRI, K, NSW ex NT, PERTH); Montejinni Station, Latz 5270, June 1974 (NSW); $50 \mathrm{~km}$ NNW of Inverway HS., Latz 5415, June 1974 (NSW, PERTH); Wave Hill area, Stroder, Mar 1971 (BRI 119346); 38 km NW of Top Springs Roadhouse on Victoria River Downs road, Wilson 4753, Apr 1983 (NSW, AD, BRI, DNA, H, K, P, PERTH); c. $18 \mathrm{~km} \mathrm{~N}$ of Victoria River Downs HS, on Timber Creek road, Wilson 4763, Apr 1983 (NSW); Victoria Highway, $27.6 \mathrm{~km}$ NE of Victoria R. Crossing, Wilson 4902, Apr 1983 (NSW, AD, CANB, DNA). Western Australia: Gardner: Ord R., Durack, May 1945 (PERTH); Caravan Creek, near Port Warrender, Mitchell Plateau, Hnatiuk MP 118, MP 119, June 1976 (PERTH). 


\section{Excluded name}

C. inornatus Boeckeler (1875: 86) = C. nutans Vahl var. eleusinoides (Kunth) Haines, synon. nov.

TYPE: Port Mackay, A. Dietrich 2595 ( $h b$. Godeffroy 661), 1866-69; holo ?; probable iso B, L (both ex HBG).

This was tentatively put in the synonymy of C. gunnii subsp. novae-hollandiae by Kükenthal (1935-36). However, the two probable isotypes in B and L are referable to C. nutans var. eleusinoides. No specimens annotated by Boeckeler have been located. Both specimens seen are recent accessions from $\mathrm{HBG}$, with typewritten labels, and it would be inappropriate to choose either of them as lectotype without checking further for replicates of that collection with original labels.

\section{Acknowledgments}

This paper is based on a study of Cyperus section Pinnati submitted as an M.Sc. thesis to the University of New South Wales in 1986. That in turn arose from a separate collaborative study (unpubl.) with Lawrie Johnson on generic limits in tribe Cypereae. My discussion of relationships of section Pinnati within the genus is produced from a background of our joint discussions and deliberations. My period in 1977 on a French Government scholarship at the Laboratoire de Phanérogamie, Muséum National d'Histoire Naturelle, Paris, enabled me to extend the range of Cyperus species examined. Jeffrey Harborne and Christine Williams of Reading University kindly analysed a sample of one species of section Glutinosi, C. oxylepis, whilst analysing Australian species. My thanks go to the numerous curators of herbaria who sent specimens on loan or provided me with facilities when visiting their institutions. I would also like to thank David Mackay for his drawings of spikelet features and leaf prickles, and Anna Farnham and Louisa Murray for the drawings of leaf and culm anatomy. Ms Murray also prepared the initial version of the species concentration map. Dianne Godden helped prepare the illustrations for publication. Liz Norris and Peter Richards took a large proportion of the SEM micrographs of species of this Section on our R.B.G. ISI-40 machine. My thanks also to Derek Anderson and Mel Dickson (Univ. New South Wales) for allowing me to use the Cambridge Stereoscan S4-10 in the Biomedical Electron Microscope Unit to examine species of Cyperus sens. lat., including sect. Pinnati. Bryan Barlow kindly made available to me his paper on natural regions of Australia while still in proof stage, and later lent me the original of his revised map. Chris Quinn, Surrey Jacobs, Lawrie Johnson, Barbara Briggs, Paul Goetghebeur, Roger Carolin, Peter Wilson, and my husband, Alastair Wilson, have given advice and help in various ways, for which I am most grateful. 


\section{References}

Allan, R.D., Correll, R.L., \& Wells, R.J. (1969) A new class of quinones from certain members of the family Cyperaceae. Tetrahedron Letters 53: 4669-4672.

Allan, R.D., Wells, R.J., Correll, R.L., \& MacLeod, J.K. (1978) The presence of quinones in the genus Cyperus as an aid to classification. Phytochemistry 17: 263-266.

Bailey, F.M. (1902) The Queensland flora, part 6 (Diddams \& Co.: Brisbane).

Barlow, B.A. (1986) A revised natural regions map for Australia. Brunonia 8: 387-392.

Beadle, N.C.W., Evans, O.D., \& Carolin, R.C. (1982) Flora of the Sydney region, edn 3 (Reed: Sydney).

Bentham, G. (1878) Flora Australiensis, vol. 7.

Black, J.M. (1922) Flora of South Australia, part 1 (Govt Printer: Adelaide).

Black, J.M. (1924) Additions to the flora of South Australia No. 22. Trans. \& Proc. Roy. Soc. South Australia 48: 253-257.

Black, J.M. (1929) Flora of South Australia, part 4 (Govt Printer: Adelaide).

Black, J.M. (1943) Flora of South Australia, edn 2, part 1 (Govt Printer: Adelaide).

Black, J.M. (1978) Flora of South Australia, edn 3, part 1 (Govt Printer: Adelaide).

Blackall, W.E., \& Grieve, B.J. (1954) How to know Western Australian wildflowers, part 1 (Univ. Western Australia: Perth).

Blake, S.T. (1940) Notes on Australian Cyperaceae III. Proc. Roy. Soc. Queensland 51: 32-50.

Blake, S.T. (1943) Critical notes on the Gramineae and Cyperaceae of South Australia with descriptions of new species. Trans. Roy. Soc. South Australia 67: 42-61.

Blake, S.T. (1947a) Notes on Australian Cyperaceae VII. Proc. Roy. Soc. Queensland 58: 35-50.

Blake, S.T. (1947b) The Cyperaceae collected in New Guinea by L.J. Brass, II. J. Arnold Arbor. 28: 207-229.

Blake, S.T. (1954) The Cyperaceae collected in New Guinea by L.J. Brass, IV. J. Arnold Arbor. 35: 203-238.

Boeckeler, O. (1868-1874) Die Cyperaceen des Königlichen Herbariums zu Berlin. Linnaea 35: 397-512 (1868); Linnaea 36: 271-512 (1870); Linnaea 38: 223-256 (1874).

Boeckeler, O. (1875) Ein Beitrag zur Kenntniss der Cyperaceen-Flora Neuholland's und einiger polynesischer Inseln. Flora 58: 81-89, 107-112, 116-123.

Boeckeler, O. (1884) Neue Cyperaceen. Bot. Jahrb. 5: 497-521.

Briggs, B.G., \& Johnson, L.A.S. (1979) Evolution in the Myrtaceae - evidence from inflorescence structure. Proc. Linn. Soc. New South Wales 102: 157-256.

Brown, R. (1810) Prodromus Florae Novae Hollandiae.

Brown, W.V. (1975) Variations in anatomy, associations, and origins of Kranz tissue. Amer. J. Bot. 62: 395-402.

Burbidge, N.T. (1946) Morphology and anatomy of the Western Australian species of Triodia R. Br. II. Internal anatomy of leaves. Trans. Roy. Soc. South Australia 70: 221-234.

Burbidge, N.T. (1953) The genus Triodia R. Br. (Gramineae). Austral. J. Bot. 1: 121-184.

Burbidge, N.T. (1959) Notes on plants and plant habitats observed in the Abydos-Woodstock area, Pilbara district, Western Australia. CSIRO Division of Plant Industry Technical Paper no. 12.

Burbidge, N.T. (1960) The phytogeography of the Australian region. Austral. J. Bot. 8: 75-212.

Burbidge, N.T., \& Gray, M. (1970) Flora of the Australian Capital Territory (A.N.U. Press: Canberra).

Carolin, R.C., Jacobs, S.W.L., \& Vesk, M. (1977) The ultrastructure of Kranz cells in the family Cyperaceae. Bot. Gaz. 138: 413-419.

Clarke, C.B. (1884) On the Indian species of Cyperus; with remarks on some others that specially illustrate the subdivisions of the genus. J. Linn. Soc., Bot. 21: 1-202.

Clarke, C.B. (1908) New genera and species of Cyperaceae. Kew Bull. Misc. Inform. Add. Ser. 8: $1-196$.

Clarke, C.B. (1909) Illustrations of Cyperaceae (Williams \& Norgate: London).

Cronquist, A. (1977) On the taxonomic significance of secondary metabolites in angiosperms Pl. Syst. Evol., Suppl. 1: 179-189.

Cunningham, G.M., Mulham, W.E., Milthorpe, P.L., \& Leigh, J.H. (1981) Plants of western New South Wales (Govt Printer: Sydney).

Dell, B., \& McComb, A.J. (1978) Plant resins - their formation, secretion and possible functions. Adv. Bot. Research 6: 277-316.

Denton, M.F. (1978) A taxonomic treatment of the Luzulae group of Cyperus. Contr. Univ. Michigan Herb. 11: 196-271. 
Denton, M.F. (1983) Anatomical studies of the Luzulae group of Cyperus (Cyperaceae). Syst. Bot. 8: 250-262.

Dilcher, D.L. (1974) Approaches to the identification of angiosperm leaf remains. Bot. Rev. 40: 1-157.

Domin, K. (1915) Beiträge zur Flora und Pflanzengeographie Australiens, Abteilung 2 Embryophyta siphonogama, pars i: Gymnospermae, Monocotyledonae. Biblioth. Bot. 20(85): 243-551.

Dovey, L.G. (1935) Notes on the sedges (family Cyperaceae) found in the Bottle Creek section of the Baffle Creek Catchment Area, Port Curtis district. Queensland Naturalist 9: 90-92.

Druyts-Voets, E. (1970) Types van stengel- en bladstrukturen in het genus Cyperus L. Natuurw. Tijdschr. 52: 28-49.

Eardley, C.M. (1946) The Simpson Desert expedition, 1939 - Scientific reports: No. 7, Botany part I: Catalogue of plants. Trans. Roy. Soc. South Australia 70: 145-174.

Edgar, E. (1964) The leafless species of Juncus in New Zealand. New Zealand J. Bot. 2: 177-204. Edwards, P.I. (1981) The journal of Peter Good. Bull. Brit. Mus. (Nat. Hist.) Hist. Ser. vol. 9.

Eliasson, V. (1965) Studies in Galapagos plants. II Cyperales. Svensk Bot. Tidskr. 59: 469-491.

Erickson, R. (1969) The Drummonds of Hawthornden (Lamb Paterson: Osborne Park).

Ewart, A.J. (1931) Flora of Victoria (Melbourne U.P.: Melbourne).

Ewart, A.J., \& Davies, O.B. (1917) The Flora of the Northern Territory (McCarron, Bird \& Co.: Melbourne).

Federowicz, M.F. (1962) The significance of the achene and stoma in the status of Eucyperus and Mariscus (Cyperaceae) based on the studies of plastic replicas. Catholic Univ. America Biol. Studies No. 75.

Fitzgerald, W.V. (1918) The botany of the Kimberleys, north-west Australia. J. \& Proc. Roy. Soc. Western Australia 3: 102-24.

Flinders, M. (1814) A voyage to Terra Australis, vols. 1 \& 2, atlas.

Gardner, C.A. (1930) Enumeratio plantarum australiae occidentalis, part 1 (Govt Printer: Perth).

Gershenzon, J., \& Mabry, T.J. (1983) Secondary metabolites and the higher classification of angiosperms. Nord. J. Bot. 3: 5-34.

Goetghebeur, P. (1989) Studies in Cyperaceae 9. Problems in the lectotypification and infrageneric taxonomy of Cyperus L. Bull. Soc. Roy. Belg. 122: 103-114.

Gordon-Gray, K.D., van Laren, L., \& Bandu, V. (1978) Silica deposits in Rhynchospora species (Cyperaceae). Proc. Electron Microscopy Soc. Southern Africa 8: 83-84.

Gornall, R.J., \& Bohm, B.A. (1978) Angiosperm flavonoid evolution: a reappraisal. Syst. Bot. 3: 353-368.

Gornall, R.J., Bohm, B.A., \& Dahlgren, R. (1979) The distribution of flavonoids in the angiosperms. Bot. Notiser 132: 1-30.

Govindarajalu, E. (1974) The systematic anatomy of south Indian Cyperaceae: Cyperus L. subgen. Juncellus, Cyperus subgen. Mariscus and Lipocarpha R. Br. J. Linn. Soc., Bot. 68: 235266.

Haines, R.W., \& Lye, K.A. (1983) The sedges and rushes of East Africa (East African Nat. Hist. Soc.: Nairobi).

Harborne, J.B. (1980) New experimental approaches to plant chemosystematics. Pp. 39-70 in F.A. Bisby, J.G. Vaughan \& C.A. Wright (eds), Chemosystematics: principles and practice (Academic Press: London).

Harborne, J.B., \& Turner, B.L. (1984) Plant Chemosystematics (Academic Press: London).

Harborne, J.B., Williams, C.A., \& Wilson, K.L. (1982) Flavonoids in leaves and inflorescences of Australian Cyperus species. Phytochemistry 21: 2491-2507.

Harborne, J.B., Williams, C.A., \& Wilson, K.L. (1985) Flavonoids in leaves and inflorscences of Australian Cyperaceae. Phytochemistry 24: 751- 766.

Hattersley, P.W. (1983) The distribution of $\mathrm{C}_{3}$ and $\mathrm{C}_{4}$ grasses in Australia in relation to climate. Oecologia 57: 113-128.

Hattersley, P.W. (1984) Characterisation of $C_{4}$ type leaf anatomy in grasses (Poaceae). Mesophyll:bundle sheath area ratios. Ann. Bot. 53: 163-179.

Healy, A.J., \& Edgar, E. (1980) Flora of New Zealand, vol. 3 (Govt Printer: Wellington).

Holm, T. (1904) Studies in the Cyperaceae. XXIII The inflorescence of Cyperus in North America. Amer. J. Sci. 18: 301-307.

Hooker, J.D. (1858) Botany of the Antarctic voyage. Part III Flora Tasmaniae, vol. 2(6). 
Johnson, L.A.S., Briggs, B.G., \& Blaxell, D.F. (1981) Proposals to amend Articles 11, 32 and 34 of the Code. Taxon 30: 230-233.

Johnson, R.W. (1964) Ecology and control of brigalow in Queensland (Qld Dept. Primary Industries: Brisbane).

Kern, J.H. (1963) Flora Malesiana Precursores XXXII: Some new Cyperaceae. Blumea 12: 23-30.

Kern, J.H. (1974) Cyperaceae [Part 1]. Flora Malesiana ser. 1, vol. 7(3): 435-753.

Krasan, F. (1864) Erläuterungen zum Verständniss der Spirre (anthela). Flora 47: 161-172.

Kükenthal, G. (1931) Cyperaceae novae vel minus cognițae X. Feddes Repert. Spec. Nov. Regni Veg. 29: 187-202.

Kükenthal, G. (1935-36) Cypereae. In A. Engler, Das Pflanzenreich IV 20 Heft 101.

Kükenthal, G. (1940a) Neue Cyperaceen aus dem malayischen und papuanischen Gebiet I. Bull. Jard. Bot. Buitenzorg ser. 3, 16: 300-323.

Kükenthal, G. (1940b) Neue Cyperaceen aus Neuguinea. Bot. Jahrb. Syst. 70: 463-468.

Kunth, K.S. (1837) Enumeratio Plantarum, vol. 2.

Le Cohu, M.-C. (1973) Examen au microscope électronique à balayage, des cônes de silice chez les Cypéracées. Compt. Rend. Hebd. Séances Acad. Sci. Paris ser. D, 277: 1301-1303.

Lehmann, J.G.C. (1846) Plantae Preissianae, vol. 2, part 1.

Leigh, J., Boden, R., \& Briggs, J. (1984) Extinct and endangered plants of Australia (Macmillan: Melbourne/Sydney).

Levin, D.A. (1976) The chemical defenses of plants to pathogens and herbivores. Ann. Rev. Ecol. Syst. 7: 121-159.

Maiden, J.H., \& Betche, E. (1916) A census of New South Wales plants (Govt Printer: Sydney).

Marcks, B.G. (1974) Preliminary reports on the flora of Wisconsin No. 66. Cyperaceae II sedge family II. The genus Cyperus - the umbrella sedges. Trans. Wisconsin Acad. Sci. 62: 261-284.

Marek, S. (1958) A study on the anatomy of fruits of European genera in the subfamilies Scirpoideae Pax, Rhynchosporoideae Aschers. et Graebner and some genera of Caricoideae Pax. Monogr. Bot. 6: 151-177.

Mathis, C. (1966) Comparative biochemistry of hydroxyquinones. Pp. 245-270 in T. Swain (ed.), Comparative Phytochemistry (Academic Press: London).

Menu, M.A. (1908) Etude anatomique du fruit et de la graine des Cypéracées (Thesis, Univ. Paris, Ecole Supérieure de Pharmacie: Paris).

Metcalfe, C.R. (1971) Anatomy of the mnocotyledons. V. Cyperaceae (Oxford U.P.: London).

Moore, C., \& Betche, E. (1893) Handbook of the flora of New South Wales.

Mueller, F. (1859) Fragmenta Phytographiae Australiae, vol. 1.

Mueller, F. (1874) Fragmenta Phytographiae Australiae, vol. 8.

Mueller, F. (1875) Fragmenta Phytographiae Australiae, vol. 9.

Mueller, F. (1886) Plants collected in Capricornic Western Australia, by H.S. King, Esq. Preprint of Proc. Roy. Soc. Victoria 23: 49-57 (1887).

Mueller, F., \& Tate, R. (1890) List of plants collected during Mr Tietkens' expedition into Central Australia, 1889. Trans. \& Proc. Roy. Soc. South Australia 13: 94-106.

Piperno, D.R. (1989) The occurrence of phytoliths in the reproductive structures of selected tropical angiosperms and their significance in tropical paleoecology, paleoethnobotany and systematics. Rev. Palaeobot. Palynol. 61: 147-173.

Poiret, J.L.M. (1817) Encyclopédie Méthodique Botanique, Suppl. 5.

Probst, R. (1949) Wolladventivflora Mitteleuropas (Solothurn).

Ragonese, A.M., Guaglianone, E.R., \& De Strittmatter C.D. (1984) Desarrollo del pericarpio con cuerpos de silice de dos especies de Rhynchospora Vahl (Cyperaceae). Darwiniana 25: 27-41.

Raven, J.A. (1983) The transport and function of silicon in plants. Biol. Rev. 58: 179-207.

Ray, T.B., \& Black, C.C. (1979) The $\mathrm{C}_{4}$ pathway and its regulation. Pp. 77-101 in M. Gibbs \& E. Latzko (eds), Photosynthesis II - Photosynthetic carbon metabolism and related processes (SpringerVerlag: Berlin).

Raynal, J. (1971) Quelques notes morphologiques sur les Cypéracées. Mitt. Bot. Staatssamml. München 10: 589-603.

Raynal, J. (1972) Répartition et évolution des modes de photosynthèse chez les Cypéracées. Compt. Rend. Hebd. Séances Acad. Sci. Paris, ser. D, 275: 2231-2234.

Raynal, J. (1973) Notes Cypérologiques: 19. Contribution à la classification de la sous-famille des Cyperoideae. Adansonia ser. 2, 13: 145-171. 
Rodway, L. (1903) The Tasmanian fora (Govt Printer: Hobart).

Ryves, T.B. (1976) Notes on some wool-alien Cyperaceae from Blackmoor, N. Hants. Watsonia 11: $69-70$.

Sangster, A.G., \& Parry, D.W. (1981) Ultrastructure of silica deposits in higher plants. Pp. 383-407 in T.L. Simpson \& B.E. Volcani (eds), Silicon and siliceous structures in biological systems (Springer-Verlag: New York).

Schuyler, A.E. (1971) Scanning electron microscopy of achene epidermis in species of Scirpus (Cyperaceae) and related genera. Proc. Acad. Nat. Sci. Philadelphia 123: 29-52.

Sharpe, P. (1989) Cyperaceae. Pp. 277-355 in T.D. Stanley \& E.M. Ross, Flora of south-eastern Queensland, vol. 3 (Qld Dept Primary Industries: Brisbane).

Snow, M. (1955) Spirodistichy re-interpreted. Trans. Roy. Soc. London, ser. B, Biol. Sci., 239: 45-88.

Société française des Chrysanthémistes (1905) Répertoire de couleurs pour aider à la détermination des couleurs des fleurs, des feuillages et des fruits (Oberthur: Paris).

Specht, R.L., \& Mountford, C.P. (1958) Records of the American-Australian scientific expedition to Arnhem Land; vol. 3, Botany and plant ecology (Melbourne U.P.: Melbourne).

Sprengel, K.P.J. (1824) Systema vegetabilium, edn 16, vol. 1.

Stearn, W.T. (1973) Botanical Latin, edn 2 (David \& Charles: Newton Abbot).

Steudel, E.G. (1854) Synopsis plantarum glumacearum, vol. 2, part 1.

Stuessy, T.F., \& Crawford, D.J. (1983) Flavonoids and phylogenetic reconstruction. Pl. Syst. Evol. 143: 83-107.

Takeda, T., Ueno, O., Samejima, M., \& Ohtani, T. (1985) An investigation for the occurrence of $\mathrm{C}_{4}$ photosynthesis in the Cyperaceae from Australia. Bot. Mag. Tokyo 98: 393-411.

Tate, R. (1890) Handbook to the flora of extratropical South Australia.

Tate, R. (1896) Horn scientific expedition to central Australia. Part III. Section 2: Botany.

Toivonen, H., \& Timonen, T. (1976) Perigynium and achene epidermis in some species of Carex, subg. Vignea (Cyperaceae), studied by scanning electron microscopy. Ann. Bot. Fennici 13: $49-59$.

Troll, W. (1964) Die Infloreszenzen (G. Fischer Verlag: Stuttgart).

Tucker, G.C. (1983) The taxonomy of Cyperus (Cyperaceae) in Costa Rica and Panama. Syst. Bot. Monogr. vol. 2.

Ueno, O., Takeda, T., \& Maeda, E. (1988) Leaf ultrastructure of $C_{4}$ species possessing different Kranz anatomical types in the Cyperaceae. Bot. Mag. (Tokyo) 101: 141-152.

Walker, D. (1972) Bridge and Barrier: the natural and cultural history of Torres Strait. Research School Pacific Studies Public. BG/3. (Austral. Nat. Univ.: Canberra).

Weberling, F. (1989) Morphology of flowers and inflorescences [transl. by R.J. Pankhurst] (Cambridge Univ. Press: Cambridge).

Williams, C.A., \& Harborne, J.B. (1975) Luteolin and daphnetin derivatives in the Juncaceae and their systematic significance. Biochem. Syst. Ecol. 3: 181-190.

Willis, J.H. (1962) A handbook to plants in Victoria, edn 1, vol. 1 (Melbourne U.P.: Melbourne).

Willis, J.H. (1970) A handbook to plants in Victoria edn 2, vol. 1 (Melbourne U.P.: Melbourne).

Wilson, K.L. (1980) Notes on some Australian species of Cyperaceae. Telopea 1: 457-467.

Wilson, K.L. (1981a) Cyperus. Pp. 502-509 in J.P. Jessop (ed.), Flora of central Australia (Reed: Sydney).

Wilson, K.L. (1981b) Revision of the genus Mesomelaena (Cyperaceae). Telopea 2: 181-195.

Wilson, K.L. (1987) Cyperus. Pp. 1123-1140 in N.C.W. Beadle, Students flora of north eastern New South Wales, part 6 (Univ. New England: Armidale).

Wollenweber, E. \& Dietz, V.H. (1981) Occurrence and distribution of free flavonoid aglycones in plants. Phytochemistry 20: 869-932. 


\section{Index}

New names and combinations are printed in boldface, synonyms are printed in italics.

$\begin{aligned} & \text { Cyperus subgen. Anosporum } \\ & \text { Cyperus sect. Glomerati } \\ & \text { sect. Glutinosi } \\ & \text { sect. Ixiocarpi } \\ & \text { sect. Laxiglumi } \\ & \text { sect. Multiflori }\end{aligned}$.
sect. Pennati
sect. Phleoidei
sect. Pinnati
sect. Pseudomariscus

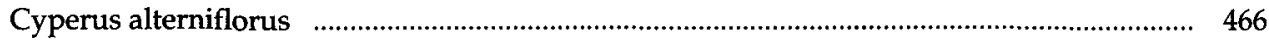

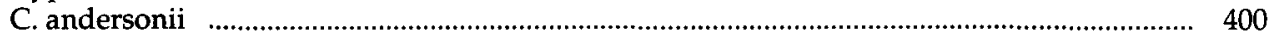

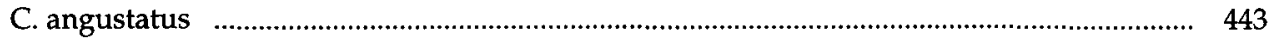

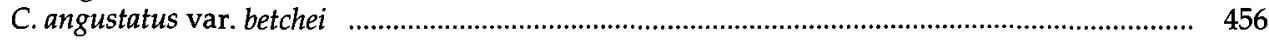

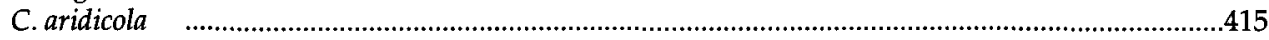

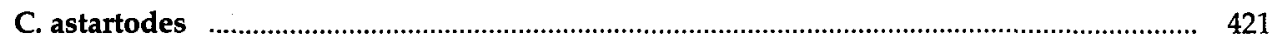

C. baoulensis

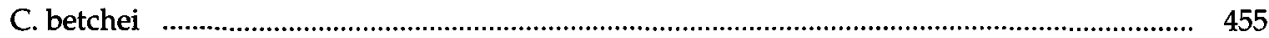

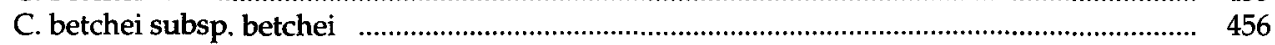

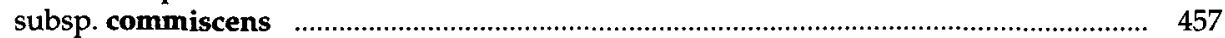

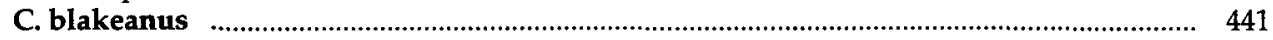

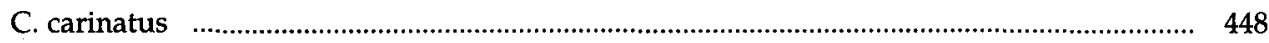

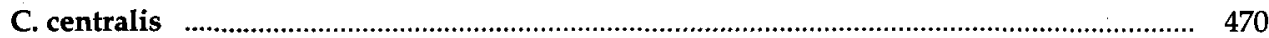

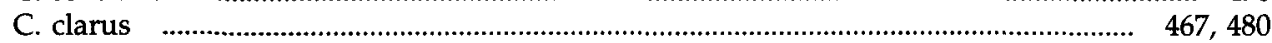

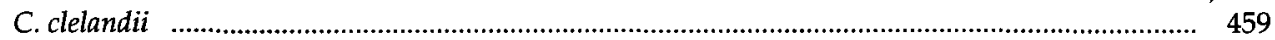

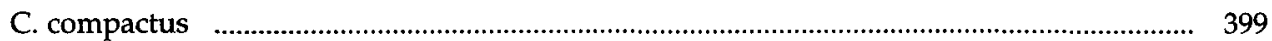

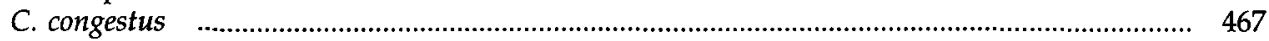

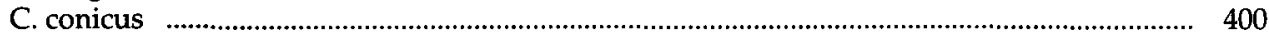

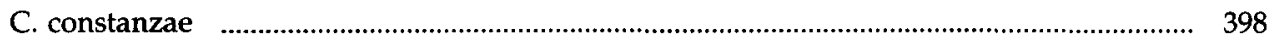

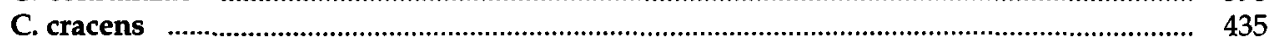

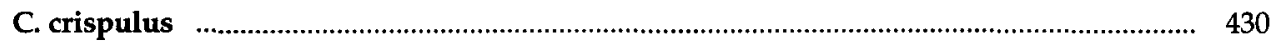

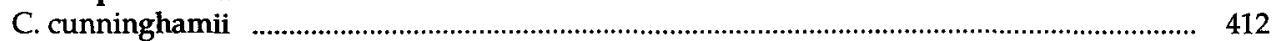

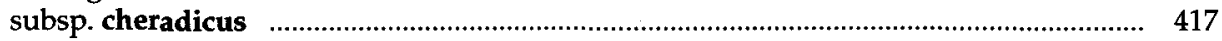

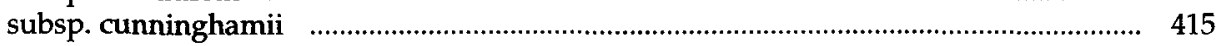

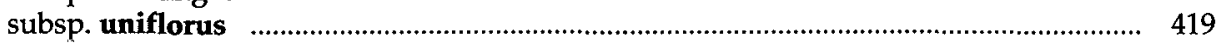

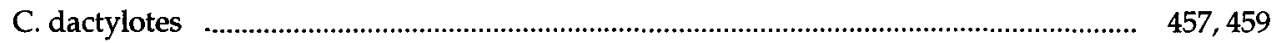

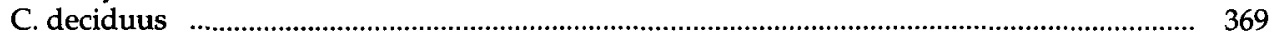

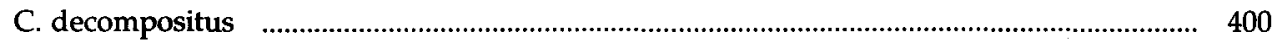

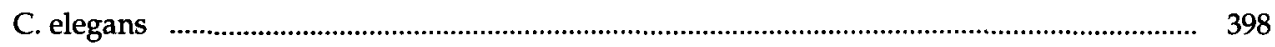

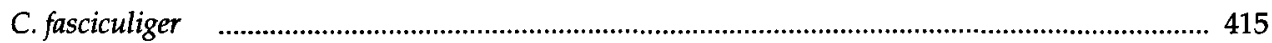

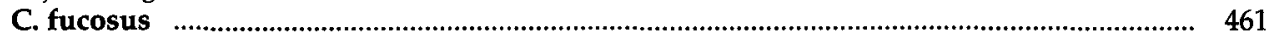




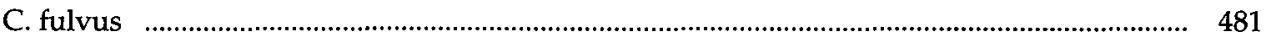

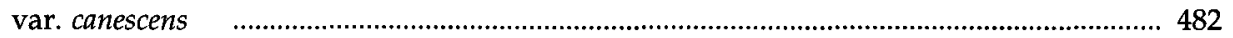

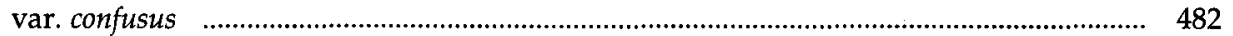

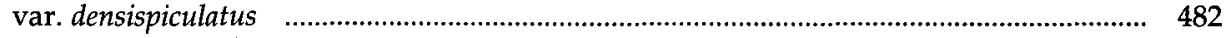

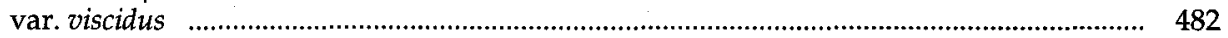

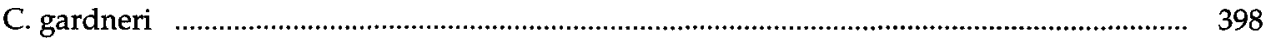

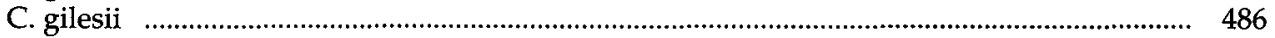

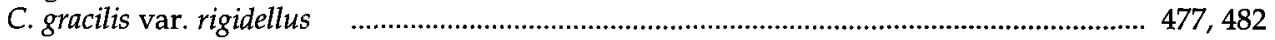

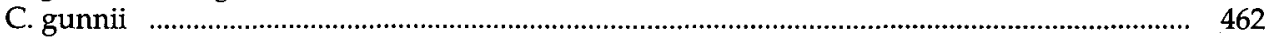

subsp. gunnii .................................................................................................................. 464

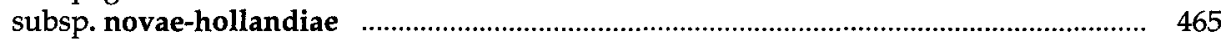

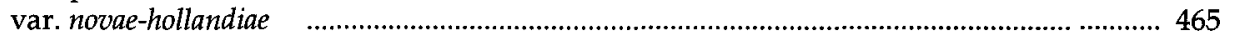

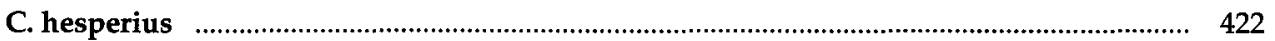

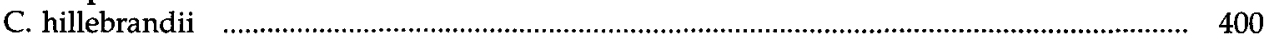

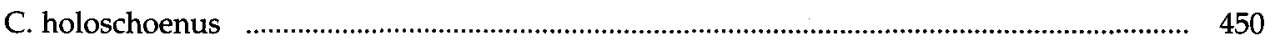

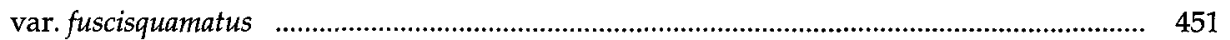

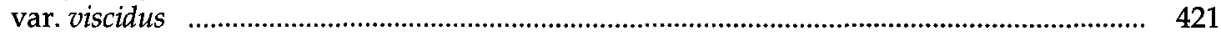

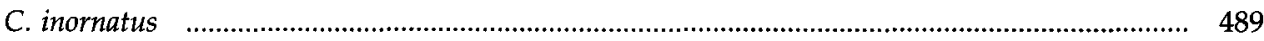

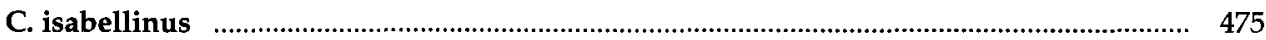

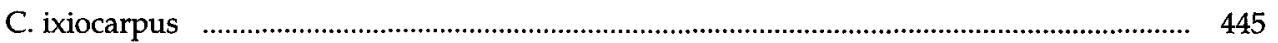

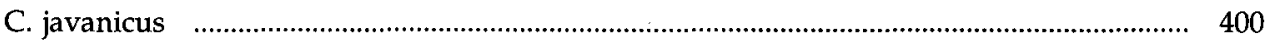

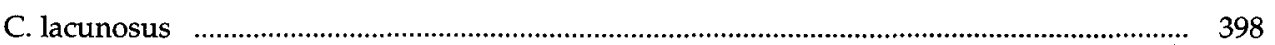

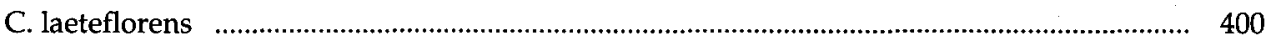

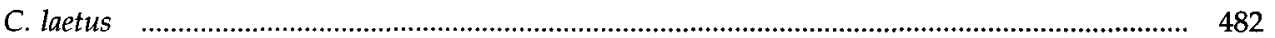

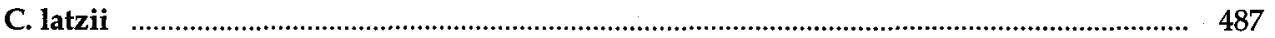

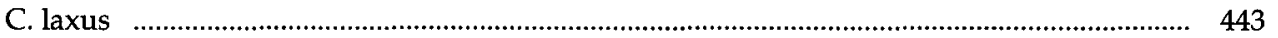

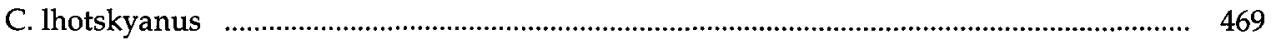

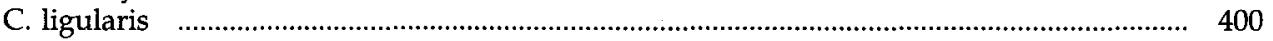

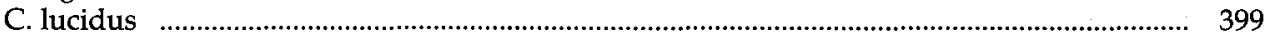

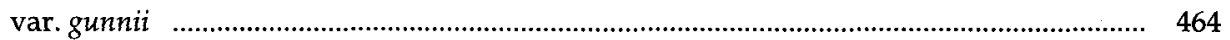

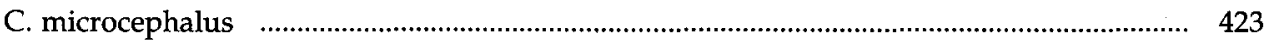

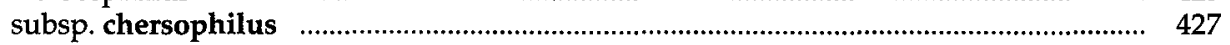

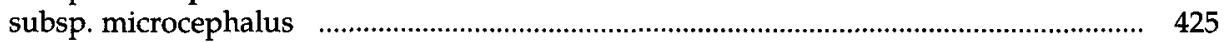

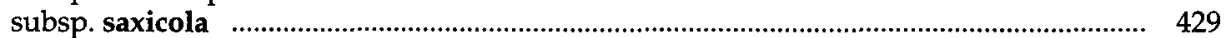

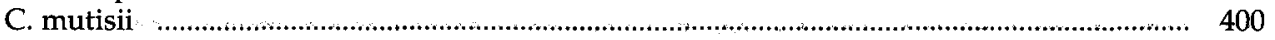

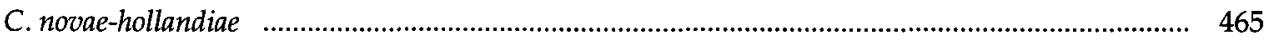

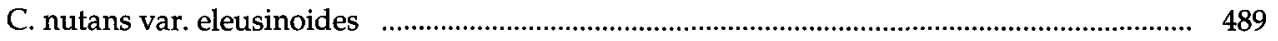

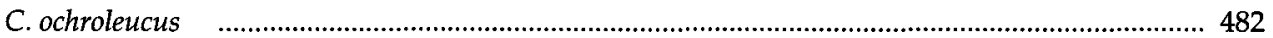

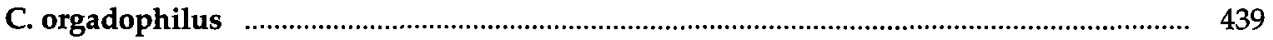

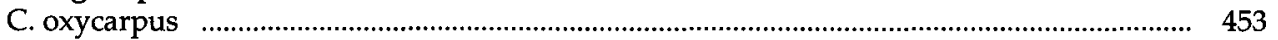

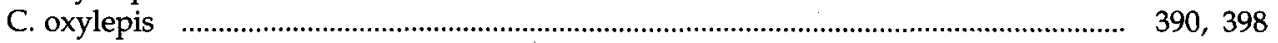

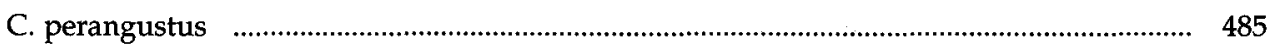

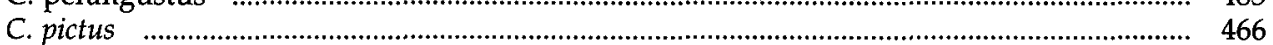

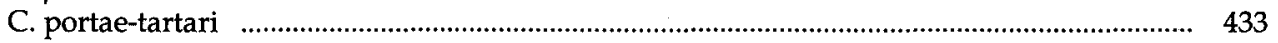

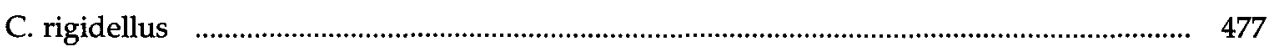

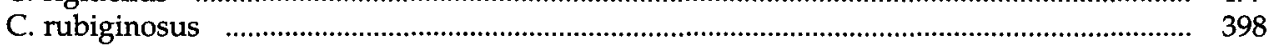

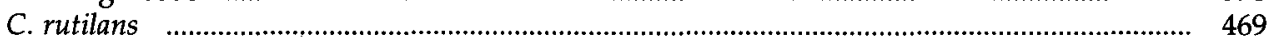

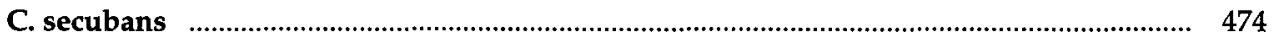




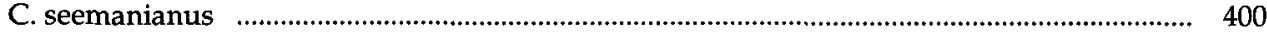

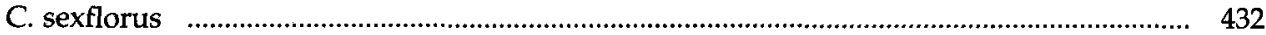

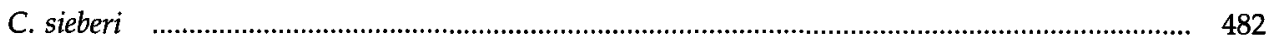

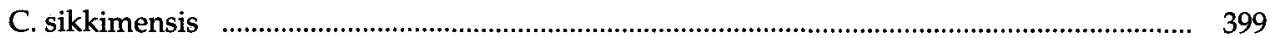

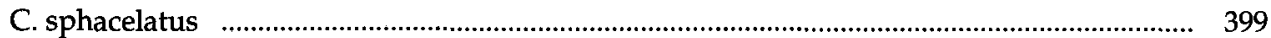

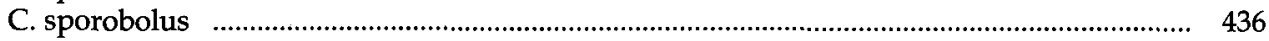

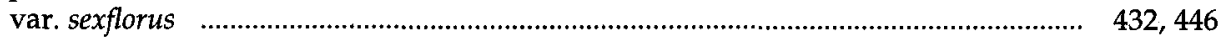

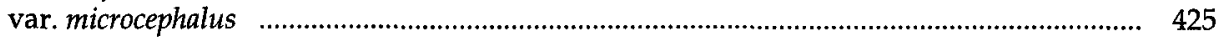

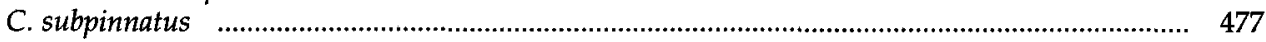

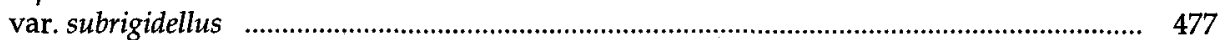

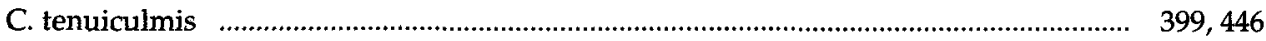

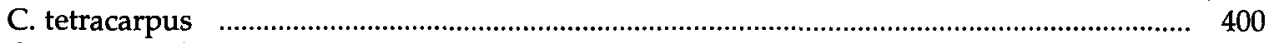

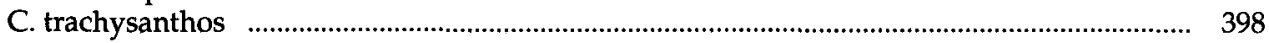

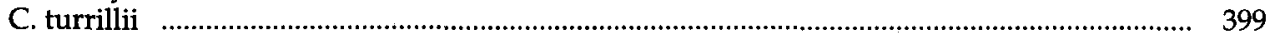

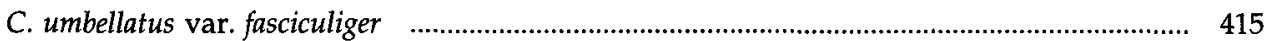

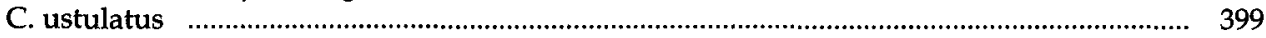

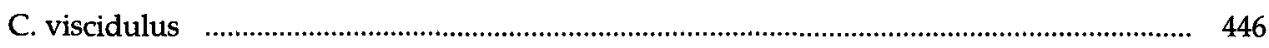

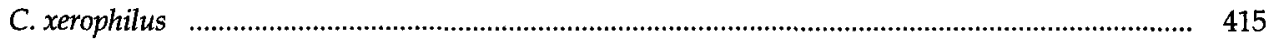

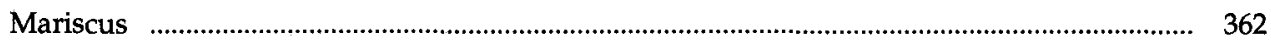

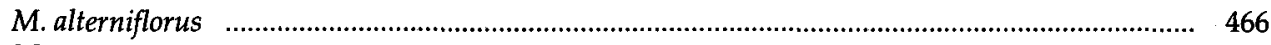

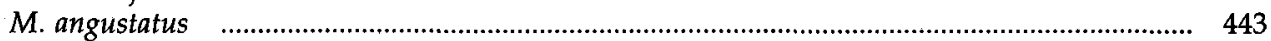

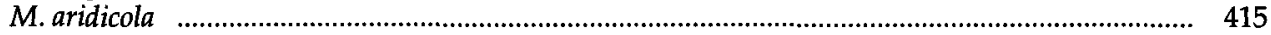

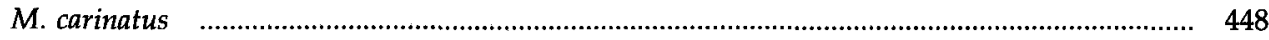

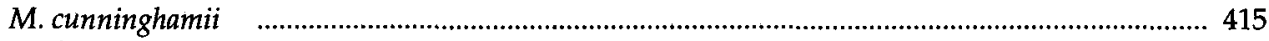

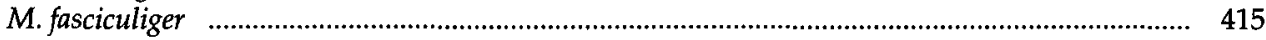

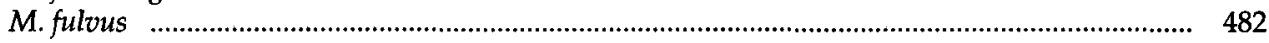

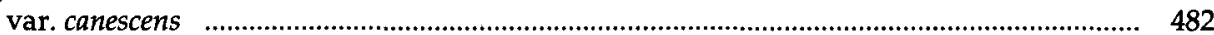

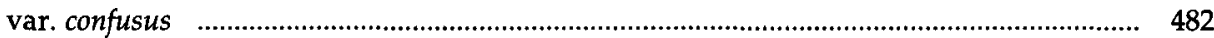

var. densispiculatus $\quad$.......................................................................................................... 482

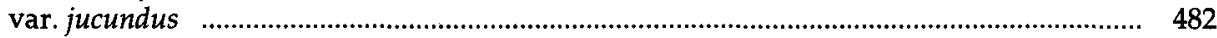

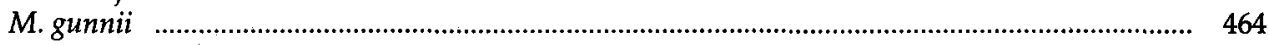

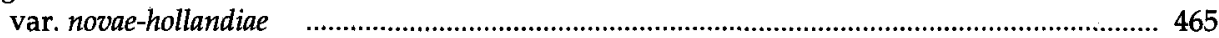

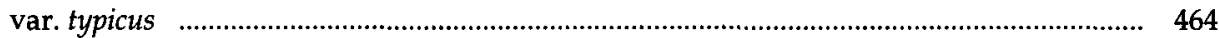

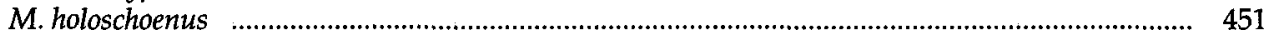

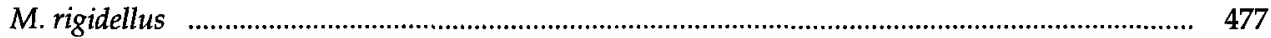

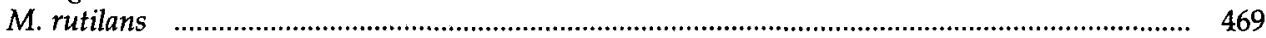

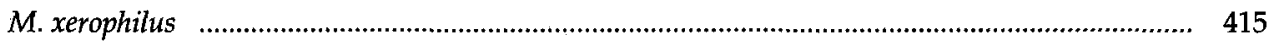

Manuscript received 9 May 1990

Manuscript accepted 14 March 1991 